Girlane Almeida Bondan 


\title{
O ENSINO DE EMPREENDEDORISMO NOS CURSOS SUPERIORES DE TECNOLOGIA DO IFSC CÂMPUS FLORIANÓPOLIS - CONTINENTE
}

\author{
Girlane Almeida Bondan
}

Dissertação apresentada ao Programa de PósGraduação em Educação - modalidade profissional da Universidade de Brasília, como parte dos requisitos para obtenção do título de Mestre em Educação na área de Políticas Públicas e Gestão da Educação Profissional e Tecnológica.

Orientador: Prof. Dr. Remi Castioni 
Ficha catalográfica elaborada automaticamente, com os dados fornecidos pelo(a) autor(a)

Almeida Bondan, Girlane

O Ensino de Empreendedorismo nos Cursos

Superiores de Tecnologia do IFSC Câmpus Florianópolis Continente / Girlane Almeida Bondan; orientador Remi Castioni. -- Brasília, 2016. $170 \mathrm{p}$.

Dissertação (Mestrado - Mestrado Profissional em Educação) -- Universidade de Brasília, 2016.

1. Empreendedorismo. 2. Ensino de

Empreendedorismo. 3. Ensino por Competências . 4. Institutos Federais de Educação, Ciência e

Tecnologia. I. Castioni, Remi, orient. II. Título. 


\section{GIRLANE ALMEIDA BONDAN}

O ENSINO DE EMPREENDEDORISMO NOS CURSOS SUPERIORES DE TECNOLOGIA DO IFSC CÂMPUS FLORIANÓPOLIS - CONTINENTE

Dissertação apresentada ao Programa de Pós-Graduação em Educação Profissional da Faculdade de Educação da Universidade de Brasília, como parte dos requisitos para obtenção do título de Mestre em Educação. Àrea de concentração: Políticas Públicas e Gestão da Educação Profissional e Tecnológica.

APROVADA EM: 20/05/2016.

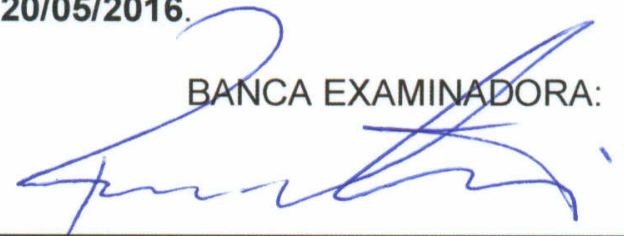

Prof. Dr. Remi Castioni (Faculdade de Educação/UnB) ORIENTADOR

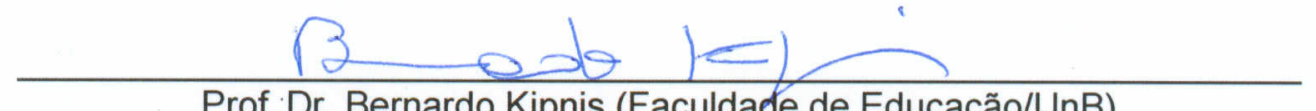

Prof. Dr. Bernardo Kipnis (Faculdade de Educação/UnB) EXAMINADOR(A) INTERNO(A)

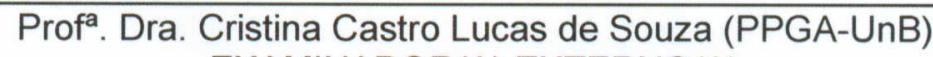
EXAMINADOR(A) EXTERNO(A)

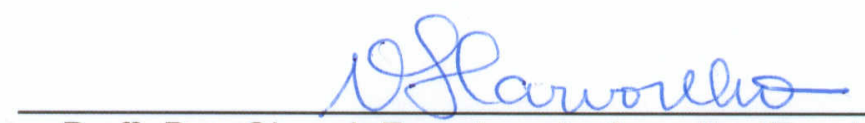

Profa $^{a}$. Dra. Olgamir Francisco de Carvalho (Faculdade de Educação/UnB) SUPLENTE

Brasília, 20 de maio de 2016. 


\section{AGRADECIMENTOS}

Agradeço a Deus e aos meus antepassados por terem me permitido chegar até aqui.

Agradeço aos meus pais por tudo, por me ensinarem o valor das pessoas, do trabalho e da humildade.

Às minhas irmãs e sobrinha, minhas almas gêmeas sangue, de alma e coração.

Agradeço aos meus queridos amigos, sem os quais eu não teria razão de existir, pela ajuda, amizade, apoio, motivação e pela compreensão com as minhas ausências provocadas pela dedicação à pesquisa.

Agradeço ao IFSC eternamente, por poder fazer parte dessa história.

Agradeço aos meus queridos alunos, que são minha principal fonte de motivação e inspiração para a vida acadêmica.

Agradeço ao meu chefe que posso chamar de amigo, Prof. Luiz Otávio Cabral, pela liderança através do exemplo, paciência e apoio.

Aos meus colegas de mestrado, especialmente os colineiros e colinetes que me enchem os olhos de lágrimas só de lembrar dos maravilhosos momentos que passamos de companheirismo, descontração e amor.

Ao meu querido orientador professor Remi, pelas ótimas aulas e pela inspiração, paciência, fazendo sempre mais pelos seus alunos.

Aos professores Olgamir Carvalho, Albertina Mitjáns e Bernardo Kipnis pela motivação e pela eterna inspiração e exemplo.

A todos os entrevistados que gentilmente compartilharam seu tempo e conhecimento em favor da pesquisa.

A todos aqueles que movem o mundo com honestidade, pensando e se doando àqueles que mais necessitam, e aos "desvalidos da sorte" todo o meu carinho, dedicação e amor.

Ao ex-presidente Lula, por ter oportunizado ingressar no mundo maravilhoso e desafiador da educação profissional e tecnológica. Gratidão. 


\section{RESUMO}

Os cursos superiores de Gastronomia e Hotelaria, oferecidos no Instituto Federal de Educação, Ciência e Tecnologia de Santa Catarina - câmpus Florianópolis-Continente, possuem componentes curriculares na área de empreendedorismo, que objetivam fortalecer a formação dos alunos com uma ferramenta considerada de grande utilidade para sua atuação no mundo do trabalho. A percepção desse fato fomentou 0 interesse em elaborar esta pesquisa, visando esclarecer sobre a importância do empreendedorismo na formação dos alunos que frequentam os cursos superiores do IFSC - câmpus Florianópolis-Continente. Para isso, foi proposta uma pesquisa de abordagem qualitativa, do tipo estudo de caso, com objetivo geral de investigar o entendimento dos docentes e discentes dos cursos superiores de tecnologia ofertados na instituição, foco do estudo, sobre a contribuição do componente curricular de Empreendedorismo para a intenção em empreender. Os resultados indicaram a necessidade de práticas voltadas ao ensino do empreendedorismo, que estimulem os alunos a empreender, considerando, principalmente, as características de cada um dos cursos estudados. Pretende-se, com esta análise, contribuir para novas práticas e encaminhar estudos futuros sobre a temática.

Palavras-chaves: Empreendedorismo; Ensino de Empreendedorismo; Ensino por Competências; Institutos Federais de Educação, Ciência e Tecnologia. 


\begin{abstract}
The upper courses of Gastronomy and Hospitality offered at the Federal Institute of Education, Science and Technology - Florianópolis-Continent campus, have curriculum components in the area of entrepreneurship, aiming to strengthen the training of students with a considered tool very useful for its operations in the world work. The realization of this fact stimulated the interest in developing this research, aiming to clarify the importance of entrepreneurship in the education of students attending university courses at the Federal Institute of Education, Science and Technology - FlorianópolisContinent campus. For this, we propose a qualitative research, the case study type, with overall objective to investigate the understanding of teachers and students of higher education technology offered in the institution, focus the study on the contribution of the curricular component of Entrepreneurship for the intention to undertake. The results indicated the need for practices aimed at entrepreneurship education, to encourage students to undertake, considering mainly the characteristics of each of the courses studied. It is intended with this analysis, contribute to new practices and submit further studies on the subject.
\end{abstract}

Keywords: Entrepreneurship; Entrepreneurship Education; Teaching Skills; Federal Institutes. 


\section{LISTA DE QUADROS}

Quadro 1 - Conceitos de empreendedorismo e empreendedor.

Quadro 2 - Pesquisas realizadas, utilizando a tipologia de competências empreendedoras. 32

Quadro 3 - Conceito de competências na visão americana............................ 35

Quadro 4 - Conceito de competências na visão francesa............................... 35

Quadro 5 - Conceito de competências.............................................................. 36

Quadro 6 - Conceito de competências, a partir de Bittencourt (2002)............ 37

Quadro 7 - Glossário RDP........................................................................... 44 


\section{LISTA DE TABELAS}

Tabela 1 - Estudantes dos cursos de Gastronomia e Hotelaria.................... 49 


\section{LISTA DE FIGURAS}

Figura 1 - Distribuição dos campi do IFSC 


\section{LISTA DE SIGLAS}

CEFET-SC - Centro Federal de Educação Tecnológica de Santa Catarina CERFEAD - Centro de Referência e Formação em EaD

CNE - Conselho Nacional de Educação

EJA - Educação de Jovens e Adultos Integrada à Educação Profissional EPT - Educação Profissional e Tecnológica

IES - Instituto de Educação Superior

IFSC - Instituto Federal de Educação, Ciência e Tecnologia de Santa Catarina

iLABEM - Laboratório de Empreendedorismo

MEC - Ministério da Educação

MEI - Microempreendedor Individual

PDI - Plano de Desenvolvimento Institucional

PPC - Projetos Pedagógicos dos Cursos

RDP - Regulamento Didático-Pedagógico

SBA - Small Business Administration

$\mathrm{SBI}$ - Small Business Institute Program

SEBRAE - Serviço Brasileiro de Apoio às Micro e Pequenas Empresas

UNESCO - Organização das Nações Unidas para a educação, a ciência e a cultura 


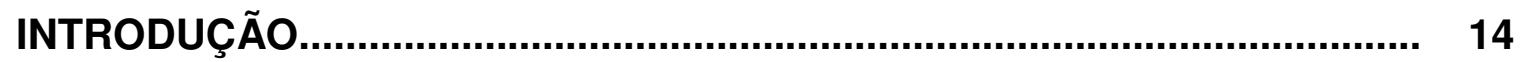

Discussão do problema e objetivos da pesquisa........................................ 16

Procedimentos metodológicos............................................................. 18

Estrutura da dissertação....................................................................... 18

CAPÍTULO 1 - O ENSINO DE EMPREENDEDORISMO E A EDUCAÇÃO POR COMPETÊNCIAS...................................................................... 20

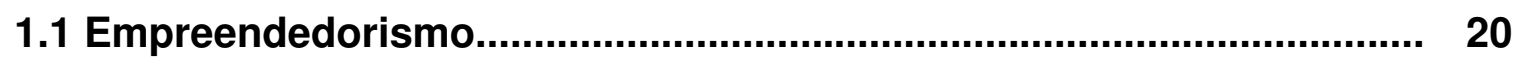

1.1.1 A origem e o significado dos termos empreendedorismo e empreendedor.......................................................................... 25

1.1.2 Formação empreendedora......................................................... 26

1.1.3.1 Histórico da formação empreendedora............................................... 29

1.2 Competência empreendedora e educação............................................ 33

1.2 A competência no contexto educacional.................................................... 35

1.2.1 Conceitos de competência na visão de outros países e do

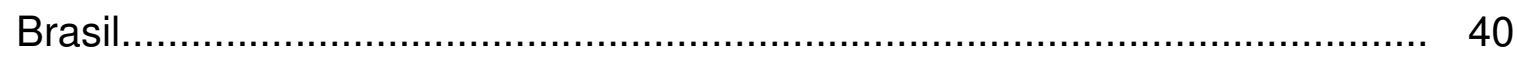

CAPÍTULO 2 - O ENSINO DE EMPREENDEDORISMO NO IFSC................... 41

2.10 currículo por competências................................................................ 41

2.1.1 Competências no âmbito do IFSC.................................................... 43

2.1.1.1 Plano de Desenvolvimento Institucional do IFSC- PDI........................ 44

2.1.1.2 Regulamento Didático-Pedagógico do IFSC....................................... 47

CAPÍTULO 3 - ABORDAGEM METODOLÓGICA........................................ 47

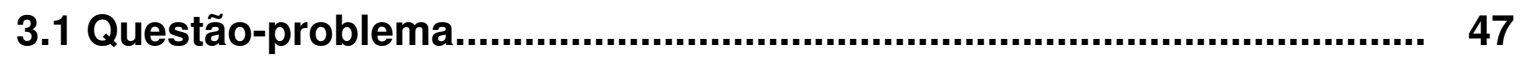

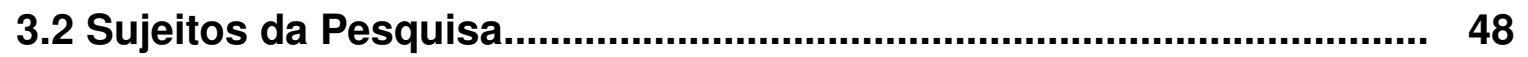

3.3 Amostra

3.4 Instrumento de coleta de dados....................................................... 49

3.5 Coleta dos dados................................................................... 49

3.6 Análise dos dados................................................................... 50

3.7 Aspectos éticos............................................................................ 50

CAPÍTULO 4 - COMO DOCENTES E DISCENTES COMPREENDEM A FORMAÇÃO EM EMPREENDEDORISMO NO IFSC................................... 51

4.1 Caracterização dos sujeitos............................................................... 51 
4.2 O olhar discente sobre suas experiências com empreendedorismo.... 53

4.3 O olhar docente sobre as experiências oferecidas aos alunos no........ 64 componente curricular de empreendedorismo......................................... 69

4.4 Análise Documental: PPCs e Planos de Ensino................................... 69

CAPÍTULO 5 - PRODUTO TÉCNICO......................................................... 71

5.1 Laboratório Virtual de Empreendedorismo iLABEM: Um espaço para fomento de iniciativas empreendedoras.................................................... 71

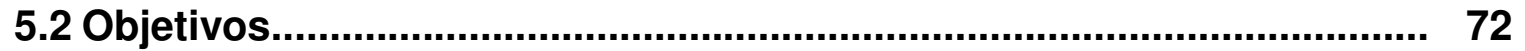

5.2 .1 Objetivo Geral................................................................... 72

5.2 .2 Objetivos Específicos...................................................... 72

5.3 Metodologia....................................................................................... 73

5.4 Resultados Esperados................................................................... 73

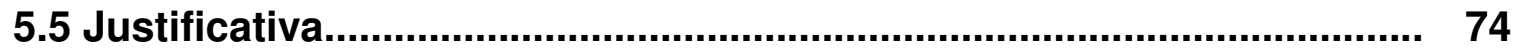

CONSIDERAÇÕES FINAIS.................................................................... 75

REFERÊNCIAS BIBLIOGRÁFICAS........................................................ 79

APÊNDICE A - Questionário docente ................................................. 82

APÊNDICE B - Questionário discente.............................................. 83

ANEXO A - PPC Curso Superior de Tecnologia em Gastronomia................ 84

ANEXO B - PPC Curso Superior de Tecnologia em Hotelaria....................... 127 


\section{INTRODUÇÃO}

Os Institutos Federais de Educação, Ciência e Tecnologia foram criados a partir do Decreto 6.095, de 24 de abril de 2007, e da Lei 11.892, de 29 de dezembro de 2008. Tal ordenamento jurídico instituiu a Rede Federal de Educação Profissional, Científica e Tecnológica, estabelecendo a criação de 38 Institutos Federais, dos quais dois estão no estado de Santa Catarina.

O Instituto Federal de Educação, Ciência e Tecnologia de Santa Catarina (IFSC) foi implantado a partir da estrutura preexistente do Centro Federal de Educação Tecnológica de Santa Catarina (CEFET-SC). O IFSC conta, atualmente, com 22 campi $^{1}$ em funcionamento, distribuídos pelo território catarinense, conforme representado na Figura 1, a seguir.

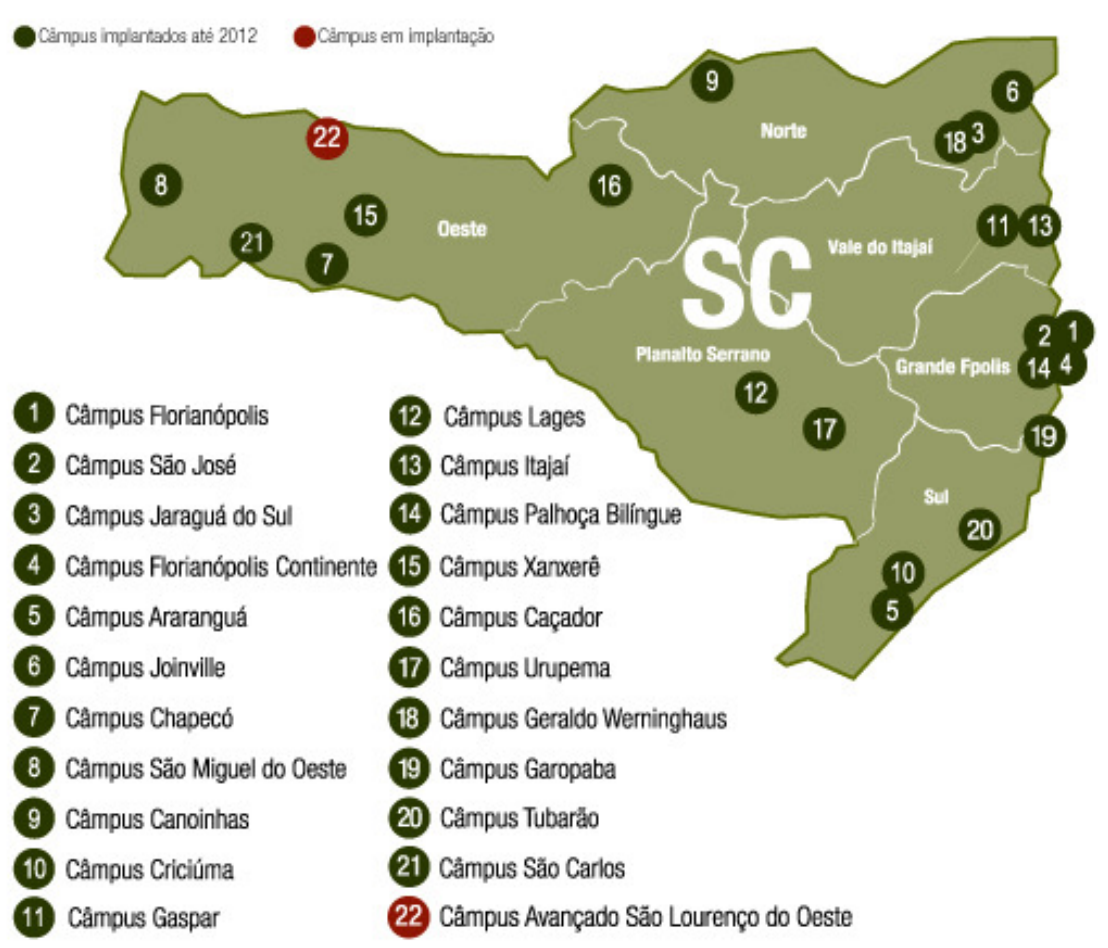

Figura 1 - Distribuição dos campi do IFSC

Fonte: site IFSC

\footnotetext{
${ }^{1}$ A Academia Brasileira de Letras (ABL) recomenda a utilização do singular "campus" e do plural "campi" nos textos em que devam prevalecer estes vocábulos como integrantes de léxico de terminologia científica.
} 
As alterações do mundo do trabalho, decorrentes das "novas" dimensões da relação entre trabalho e educação, impõem desafios às instituições de educação profissional e tecnológica no Brasil (SOUZA e CASTIONI, 2012). Assim, a criação dos Institutos Federais, a partir das Escolas Técnicas e Agrotécnicas, marca uma mudança de perspectiva em relação à Educação Profissional e Tecnológica (EPT).

A inovação pretendida pela política pública declara a intencionalidade de alcançar a superação da dualidade histórica entre "formação específica versus formação geral", "educação humanista versus educação profissional" e, sobretudo, da relação entre Educação Básica e formação técnica. Nesse sentido, a proposta defende a integração entre os conhecimentos específicos e o desenvolvimento da capacidade de investigação científica por meio de ações de ensino, pesquisa e extensão.

A pretensão dessa política foi, inicialmente, considerada ambiciosa e inovadora, demandando, assim, um considerável esforço dos agentes de implementação em todos os níveis institucionais. Quase cem anos se passaram e o número de institutos aumentou de aproximadamente 140 unidades para mais de 500 em 2016, distribuídas pelo território nacional.

Esses números foram consolidados com base no plano de expansão da Rede Federal de Educação Profissional, Científica e Tecnológica. Trata-se, sem dúvida, de um avanço expressivo, principalmente considerando o espaço temporal de menos de uma década. Os Institutos Federais representam uma proposta singular de organização e gestão no contexto histórico das políticas educacionais no Brasil.

Vários desafios foram impostos a essa nova estrutura institucional e precisaram ser superados: a ampliação do acesso à Educação Profissional de Nível Técnico; a graduação tecnológica, por meio de cursos superiores de tecnologia; os bacharelados; as licenciaturas; e a pós-graduação, além das atividades de pesquisa e extensão (SOUZA e CASTIONI, 2012).

Tudo isso ocorreu embasado nos fundamentos da lei de criação dos Institutos Federais, assim definidos: "Art. $2^{\circ}$ Os Institutos Federais são instituições de educação superior, básica e profissional, pluricurriculares e multicampi, especializados na oferta de educação profissional e tecnológica nas diferentes modalidades de ensino, com base na conjugação de conhecimentos técnicos e tecnológicos com as suas práticas pedagógicas" (BRASIL, 2008). 
A relevância que essa nova figura da EPT assumiu, na agenda da sociedade brasileira, trouxe, no seu interior, complexos desafios. Ao reunir em torno dos Institutos Federais uma variedade de instituições diversificadas, a nova institucionalidade recebeu importantes atribuições: atender ao ensino técnico de nível médio; ofertar graduações tecnológicas, bacharelados e licenciaturas; atender a Educação de Jovens e Adultos integrada à Educação Profissional - EJA; atuar em nível de pós-graduação com especializações, mestrados e doutorados; e, ainda, desenvolver pesquisa e extensão. Trata-se, ainda hoje, de um notável desafio de implementação em realidades diversas, visto que, em decorrência do processo de expansão, boa parte dessa estrutura foi criada em regiões que nunca tiveram perspectiva de contar com a oferta de cursos desse padrão.

$\mathrm{Na}$ época, um contingente significativo de servidores foi contratado e alocado em regiões longínquas, onde iniciaram a implantação dos campi, o que demandou grande esforço por parte das instituições, no direcionamento da construção da identidade dos Institutos Federais. Resumindo, deve-se ressaltar, a Lei 11.892/2008 inaugurou uma nova fase das instituições de EPT no Brasil.

\section{Discussão do problema e objetivos da pesquisa}

Para além das ofertas em todo o itinerário formativo da EPT, os Institutos foram concebidos para propiciar, dentro das atividades finalísticas, o fomento ao empreendedorismo. A lei de criação assim traz: "Art. 6옹 Institutos Federais têm por finalidades e características: [...] VIII - realizar e estimular a pesquisa aplicada, a produção cultural, o empreendedorismo, o cooperativismo e o desenvolvimento científico e tecnológico" (BRASIL, 2008, grifo nosso).

O IFSC, campus Florianópolis-Continente, foi incorporado, por meio do processo de federalização de uma escola privada, para atuar exclusivamente no eixo tecnológico em Hospitalidade e Lazer. Os cursos superiores oferecidos, Gastronomia 
e Hotelaria, atuam com componentes curriculares ${ }^{2}$ na área de empreendedorismo, objetivando a formação para o protagonismo no mundo do trabalho.

Os dois cursos são ofertas recentes, e as primeiras turmas serão diplomadas no ano de 2016. O tema Empreendedorismo, no campus, é alvo de entendimentos contraditórios, especialmente no meio docente e pedagógico. Grosso modo, há professores que defendem a abordagem da temática e outros que são contrários a ela. Estes últimos acreditam que a formação empreendedora mascara fragilidades do sistema capitalista, e os que a defendem acreditam na possibilidade de tornar as pessoas autônomas e prósperas, contribuindo com o avanço e a inovação na oferta de produtos e serviços na área de formação.

A visualização desse cenário despertou o interesse em elaborar a pesquisa, na tentativa de compreender e tornar mais clara a importância do empreendedorismo na formação dos alunos dos cursos superiores do campus. Nesse sentido, foi elaborada a seguinte questão, a ser respondida após a presente investigação: qual o entendimento dos docentes e discentes dos cursos superiores de tecnologia do IFSC, campus Florianópolis-Continente, sobre a contribuição do componente curricular de Empreendedorismo para a intenção em empreender?

Traçada a questão, objetivo geral da pesquisa, então, consistiu em investigar esse entendimento junto aos docentes e discentes dos cursos superiores de tecnologia do IFSC, campus Florianópolis-Continente.

Do objetivo geral, decorreram os objetivos específicos, quais sejam: 1) identificar como os alunos e professores do componente curricular de Empreendedorismo compreendem a formação empreendedora oferecida no IFSC; 2) conhecer quais atividades são propostas no IFSC e/ou que os alunos buscam para complementar sua formação empreendedora; 3) compreender as razões da existência ou inexistência de iniciativas empreendedoras por parte dos alunos do IFSC; e 4) propor um produto técnico que contribua para a formação empreendedora no IFSC.

\footnotetext{
${ }^{2}$ Art. 15. Componente curricular é a unidade que compõe a matriz curricular de um curso, podendo ser unidade curricular, estágio, trabalho de conclusão de curso, projeto integrador, prática clínica, ENADE, reconhecimento de saberes e atividades de extensão (RDP, 2014).
} 


\section{Procedimentos metodológicos}

A abordagem qualitativa adotada nesta investigação foi o estudo de caso (CRESWELL, 2010; MARCONI e LAKATOS, 2008). Para tanto, tomou-se como campo empírico o Instituto Federal de Santa Catarina, campus FlorianópolisContinente. Na visão de Alves-Mazzotti (2006, p. 650), o estudo de caso qualitativo "constitui uma investigação de uma unidade específica, situada em seu contexto, selecionada segundo critérios predeterminados e, utilizando múltiplas fontes de dados, que se propõe a oferecer uma visão holística do fenômeno estudado".

Os métodos de coleta de dados escolhidos envolveram a análise documental, a qual investigou os PPCs dos cursos e os planos de ensino utilizados com as duas turmas do componente curricular de empreendedorismo; e entrevistas com a docente e os discentes do componente curricular empreendedorismo.

A amostra foi definida como intencional (MARCONI e LAKATOS, 2008), pois se abarcou os alunos das duas turmas dos cursos Superiores de Tecnologia em Hotelaria e Gastronomia. Vale informar que esses cursos não possuem egressos, indicando que os alunos ainda possuem matrícula ativa na instituição.

Com relação ao corpo docente, participou da pesquisa somente uma professora, a que ministrou o componente curricular de Empreendedorismo para as turmas de Hotelaria e Gastronomia. Trata-se de uma docente com vínculo de professora substituta e que atuou nas duas turmas.

\section{Estrutura da dissertação}

Esta dissertação está, sequencialmente, organizada da seguinte maneira: introdução, cinco capítulos relacionados ao desenvolvimento da pesquisa, considerações finais do estudo e referencial bibliográfico consultado.

Inicialmente, apresentam-se os pressupostos metodológicos da pesquisa, os procedimentos na coleta de dados, o tipo de pesquisa realizada e a justificativa da opção por uma análise qualitativa. A introdução, engloba também a apresentação do 
tema e justificativa do estudo, a discussão da questão central da pesquisa, os objetivos da investigação e os procedimentos metodológicos utilizados.

O capítulo I apresenta um levantamento teórico da literatura sobre empreendedorismo, com ênfase na formação empreendedora; e a teoria das competências, com destaque para as competências empreendedoras.

O capítulo II apresenta o ensino de empreendedorismo no IFSC. Os tópicos discorrem sobre os documentos oficiais da instituição, incluindo o plano da atual gestão, além de apresentar uma abordagem sobre empreendedorismo e o ensino por competências.

O capítulo III traz a abordagem metodológica, apresentando a questãoproblema, os sujeitos da pesquisa, a amostra, o instrumento utilizado na coleta de dados, a coleta de dados em si, a análise dos dados e os aspectos éticos.

O capítulo IV apresenta os resultados da pesquisa, trazendo a caracterização dos sujeitos, o olhar dos discentes sobre as suas experiências com empreendedorismo, e a visão docente sobre as experiências oferecidas aos alunos no componente curricular de empreendedorismo.

O último capítulo é destinado à apresentação do produto técnico, elaborado a partir dos resultados obtidos na pesquisa. Por fim, são apresentadas as considerações finais, às quais se podem chegar com o estudo realizado. 


\section{CAPÍTULO 1 - O ENSINO DE EMPREENDEDORISMO E A EDUCAÇÃO POR COMPETÊNCIAS}

O conceito de empreendedorismo cada vez adquire mais força no Brasil. Inicialmente considerado como um fenômeno associado à criação de empresas, o empreendedorismo, mais recentemente, teve seu significado ampliado para manifestações humanas voltadas à realização de novos projetos organizacionais, independentes ou vinculados a uma organização já existente.

Atualmente, são difundidos estudos sobre o empreendedorismo, que tratam o fenômeno sob as mais variadas abordagens - indivíduos empreendedores, equipes empreendedoras, organizações empreendedoras e sociedades empreendedoras usando conceitos de disciplinas também diversas, tais como Economia, Psicologia, Sociologia, Administração e Engenharia (GIMENEZ, FERREIRA e RAMOS, 2008).

1.1 A origem e o significado dos termos empreendedorismo e empreendedor

O termo empreendedorismo deriva do termo francês entrepreneur (euse), traduzido para o inglês pelo termo intrepreneurship, que, por sua vez, deriva do termo latino imprehendere, ou prehendere, tendo seu correspondente "empreender" para a língua portuguesa (COAN, 2011).

O dicionário Petit Robert procura situar o verbete francês desde sua origem, por volta de 1430. Nessa época, o empreendedor era entendido como a pessoa que empreendia um negócio, como, por exemplo, a criação de determinada empresa, que traria grande crédito ao empreiteiro, à academia e à nação. Posteriormente, em 1614, o termo passou a designar a pessoa responsável pela execução de determinado trabalho - um especialista em matéria de construção, por contrato com uma empresa (COAN, 2011). Neste caso, fazia contrato de serviços de carpintaria, pintura, encanador, entre outros.

Com o tempo, o termo também passou a designar a pessoa que dirige uma empresa que coloca em movimento diversos insumos, tais como, recursos naturais, trabalho e capital, tendo em vista produzir ou fornecer bens e serviços. O 
"entrepreneur" pode ser um patrão, agricultor, artesão, comerciante ou um industrial (ROBERT, 1996).

Para Leite (2000), o termo entrepreneur pode ser traduzido na íntegra por empreendedor ou empresário; aquele que abre um negócio por conta própria e corre todo tipo de riscos. Essa compreensão, associada à ideia de negócios, contudo, apesar de bastante difundida, parece não ser a utilizada por parte considerável dos dicionários da língua portuguesa, mais conhecidos e anteriormente apresentados.

O verbete empreendedor, nos dicionários de língua portuguesa, tem definições relativamente diferentes do vocábulo francês. O mais comum é identificar o empreendedor como alguém ativo, arrojado, diligente, dinâmico, trabalhador, que se aventura em realizar tarefas difíceis, ou fora do comum. O verbete não está, necessariamente, relacionado à empresa ou a negócios, pois ser empreendedor pode significar: realizar, tentar, arriscar, resolver, experimentar, delinear, ensaiar, tentar colocar em prática algo laborioso, conforme Aurélio (2009), Fernandes (1999), Houaiss (2003), Michaelis (2011) Larousse (1999).

O termo também é utilizado para designar o criador de uma empresa, notadamente no campo econômico. Filion (1999) procura unir várias concepções em torno do que seja o empreendedor e o situa como um visionário, "uma pessoa que imagina, desenvolve e realiza visões" (p. 19).

\section{Quadro 1 - Conceitos empreendedorismo e empreendedor}

\begin{tabular}{|l|l|}
\hline Autor & Empreendedorismo e Empreendedor \\
\hline $\begin{array}{l}\text { MCCLELLAND, 1961, } \\
\text { citado por AVENI, } \\
\text { 2014, p. 27-28. }\end{array}$ & $\begin{array}{l}\text { O empreendedor se diferencia de outros agentes econômicos por sua } \\
\text { necessidade de realização. Os empreendedores buscam objetivos } \\
\text { desafiantes, têm preocupação com qualidade e gostam de resolver } \\
\text { problemas. }\end{array}$ \\
\hline $\begin{array}{l}\text { FILION, 1991 citado } \\
\text { por FILION, 2009, } \\
\text { p.19-21. }\end{array}$ & $\begin{array}{l}\text { O campo do empreendedorismo pode ser definido como aquele que estuda } \\
\text { os empreendedores. Enquanto o empreendedor é uma pessoa que imagina, } \\
\text { desenvolve e realiza visões. }\end{array}$ \\
\hline LEITE, 2002, p.1. & $\begin{array}{l}\text { Empreendedorismo é comportamento, segundo Drucker; é inovação, na } \\
\text { visão schumpteriana, e revela, sobretudo, um sujeito com uma forte } \\
\text { necessidade de realização, líder, dinâmico, flexível diante das mudanças, } \\
\text { dotado da capacidade de assumir riscos calculados, de excelente } \\
\text { percepção e com grande visão para o aproveitamento das oportunidades, } \\
\text { conforme McClelland. }\end{array}$ \\
& $\begin{array}{l}\text { Ser empreendedor significa ter capacidade de iniciativa, imaginação fértil } \\
\text { para conceber as ideias, flexibilidade para adaptá-las, criatividade para } \\
\text { transformá-las em uma oportunidade de negócio, motivação para pensar } \\
\text { conceitualmente, e a capacidade para ver, perceber a mudança como uma } \\
\text { oportunidade, levando a sério a gestão de seu negócio. }\end{array}$ \\
\hline
\end{tabular}




\begin{tabular}{|c|c|}
\hline $\begin{array}{l}\text { LIBERATO, 2007, p. } \\
1 .\end{array}$ & $\begin{array}{l}\text { Empreendedorismo [...] pressupõe, acima de tudo, a realização do indivíduo } \\
\text { por meio de atitudes de inquietação, ousadia e proatividade na sua relação } \\
\text { com o mundo. Define-se, também, como o tipo de comportamento que } \\
\text { favorece a interferência criativa e realizadora no meio, em busca de um } \\
\text { crescimento pessoal e coletivo, através do desenvolvimento da capacidade } \\
\text { intelectual para investigar e solucionar problemas, tomar decisões, ter } \\
\text { iniciativa e orientação inovadora, competências essas cada vez mais } \\
\text { exigidas na formação profissional e valorizadas no mundo do trabalho. }\end{array}$ \\
\hline $\begin{array}{l}\text { HISRICH et. al., } \\
\text { 2009, p.29-30. }\end{array}$ & $\begin{array}{l}\text { É um processo de criar algo novo, com valor, dedicando o tempo e o esforço } \\
\text { necessários, assumindo os riscos financeiros, psíquicos e sociais } \\
\text { correspondentes e recebendo as consequentes recompensas da satisfação } \\
\text { e da independência financeira e pessoal. }\end{array}$ \\
\hline AVENI, 2014, p. 42. & $\begin{array}{l}\text { O empreendedor, hoje em dia, é uma pessoa com alguma característica } \\
\text { pessoal de motivação, de conhecimentos e com experiências de trabalho } \\
\text { organizado ou experiências de tentativas de empreendimentos. Ele vive em } \\
\text { um ambiente empreendedor ou favorável ao empreendedorismo e percebe } \\
\text { oportunidades de mercado conseguindo se organizar para desenvolver } \\
\text { praticamente uma oferta para um novo mercado ou novos clientes. }\end{array}$ \\
\hline $\begin{array}{l}\text { GOMES et.al., 2014, } \\
\text { p. 157-158. }\end{array}$ & $\begin{array}{l}\text { Para o termo "empreendedorismo" os autores têm elaborado seus } \\
\text { conceitos, relacionando-os com o resultado da ação do empreendedor ou } \\
\text { como sendo um processo contínuo que tem como ator principal o próprio } \\
\text { empreendedor. Já para "empreendedor", os autores pesquisados } \\
\text { apresentam seus conceitos com características pessoais de um indivíduo. } \\
\text { Assim, o termo está geralmente associado ao comportamento desse } \\
\text { indivíduo. }\end{array}$ \\
\hline SOUZA, 2014, p. 13. & $\begin{array}{l}\text { Ser empreendedor é mais do que criar novos negócios, novos produtos, } \\
\text { novas oportunidades, é um estilo de vida, uma decisão de vida. Decisão de } \\
\text { agir, de buscar a felicidade, a sua realização pessoal, seus sonhos de tomar } \\
\text { em suas mãos as rédeas da sua vida e do seu destino e, ao tomar essa } \\
\text { atitude, tem como consequência o sucesso pessoal e profissional. }\end{array}$ \\
\hline
\end{tabular}

Fonte: (CONSONI, 2016, p. 71)

Os estudos realizados por Filion (1999), Leite (2002) e Hashimoto (2010) identificaram que os pioneiros no campo do empreendedorismo foram os economistas, com destaque para Cantillon (1755), Say $(1803,1815,1816,1839)$ e Schumpeter (1928).

De acordo com Filion (1999), Cantillon era considerado individualista, sem filiação a correntes de pensamento, mas preocupado com as questões econômicas e com a necessidade de racionalização como os europeus. Já Say, segundo Filion (1999) era economista, e foi reconhecido como o pai do empreendedorismo por dar os primeiros passos nesse campo de estudo. Para Say, empreendedores são pessoas que correm riscos, porque investem seu próprio dinheiro. Compram matéria-prima por certo preço, com o objetivo de processá-la e revendê-la por um preço ainda não definido (SAY apud FILION, 1999).

Na ótica de Cantillon (apud FILION, 1999), os empreendedores eram pessoas que aproveitavam as oportunidades com a perspectiva de obterem lucros, assumindo riscos intrínsecos. Say (apud FILION, 1999) fazia distinção entre empreendedores e 
capitalistas e entre os lucros de cada um. Nesta prática, associou os empreendedores à inovação e os considerava como os agentes da mudança. Say também já relacionava as qualidades e motivações do empreendedor. Para ele, o empreendedor "tem um conjunto de qualidades morais, capacidade de julgamento, continuidade e perseverança, conhecimento do mundo e dos negócios, coordenação e administração" (apud AVENI, 2014, p. 21).

Todavia, para Aveni (2014), foi no século XVIII que houve a necessidade de definir o agente econômico de maneira diferente, em virtude da forte mudança no paradigma econômico, decorrente da Revolução Industrial. Nesse momento, para ele, "o empreendedor, além das empresas comerciais, começa a vislumbrar oportunidades de negócio lucrativo também na produção industrial" (AVENI, 2014, p. 16).

Mais tarde, Schumpeter (1928), já no século XX, foi quem lançou os moldes do empreendedorismo tal como é mais conhecido atualmente, associando-o claramente à inovação e ao aproveitamento de oportunidades. Nesse contexto, Filion (1999), citando Schumpeter (1929), afirma que:

a essência do empreendedorismo está na percepção e no aproveitamento
das novas oportunidades no âmbito dos negócios [...] sempre tem a ver com
criar uma forma de uso dos recursos nacionais, em que eles sejam
deslocados de seu emprego tradicional e sujeitos a novas combinações. Esse
autor ainda comenta que depois de Schumpeter, outros estudiosos
continuaram trabalhando sobre empreendedorismo, porém, às vezes, nem
aparecem nos modelos clássicos de desenvolvimento econômico. E foi a
recusa dos economistas em aceitar modelos não quantificáveis que acabou
levando este universo do empreendedorismo a voltar-se para os
comportamentalistas ou behavioristas, em busca do conhecimento sobre
motivação e o comportamento do empreendedor (FILION, 1999, p. 7).

O primeiro comportamentalista a mostrar interesse pelos empreendedores foi Weber (1930), quando identificou o sistema de valores como um elemento fundamental para a explicação do comportamento empreendedor. Weber via os empreendedores como inovadores, pessoas independentes, cujo papel de liderança nos negócios inferia uma fonte de autoridade formal (AVENI, 2014).

Todavia, o autor que realmente deu início às contribuições das ciências do comportamento para o empreendedorismo foi David C. McClelland, na década de 1950, quando começou a estudar a história em busca de explicações para a ascensão e o declínio das civilizações. Sua principal contribuição teve origem ao despertar para a presença de heróis na literatura. Para ele, as gerações seguintes tomariam esses heróis como modelos e tenderiam a imitá-los em seu comportamento. Ou seja, ele 
observou que o povo, treinado sob tal influência, desenvolvia grande necessidade de realização, fazendo-o associar essa necessidade aos empreendedores (CONSONI, 2016, p. 67).

A necessidade de realização em si ou de motivação para a realização, poder e afiliação foram os objetos de estudos de McClelland, sendo, ao primeiro, dada maior ênfase. Apesar de mais tarde serem criticados por se limitarem a certos setores de atividade econômica e pela sua simplicidade, tais constatações deram origem aos estudos nessa área (FILION, 1999).

Foi, contudo, somente nos anos 1980 que o campo do empreendedorismo ganhou essa característica multidisciplinar tão importante, que cresceu e se espalhou por quase todas as ciências humanas e gerenciais, atraindo economistas, comportamentalistas, engenheiros, especialistas em finanças, especialistas em gerenciamento, especialistas na área de marketing, sujeitos interessados no estudo da criação de novos empreendimentos etc., cada um trazendo sua contribuição para esse campo de estudo (CONSONI, 2016).

Filion (1999), quase duas décadas depois, esclarecia que essa característica multidisciplinar explicava uma aparente confusão que se costuma fazer sobre o tema, pois refletia a lógica e as culturas divergentes dessas disciplinas.

Já Hisrich et.al. (2009, p. 30) afirmam que "cada definição é um pouco restritiva, uma vez que existem empreendedores em todas as áreas - educação, medicina, pesquisa, direito, arquitetura, engenharia, serviço social, distribuição e governo." Hashimoto (2010, p. 8), por sua vez, reforça as falas de Filion (1999) e Hisrich et al (2009), afirmando que "é mais fácil compreender o conceito de empreendedorismo do que encontrar uma forma de defini-lo em palavras".

Diante do exposto, dada sua amplitude, nesta pesquisa será utilizado, como referência, o conceito de empreendedorismo compilado por Consoni (apud SOUZA, 2012), que afirma:

ser empreendedor é mais do que criar novos negócios, novos produtos, novas oportunidades, é um estilo de vida, uma decisão de vida. Decisão de agir, de buscar a felicidade, a sua realização pessoal, seus sonhos de tomar em suas mãos as rédeas da sua vida e do seu destino e, ao tomar essa atitude, tem como consequência o sucesso pessoal e profissional (p. 13). 
Como mencionado, não se negam os outros conceitos, mas, para fins desta pesquisa, se acredita que este seja o ideal, uma vez que amplia o conceito para além do meio empresarial e comercial.

\subsubsection{Formação empreendedora}

A escola, e de forma complementar a empresa, apresentam um papel fundamental na formação do indivíduo, possuindo uma proposta tríplice para o estudo: o aluno desenvolve habilidades e adquire conhecimentos sobre temas específicos; desenvolve habilidades conceituais gerais e habilidades e atitudes pessoais que também podem ser facilmente utilizadas em tudo o que se faz (NASSIF et al., 2011).

Abreu e Masetto (1990), afirmam que os adultos aprendem muito mais com experiências da vida e com atividades centradas em problemas relevantes para suas vidas. Assim, para que a aprendizagem aconteça, é necessário que o seu objeto tenha significância ao aprendiz. Logo, como resultado do aprendizado haveria a mudança de comportamento, focada em objetivos reais, prescindindo de feedback e baseada no bom relacionamento interpessoal.

Oliveira Neto e Pinto (2010) contam que, de maneira geral, os meios de formação acadêmica e profissional na área técnica têm como metodologia didáticopedagógica posturas cujo enfoque prevê, para o aluno egresso de seus domínios, a obtenção de um emprego formal em empresas estatais ou privadas. Reforçam ainda que, até a década de 1980 eram estes os pensamentos que orientavam as questões da educação tanto no Brasil, quanto em outros países.

Pouca ou nenhuma ênfase, ou estímulo, foi destinado para orientar os estudantes a considerarem a opção de criar um negócio próprio. É natural que tenhamos um forte condicionamento do nosso meio cultural para considerar, em primeiro lugar, a 'caça ao emprego' sonhado (SANTOS, 1995).

Já na visão de Souza (2001), a formação do empreendedor passa pela aquisição de conhecimento e habilidades, experiências, capacidade criativa e inovadora. Essa autora refere-se ao desenvolvimento do perfil empreendedor como sendo a capacitação da pessoa para criar, conduzir e implementar o processo criativo, de elaborar novos planos de vida, de trabalho, de estudo, de negócio, sendo com isso 
responsável pelo seu próprio desenvolvimento, pelo de sua organização e da comunidade. Nessa perspectiva, surge a questão central de como realizar essa capacitação, ou seja, como desenvolver competências empreendedoras? Questão essa que desafia a universidade, o setor produtivo e o próprio Estado a estabelecerem novas formas de relações, e a desenvolverem, novas Metodologias de ensino.

\subsubsection{Histórico da formação empreendedora}

O início do ensino de empreendedorismo teve origem nos Estados Unidos com Myles Mace lecionando o primeiro curso de empreendedorismo em fevereiro de 1947, na Escola de Administração de Harvard (KATZ, 2003). Importante destacar a intencionalidade da criação desse curso, completamente diferente dos objetivos atuais: qualificar ex-combatentes da Segunda Guerra Mundial para o mercado de trabalho, principalmente no que diz respeito a geração do auto emprego, visto que sua economia estava em transição devido ao colapso da indústria de armas (VESPER e GARTNER, 1997).

No entanto, a disseminação dos cursos de empreendedorismo ou oferta de disciplinas nesse campo por parte dos programas de graduação e pós-graduação nos Estados Unidos ocorreu vagarosamente. Nas décadas que se seguiram, o tema empreendedorismo não entrou em moda, reflexo da baixa extensão das atividades empreendedoras do período. Durante as décadas de 1950 e 1960, o número de corporações per capita mostrou um constante declínio, com um aumento apenas de grandes corporações, seguido pelo decréscimo de faculdades e universidades que incluíam o empreendedorismo em seus currículos (VESPER e GARTNER, 1997; SEXTON e BOWMAN, 1984).

Wyckham (1989 apud GUIMARAES, 2002) menciona os seguintes problemas: na época havia uma grande dependência financeira das universidades em relação às grandes empresas, que financiavam pesquisas, doavam equipamentos e bolsas de estudo etc.; e, por fim, afirma que o sistema de promoção de docentes nas universidades restringia a geração de disciplinas voltadas para criação de empresas.

Apenas em 1970, as universidades e escolas de negócios começaram a aumentar seus cursos voltados para o ensino de empreendedorismo, totalizando 16 
universidades apresentando estes cursos em suas grades curriculares. Vesper e Gartner (1997) enfatizam que é difícil pontuar exatamente as razões desse crescimento, mas que a razão mais provável estava relacionada a freada na queda do número de corporações per capita, voltando a crescer a abertura de novos negócios.

A expansão definitiva do ensino de empreendedorismo foi na década de 1980 em virtude de críticas que começaram a proliferar envolvendo lacunas na formação em gestão, assim como a expansão de periódicos especializados sobre o tema. Guimarães (2002, p. 7) destaca, ainda, como um dos fatores preponderantes a expansão do ensino de empreendedorismo nas disciplinas dos cursos de graduação e pós-graduação norte-americana o Small Business Administration - SBA ${ }^{3}$.

Em 1994, cerca de 120 mil estudantes americanos estavam realizando cursos de empreendedorismo ou gestão de pequenos negócios, em uma infraestrutura que saltou para a casa de 2.200 cursos, oferecidos em pelo menos 1.600 faculdades, 100 centros especializados, além da criação de 44 jornais acadêmicos em língua inglesa sobre o tema (KATZ, 2003).

O ensino de administração e o de empreendedorismo no Brasil data de período bem mais recente se comparado aos norte-americanos e europeus, devido a sua tardia industrialização que somente a partir de 1950 apresentou um crescimento mais exponencial.

Nesse contexto, vem a ser importante destacar que 0 ensino de empreendedorismo estava inserido no campo da administração como uma subárea e, recentemente, está sendo estudado como campo específico de conhecimento, porém com seus conceitos e metodologias ainda em fase de consolidação e formação, sem haver um consenso dentre os autores (HENRY, HILL e LEITH, 2005).

Isso ocorre, principalmente, pelos diferentes significados de empreendedorismo empregados, por uma variedade de diferentes cursos de empreendedorismo e por diferentes formas com que o rótulo empreendedorismo é usado pelas universidades na promoção de diferentes agendas. Desse modo,

\footnotetext{
${ }^{3}$ [...] instituição cuja missão e apoiar e estimular o desenvolvimento das pequenas empresas, por meio do programa Small Business Institute Program - SBI. Iniciado em 1972, no Texas Tech University, o programa oferecia suporte financeiro as universidades interessadas em organizar cursos nos quais, em uma das atividades obrigatórias, os alunos atuariam, sob a supervisão de professores, como consultores de pequenas empresas.
} 
encontrar um razoável caminho para padronizar programas e cursos de empreendedorismo é um verdadeiro desafio (VESPER e GARTNER, 1997).

A introdução de cursos voltados para o empreendedorismo justificou-se pela crescente conscientização e tomada de posição por parte das universidades, no sentido de proporcionar aos seus discentes competências que Ihes deem condições de conseguir um emprego, assim como de sobreviver nesta sociedade altamente competitiva.

Dessa forma, na década de 1980, com a crise dos empregos e a busca das corporações por empregados que detivessem o perfil empreendedor, houve o início da inserção dos cursos de empreendedorismo, ao passo que os pesquisadores percebiam que era necessário formar um profissional capaz de atuar na sua área, mas que ao mesmo tempo tivesse conhecimentos para criar seu próprio negócio. Era preciso transformar o conhecimento que está na universidade em produto ou serviço. Mas para isso e preciso desenvolver nos alunos suas capacidades empreendedoras para que possam vir a desenvolver as boas ideias (SOUZA et al., 2005).

Segundo Souza et al. (2005), a criação de uma metodologia para o desenvolvimento dessa competência envolve bem mais que a aquisição de conhecimentos, mas o aprender a aprender, a ser, a fazer e, principalmente, a conviver.

Fazem parte ainda dos princípios da formação empreendedora: aprender a compreender o mundo, analisando e definindo as diferentes facetas do seu contexto individual e institucional; comunicação e colaboração em contexto competitivo; raciocínio criativo e resolução de problemas encarando a vida em uma perspectiva criativa; domínio pessoal, processo no qual é desenvolvido o autoconhecimento e o auto desenvolvimento; pensamento sistêmico, possibilitando clareza na percepção do todo e das relações entre as partes; liderança, tratada muito mais como uma característica adquirida, envolvendo duas direções, à vontade e a determinação e o conhecimento acumulado em um dado setor, incluindo a aquisição de uma série de competências distintas (SOUZA, 2001). 


\subsection{Competência empreendedora e a educação}

Segundo Mamede e Moreira (2005, p. 4), "a competência empreendedora pode ser tratada tanto como competência do indivíduo, quanto relacionada à prática administrativa, devido às diferentes tarefas que desempenham". Para eles, as ações empreendedoras estão associadas às competências por representarem o senso de identificação de oportunidades, a capacidade de relacionamento em rede, as habilidades conceituais, a capacidade de gestão, a facilidade de leitura, o posicionamento em cenários conjunturais e o comprometimento com interesses individuais e da organização.

Essa junção de competências com ações empreendedoras levou à criação do conceito de competência empreendedora definido por Snell e Lau (1994), o qual consiste em corpo de conhecimento, área ou habilidade, qualidades pessoais ou características, atitudes ou visões, motivações ou direcionamentos que, de diferentes formas, podem contribuir para o pensamento ou ação efetiva do negócio. Para esses autores, a arte de criar e gerenciar um pequeno negócio é relacionada ao plano de vida do empreendedor, aos valores e à sua característica pessoal e isso é refletido na amplitude desta definição.

Antonello (2005) definiu competência empreendedora como um conjunto de conhecimentos, habilidades e atitudes que viabilizam a um indivíduo imprimir sua visão, estratégias e ações na criação de valor (tangíveis ou intangíveis) para a sociedade. Assim, o conceito de competência empreendedora está mais próximo dos conceitos de competências individuais, muito embora a primeira já tenha, na literatura, um corpo teórico próprio.

Optou-se por considerar, neste estudo, competência empreendedora como um corpo de conhecimento, área ou habilidade, qualidades pessoais ou características, atitudes ou visões, motivações ou direcionamentos que, de diferentes formas, podem contribuir para o pensamento ou ação efetiva do negócio (SNELL e LAU, 1994) e que permite a um indivíduo imprimir ações, estratégias e sua visão na criação de valor tangível e intangível para a sociedade (ANTONELLO, 2005).

Dentro do tema de competência empreendedora, alguns autores têm se preocupado em criar tipologias ou modelos que possibilitem a identificação, por parte dos pesquisadores, de conhecimentos, habilidades, atitudes, enfim, de competências 
necessárias ao desenvolvimento de suas atividades. Entre eles, dois trabalhos foram identificados na literatura: o de Cooley (1990) e o de Man e Lau (2000).

A classificação de Cooley (1990), voltada para os empreendedores, foi revista e adaptada do modelo de competências de McClelland e contém uma lista com 10 competências empreendedoras, a saber: busca de oportunidade e iniciativa; persistência; comprometimento; exigência de qualidade e eficiência; assunção de riscos calculados; estabelecimento de metas; busca de informações; planejamento e monitoramento sistemáticos; persuasão e rede de contatos; independência e autoconfiança.

Morales (2004) utilizou essa tipologia para fazer um estudo sobre competências, buscando medir o grau de relação entre as competências empreendedoras e os tipos psicológicos junguianos. A pesquisa foi feita no estado de Santa Catarina com 82 empreendedores. As características comportamentais empreendedoras predominantes foram: a) busca de informações; b) persuasão e redes de contato; e c) persistência. Por fim, observou-se baixa correlação entre as características empreendedoras e os traços psicológicos.

Para Man e Lau (2000), a competitividade na micro e pequena empresa (MPE) é fortemente influenciada pelas competências do empreendedor. Partindo deste pressuposto, esses autores realizaram diversos estudos empíricos entre 1993 e 1999 que resultaram em uma categorização de competências em seis áreas distintas descritas a seguir.

Competências de oportunidade: estão relacionadas à identificação, avaliação e busca de oportunidades de negócios. De acordo com Paiva Jr., Leão e Mello (2003, p. 2), "um empreendedor deve estar apto a identificar os cenários favoráveis aos objetivos organizacionais e atuar sobre as potenciais chances de negócios por meio da sua avaliação de modo a transformá-las em situações positivas”. Essa capacidade de visualizar o ambiente que antecede e ampara o processo de decisão é fundamental para os empreendedores, que, segundo Filion (1999), têm visões cuja elaboração demanda tempo, comprometimento e imaginação sobre o objetivo a ser perseguido e os caminhos necessários para realizá-lo.

Competências de relacionamento: referem-se aos relacionamentos pessoais do empreendedor (GRANOVETTER, 1985) que podem influenciar na definição do caminho a ser seguido em um determinado negócio, os quais estão classificados em três níveis por Filion (1991): primários (abrangem os contatos familiares e as pessoas 
mais próximas); secundários (amizades e grupos sociais: clubes, religião, política, trabalho) e terciários (contatos com um campo de interesse; ocorrem através de viagens, cursos, exposições, feiras e congressos).

Competências conceituais: dizem respeito às capacidades de avaliar situações de risco que surgem em decorrência de suas ações em qualquer ambiente, ou seja, o empreendedor tende a correr riscos calculados (DORNELAS, 2007) e também à capacidade de perceber situações por ângulos diferentes e de forma positiva. Assim, a inovação permite a diferenciação e integra a dimensão conceitual da competência empreendedora.

Competências administrativas: envolvem a eficiente alocação de talentos humanos, recursos físicos, financeiros e tecnológicos. Para tanto é preciso que o empreendedor tenha a capacidade de planejar, organizar, comandar, motivar, delegar e controlar, enfim, de administrar o empreendimento e seus funcionários (MAN e LAU, 2000).

Competências estratégicas: vinculam-se à escolha e implementação das estratégias do empreendimento, nas quais os empreendedores visualizam panoramas de longo prazo e objetivos de médio e curto prazos alcançáveis e realistas, além de elaborar estimativas de viabilidade financeira e de mecanismos de controle dos seus resultados (MAN e LAU, 2000).

Competências de comprometimento: demandam a habilidade de manter a dedicação do dirigente ao negócio, principalmente em situações adversas, além de demonstrar a dedicação do empreendedor e do seu trabalho árduo, participando de tudo o que acontece na organização, mesmo que em detrimento de sua vida pessoal.

Esta competência está relacionada com a capacidade que o empreendedor tem de recomeçar a atividade empresarial, mesmo após situações de insucesso, ou, então, com a disposição de não abandonar o negócio, mesmo quando ocorrem crises setoriais ou na economia (MAN e LAU, 2000).

Várias pesquisas foram realizadas utilizando especificamente a tipologia de competências empreendedoras de Man e Lau (2000), como por exemplo: 


\section{Quadro 2 - Pesquisas realizadas utilizando a tipologia de competências}

\section{empreendedoras}

\begin{tabular}{|l|l|}
\hline Paiva Jr., Leão e Mello (2003) & $\begin{array}{l}\text { Pesquisaram dirigentes de empresas brasileiras } \\
\text { de médio e grande porte que atuam em serviços } \\
\text { da nova economia, sediadas no eixo Rio-São } \\
\text { Paulo }\end{array}$ \\
\hline Mamede e Moreira (2005) & $\begin{array}{l}\text { Entrevistaram dois empreendedores do ramo } \\
\text { hoteleiro de Fortaleza, sendo um cearense e } \\
\text { outro português }\end{array}$ \\
\hline Fonseca, Mello, Paiva Jr. et al. (2006) & $\begin{array}{l}\text { Pesquisaram o empreendedor Miguel Abuhab, } \\
\text { fundador de uma das maiores empresas de } \\
\text { Tecnologia da Informação do Brasil, DATASUL, } \\
\text { considerado duas vezes o melhor empreendedor } \\
\text { do ano amplamente reconhecido como um } \\
\text { empreendedor de sucesso }\end{array}$ \\
\hline Paiva Jr., Guerra, Oliveira, et al. (2006) & $\begin{array}{l}\text { Entrevistaram dirigentes de duas empresas } \\
\text { graduadas pelo sistema de incubação que atuam } \\
\text { na Região Metropolitana do Recife }\end{array}$ \\
\hline Honma (2007) & $\begin{array}{l}\text { Analisou as competências empreendedoras dos } \\
\text { proprietários de seis hotéis de pequeno e médio } \\
\text { porte em Curitiba/PR }\end{array}$ \\
\hline Dias, Nardelli e Vilas Boas (2008) & $\begin{array}{l}\text { Identificaram as competências empreendedoras } \\
\text { relacionadas aos cinco dirigentes } \\
\text { empreendedores ganhadores do prêmio TOP } \\
\text { Empresarial 2006, promovido pelo SEBRAE/RJ }\end{array}$ \\
\hline
\end{tabular}

Fonte: autora, a partir de Man e Lau (2000).

Estes estudos parecem evidenciar que as competências empreendedoras abrangem predominantemente os fatores oportunidade e gestão. Tal ênfase parece convergir para os principais temas de pesquisa em empreendedorismo, que têm atraído a atenção dos pesquisadores nas últimas décadas em face das características particulares dos empreendedores e das suas dificuldades na criação e desenvolvimento de novas empresas. Assim, constatou-se que o desenvolvimento das competências, embora diferenciadas nos diversos setores, está associado a um processo de aprendizagem (BITENCOURT, 2005; FEUERSCHÜTTE e GODOI, 2007; BARINI FILHO, 2008).

Competências e aprendizagem são, portanto, abordagens complementares, pois, para que haja desenvolvimento da aprendizagem, é preciso repensar as competências das pessoas, ao mesmo tempo em que o desenvolvimento das competências é baseado num processo contínuo de aprendizagem, criando um círculo vicioso (BITENCOURT, 2005). Afinal, não há desenvolvimento sem aprendizagem, constituindo-se esta um processo necessário para a aquisição de competências. Portanto, a mesma ênfase encontrada no potencial explicativo dos 
estudos que conectam as categorias de aprendizagem e competências na literatura de nível individual e organizacional tem sido dada na literatura de empreendedorismo, ainda que de forma incipiente.

\subsection{A competência no contexto educacional}

Para Perrenoud (1999), múltiplos são os significados da palavra competência. Dentre eles, o autor destaca a capacidade de agir eficazmente em um determinado tipo de situação, apoiando-se em conhecimentos, mas sem limitar-se a eles. $O$ autor afirma que a construção de competências é inseparável da formação de esquemas de mobilização dos conhecimentos com discernimento, em tempo real, ao serviço de uma ação eficaz.

De acordo com Assmann e Sung (2000), os termos competência e habilidade, que passaram a fazer parte de uma nova linguagem pedagógica adotada pelo MEC, estão em consonância com as reformas educacionais mundo afora. Segundo os autores, essas reformas consideram o desenvolvimento de competências básicas para o aprendiz, cujo patamar mínimo seria aprender a aprender e aprender para toda vida, ou seja, continuar criativo e "aprendente".

Os autores apontam que essa perspectiva se opõe ao sentido de educação como transmissão de conhecimentos e que os documentos da UNESCO, que versam sobre a educação para o século 21 e instauram essa nova linguagem (competências e habilidades), são acusados de representar o pensamento neoliberal.

$\mathrm{Na}$ visão de Assmann e Sung (2000), tais documentos não são fechados ideologicamente. Ao contrário, abrem horizontes para o papel da educação na luta contra a exclusão e para a participação democrática. Na visão dos autores, o desenvolvimento econômico perde sentido sem o desenvolvimento social. Por essa razão, esses documentos prometem uma visão de mundo democrático e não neoliberal, como defende a maioria dos críticos do ensino por competências.

Assim, para esses autores, o termo competência passou a ocupar um lugar importante no cenário educacional. Eles citam Demo (1997) ao dizer que, talvez o resultado mais consistente das teorias de aprendizagem seja a descoberta de que aprender é uma das marcas da competência humana. Termo utilizado por Assmann 
e Sung (2000) para se referir à condição ou competência de continuar aprendendo no que se refere aos relacionamentos interpessoais e à convivência humana.

Na perspectiva da educação profissional, Ramos (2006) abordou o conceito de competência, relacionando-o a outro que considera mais abrangente: o de qualificação profissional. Citando Schwartz (1995), a autora define qualificação profissional como uma relação social cujo conteúdo sócio histórico se expressa nas dimensões conceitual, social e experimental. De acordo com ela, a primeira dimensão define a qualificação como o registro de conceitos teóricos formalizados. A segunda coloca a qualificação no âmbito das relações sociais que se estabelecem entre os conteúdos das atividades e o reconhecimento social. A terceira dimensão, a experimental, está relacionada ao conteúdo real do trabalho, ao conjunto dos saberes que são postos em ação na realização do trabalho. Estaria, portanto, relacionada às habilidades, "que têm natureza mais instrumental e correspondem ao "saber fazer".

A noção de competência apresentada nas diretrizes da educação profissional, na opinião de Ramos (2006), provoca um movimento simultâneo de reafirmação e negação do conceito de qualificação. Para ela, a noção de competência faz com que a dimensão experimental da qualificação se sobressaia em relação às outras dimensões.

Em suas palavras,

[...] desenvolver as competências dos trabalhadores sob essa ótica exige pelo menos: a) compreender as experiências de vida, sabendo que, na sociedade capitalista, o trabalho toma a forma de mercadoria ao mesmo tempo que produz riqueza; b) integrar a experiência de vida com a experiência escolar; c) promover a observação do real; d) partir do senso comum dos trabalhadores e de suas experiências mais imediatas para a superação do senso comum pela concepção de mundo unitária e a compreensão de que as experiências são historicamente determinadas pela condição de classe. As competências que se desenvolvem na escola unitária, síntese de uma escola ativa e criadora, não são mecanismos de adaptação à realidade dada, mas são construções intelectuais elevadas que possibilitam à classe trabalhadora ser classe dirigente (p. 298).

Pode-se, assim, compreender que, para a autora, o conceito de competência pode levar ao entendimento da qualificação profissional como uma ação que privilegie apenas o "saber fazer", minimizando a importância do desenvolvimento profissional mais amplo que dê conta das três dimensões apontadas. Ramos (2006) afirmou que 
a educação deve possibilitar a compreensão da realidade com o fim de dominá-la e transformá-la, ao invés de ser pacificada por ela.

1.3.1 Conceito de Competências na visão de outros países e do Brasil

Estudos têm sido realizados em diversos países, destacando-se a conceituação do tema pelas escolas americanas, francesas, assim como uma visão brasileira de sua aplicação na realidade de nossas organizações. Autores americanos abordam o conceito de competências desde 1973, já considerando a sua contribuição efetivamente prática na obtenção de resultados, conforme apresentado nos quadros 1,2 e 3.

\section{Quadro 3 - Conceitos de competências na visão americana}

\begin{tabular}{|l|l|l|}
\hline Autor & Ano & Conceito de Competências \\
\hline Boyatzis & 1982 & $\begin{array}{l}\text { "É um conjunto de características pessoais que definem uma performance } \\
\text { superior" }\end{array}$ \\
\hline McClelland & 1987 & $\begin{array}{l}\text { "são habilidades medidas que são traduzidas em um resultado social } \\
\text { prático" }\end{array}$ \\
\hline $\begin{array}{l}\text { Spencer and } \\
\text { Spencer }\end{array}$ & 1993 & $\begin{array}{l}\text { "É uma característica profunda de um indivíduo, que prediz quem fez algo } \\
\text { bem ou mal, quando medida em um critério específico ou padrão" }\end{array}$ \\
\hline Mirabile & 1997 & $\begin{array}{l}\text { "É um conjunto de conhecimentos, habilidades, aptidão ou característica } \\
\text { associada com alta performance no trabalho" }\end{array}$ \\
\hline Mclagan & 1997 & $\begin{array}{l}\text { "características e atributos das pessoas que executam tarefas e outros } \\
\text { ligados à tarefa em si que são observados mediante comportamentos } \\
\text { refletidos em ações" }\end{array}$ \\
\hline Green & 1999 & $\begin{array}{l}\text { "competência é uma descrição escrita de hábitos de trabalhos mensuráveis } \\
\text { e habilidades pessoais utilizadas para alcançar um objetivo de trabalho" }\end{array}$ \\
\hline
\end{tabular}

Fonte: (NASSIF et. al, 2011)

Na visão francesa, o conceito de competências vem evoluindo considerando principalmente a aplicabilidade prática do conceito, assim como a influência da socialização no seu desenvolvimento.

\section{Quadro 4 - Conceito de Competências na Visão Francesa}

\begin{tabular}{|l|l|l|}
\hline Autor & Ano & Conceito de Competências \\
\hline Le boterf & 1994 & $\begin{array}{l}\text { "Três eixos: pessoa (biografia e socialização), formação educacional e } \\
\text { experiência profissional" }\end{array}$ \\
\hline
\end{tabular}




\begin{tabular}{|l|c|l|}
\hline Durand & 1998 & $\begin{array}{l}\text { "São os conhecimentos, habilidades e atitudes representam recursos ou } \\
\text { dimensões interdependentes da competência" }\end{array}$ \\
\hline Zarifian & 2001 & $\begin{array}{l}\text { "Traz para a definição de competência um contexto prático. ... não são } \\
\text { apenas os recursos inatos ou adquiridos, mas aqueles que sabemos como } \\
\text { colocar em ação" }\end{array}$ \\
\hline & 2003 & $\begin{array}{l}\text { "É tomar iniciativa e assumir responsabilidades frente a situações } \\
\text { profissionais complexas (aliado), utilizando-se de inteligência prática" }\end{array}$ \\
\hline $\begin{array}{l}\text { "O que se sobressai dos recursos adquiridos por um indivíduo. E } \\
\text { competência é a utilização desses recursos na prática" }\end{array}$ \\
\hline Kets De Vries & 1995 & $\begin{array}{l}\text { "Concebida como característica que engloba diferentes traços de } \\
\text { personalidade, habilidades e conhecimento, influenciados pela experiência, } \\
\text { "capacitação, educação, história familiar e aspectos demográficos } \\
\text { peculiares à pessoa" }\end{array}$ \\
\hline Man and Lau & 2000 \\
\hline
\end{tabular}

Fonte: (NASSIF et. al, 2011)

Para os autores brasileiros, o conceito de competências se complementa com as demais visões, à medida que consideram os inputs, isto é, representam as características que um indivíduo possui, considerando os seus conhecimentos, habilidades e atitudes que proporcionam um melhor resultado, os outputs, que é a capacidade de aplicar e mobilizar seus conhecimentos em um determinado contexto, possibilitando melhor desempenho, visão de longo prazo e uma atuação integradora e arrojada para superar os inúmeros desafios, como se pode observar na síntese apresentada no quadro a seguir:

\section{Quadro 5 - Conceito de competências}

\begin{tabular}{|c|c|c|}
\hline Autor & Ano & Conceito de Competências \\
\hline Ruas & 2001 & $\begin{array}{l}\text { "A questão das competências se coloca em um espaço de interação entre } \\
\text { pessoas; e a demanda da organização em seus processos de trabalho e } \\
\text { mercado" }\end{array}$ \\
\hline Resende & 2000 & $\begin{array}{l}\text { "É a transformação de conhecimentos, aptidões, habilidades, interesses em } \\
\text { resultados práticos" }\end{array}$ \\
\hline $\begin{array}{l}\text { Fleury } \\
\text { Fleury }\end{array}$ & 2001 & $\begin{array}{l}\text { "é um saber agir responsável e reconhecido que agreguem valor econômico } \\
\text { à organização e valor social ao indivíduo" }\end{array}$ \\
\hline Rabaglio & 2004 & $\begin{array}{l}\text { "Conhecimentos, habilidades, atitudes e comportamentos que permitem ao } \\
\text { indivíduo desempenhar com eficácia tarefas, em qualquer situação" }\end{array}$ \\
\hline Dutra & 2004 & $\begin{array}{l}\text { "Características do indivíduo, com o conceito de entrega (agregação de } \\
\text { valor)" }\end{array}$ \\
\hline
\end{tabular}

Fonte: (NASSIF et. al, 2011)

Após a análise das abordagens acima mencionadas, Bittencourt (2002) destaca que o conceito relaciona seis aspectos: 
Quadro 6 - Conceito de competências, a partir de Bittencourt (2002)

\begin{tabular}{|l|l|}
\hline Formação & $\begin{array}{l}\text { Desenvolvimento de conceitos, habilidades e } \\
\text { atitudes }\end{array}$ \\
\hline Ação & $\begin{array}{l}\text { Práticas de trabalho, capacidade de mobilizar } \\
\text { recursos, fato esse que a difere do conceito de } \\
\text { potencial }\end{array}$ \\
\hline Resultados & $\begin{array}{l}\text { O objetivo do desenvolvimento da competência } \\
\text { está relacionado à busca de melhores } \\
\text { desempenhos }\end{array}$ \\
\hline Perspectiva Dinâmica & $\begin{array}{l}\text { A definição de competências deve ser } \\
\text { constantemente questionada }\end{array}$ \\
\hline Autodesenvolvimento & $\begin{array}{l}\text { A responsabilidade maior desse processo deve } \\
\text { ser atribuída ao próprio indivíduo }\end{array}$ \\
\hline Interação & $\begin{array}{l}\text { O desenvolvimento de competência ocorre a } \\
\text { partir do relacionamento com outras pessoas. }\end{array}$ \\
\hline
\end{tabular}

Fonte: autora (2016).

$\mathrm{Na}$ visão dos autores americanos pesquisados, conforme exposto no quadro três, as competências são inputs das pessoas, isto é, representam as características que um indivíduo possui, considerando os seus conhecimentos, habilidades e atitudes que proporcionam um melhor resultado. Já para os autores franceses, as competências podem ser consideradas outputs de um indivíduo, em aplicar e mobilizar seus conhecimentos em um determinado contexto.

Já os pesquisadores brasileiros, conforme apresentado no quadro cinco, consideram a integração desses dois conceitos. Para eles, as competências são conhecimentos, habilidades e atitudes que agregam valor econômico para a organização e valor social ao indivíduo. Portanto, elas emanam em um espaço de interação entre as pessoas e seus saberes e capacidades e demandas das organizações no campo dos processos de trabalho essenciais e relacionais (NASSIF et. al. 2011, p. 4).

Quanto aos tipos de competências, Ruas (2001) afirma que as competências estão relacionadas a duas dimensões estratégicas: uma dimensão individual e uma dimensão corporativa.

No âmbito individual, as competências para Zarifian (2001), Parry (1996) e Ruas (2001), extrapolam o conceito de qualificação, pois se refere à capacidade da pessoa de assumir iniciativas, ir além das atividades prescritas, ser capaz de compreender e dominar novas situações de trabalho, ser responsável e ser reconhecida por isso, não limitando-se apenas às tarefas ou ao conhecimento do mesmo. 
Desta, destacam-se as competências gerenciais, que, de acordo com Tushman and Nadler (1997), correspondem às habilidades para resolução de problemas, identificação de oportunidades e ameaças, capacidade para lidar com a incerteza e implementação conjunta de decisões.

No âmbito corporativo, as competências fazem parte da personalidade de cada organização, que as diferenciam das demais e geram vantagem competitiva (DRUCKER, 1999).

Segundo Ruas (2001), as competências organizacionais são coletivas, que aparecem sob a forma de processos de produção e/ou atendimento, nos quais estão incorporados conhecimentos tácitos e explícitos, sistemas e procedimentos de trabalho, entre outros elementos menos visíveis como princípios, valores e culturas dominantes na organização.

Zarifian (2001) sugere que o modelo de competência envolve três dimensões centrais, frente ao novo paradigma das organizações contemporâneas: competências participativas: relacionadas à capacidade dos empregados entenderem uma organização como um todo e de saber como ela funciona; competências transversais: relacionadas ao entendimento do processo integral da produção ou do serviço, incluindo também a cooperação em equipes e em redes de diferentes setores; e competências sociais: relacionadas a integrar os aspectos de autonomia, responsabilidade e comunicação social, necessárias para o futuro. Esse autor propõe como definição que competência é a habilidade em mobilizar as capacidades não apenas para a execução de uma atividade, mas também da abrangência da visão e da interação dos mais diversos aspectos envolvidos no negócio. Para o autor essas competências serão reveladas na capacidade de tomada de decisão.

Além da tipologia das competências baseadas no âmbito individual e organizacional, Resende (2000) destaca outros tipos a partir do segmento de atuação, quais sejam: as técnicas, intelectuais, cognitivas, relacionais, sociais e políticas, didático-pedagógica, metodológica, liderança e organizacionais. Frente à relevância do entendimento e efetiva contribuição das competências empreendedoras para o desenvolvimento dos negócios, os estudos e pesquisas desse tema têm sido crescentes nesta década.

Considerando a diversidade de conceitos existentes sobre competências, para fins desse estudo, será utilizado o seguinte conceito "as competências são conhecimentos, habilidades e atitudes que agregam valor econômico para a 
organização e valor social ao indivíduo. Portanto, elas emanam em um espaço de interação entre as pessoas e seus saberes e capacidades e demandas das organizações no campo dos processos de trabalho essenciais e relacionais" (NASSIF et. al. 2011, p. 4). 


\section{CAPÍTULO 2 - O ENSINO DE EMPREENDEDORISMO NO IFSC E O CURRÍCULO POR COMPETÊNCIAS}

O MEC instituiu por intermédio do CNE, as Diretrizes Curriculares Nacionais Gerais para a organização e o funcionamento dos cursos superiores de tecnologia. Com efeito norteador este documento menciona em seu art. 1ํ "A educação profissional de nível tecnológico, integrada às diferentes formas de educação, ao trabalho, à ciência e à tecnologia, objetiva garantir aos cidadãos o direito à aquisição de competências profissionais que os tornem aptos para a inserção em setores profissionais nos quais haja utilização de tecnologias".

A palavra "competências" está bastante presente neste documento, ao passo que a palavra empreendedorismo aparece, por ordem de importância, no topo do documento. Para efeitos de entendimento e compilação, serão relacionadas as respectivas ocorrências, a seguir:

Art. $2^{\circ}$ Os cursos de educação profissional de nível tecnológico serão designados como cursos superiores de tecnologia e deverão:

I - incentivar o desenvolvimento da capacidade empreendedora ${ }^{4}$ e da compreensão do processo tecnológico, em suas causas e efeitos;

III - desenvolver competências profissionais tecnológicas, gerais e específicas, para a gestão de processos e a produção de bens e serviços;

$\S 1^{\circ}$ O histórico escolar que acompanha o diploma de graduação deverá incluir as competências profissionais definidas no perfil profissional de conclusão do respectivo curso.

$\S$ 2ㅇ O histórico escolar que acompanha o Certificado de Qualificação Profissional de Nível Tecnológico deverá incluir as competências profissionais definidas no perfil de conclusão do respectivo módulo.

Art. 6ㅇ A organização curricular dos cursos superiores de tecnologia deverá contemplar 0 desenvolvimento de competências profissionais e será formulada em consonância com o perfil profissional de conclusão do curso, o qual define a identidade do mesmo e caracteriza o compromisso ético da instituição com os seus alunos e a sociedade.

$\S 11^{\circ} \mathrm{A}$ organização curricular compreenderá as competências profissionais tecnológicas, gerais e específicas, incluindo os fundamentos científicos e humanísticos necessários ao desempenho profissional do graduado em tecnologia.

$\S 2^{\circ}$ Quando o perfil profissional de conclusão e a organização curricular incluírem competências profissionais de distintas áreas, o curso deverá ser classificado na área profissional predominante.

Art. 8o Os planos ou projetos pedagógicos dos cursos superiores de tecnologia a serem submetidos à devida aprovação dos órgãos competentes, nos termos da legislação em vigor, devem conter, pelo menos, os seguintes itens: (...)IV - organização curricular estruturada para o desenvolvimento das competências profissionais, com a indicação da carga horária adotada e dos

\footnotetext{
${ }^{4}$ Grifo da autora.
} 
planos de realização do estágio profissional supervisionado e de trabalho de conclusão de curso, se requeridos; VI - critérios de aproveitamento e procedimentos de avaliação de competências profissionais anteriormente desenvolvidas;

Art. 9o É facultado ao aluno o aproveitamento de competências profissionais anteriormente desenvolvidas, para fins de prosseguimento de estudos em cursos superiores de tecnologia.

$\S 1^{\circ}$ As competências profissionais adquiridas em cursos regulares serão reconhecidas mediante análise detalhada dos programas desenvolvidos, à luz do perfil profissional de conclusão do curso. $\S 2^{\circ}$ As competências profissionais adquiridas no trabalho serão reconhecidas através da avaliação individual do aluno.

Embora não apresente clara e referenciada em seus regulamentos, o IFSC explicita no teor dos documentos, a adoção das competências na concepção do currículo.

\subsection{Competências no âmbito do IFSC}

O termo competência passou a fazer parte das discussões internas do IFSC a partir de 1997, na época denominada ETFSC, com a reforma da educação profissional, trazendo a necessidade de (re)elaboração dos currículos dos cursos sob essa ótica (AMORIM, 2011).

Desde então, vê-se, dentro da instituição, opiniões favoráveis e contrárias a essa perspectiva de elaboração de currículos (AMORIM, 2011). A seguir, seguem algumas considerações sobre o termo competência relacionando-o à educação como um todo e à educação profissional.

\subsubsection{O Plano de Desenvolvimento Institucional do IFSC- PDI}

O Plano de Desenvolvimento Institucional, é o instrumento norteador das ações institucionais, destacado por Bertoldi (2006) como um documento institucional de caráter estratégico e que permite construir um retrato quantitativo e qualitativo da instituição. Neste caso, o PDI promove a consolidação de uma estrutura organizacional, contendo o "histórico da IES, sua implantação e evolução, descrição 
atual com dados quantitativos e qualitativos, estrutura organizacional e de gestão, objetivos e metas que pretende realizar no ensino, na pesquisa e na extensão" (BERTOLDI, 2006, p. 35).

No capítulo que trata da concepção do currículo, o Plano de Desenvolvimento Institucional do IFSC, aborda as competências de forma a justificar a escolha metodológica de concepção do currículo, "em consonância com os objetivos de inclusão e emancipação nos fundamentos educativos do IFSC, buscamos aprimorar como proposta um currículo interdisciplinar, que atende ao desenvolvimento das competências traçadas a partir de situações concretas das diferentes áreas profissionais, visando a promover a socialização dos saberes, superar a fragmentação entre as diferentes áreas do conhecimento e perceber o aluno como uma totalidade" (PDI, 2014).

$O$ documento traz também, a relação das diretrizes curriculares nacionais "referenciado na aprendizagem, o ensino organiza-se conforme as Diretrizes Curriculares Nacionais, especialmente para a educação profissional e tecnológica, construindo competências associadas aos perfis profissionais de formação de nossos cursos. No entanto, essas competências não podem se desvincular do caráter educativo desse processo, estimulando a prática, a pesquisa e a extensão como estratégias de ação" (PDI, 2014).

Outro aspecto importante e que merece destaque é no que se refere à definição e importância do ensino cujo texto reforça que "o ensino precisa considerar a aprendizagem, garantindo, além da atividade didática, a atividade pedagógica. Em outras palavras, não basta que haja ensino de qualidade, mas sim que efetivamente aconteça uma aprendizagem contextualizada, que garanta a construção de saberes e o aprimoramento humano do educando" (PDI, 2014).

Mais uma vez aparecem as competências na indissociabilidade do ensino, pesquisa e extensão. "(...) deve ser pensado em sintonia com a realidade do mundo atual, permitindo a formação continuada do trabalhador ao longo de sua vida, sem desconsiderar as competências e habilidades desenvolvidas na sua vivência diária" (PDI, 2014).

No capítulo que trata dos referenciais para elaboração dos projetos pedagógicos dos cursos o documento orienta que "os PPCs devem ser elaborados e implementados para a busca do desenvolvimento de competências - 
conhecimentos, habilidades e atitudes - dos sujeitos ${ }^{5}$, de forma coerente com as diretrizes da educação profissional e tecnológica, as diretrizes nacionais e demais documentos oficiais" (PDI, 2014).

\subsubsection{Regulamento Didático-Pedagógico do IFSC}

O Regulamento Didático-Pedagógico (RDP) é o documento único de gestão do processo educacional que estabelece as normas referentes aos processos didáticos e pedagógicos desenvolvidos por todos os campus do Instituto Federal de Educação, Ciência e Tecnologia de Santa Catarina (IFSC), suas modalidades e diversas ofertas.

A palavra competências aparece 20 vezes no documento como um todo. Em função de que o Instituto Federal trabalha em diversos níveis e modalidades de ensino, nem todas as ocorrências da palavra se referem aos Cursos Superiores de Tecnologia.

No que tange a abordagem das competências no referido documento, há de se considerar que não apresenta claramente qual a abordagem teórica o ensino por competências do IFSC se refere.

Merece destaque o Art. 16, parágrafo $5^{\circ}$ e o Art. 114:

Art. 16. O plano de ensino é o instrumento de planejamento das atividades para o período letivo e conterá: os objetivos ou competências, as metodologias e os instrumentos de verificação do aprendizado e a descrição das práticas, quando houver, incluirá também a bibliografia básica e complementar do componente curricular conforme PPC.

$\S 5^{\circ}$ A avaliação será realizada, em cada componente curricular, considerando os objetivos ou competências propostos no plano de ensino.

Art. 114. Os cursos de graduação serão organizados de acordo com as Diretrizes Curriculares Nacionais estabelecidas pelo CNE, com periodicidade semestral, em regime de matrícula por componente curricular. $\$ 1^{\circ}$. Poderão ser organizados por módulos didáticos, compreendidos como um conjunto de competências a serem desenvolvidas em um período letivo.

O documento norteia de modo detalhado a elaboração do plano de ensino, informando da necessidade de constar os objetivos ou competências.

Por último, o RDP traz ainda, um glossário, onde elencamos os verbetes e seus respectivos significados que se relacionam com o objeto desse estudo.

\footnotetext{
${ }^{5}$ Grifo da autora.
} 


\section{Quadro 7 - Glossário RDP}

\begin{tabular}{|c|c|c|}
\hline Verbete & Categoria & Definição \\
\hline Bacharelado & Ensino & $\begin{array}{l}\text { Curso superior generalista, de formação científica ou humanística, que } \\
\text { confere ao diplomado competências em determinado campo do saber } \\
\text { para o exercício de atividade profissional, acadêmica ou cultural, com } \\
\text { o grau de bacharel. }\end{array}$ \\
\hline $\begin{array}{l}\text { Certificado } \\
\text { Intermediário }\end{array}$ & Ensino & $\begin{array}{l}\text { Documento com validade em todo o território nacional, que atesta a } \\
\text { conclusão de uma etapa do curso, conferindo competências } \\
\text { profissionais específicas, o mesmo que saída intermediária. }\end{array}$ \\
\hline $\begin{array}{l}\text { Currículo do } \\
\text { Curso }\end{array}$ & & $\begin{array}{l}\text { Programa de estudos que objetiva atender os objetivos, competências } \\
\text { e demais especificidades previstos no Projeto Pedagógico do Curso, } \\
\text { cuja finalização conduz à certificação. }\end{array}$ \\
\hline $\begin{array}{l}\text { Módulo } \\
\text { didático }\end{array}$ & Ensino & $\begin{array}{l}\text { Agrupamento de componentes curriculares de um curso para a } \\
\text { construção de um conjunto específico de competências, independente } \\
\text { do regime de matrícula, da forma de oferta ou da modalidade }\end{array}$ \\
\hline $\begin{array}{ll}\text { Perfil } & \text { do } \\
\text { egresso } & \\
\end{array}$ & Ensino & $\begin{array}{l}\text { Conjunto de competências e características que compõem o perfil } \\
\text { profissional de um aluno que concluiu um curso. }\end{array}$ \\
\hline $\begin{array}{l}\text { Projeto } \\
\text { Integrador }\end{array}$ & Ensino & $\begin{array}{l}\text { Estratégia de ensino que objetiva proporcionar ao discente a } \\
\text { interdisciplinaridade dos temas desenvolvidos ao longo do curso, } \\
\text { fornecendo subsídios para a avaliação das competências } \\
\text { desenvolvidas ao longo do período letivo. }\end{array}$ \\
\hline $\begin{array}{l}\text { Projeto } \\
\text { Pedagógico } \\
\text { do Curso } \\
\text { (PPC) }\end{array}$ & Ensino & $\begin{array}{l}\text { Documento que traz informações pedagógicas sobre o curso e fornece } \\
\text { diretrizes de como ele será executado. Dentre as informações } \\
\text { constantes em um PPC, estão os objetivos do curso, a } \\
\text { contextualização social, a discriminação de todos os componentes } \\
\text { curriculares (matriz curricular), com suas cargas horárias, } \\
\text { competências e conteúdo programático, e o perfil profissional do } \\
\text { egresso. }\end{array}$ \\
\hline Tecnólogo & Ensino & $\begin{array}{l}\text { Curso superior de formação especializada em áreas científicas e } \\
\text { tecnológicas, que confere ao diplomado competências para atuar em } \\
\text { áreas profissionais específicas, caracterizadas por eixos tecnológicos, } \\
\text { com o grau de tecnólogo. }\end{array}$ \\
\hline
\end{tabular}

O IFSC esclarece por meio do glossário, as definições de cada modalidade, e como as competências dialogam com elas. O termo competência aparece repetidas vezes, o que confirma toda iniciativa contida nos documentos do IFSC sobre a educação/ensino por competências.

\subsubsection{O tema Empreendedorismo no IFSC}

No plano da atual gestão, Maria Clara Reitora 2015-2019, que estará à frente do IFSC até o ano de 2019 o empreendedorismo foi citado como ação de destaque 
no âmbito da atuação da Pró-reitora de Pesquisa e Pós-Graduação, conforme é possível ler a seguir:

1) Realizar eventos, capacitações e parcerias com instituições de apoio e fomento ao empreendedorismo ${ }^{6}$;

2) Incentivar e fomentar iniciativas empreendedoras de alunos por meio de programas internos;

3) Realizar parcerias com incubadoras e demais atores da cadeia de inovação, incentivando a criação de novas empresas e ampliação das oportunidades de emprego e renda do egresso;

4) Incentivar ações de economia solidária e economia criativa.

Como se pode observar, o tema Empreendedorismo está evidenciado na política da atual gestão, o que demonstra a importância da temática para a instituição e para os gestores. Nesse sentido, considerando o ensino de empreendedorismo, a partir da abordagem de gestão por competências no IFSC, o currículo é "interdisciplinar, que atende ao desenvolvimento das competências traçadas a partir de situações concretas das diferentes áreas profissionais, visando a promover a socialização dos saberes, superar a fragmentação entre as diferentes áreas do conhecimento e perceber o aluno como uma totalidade" (PDI, 2014).

Os componentes curriculares são em módulos e cada módulo prevê o desenvolvimento de competências. Essa organização está orientada pelas diretrizes e pelos documentos oficiais da instituição.

O Instituto Federal de Santa Catarina por meio do seu documento de planejamento, o Plano de Desenvolvimento Institucional - PDI, orienta sucintamente a forma de elaboração dos PPCs. Inicialmente a orientação esclarece que os PPCs devem ser concebidos respeitando "as mesmas concepções de educação, ensino, pesquisa, extensão e gestão que permeiam todas as atividades da instituição, respeitando as peculiaridades de cada oferta educativa" (PDI, 2014).

O documento aponta ainda que "os PPCs devem ser elaborados e implementados para a busca do desenvolvimento de competências - conhecimentos, habilidades e atitudes - dos sujeitos, de forma coerente com as diretrizes da educação

${ }^{6}$ Grifo da autora. 
profissional e tecnológica, as diretrizes nacionais e demais documentos oficiais" (PDI, 2014).

O termo Empreendedorismo aparece no projeto do curso superior de hotelaria, nos objetivos gerais e específicos, fazendo menção à "formação crítica e Empreendedora". No item que menciona as competências profissionais é dada luz à questão da necessidade de aplicação dos conceitos de empreendedorismo sob a ótica da operação e na concepção do novo negócio, limitando mais uma vez o conceito, às questões empresariais. Observa-se ainda que no projeto o componente curricular aparece de maneira isolada no 5올 semestre.

Já no PPC do Curso Superior de Tecnologia em Gastronomia, o termo empreender aparece nas ementas de dois componentes curriculares, gastronomia brasileira e empreendedorismo, enquanto que no PPC do CST em Hotelaria o termo aparece somente no componente curricular de Empreendedorismo. 


\section{CAPÍTULO 3 - ABORDAGEM METODOLÓGICA}

Tendo em vista o objetivo da pesquisa e a problemática proposta, foi organizada uma pesquisa com abordagem qualitativa (BICUDO, 1997; TRIVIÑOS, 1987; GIL, 1994), que é o tipo de pesquisa que os pesquisadores estão interessados em compreender o significado que as pessoas construíram sobre determinado conceito ou realidade. Considerou-se que essa abordagem respondia adequadamente ao problema de pesquisa proposto.

A abordagem qualitativa se presta ao tipo de estudo sobre opiniões, valores ou crenças de determinado grupo, ou seja, mostra-se hábil para compreender a realidade de forma mais completa. Neste sentido, Dal-Farra e Lopes (2013, p. 71) enumeram as vantagens da abordagem qualitativa:

a capacidade de gerar informações mais detalhadas das experiências humanas, incluindo suas crenças, emoções e comportamentos, considerando que as narrativas obtidas são examinadas dentro do contexto original em que ocorrem. Além disso, [...] proporcionam análises profundas das experiências humanas no âmbito pessoal, familiar e modelos variados.

Quanto ao instrumento para a coleta de dados, foi utilizado o questionário não estruturado (BARBETTA, 2004).

\subsection{Questão-problema}

Qual o entendimento do(a/s) docente e discentes dos cursos superiores de tecnologia do IFSC campus Florianópolis-Continente sobre a contribuição do componente curricular de Empreendedorismo para a intenção em empreender? 


\subsection{Sujeitos da Pesquisa}

A coleta de dados foi realizada com a docente que ministrou o componente curricular e discentes que cursaram o componente curricular de Empreendedorismo do Instituto Federal de Santa Catarina Campus Florianópolis Continente. Para compor a amostra, os alunos deveriam ter cursado, com aprovação, o componente curricular de Empreendedorismo nos cursos de Gastronomia e Hotelaria.

\subsection{Amostra}

Considerando o universo pesquisado de duas turmas, quais sejam Hotelaria e Gastronomia, cujos alunos cursaram o componente curricular de Empreendedorismo e que por sua vez trata-se de um público heterogêneo, do ponto de vista da idade, formações anteriores e experiências profissionais existentes ou não, observou-se na escolha do tipo de amostragem, que esta não seria probabilista, pois não fazendo uso de formas aleatórias de seleção, torna-se impossível a aplicação de fórmulas estatísticas para o cálculo, por exemplo, entre outros, erros de amostra (MARCONI e LAKATOS, 2008).

Dito de outro modo, não podem ser objetos de certos tipos de tratamento estatístico. Utilizando do tipo de amostra não probabilista optou-se ainda pela amostra intencional, onde o pesquisador está interessado na opinião (ação, intenção etc.) de determinados elementos da população, mas não representativos dela. O pesquisador se dirige àqueles que, segundo seu entender, pela função desempenhada, cargo ocupado, prestígio social, exercem as funções de líderes de opinião na comunidade" (idem). Neste estudo a amostra foi de onze alunos, que cursaram o componente curricular de empreendedorismo no segundo semestre de 2015. Os alunos se encontravam na seguinte classificação por curso: a) só estuda, b) trabalha na área, c) trabalha fora da área, d) empreende na área do curso, e) empreende fora da área do curso.

Com relação a docente pesquisada, contatou-se a docente que ministrou o componente curricular de Empreendedorismo para as turmas de Hotelaria e 
Gastronomia, que possuía vínculo de professora substituta, cuja atuação se deu nas duas turmas.

Tabela 1 - Estudantes dos cursos de Gastronomia e Hotelaria

\begin{tabular}{|c|c|c|c|}
\hline \multicolumn{4}{|c|}{ ESTUDANTES DOS CURSOS SUPERIORES DO IFSC CFC } \\
\hline Curso & Período & Módulo & Matriculados \\
\hline Gastronomia & Matutino & 5 & 21 \\
\hline Hotelaria & Matutino & 5 & 23 \\
\hline
\end{tabular}

Optou-se por esse perfil de aluno por se entender que o aluno que concluiu o componente curricular possui experiências que aqueles que ainda estão cursando ainda não possuem. A escolha deste público se justifica em virtude de ambos os cursos não terem egressos e a unidade curricular de empreendedorismo ser lecionada no $5^{\circ}$ período.

\subsection{Instrumento de coleta de dados}

A coleta de dados foi realizada junto aos alunos e professora de Empreendedorismo do IFSC, por meio de um questionário com questões abertas (APÊNDICE A). O questionário aplicado aos alunos era composto por vinte e uma questões. O link do instrumento foi enviado via aplicativo whatsapp, construído no google docs.

\subsection{A coleta dos dados}

A coleta de dados ocorreu no mês de março de 2016. Para tanto, buscou-se nas coordenações dos cursos de Gastronomia e Hotelaria, os alunos que 
correspondiam ao perfil desejado, solicitando a listagem dos alunos que haviam concluído o componente curricular com aprovação e o contato dos mesmos.

Os alunos e a professora mostraram-se bastante receptivos à pesquisa e responderam prontamente aos questionários.

\subsection{Análise dos dados}

A análise dos dados foi realizada considerando-se as colocações dos participantes e o referencial bibliográfico que dá suporte a este trabalho, buscando desenvolver reflexões acerca das tendências e contradições presentes nas respostas dos participantes.

\subsection{Aspectos éticos}

Quanto às implicações éticas envolvidas na pesquisa, os participantes foram informados sobre seu objetivo e foi colocado número de telefone e e-mail a disposição para esclarecimento de dúvidas, tanto sobre a pesquisa, quanto sobre o instrumento de coleta de dados, assim como será garantido o acesso aos resultados obtidos, se assim desejarem.

A realização da pesquisa foi autorizada pela instituição e os instrumentos de coleta de dados foram revisados e autorizados pelos responsáveis. Já quanto a privacidade dos participantes, está garantida, pois os questionários foram respondidos pelos alunos anonimamente e a professora também terá seus dados preservados. Ademais, os dados obtidos foram utilizados única e exclusivamente para execução da presente pesquisa. 


\section{CAPÍTULO 4 - COMO DOCENTE E DISCENTES COMPREENDEM A FORMAÇÃO EM EMPREENDEDORISMO NO IFSC}

Os dados ora apresentados são resultantes da coleta realizada junto aos alunos do IFSC. A partir de uma análise dos dados disponíveis, buscou-se interpretálos e relacioná-los à bibliografia estudada e aos autores que deram suporte a este estudo. Algumas falas dos alunos foram transcritas para melhor explicar o que vai sendo discutido e apresentado ao longo do capítulo.

\subsection{Caracterização dos sujeitos}

Participaram da pesquisa: a professora do componente curricular de Empreendedorismo, a qual é professora substituta, com tempo de docência de um ano e meio no IFSC. Sua área de formação é Administração Pública, com Mestrado em Arquitetura e Urbanismo pela UFSC, ênfase em Desenvolvimento Regional. Sobre a experiência da professora com empreendedorismo, ela relata que não possuía nenhuma até $o$ trabalho com os discentes no componente curricular e que seu contato com o mundo empresarial foi na família:

[...] meu pai tinha uma empresa quando eu era muito nova e eu trabalhava com ele até mais ou menos 2005, mas nada de muito diferente, foi na época de empresas de 1,99 que surgiram no Brasil inteiro, a gente abriu uma loja do mesmo nível, e eu tinha menos de 10 anos de idade, a única experiência (Professora).

Já sobre a formação específica da professora em Empreendedorismo, ela relata que realizou apenas um curso de empreendedorismo, em 2011.

Fiz um curso de empreendedorismo em 2011 pela Aliança Empreendedora, que é uma organização não governamental de Curitiba, que incentiva o empreendedorismo. Foi um curso de um mês mais ou menos, e eles têm a metodologia própria de empreendedorismo para o ensino. [...] Depois, com base nesse curso, eu dei um outro curso de empreendedorismo para 
agricultores. A única formação com certificado. E alguns cursos do Sebrae mas não conta nem como certificado, aqueles EaD que eu acho que é mais para quem não tem conhecimento nenhum do que pra quem já possui um conhecimento (Professora).

Quanto aos alunos, participaram da pesquisa 11 alunos matriculados nos cursos de Gastronomia e Hotelaria, todos eles aprovados no componente curricular de Empreendedorismo, ministrado no quinto semestre do curso. Dos participantes, 8 são mulheres e 3 são homens, indicando para a maior participação da mulher nos cursos de nível superior, o que já foi apontado por Zabalza (2004) como importante, pois colabora para a igualdade de direitos entre homens e mulheres, bem como para a diferenciação dos níveis de sensibilidade nas relações interpessoais dentro da instituição.

A idade dos participantes varia de 23 a 51 anos, sendo predominante a faixa etária entre 40 e 50 anos. Isso indica que, apesar de a maioria dos estudantes ingressarem na universidade muito jovens, o perfil dos alunos de cursos de tecnologia pode ser um pouco diferente, o que encaminha para a necessidade de se adotarem metodologias e práticas apropriadas à faixa etária e ao perfil do discente, o qual pode já ter outras obrigações que os mais jovens não possuem, tais como trabalhar para manter a casa, cuidado com filhos etc.

Essa informação pode ser relevante, principalmente porque a maioria dos participantes (9) afirmou trabalhar atualmente. Nesse sentido, não só práticas que sejam flexíveis, como atividades a distância, por exemplo, mas também atividades que proporcionem relação entre a atuação profissional e a formação são essenciais. Ademais, considerando-se a faixa etária, práticas de educação de adultos são necessárias para que as competências propostas sejam alcançadas (AQUINO, 2007).

Considerando, ainda, o proposto por Abreu e Masetto (1990), as práticas que considerem a experiência da vida dos aprendizes e com atividades centradas em problemas relevantes para suas vidas são mais significativas, podendo orientar para uma mudança de comportamento, focada em objetivos reais, desde que forneçam feedback e bom relacionamento interpessoal.

Dos alunos que afirmaram que trabalham, 5 destacaram trabalhar na área que estão realizando a formação atualmente, sendo que aqueles que realizam formação 
em hotelaria afirmam estar atuando na rede hoteleira, e aqueles que cursam gastronomia administram e/ou trabalham em restaurantes.

Quanto ao vínculo empregatício, 5 alunos também são os que não possuem vínculo empregatício, são freelancers, sócios de empresas ou atuam como microempreendedor individual.

\subsection{O olhar discente sobre suas experiências com empreendedorismo}

Questionados se já tiveram alguma experiência com empreendedorismo, daqueles que afirmaram que sim, mencionaram o contato em atividades da família: "meus pais e meu irmão são empreendedores" (P2); no negócio próprio: "na própria pousada, inovando serviços, abrindo um bar para servir na praia" (P3); na iniciativa de vender algo: "iniciei a venda de cupcakes através de redes sociais" (P5); e na atuação como gerente e/ou consultorias: "somente com consultorias e assessorias" (P4), "já gerenciei uma loja" (P9).

Os alunos foram questionados também se o empreendedor "nasce pronto" ou se desenvolve ao longo da vida. As respostas dos alunos indicaram que o empreendedor tanto nasce com características que facilitam seu desenvolvimento empreendedor, quanto podem, a partir dessas características, se desenvolverem. Os participantes relataram:

Acredito que existam os dois tipos. Existem empreendedores natos, que, sem formação alguma, montam uma empresa e, com suas habilidades e muita dedicação, conseguem prosperar. Temos inúmeros exemplos que comprovam isso. Já outros precisam se especializar, conhecer melhor o mercado, desenvolver competências empreendedoras, que os deixem preparados para ter seu próprio negócio (P1).

Se desenvolve, visto que as experiências adquiridas é que servirão de base para o empreendedor. Entretanto, é perceptível que certas pessoas possuam mais 'tino' para os negócios que outras (P4). 
Acredito que se desenvolva ao longo da vida, embora algumas características de personalidade possam contribuir para a formação do empreendedor (P10).

Nenhum dos participantes demonstrou acreditar que o empreendedor nasce pronto, que empreender é algo que se nasce sabendo. 2 alunos acreditam que o empreendedor se desenvolve ao longo da vida e outros 2 alunos acreditam que a necessidade leva a empreender. Esses participantes argumentaram que 0 empreendedor:

Se desenvolve a partir da forma como a pessoa é educada pela família, depois com as necessidades da vida (P2).

Nenhuma das duas necessariamente. Existem os empreendedores por natureza que, desde muito jovens, procuram criar oportunidades de negócios, e aqueles que empreendem por necessidade, preferindo a solidez de um emprego fixo, mas tendo que empreender em razão de circunstâncias imprevistas, como o desemprego (P5).

Ainda que os participantes acreditem que é possível aprender a empreender, muitos se referem a dom, características natas, "tino", o que reflete a crenças acerca da temática (KOTLER e KELLER, 2012). Contudo, é sabido que se aprende a empreender (SOUZA, 2005) e que é possível desenvolver competências empreendedoras, por meio do aprender a aprender, a ser, a fazer e, principalmente, a conviver.

Alguns participantes da pesquisa relataram que a necessidade, além das características natas e dos aspectos sociais, leva a pessoa a empreender. Visto de modo simplista, isso diminui o conceito de empreendedorismo ligado ao mero constituir uma empresa, vender algo, comércio de algum produto ou serviço que gere renda.

Questionados se empreender é algo resultante de oportunidade ou de necessidade, 10 participantes acreditam que ambas influenciam na atividade empreendedora. Porém, suas justificativas apontam mais para a necessidade como estímulo:

Acredito que sim. A crise faz com que as pessoas sejam criativas para poderem crescer. Situações como a perda do emprego faz com que as pessoas busquem outra alternativa para sair deste 
momento ruim, muitos empreendedores acabam se descobrindo desta forma. Estas pessoas veem uma oportunidade de crescer diante da dificuldade, o ideal é que busquem ajuda especializada (Ex: Sebrae), pois não estão habituados com as atividades que gerir uma empresa requer (P1).

A crise nos movimenta, e oportunidade mais coragem pode gerar sucesso"(P2).

Com a economia abalada como está, do ano passado para esse, os menos preparados estão 'quebrando'. Então, se aproveitou do momento para tentar atender essa demanda que será aberta pelos que estão deixando o mercado (P4).

É necessário estar atento ao mercado para fazer as modificações e melhorias de acordo com as mudanças (P9).

Um aluno destacou a família como influente:

Se desde pequeno você estiver vinculado a negócios com a sua família, por exemplo, depois de adulto terá mais visão e coragem para empreender nos próprios negócios (P2).

Outro mencionou, ainda, o dom como elemento central:

Existe também aquele que tem o dom, e empreende naturalmente (P6).

Sobre o componente curricular de empreendedorismo, cursado no $5^{\circ}$ período, os alunos consideraram a experiência: muito interessante, muito rica, adequada, importante, superimportante, muito importante, muito proveitosa, fundamental, ótima. Os alunos afirmaram que:

Foi muito interessante. Recebemos um conteúdo muito completo, com caracterização de empreendedores etc. Eu não conhecia o método Canvas, estava habituada a técnicas mais antigas e achei muito interessante, nosso grupo interagiu bastante e o trabalho fluiu muito bem (P1).

Muito rica. Pois percebemos os tipos, níveis e perfis de empreendedor. Ex. Pode ser um empreendedor dentro da própria empresa onde trabalha, com uma simples mudança interna. Metodologicamente falando, foi excelente, pois tivemos 
palestras, visitas ao mundo empreendedor e isso, com certeza, instigou todos a desafiar seus próprios limites de empreendedor (P2).

Carga horária foi boa, pois, mesmo sem tempo para abordar à fundo os aspectos empreendedor, tivemos uma visão boa do assunto tratado, e também o curso é voltado mais para área hoteleira, serviços (P3).

A disciplina foi importante à medida em que disponibilizou oportunidade de conhecimento de diversas formas de empreendedorismo, suas bases e fundamentos técnicos capazes de auxiliar na ação empreendedora, como, por exemplo, o método Canvas. Tanto a bibliografia quanto a carga horária se demonstraram compatíveis com o objetivo da disciplina e as atividades propostas (visitas técnicas, palestras, participação em congressos do meio empreendedor) enriqueceram muito o conteúdo da disciplina (P6).

Superimportante para o processo de ensino e aprendizagem do aluno. Norteia e encoraja aquele que deseja empreender e mostra o mundo do empreendedorismo para quem desconhece (P7).

Foi muito importante. Na verdade, o quinto período foi de grande valia em minha vida. Vi e vejo tudo que aprendi na academia e, como empreendedora, tento, ao máximo, utilizar tudo que aprendi na disciplina de Empreendedorismo, como na disciplina de Marketing e gestão de qualidade e inovação. Acho até que poderia ser em um ou dois período antes, pois aguçar esse espírito empreendedor na academia é muito válido, mas no quinto período também foi ótimo por já estar tudo muito pesado, a disciplina corre de maneira mais leve. Poderia ter mais carga horária, tenho dificuldades para as questões mais minuciosas como a abertura de empresas e a parte de legalização (P8).

Acredito que a disciplina é de extrema importância para o curso, pois possibilita ao aluno vivenciar casos e aprender como se tornar um empreendedor, como gerenciar uma empresa, como atingir o sucesso (P10).

Já sobre a contribuição do componente curricular de Empreendedorismo na sua intenção de empreender ou não, 8 alunos mencionaram que o componente curricular contribuiu com a intenção de empreender, afirmando: 
Tenho uma afinidade muito grande com o empreendedorismo, acredito que a disciplina contribuiu bastante para que eu aperfeiçoasse o método como faria isso. Com certeza, se fosse abrir uma empresa utilizaria o Canvas para verificar as necessidades do negócio. Infelizmente, devido a situação atual do país, principalmente a elevada carga tributária e as dificuldades que os empreendedores estão passando, não tenho interesse algum em abrir meu próprio negócio, mas não descarto, caso, no futuro, o país valorize mais o empreendedor (P1).

Antes não tinha noção do tema. Hoje conheço técnicas, riscos e necessidades para empreender (P2).

O conhecimento de técnicas administrativas e bases de empreendedorismo se mostraram fundamentais na formulação das ideias e no embasamento para o sucesso destas, modificando a forma de pensar e planejar (P5).

Houve contribuição com o fortalecimento do desejo. A disciplina apresentou teoria e prática tão importantes para o conhecimento (P6).

Meu espírito empreendedor estava sem foco e sem estímulo para o meu negócio, depois do quinto período comecei a empreender mais e a entender o meu cliente. Hoje empreendo em meu próprio empreendimento e estimulando e ajudando meus filhos a empreenderem, já que, muitas vezes, a oportunidade aparece e temos que aproveitar (P7).

A disciplina contribuiu para o meu crescimento pessoal e profissional, abrindo perspectivas e ordenações ao empreendedorismo (P8).

Sim, pois vi muitos casos que deram certo. Pequenas empresas se tornando multinacionais, empreendedores tendo lucros extraordinários (P9).

Porque apresentou possibilidades e técnicas que eu desconhecia (P10).

Já 2 alunos afirmaram que o componente curricular não contribuiu com a intenção de empreender e uma aluna afirmou que não sabia responder, mas que serviu de "estímulo para os filhos e o marido" (P3). 
As colocações dos participantes remetem muito à questão financeira, empresarial, a ter o negócio próprio, gerenciamento do negócio etc. Contudo, empreendedorismo transcende o envolvimento empresarial. Ser empreendedor é mais do que criar novos negócios, novos produtos, novas oportunidades, é um estilo de vida, uma decisão de vida. Decisão de agir, de buscar a felicidade, a sua realização pessoal, seus sonhos de tomar em suas mãos as rédeas da sua vida e do seu destino e, ao tomar essa atitude, tem como consequência o sucesso pessoal e profissional (CONSONI apud SOUZA, 2012).

Questionados se se consideram motivados a empreender após cursar o componente curricular de empreendedorismo, 8 participantes destacaram que sim. Alguns mencionaram que a economia atual não estimula, mas que a aprendizagem foi importante para pensar no futuro. Já três alunos afirmaram que não se sentem motivados a empreender.

Quanto à área em que se sentem mais motivados em empreender, os participantes destacaram a motivação em empreender em suas áreas de formação: Gastronomia e Hotelaria. Alguns mencionaram a experiência e a formação para seguir na área:

A área mais motivadora é a área de gastronomia, tanto em razão do curso realizado quanto em função do crescimento constante da área de alimentação fora do lar (P5).

Alimentos e Bebidas. Por atuar há mais de 10 anos como barman e por possuir afinidade com as características que envolvem a área (P6).

Na gastronomia. Por ser minha área e perceber que há muitas oportunidades (P11).

Sobre a experiência empreendedora dos participantes, 5 alunos relataram que já empreenderam em algum momento e contam um pouco da sua história de fracassos e sucessos:

Comecei a empreender por querer viver em Florianópolis, e abri o segundo hostel da cidade, na praia da Costa de Dentro. Com o dinheiro que ganhei, abri uma pousada na Armação e depois outra na beira da praia, a que eu trabalho até hoje... Aprendi tudo 
na vivência e agora, com os cursos, estou profissionalizando (P3).

Até o momento, os resultados estão dentro do esperado. Mas penso que todos os cursos de gestão necessitam ter uma disciplina, como 'leis e obrigações legais nacionais, estaduais e municipais', que aborde assuntos como obtenção de alvarás e obrigações legais e tributárias, de acordo com o porte da empresa (P4).

A experiência começou com a produção de cupcakes para familiares e amigos. Logo, fui incentivada a criar uma página em rede social para aceitar encomendas, em seguida, um site para pedidos e a venda direta e oferecimento dos produtos em site de venda coletiva. Infelizmente, não há possibilidade de dedicação exclusiva ao empreendimento, mas o crescimento dele, apenas com o uso das mídias sociais e eletrônicas, é surpreendente e demonstra a capacidade de crescimento do negócio" (P5).

"Aos 17 anos iniciei meu próprio negócio, vendendo cigarros do Paraguai para bares da cidade onde morava. O negócio não deu muito certo, voltei a trabalhar com carteira assinada, quando, aos 24 anos, montei um pequeno negócio de bares para eventos com dois amigos. Esse negócio hoje é tocado por mim e minha esposa, ainda de maneira informal, com versões de bares itinerantes para rua, praia e eventos. Este projeto ficou parado por quase 6 anos e há 2 retomamos o projeto (P6).

Sou uma empreendedora nata, mas também empreendi por necessidade. Desde nova já possuo meu negócio próprio, pois assim tenho mais autonomia na minha vida e faço meus horários. Minha primeira experiência foi com loja de roupas, e aprendi muito, busquei usar recursos próprios e, no início, tive ajuda de meu pai. E a segunda, como Cabeleireira, procurei recursos com procura de uma sociedade e foi muito gratificante dividir com alguém toda a responsabilidade. Hoje continuo com o Salão de Beleza, mas não paro de pensar em algo novo, mas tento me acalmar, pois gosto muito do que faço; e vi, no decorrer do curso, que estava mais certa disso, por isso hoje estimulo muito minha filha a empreender (P7).

Já os 6 alunos que afirmaram que não empreendem dizem que não o fazem pelos seguintes motivos: falta de otimismo, insegurança econômica do país, não saber qual segmento, falta de necessidade financeira, falta de coragem, falta de recursos financeiros, ter emprego público e falta de conhecimento específico.

Algumas colocações dos alunos deixam isso mais claro: 
Não me considero empreendedora nata, mas já adquiri bastante conhecimento sobre empreendedorismo, acho que o que falta é um pouco mais de otimismo diante da insegurança que vivemos em nosso país e também encontrar a ideia que faça 'meus olhos brilharem', pois vejo o empreendedorismo muito ligado com amor ao seu negócio e ao que você faz (P1).

Eu costumo melhorar processos dentro do meu trabalho. Mas empreender para mim profissionalmente não tenho coragem. Eu optei por estudar nos últimos 5 anos, fiz um curso técnico e um superior. E também, o que eu ganho me deixa um pouco na zona de conforto. Assim, não vejo necessidade para o tema (P2).

Se acreditam que o componente curricular de empreendedorismo (currículo, bibliografia, metodologia, carga horária etc) é suficiente ou não é suficiente para motivá-los a empreender, 2 participantes destacaram que o componente curricular não é suficiente. Sendo que um destaca:

Para a motivação sim, se esse for o intuito; mas para empreender não, pois há necessidade de muito mais para um empreendedor. Elaboração de Plano de negócios, abertura de empresas, legalização, apesar de ser dado, acho que não é o suficiente (P7).

Já 9 participantes afirmaram que o componente curricular surpreendeu positivamente, é suficiente, maravilhoso e ajuda muito a quem quer empreender. Em suas colocações pode-se ler:

A disciplina cumpre seu papel, até me surpreendeu positivamente. Eu já havia cursado esta disciplina no curso de Administração de Empresas e percebi bastante diferença na maneira com que foi abordada a temática, buscando motivar o aluno, ensinar de fato as ferramentas (considero que o professor tenha papel fundamental neste ponto). Acho que a disciplina pode, sim, despertar o interesse do aluno em empreender, mas o que define se ele fará será o mercado, suas ideias e o capital que ele deve ter para investir, tendo em vista a grande dificuldade de conseguir bons financiamentos em nosso país (P1).

Sim, é suficiente. Mas veja bem, empreender não depende do professor, nem da carga horária, e sim da necessidade e coragem para se sentir motivado. O curso é para trabalhar em hotéis e não para formar empresas... No caso de empreender 
dentro da empresa, a minha resposta é sim. Motiva, sim, a melhorar as atividades no trabalho (P2).

Tivemos algumas aulas com métodos práticos que foram maravilhosos e que poderiam ser com o tempo maior; a viagem para conhecer a vivência das pessoas empreendedoras e 0 resultado é motivador (P3).

A disciplina de empreendedorismo se demonstra suficiente como motivação e embasamento para empreender, considerando-se sempre a necessidade de maior aprofundamento para, efetivamente, aplicar os conhecimentos adquiridos na prática (P5).

Sim, pois é necessário ter conhecimento prévio de ordem administrativa a qualquer empreendimento (P8).

Acho que é suficiente para dar o start no aluno (P10).

Questionados sobre as iniciativas realizadas pelo IFSC, importantes para a aprendizagem de empreendedorismo, ou se não há atividade realizada pelo IFSC que contribua, os participantes (6 alunos) mencionaram que há o componente curricular de empreendedorismo e outros que permitem conhecer melhor a futura área de atuação, como visitas técnicas, eventos, palestras e pesquisas. Suas falas deixam mais claros seus pontos de vista:

Nossa, muitas. Visitas técnicas, cooperativas, trabalho individual, pesquisas (P2).

Visitas técnicas, participação em eventos, palestras com profissionais (P6).

Visitas técnicas, eventos, pessoas influentes sempre em contato com a instituição (P9).

Contudo, o mais destacado pelos participantes é a atuação dos professores e suas iniciativas individuais. Alguns participantes (5 alunos) reforçam isso afirmando que não há muitas iniciativas e/ou iniciativas formais por parte da instituição, mas sim dos docentes, de forma individualizada. 
No momento, recordo apenas da disciplina de empreendedorismo e, claro, das outras disciplinas do curso que dão embasamento para o empreendedor conhecer melhor a área que deve procurar empreender e o funcionamento de uma empresa (P1).

Acho que a iniciativa parte mais dos professores do que do instituto, que, sem dúvida, nos dá uma estrutura tremenda (P3).

As atividades realizadas, em sua maioria, são de iniciativa dos professores, portanto, não há iniciativas da instituição que contribuam para a aprendizagem (P5).

Sobre a relevância dessas iniciativas, os alunos destacaram a aproximação com a realidade de trabalho, o incentivo à abertura do próprio negócio, as vivências além sala de aula e a abertura para o mercado. Eles mencionaram que são relevantes, afirmando que:

Colocar o aluno mais próximo da realidade do mercado o faz enxergar a coisa de maneira mais consciente e clara (P6).

Na verdade, eu vejo, na grande maioria dos alunos de cursos técnicos do IFSC, um perfil empreendedor, e o Instituto sempre busca mostrar a realidade no mercado de trabalho, seja para empreender como para trabalhar em empresas já constituídas. Mas incentivar mais os alunos em relação à abertura do seu próprio negócio nunca é demais, e oferecer mais recursos financeiros para ser trabalhado com os alunos em ambientes fora da academia (P7).

Propiciar vivências aos alunos (P8).

Abrir portas para o mercado (P9).

Já sobre iniciativas no IFSC, importantes para incentivar a abertura de empresas ou a criação de novos produtos na área do curso, alguns alunos afirmaram que desconhecem a existência. Eles destacaram que:

Pelo menos na parte de Hotelaria, não me recordo de nenhuma iniciativa (P1). 
O IFSC nos prepara para ser empregado não para empreender (P3).

As iniciativas de criação de novos produtos estão basicamente ligadas à produção e tecnologia de alimentos, mas não recebem apoio no sentido de comercialização ou criação de empresas (P5).

Já 4 participantes afirmaram que há iniciativas. Alguns relataram que:

Sim. Trabalhos em grupos, trabalhos e pesquisas em inovação. Concursos com premiações... (P2).

Sim. O trabalho de conclusão da disciplina pede um plano de negócios para a criação de um produto inovador na hotelaria (P6).

A oferta de cursos de qualificação, já faz um tempo, pelo menos que eu procuro curso que me interesse e não encontro no IFSC; estimular mais a procura de órgãos como o SEBRAE para auxiliar, dar essa conexão mais facilmente entre a Instituição, aluno e o SEBRAE; uma assessoria para as dúvidas dos alunos em relação ao assunto $(\mathrm{P} 7)$.

Grupos de estudos e as visitas técnicas (P8).

Essa polaridade nas afirmações pode indicar que, se essas iniciativas existem, não são muito divulgadas ou os alunos não as entendem como iniciativas que realmente estimulem a abertura de empresas e a criação de novos produtos. Contudo, as iniciativas adotadas pela professora do componente curricular parecem importantes para os alunos, para mostrar o empreendedorismo na prática, uma vez que somente a teoria e o trabalho realizado em sala de aula podem não ser suficientes para dar conta da amplitude e da quantidade de conhecimentos envolvidos. 


\section{3 o olhar docente sobre as experiências oferecidas aos alunos no componente} curricular de empreendedorismo

A professora que ministrou o componente curricular foi entrevistada sobre vários aspectos de sua experiência, sua prática na disciplina e fora dela, bem como sua opinião sobre o incentivo da disciplina para os alunos.

Sobre a metodologia utilizada para ministrar o componente curricular de empreendedorismo, a professora relatou que parte da carga horária foi de aulas expositivas e dialogadas e parte de eventos, visitas técnicas com os alunos, palestras de consultoria, pesquisas diversas.

Já sobre a formação pedagógica em ensino por competências, a professora relatou que não possuía nenhuma formação. Diz ela que "a única coisa foi no dia que eu entrei no IFSC, me falaram isso é o ensino por competências, em uma hora e deu".

Especificamente sobre o componente curricular de empreendedorismo (currículo, bibliografia, metodologia, carga horária etc.), presente no currículo dos CST do IFSC, campus Florianópolis - Continente, perguntou-se à professora se ela acreditava ser ou não suficiente para motivar o discente a empreender. Segundo ela, o componente curricular não é suficiente, porque está muito focado na sala de aula e não possui carga horária prática, uma vez que, para montar planos de negócio, por exemplo, é necessária a prática, não é algo que se faça somente em sala de aula:

Eu acho que ela não é suficiente porque foi montada num molde muito sala de aula, o que não é bom para o empreendedorismo. Acho que tem que ter um viés prático mais forte, tanto que era pra montar um plano de negócios formal e tu dá toda a história de empreendedorismo, todas as questões de índice que existem e mais montar um plano de negócios. Pra montar um plano de negócios formal, não se monta dentro da sala de aula e nem só com uma disciplina. Para montar um plano de negócios, tem que ser um projeto integrador, que daí teria que entrar marketing e custos, que não cabe na disciplina de empreendedorismo dar tudo isso, ou revisar esses conteúdos [...]

[...] a carga horária de 72 horas, eu acho muito, pra uma disciplina teórica, e não sei se é mais viável fazer empreendedorismo no projeto integrador, porque hoje eles trabalham com o que, teoricamente, seria o TCC e não funciona. 
Quem orientou sabe que na disciplina de gastronomia não funcionou [...]

A professora mencionou, ainda, a necessidade de rever a bibliografia e avaliar a experiência com o componente curricular e o curso, que foi ofertado pela primeira vez:

[...] a bibliografia é basicamente só o Dornelas. Eu não sei, como é a primeira vez que o curso foi ofertado, acho que tem vários reflexos de uma primeira vez de um curso sendo ofertado [...]

Outro elemento destacado pela professora foi a falta de estímulo à participação em eventos externos:

[...] tem o Sebrae que faz um monte de evento em Florianópolis, por exemplo, a Semana de Empreendedorismo, que coincide com o semestre e nem se fala desses eventos que existem sobre empreendedorismo. Não se aproveita muita coisa; poderia ser feito, talvez, um trabalho mais integrado com essas associações daqui. Eu até consegui aproximação com a ACIF, mas foram umas duas parcerias com a ACIF pra conseguir trazer o que existe em Florianópolis [...]"

Sobre quais iniciativas realizadas pelo IFSC são importantes para a aprendizagem de empreendedorismo, se há atividade realizada pelo IFSC que contribua, a professora relatou:

Eu acho que ano passado, aumentou a questão do empreendedorismo no IFSC, pelo menos ficou mais visual com o Desafio IFSC de novas ideias empreendedoras. Tivemos alguns alunos que participaram [...]

[...] mas não teve adesão por parte dos alunos do campus, o porquê não teve adesão talvez tivesse que se investigar, talvez tivesse que ter dado espaço dentro da disciplina de empreendedorismo pra participarem do desafio ou juntarem as disciplinas. Eu acho que ficou uma coisa que... eu fiquei com uma equipe que foi indo, foi indo, mas eu acho que foi porque eu ficava incomodando os alunos, porque as atividades deles para fazerem em casa, eles não queriam fazer [...] 
Outras atividades, não diretamente relacionadas com a instituição, também foram destacadas pela professora como importantes para estimular o empreendedorismo, ainda que não tenham relação direta com a temática. Segundo a professora:

[...] tiveram e de vez em quando têm eventos, tem aquele fórum de turismo Brasil-Espanha de inovação, e tem ali no campus. Percebi que a gente consegue no Encatho, tem um incentivo do curso de hotelaria para levar os alunos nesses eventos que eu acho que não são iniciativas diretas de empreendedorismo, mas que acabam fomentando o empreendedorismo. E a semana nacional de ciência e tecnologia também tem algumas ações, mas acho que pode aumentar [...]

Sobre as iniciativas que são importantes, a professora destacou que o Desafio IFSC foi importante para dar início às atividades, mas que precisa ser avaliado para ser aprimorado e realmente funcionar:

\begin{abstract}
Eu acho que o desafio abriu os olhos no sentido: "o IFSC quer fazer coisas de empreendedorismo e inovação", parece que vai, tanto que a parceria foi com o SEBRAE, o negócio certo Sebrae, que já é um programa que é consolidado no Brasil. Então, acho que esse desafio foi um desafio muito bom, mas, como todo projeto piloto, tem que ser aprimorado, tem que entrevistar quem participou para saber o que aprimorar. Daqui a pouco já está sendo lançado o segundo desafio IFSC sem entender o feedback do primeiro.
\end{abstract}

Sobre a relevância das iniciativas, a professora destaca que não é uma questão de não serem relevantes, mas, talvez, de serem melhor pensadas e melhor estruturadas, uma vez que há muitos alunos na informalidade, por exemplo, e que poderiam cursar o componente curricular de empreendedorismo nos cursos técnicos, não somente na graduação:

Tem iniciativas importantes, mas se for falar o que falta no IFSC, curso técnico, não se fala em empreendedorismo em curso técnico, inserir uma ação, ou um projeto. A gente tem muitos alunos na particularidade do nosso campus que são microempreendedores individuais e estão informais, não são $\mathrm{MEl}$, não têm o simples nacional, têm uma pequena empresa que nem tá registrada. No superior, eu até, às vezes, ficava questionando, qual era a importância de dar empreendedorismo 
no superior $e$ se não seria mais importante dar empreendedorismo num curso técnico, pela particularidade do nosso campus, tanto que, nas disciplinas que eu dei no curso técnico, todas elas tiveram uma aula de empreendedorismo, mesmo não estando nos PPCs. É uma coisa que quem tava se formando no curso técnico reclamava muito. 0 empreendedorismo aborda todas as disciplinas, passei material, ajudei alguns alunos a formar preço, a vender os produtos deles, só que talvez falte [...] formalizar [...]

Questionada sobre quais iniciativas do IFSC são importantes para incentivar a abertura de empresas ou criação de novos produtos na área do curso, a professora apresentou várias sugestões, que poderiam envolver os alunos, reforçando que eles possuem um perfil empreendedor, mas falta formalizar isso.

Segundo ela, a empresa júnior e o restaurante universitário poderiam ser boas opções para os alunos empreenderem, funcionando como escolas de empreendedorismo, que teriam a prática como elemento central:

[...] ter alguma coisa dos alunos, porque o nosso campus talvez de empreendedorismo seja o que mais tem alunos que empreendem [...], gastronomia principalmente, todo mundo empreende. Empreender é alguém vender um bolo, vender 0 doce, participar dessas feiras gastronômicas, que estão tendo um bum aqui em Florianópolis no momento, mas eu não vejo que eles saem preparados para abrir um negócio.

Outro aspecto destacado foi 0 fato de o componente curricular de empreendedorismo ser ministrado na última fase do curso e que não é integrado, ficando, assim, "solto" em relação aos outros componentes curriculares. Afora isso, a professora destacou aspectos da formalização, os quais ficam sem maiores explicações por falta de carga horária e/ou componente curricular próprio para isso:

[...] não tem nem tempo na disciplina pra explicar os tipos de formalização que existem, o que é uma empresa de grande porte, de pequeno porte, o que é o simples nacional, microempreendedor; essa noção de legislação, a noção tributária, quanto que custa ter um funcionário, quais são os encargos sociais [...]. 
Outro ponto destacado pela professora foi quanto à gestão. Segundo ela, a instituição não conseguiu ainda abordar o empreendedorismo do ponto de vista da melhoria da gestão:

[...] Eles não conseguiram olhar, chegar numa produção e ver, o que tem que melhorar de gestão. Assim como na hotelaria, eu acho que... tanto que muita gente não vai entregar os relatórios. Tu cobrar esse olhar de gestão, eu acho que falta de todo professor, em toda disciplina, pegar uma parte, o trabalho final fosse analisar a gestão, a parte de criticidade na gestão, e não tem, eu até acho que eu, em controladoria, também não dei, porque eu não tinha experiência nenhuma em sala de aula, não senti muito bem o curso, acho que foi o ponto falho da formação deles $[\ldots]$.

Diante do exposto pela professora na entrevista, pode-se afirmar que ainda há carência de práticas de empreendedorismo para que os alunos se aproximem da realidade e não fiquem somente em sala de aula, com as teorias. Ademais, os recursos disponibilizados para as atividades práticas são escassos, o que influencia a atividades apenas de sala de aula. Pode-se perceber que houve um esforço, de maneira isolada, por parte da professora de aproximar teoria e prática, embora 0 projeto não previsse tal intervenção.

Nesse sentido, a instituição poderia oportunizar, de forma complementar, assim como os alunos poderiam ter a iniciativa mediante orientação dos professores, por exemplo, de criar uma empresa júnior, que permitisse vivenciar situações práticas, com baixo custo, considerando a realidade de uma instituição pública, em detrimento de outras propostas como hotel-escola e restaurante pedagógico. 


\section{CAPÍTULO 5 - PRODUTO TÉCNICO}

Cabe à instituição de ensino criar ambiente favorável ao empreendedorismo, incluindo espaços de discussão e reflexão, nos quais seja possível o desenvolvimento de competências empreendedoras (SOUZA et al., 2005).

Assim, diante dos resultados da pesquisa, torna-se evidente a necessidade de proporcionar experiências empreendedoras aos alunos, sobretudo no sentido de estimular a identificação de oportunidades e criação de propostas de novos produtos ou serviços, na área de formação nos CST de Hotelaria e Gastronomia, podendo, inicialmente, atuar em nível local, mas com potencialidade para ser estendido aos demais cursos do campus, bem como aos demais campi.

Faz-se, portanto, necessário pensar em estratégias para proporcionar capacitação e incentivar a criação de projetos de empreendedorismo, visando a melhoria de processos já existentes, ou a criação de novos negócios, ensejando a potencialização da inserção do discente no mundo do trabalho, sob a perspectiva da protagonização.

\subsection{Laboratório Virtual de Empreendedorismo iLABEM: Um espaço virtual para capacitação e fomento de iniciativas empreendedoras}

Os artefatos tecnológicos que invadem as residências e aproximam os estudantes de conteúdos audiovisuais, cada vez mais interativos, tendem a levar os profissionais da Educação a uma nova concepção sobre recursos e estratégias a serem explorados para a construção do conhecimento. Dentre esses novos recursos tecnológicos, os mundos virtuais destacam-se por proporcionarem experiências de imersão fortemente realísticas (AMARAL, AVILA e TAROUCO, 2012).

Altos custos de implementação e uma grande demanda de usuários para um restrito espaço físico são alguns, dentre os tantos argumentos válidos para fundamentar a importância de se complementar as atividades laboratoriais escolares a partir de mundos virtuais (TORRES, 2007). 
Considerando as diferentes questões que inviabilizam a implantação de um laboratório físico no campus, quais sejam, indisponibilidade de espaço físico, restrições orçamentárias dada a atual conjuntura, dificuldade de mobilidade em uma cidade do porte de Florianópolis, e incompatibilidade de agenda do discente trabalhador para se fazer presente em horários do contraturno escolar, torna-se imprescindível estruturar estratégias que fomentem a participação em atividades, de modo a permitir a participação discente em local mais conveniente, como trabalho, casa, dentre outros.

Segundo Queiroz (1998), um laboratório virtual permite que usuários localizados distantes de um laboratório educacional ou de pesquisa utilizem remotamente os recursos do mesmo, como se os usuários estivessem presentes fisicamente no laboratório. O autor coloca, ainda, que tais laboratórios na Internet introduzem os "estudantes virtuais" às experiências sem os altos custos, as restrições de tempo e limitações de espaço, impostas por um laboratório real (QUEIROZ, 1998).

Já Harasim (1989) realça os atributos de interação, para caracterizar a educação online como um domínio com perspectivas inteiramente novas, baseada no aprendizado colaborativo que emerge de um diálogo ativo e da exposição de ideias dos participantes do grupo. Para Henri (2002), a interatividade é uma das características mais importantes da comunicação e é um dos fatores determinantes da aprendizagem, pois modifica sua natureza e sua qualidade.

A proposta de criação do Laboratório Virtual de Empreendedorismo (iLABEM) vem ao encontro da necessidade de oferecer oportunidades de capacitação, interação e fomento à identificação de oportunidades empreendedoras dos alunos, por meio da utilização de ferramentas virtuais.

A implantação do projeto está prevista para o início de 2017, em razão de tempo hábil de alocação da carga horária docente, e elaboração da plataforma virtual. Este projeto contará com um docente coordenador e docentes participantes que tenham afinidade com o tema, tanto por interesse ou aderência da área de formação.

As ferramentas virtuais utilizadas para realizar a interação com os discentes serão, preferencialmente, na base de softwares livres, como o Moodle ${ }^{7}$, diferenciando a ferramenta tradicional com interface amigável. A liberação de acesso será via login

\footnotetext{
7 MOODLE é o acrônimo de "Modular Object-Oriented Dynamic Learning Environment", um software livre, de apoio à aprendizagem, executado num ambiente virtual (ver ambiente virtual de aprendizagem).
} 
e senha, disponibilizados aos inscritos, bastando o discente ter acesso a um microcomputador com acesso à internet.

Embora as atividades do iLABEM sejam pautadas em ferramentas virtuais, os professores e técnicos administrativos envolvidos poderão utilizar uma sala de aula do campus ou do CERFEAD ${ }^{8}$ (Centro de Referência em EaD) para promover reuniões de planejamento das atividades, conforme a necessidade. A elaboração de aulas ou de atividades de interação será realizada no CERFEAD, já que este centro conta com a estrutura de mídias vinculadas à internet e estúdios, criados para realizar atividades desta natureza.

Esta proposta objetiva viabilizar capacitações, interações e atividades virtuais em Empreendedorismo, por meio de ferramentas vinculadas à internet. Moran (1998) destaca que a Internet ajuda a desenvolver a intuição, a flexibilidade mental, a adaptação a ritmos diferentes. A intuição, porque as informações são descobertas por acerto e erro, por conexões "escondidas". As conexões não são lineares, vão "linkando-se" por hipertextos, textos interconectados, mas ocultos, com inúmeras possibilidades diferentes de navegação.

O iLABEM poderá, assim, ajudar a resolver a lacuna de capacitação em Empreendedorismo, estimulando o surgimento de novos negócios.

\subsection{Justificativa}

A escolha do projeto de laboratório virtual iLABEM se dá pelos seguintes aspectos: custo zero à manutenção de sala e presença de pessoas; possibilidade de construir sobre um ambiente virtual de baixo custo; espaços virtuais de interação; acessível aos discentes com pouco tempo disponível; espaço virtual de capacitação e de fomento de iniciativas empreendedoras; aumento da visibilidade institucional; intervenção na realidade profissional por meio da inovação.

\footnotetext{
8 O Centro de Referência e Formação em EaD é uma diretoria vinculada à Pró-reitoria de Ensino, que atua na consolidação e implementação da política de formação do IFSC. Sua finalidade é qualificar os servidores do IFSC para o exercício de suas atividades, conforme as atividades previstas na lei de criação dos IFs; cumprir com a ampliação e consolidação da oferta formativa dos campus do IFSC por meio da $\mathrm{EaD}$, dentre outros.
} 


\subsection{Objetivos}

\subsubsection{Objetivo Geral}

Estimular os estudantes vinculados aos Cursos Superiores do IFSC, campus Florianópolis-Continente, a desenvolverem projetos de empreendedorismo, visando melhorar processos existentes nas áreas de formação ou desenvolvimento de novos produtos, em consonância com as demandas da comunidade.

\subsubsection{Objetivos Específicos}

1) Aprofundar conhecimentos na área de empreendedorismo, por meio de ações de capacitação virtuais;

2) Utilizar ferramentas virtuais que permitam o acesso às capacitações pelos discentes;

3) Desenvolver o potencial criativo dos discentes por meio das competências empreendedoras;

4) Estimular o protagonismo e a identificação de oportunidades;

5) Permitir a interação dos alunos com outros atores envolvidos no ecossistema ${ }^{9}$ de empreendedorismo.

\footnotetext{
${ }^{9}$ Ecossistema de Empreendedorismo: é, atualmente, considerado como um espaço regional que inclui um conjunto diversificado de intervenientes institucionais e individuais, fomentando o espírito empresarial, a inovação e o empreendedorismo (CARVALHO; VIANA; MANTOVANI, 2016).
} 


\subsection{Metodologia}

As metodologias de interação serão selecionadas a partir das proposições dos professores participantes deste projeto. Contudo, o Projeto do iLABEM compreende, resumidamente, as seguintes etapas:

1) Apresentação da proposta à Direção de Ensino do campus e ao diretor do CERFEAD;

2) Apresentação ao corpo docente do campus Florianópolis - Continente e identificação de pessoas para fazerem parte do projeto;

3) Seleção das ferramentas virtuais complementares de base livre para interação com os discentes;

4) Estruturação da página e plataforma virtual do iLABEM;

5) Capacitação dos professores participantes para uso das ferramentas e elaboração do plano de trabalho das atividades para o ano de 2017;

6) Lançamento de campanha interna para divulgar aos discentes;

7) Lançamento de edital para participação discente;

8) Início das atividades;

9) Certificação dos estudantes.

\subsection{Conteúdos que serão ministrados}

Considerando que o objetivo do iLABEM é oferecer a formação empreendedora, buscando capacitar os discentes a identificar oportunidades na área de formação, estimulando, desta forma, as iniciativas empreendedoras, e visando melhoria de processos ou abertura de novos negócios, o laboratório deverá capacitar, a partir da experimentação e da prática. Ou seja, a proposta é que os alunos trabalhem nos seus projetos à medida que são capacitados.

Nesse sentido, as temáticas principais para a formação empreendedora do iLABEM é sugerida com base nos achados desta pesquisa, principalmente considerando-se os apontamentos realizados pelos entrevistados. Compreenderão, assim, sem excluir outras, as seguintes temáticas: criatividade; identificação de 
oportunidades; análise de cenário; modelo de negócios; contratos de trabalho; inovação; trabalho em equipe; qualidade no atendimento; e formalização: aspectos legais, impostos, finanças, plano de negócios, microcrédito.

\subsection{Resultados Esperados}

Espera-se, ao final de cada ano, por meio das capacitações oferecidas no sentido de desenvolver competências empreendedoras, que os discentes tenham projetos estruturados, e que esses projetos sejam apresentados por meio de seminários a potenciais investidores. 


\section{CONSIDERAÇÕES FINAIS}

Os cursos superiores de tecnologia do IFSC, campus Florianópolis-Continente, aqui analisados, pertencem ao Eixo Tecnológico: Turismo, Hospitalidade e Lazer, e tais ofertas possuem especificidades, tanto relativas à natureza da atuação quanto aos desafios que compreendem formar sujeitos para trabalharem nessa área.

Neste tocante, ao observar os projetos de cada curso, nota-se que todo o seu conteúdo não referencia quaisquer teorias pedagógicas à abordagem das competências, de forma que não apresenta clareza de qual conceito de competência o PPC trata. As atitudes são trazidas como atitudes gerais do curso, o qual também não deixa evidenciada qual base teórica fundamenta tal distinção.

Essa ausência de norteamento teórico claro nos documentos institucionais dificulta a capacitação dos professores para o ensino por competências. Fragiliza a construção do PPC e, em efeito cascata, o plano de ensino.

Outro ponto a observar é o enfoque dado ao realizar a justificativa do curso. A perspectiva apresentada se concentra na condição de atender os interesses dos empresários. Poucos foram os dados trazidos no sentido de colocar as necessidades de formação do trabalhador ou de alguma inserção empírica, que tenha sido referenciada para justificar as ofertas do ponto de vista das demandas sociais, a necessidade da oferta dos cursos.

A palavra competência aparece algumas vezes no texto de ambos os PPCs, de forma isolada, com inserção diversa do conceito atribuído à tríade, conhecimentos, habilidades e atitudes. No texto, o sentido da palavra aparece de forma restrita, com mero sentido de atribuição, limitando a amplitude do conceito.

No item que menciona a metodologia, não há opções claras e diversificadas de como abordar o ensino por competências. Faz referência superficial à necessidade da interdisciplinaridade, no entanto não faz comentários à natureza dessa formação, para que fique clara a distinção da formação de bacharéis, passando a impressão de que a construção do projeto foi um procedimento mecânico, protocolar, moldada pela herança de construção de outras instituições de ensino. Logo, carece de olhar atento à identidade da EPT.

Ademais, as ementas trazem bases tecnológicas, ao invés de conhecimentos e habilidades a serem desenvolvidas. As atitudes não foram mencionadas em cada 
componente curricular, e, sim, aparecem de maneira genérica no projeto do curso. Logo, considerando a análise documental efetivadas dos PPCs, dos planos de ensino utilizados no componente curricular de Empreendedorismo, e as entrevistas realizadas, é possível afirmar que o componente curricular de empreendedorismo estimula, parcialmente, os alunos a empreenderem.

Empreendedorismo é componente curricular dos cursos, mas o instituto ainda não consegue fazer com que seja uma constante, pois o trabalho ainda é realizado de forma superficial, com práticas elaboradas somente pela docente, dependendo de sua iniciativa, vontade e disponibilidade. Ademais, a docente atual tem vínculo de professora substituta, o que não garante a continuidade do trabalho realizado atualmente, depois do encerramento de seu vínculo com a instituição, bem como a elaboração de projetos e práticas a longo prazo.

Por outro lado, o empreendedorismo, analisado do ponto de vista do posicionamento que o IFSC assume frente ao tema, é marginalizado na prática institucional, não havendo clareza conceitual por parte dos docentes, técnicos e núcleos pedagógicos, ficando assim, refém das múltiplas correntes teóricas, em sua maioria equivocadas, que ora trazem viés meramente empresarial, ou no outro extremo a negação total desta prática por entender que está atrelada meramente ao fortalecimento do sistema capitalista, como se o ato de negar a prática do empreendedorismo deixasse os alunos menos expostos às fragilidades do capital.

O Empreendedorismo não pode ser visto como apêndice ou tema secundário, pois figura em posição de destaque na lei de criação dos Institutos quando abordado como uma das atividades finalísticas da instituição, no entanto quando nos deparamos com a prática, é visto de um lado amparado por teorias preconceituosas frente ao tema, desconsiderando que o empreendedorismo pode ser uma alternativa para a inclusão e usado como estratégia para tornar os alunos protagonistas no combate às questões limitantes do mercado e de outro lado, a visão superficial, limitada às questões empresariais, desprovidas do caráter agregador e transformador da sociedade em que vivemos.

Transpor o discurso teórico e propor a construção do conceito do empreendedorismo que queremos é o primeiro passo para avançar nas barreiras invisíveis que impedem de avançarmos sob a perspectiva teórica e prática. Nota-se que o empreendedorismo no IFSC é frágil quando atribuído a um docente que está em caráter temporário e com trabalho desarticulado de outras iniciativas. Sendo 
considerado apenas como mero ato de constituir uma empresa, vender algo, estabelecer comércio de algum produto ou serviço que gere renda. Outro elemento a ser destacado refere-se ao empreendedorismo ser abordado somente em uma disciplina, o que não garante a qualidade da aprendizagem dos alunos, além da pequena carga horária que tem caráter disciplinar. Assim, de acordo com os apontamentos da pesquisa, observa-se a necessidade de equilibrar a carga horária teórica e prática, uma vez que a concepção do currículo no IFSC requer que este seja atualizado, contextualizado e significativo e, ainda, voltado para a realidade.

Docente e discentes que participaram da pesquisa afirmaram que 0 componente curricular é concebido do ponto de vista teórico, inclusive o dimensionamento da carga horária e a falta de espaço para atividades práticas.

Diante disso, cabe, novamente, cabe mencionar que a formação do empreendedor passa pela aquisição de conhecimento e habilidades, experiências, capacidade criativa e inovadora (SOUZA, 2001). Assim, o perfil empreendedor é a capacidade da pessoa criar, conduzir e implementar o processo criativo, de elaborar novos planos de vida, de trabalho, de estudo, de negócio sendo com isso responsável pelo seu próprio desenvolvimento, pelo de sua organização e da comunidade (SOUZA, 2001).

Tendo em vista essas questões, e considerando a análise documental realizada dos PPCs, dos planos de ensino utilizados no componente curricular de Empreendedorismo, e as entrevistas realizadas, é possível afirmar que o componente curricular de empreendedorismo estimula, parcialmente, os alunos a empreenderem. Logo, é necessário, para que os resultados sejam obtidos a curto prazo, desenvolver um projeto paralelo no campus, que estimule os estudantes a participar, que seja inclusivo, com baixo custo de implantação e operacionalização, utilizando, de preferência, a estrutura e os recursos disponíveis. Desse modo, torna-se uma alternativa viável para dar sequência nesse estudo.

A proposta de criação do Laboratório Virtual de Empreendedorismo (iLABEM) vem ao encontro da necessidade de oferecer oportunidades de capacitação, interação e fomento à identificação de oportunidades empreendedoras dos alunos, por meio da utilização de ferramentas virtuais. Para tanto podem ser utilizados a estrutura existente e os recursos disponíveis no IFSC, por meio do CERFEAD (Centro de Referência em Educação a Distância), que possui estrutura física e corpo docente com formação na área afim, que pode incorporar esta proposta, otimizando os 
recursos disponíveis.

O processo de adaptação do projeto do curso para a formação por competências, com destaque para a observância de estímulos ao desenvolvimento das competências empreendedoras, e, paralelamente, trazendo a ideia de que o IFSC invista em projetos alternativos que insiram 0 discente no universo do empreendedorismo, se configurarão em grandes avanços para que, mesmo o discente atuando como funcionário de uma empresa, ele saiba o valor das suas ações, e, com isso, se sinta preparado para protagonizar a sua atuação em qualquer contexto que trabalhe, seja abrindo um novo negócio ou não. 


\section{REFERÊNCIAS BIBLIOGRÁFICAS}

ALVES-MAZZOTTI, Alda Judith. Usos e abusos dos estudos de caso. Cad. Pesquisa [online]. 2006, vol.36, n.129, pp.637-651.

AMARAL, Erico; AVILA, Barbara G.; TAROUCO, Liane M. R. Aspectos teóricos e práticos da implantação de um laboratório virtual no OpenSim. In: SIMPÓSIO BRASILEIRO DE INFORMÁTICA NA EDUCAÇÃO, 23., 2012, Rio de Janeiro. Anais... Rio de Janeiro: Sbie, 2012. v. 1, p. 1 - 5. Disponível em: <http://www.lbd.dcc.ufmg.br/colecoes/sbie/2012/0096.pdf>. Acesso em: 23 mar. 2016.

AVENI, Alessandro. Empreendedorismo contemporâneo: Teorias e Tipologias. São Paulo: Atlas, 2014.

BRASIL. Lei no 11.892, de 29 de Dezembro de 2008. Institui a Rede Federal de Educação Profissional, Científica e Tecnológica, cria os Institutos Federais de Educação, Ciência e Tecnologia, e dá outras providências. Disponível em: http://www.planalto.gov.br/ccivil 03/ ato2007-2010/2008/lei//11892.htm Acesso em: 15 jan. 2015.

CARVALHO, L. M. C.; VIANA, A. B. N.; MANTOVANI, D. M. N.. O papel da FAPESP no ecossistema empreendedor do Estado de São Paulo. In: Racef, [s.I.], v. 7, n. 1, p.84-101, 11 mar. 2016. FUNDACE. Disponível em: http://dx.doi.org/10.13059/racef.v7i1.168. Acesso em 15 de março de 2016.

CRESWELL, J. W. Projeto de pesquisa. Porto Alegre: Artmed, 2010.

FILION, L. J. Empreendedorismo: empreendedores e proprietários-gerentes de pequenos negócios. Revista de Administração, São Paulo v.34, n.2, p.05-28, abril/junho, 1999.

GIMENEZ, F. A. P.; FERREIRA, J. M.; RAMOS, S. C. Configuração Empreendedora ou Configurações Empreendedoras? Indo um pouco além de Mintzberg. In: Anais XXXII Encontro ANPAD, FGV DIREITO RIO, 2008. Disponível em: http://www.anpad.org.br/admin/pdf/ESO-C2571.pdf Acesso em: 25 de março de 2016.

HARASIM, L. On-line education: a new domain. In: MASON, R; KAYE, A. (Ed.). Mindweave: communication, computers and distance instruction. Oxford: Pergamon, 1989. 
INSTITUTO FEDERAL DE SANTA CATARINA. Plano de Desenvolvimento Institucional 2015-2019, 2014.

KOTLER, P.; KELLER, K. L. Administração de Marketing. 14. ed. São Paulo: Pearson Prentice Hall, 2012.

MARCONI, M. de A.; LAKATOS, E. M. Conclusão. In: MARCONI, Marina de Andrade; LAKATOS, Eva Maria. Fundamentos de metodologia científica. $7^{a}$ São Paulo: Atlas, 2008.

MICHAELIS. Dicionário Prático: Língua Portuguesa - Nova Ortografia. Melhoramentos, 2011.

MORAN, J. M. Mudanças na comunicação social. São Paulo: Paulinas, 1998.

QUEIROZ, L. R. de. Um laboratório virtual de robótica e visão computacional. Dissertação (Mestrado) - Curso de Ciência da Computação, Instituto de Computação, Universidade Estadual de Campinas, Campinas, 1998. $61 \mathrm{f}$.

SOUZA, E. C. L. de. A disseminação da cultura empreendedora e a mudança na relação universidade - empresa. In: Souza, E. C. L.de (org.). Empreendedorismo: competência essencial para pequenas e médias empresas. Brasília: ANPROTEC, 2001.

SOUZA, E. C. L. de; CASTRO-LUCAS, C. de S.; ASSIS, S. de A. G.; ZERBINI, T. Métodos, técnicas e recursos didáticos de ensino do empreendedorismo em IES brasileiras. In: SOUZA, E. C. L. de; GUIMARÃES, T. de A. G. (Org.).

Empreendedorismo além do plano de negócio. 1ed. São Paulo: Atlas, 2005, v. 1, p. 200-216.

SOUZA, E. C. L. de; CASTIONI, R. (Org.). Institutos federais: os desafios da institucionalização. Brasília: Unb, 2012. 221 p.

TORRES, P. L. Laboratório online de aprendizagem: uma experiência de aprendizagem colaborativa por meio do ambiente virtual de aprendizagem EUREK@KIDS. In: Caderno Cedes, Campinas, v. 73, n. 27, p.335-352, set./2007. Disponível em:

$<$ https://www.researchgate.net/profile/Patricia_Torres7/publication/262445475_Onlin e_learning_laboratory_a_collaborative_learning_experiment_with_the_use_of_the_E 
urekKids_virtual_learning_environment/links/544a7f730cf2bcc9b1d2f4de.pdf>. Acesso em: 13 abr. 2016.

ZABALZA, M. A. O ensino Universitário: seu cenário e seus protagonistas. Tradução Ernani Rosa. Porto Alegre: Artmed, 2004. 


\section{Questionário docente}

1) Sexo/idade/tempo de docência/substituto ou efetivo

2) Área de formação (tecn/graduação/esp/mestrado/doutorado)

3) Experiência na área de Empreendedorismo (por exemplo: atuação empresarial, consultoria, empresa própria, etc).

4) Experiência na docência de Empreendedorismo (número de anos/disciplinas).

5) Possui formação especifica em Empreendedorismo? Onde? Como foi?

6) Qual metodologia utilizas para ministrar o componente curricular de empreendedorismo? Por quê? Como você organiza as aulas/momentos com os alunos?

7) Possui formação pedagógica em ensino por competências? Conte um pouco sobre essa formação.

8) Acredita que o componente curricular de empreendedorismo (currículo, bibliografia, metodologia, carga horária, etc) presente no currículo dos CST do IFSC campus Florianópolis - Continente, é suficiente ou não é suficiente para motivar o discente a empreender? Justifique.

9) Quais iniciativas realizadas pelo IFSC são importantes para a aprendizagem de empreendedorismo ou não há atividade realizada pelo IFSC que contribua?

10) Se há iniciativas importantes: Qual a relevância dessas iniciativas?

11) Se não há iniciativas importantes: Porque não há relevância nessas iniciativas?

12) Quais iniciativas do IFSC são importantes para incentivar a abertura de empresas ou criação de novos produtos na área do curso? 


\title{
Questionário discente
}

\author{
1) Sexo \\ 2) Idade \\ 3) Trabalha atualmente? \\ 4) Em qual área? \\ 5) Há quanto tempo? \\ 6) Qual seu vínculo profissional? (MEI, Freelancer, CLT, sócio de empresa, outros) \\ 7) O seu trabalho atual é na área do curso? Explique. \\ 8) Você já teve alguma experiência com empreendedorismo? Qual? \\ 9) Na sua opinião, empreendedor "nasce pronto" ou se desenvolve ao longo da vida?
}

10) As oportunidades ou necessidades econômicas influenciam na atividade empreendedora? Justifique.

11) Qual a sua opinião sobre o componente curricular de empreendedorismo cursada no 5 o período? Por quê? (considere, por exemplo, conteúdo, metodologia, bibliografia, atividades, carga horária, etc).

12) Considera que houve alguma contribuição do componente curricular de Empreendedorismo na sua intenção de empreender ou não? Por quê?

13) Você se considera motivado a empreender após cursar o componente curricular de empreendedorismo?

14) Caso deseje empreender, em qual área se sente mais motivado? Por quê?

15.1) Se já empreende, conte um pouco da sua experiência.

15.2) Se não empreende, conte um pouco dos motivos para não ter empreendido.

16) Acredita que o componente curricular de empreendedorismo (currículo, bibliografia, metodologia, carga horária, etc), é suficiente ou não é suficiente para motivar o aluno a empreender? Justifique.

17) Quais iniciativas realizadas pelo IFSC são importantes para a aprendizagem de empreendedorismo ou não há atividade realizada pelo IFSC que contribua?

18) Você considera que há iniciativas no IFSC para a aprendizagem de empreendedorismo além das aulas? Qual a relevância dessas iniciativas?

19) Se você considera que não há iniciativas importantes no IFSC para a aprendizagem de empreendedorismo, explique.

20) Se não, quais considera importantes que o IFSC adote para incentivar o empreendedorismo?

21) Há iniciativas no IFSC que são importantes para incentivar a abertura de empresas ou criação de novos produtos na área do curso? Quais? 
1 DADOS DA IES.

1.1 MantenA

1.1 Mantenedora

1.2 Mantida - Campus Proponente 4

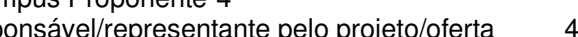

SECRETARIA DE EDUCACÃO PROFISSIONAL E TECNOLÓGICA

NSTIUTO FEDERAL INSTITU CATARINA.

PROJETO PEDAGÓGICO DE CURSO - PPC

CAMPUS FLORIANÓPOLIS-CONTINENTE

\section{CURSO SUPERIOR DE TECNOLOGIA EM HOTELARIA}

Eixo Tecnológico: TURISMO, HOSPITALIDADE E LAZER

\section{Florianópolis, agosto de 2014}

4.4 Perfil Profissional do Egresso 19

5.2 Articulação Ensino Pesquisa e Extensão 24

5.7 Componentes curriculares 30
1.4 Contextualização da IES 5

2 DADOS DO CURSO 10

2.1 Nome do curso 10

2.2 Modalidade

2.3 Eixo/Area 10

2.4 Carga horária e Periodicidade 10

2.5 Integralização 10

2.6 Requisitos Legais $\quad 10$

2.7 Dados para preenchimento do diploma

4 DADOS DA OFERTA 11

3.1 Quadro Resumo 11

4. ASPECTOS GERAIS DO PROJETO PEDAGÓGICO 12

4.1 Justificativa do curso 12

4.2 Justificativa da oferta do curso 16

4.3 Objetivos do curso 19

4.5 Competências profissionais 20

4.6 Áreas de atuação

4.7 Possíveis postos de trabalho 21

4.8 Ingresso no curso 21

5 ESTRUTURA CURRICULAR DO CURSO

5.1 Organização didático pedagógica

5.4 Representação Gráfica do Perfil de Formação 25

5.5 Certificações Intermediárias 27

.6 Matriz Curricular 28

5.8 Atividades complementares 63

5.9 Avaliação do Processo Ensino Aprendizagem 63

5.10 Trabalho de Curso 64

5.11 Projeto integrador 65

5.12 Estágios curricular e Acompanhamento do estágio 65

5.13 Prática supervisionada nos serviços ou na industria, e acompanhamento das práticas

supervisionadas 68

5.14 Atendimento ao discente

5.15 Atividades de Tutoria (para cursos EAD)

68

5.16 Critérios de aproveitamento de conhecimentos e experiências anteriores 68

5.17 Avaliação do projeto do curso 69

5.18 Incentivo a pesquisa, a extensão e a produção cientifica e tecnológica $\quad 70$

5.19 Integração (rede pública/licenciatura, rede regional e SUS/saúde, empresas)

6. CORPO DOCENTE E TUTORIAL

6.1 Coordenador do Curso 71

6.2 Corpo Docente 71

6.3 Corpo Administrativo 76

6.4 Núcleo Docente Estruturante

6.5 Colegiado do Curso 79

7 INFRAESTRUTURA FÍSICA

7.1 Instalações gerais e equipamentos 
7.4 Polos de apoio presencial, se for o caso, ou estrutura multicampi (para cursos EAD) 7.5 Sala de tutoria (para cursos EAD)

EAD) 82

7.7 Biblioteca 82

7.7.1 Instalações/espaço físico $\quad 82$

7.7.2 Equipamentos 8

7.7.3 Mobilia 82

7.7.4 Acervo bibliográfico 82

7.7.5 Acesso dos alunos e equipamentos informática

7.8 Instalações e laboratórios de uso geral e especializados

7.8.1 Laboratórios Especializados

7.8.1.1 Laboratório de Hotelaria

8.REFERÊNCIAS
81

\section{DADOS DA IES \\ 1.1 Mantenedora}

Nome da Mantenedora: Instituto Federal de Educação, Ciência e Tecnologia de Santa Catarina

Endereço: Rua 14 de julho

Bairro: Coqueiros

CEP: $88075-010$

Telefone(s): (48) 38779000

CNPJ: 11.402.887/0001-60

Número: 150

Estado: SC

Ato Legal: Lei 11.892 de 29 de dezembro de 2008

Endereço WEB: www.ifsc.edu.br

Reitor(a): Maria Clara Kaschny Schneider

1.2 Mantida - Campus Florianópolis - Continente

Nome da Mantida: Instituto Federal de Educação, Ciência e Tecnologia de Santa Catarina Endereço: Rua 14 de julho

Bairro: Coqueiros

Cidade: Florianópolis

Número: 150

Telefone(s): (48) 38778430

CNPJ: $11.402 .887 / 0001-60$

Ato Legal: Portaria $n^{\circ} 1490$ de 24 de agosto de 2006.

Endereço WEB: www.ifsc.edu.br

Diretor Geral(a): Nelda Plentz de Oliveira

\subsection{Nome do responsável/representante pelo projeto/oferta}

\begin{tabular}{|c|c|c|}
\hline Comissão & Relação com o Curso & Email \\
\hline Fabíola Martins dos Santos & \begin{tabular}{|l} 
Docente do Curso \\
Coordenadora \\
Superior do \\
Hotelaria
\end{tabular} & fabiola@ifsc.edu.br \\
\hline Carlos Alberto da Silva Mello & Docente do Curso & carlos.mello@ifsc.edu.br \\
\hline Vinícius de Luca Filho & Docente do Curso & vinidelucca@ifsc.edu.br \\
\hline Pedro Raymundo & Docente do Curso & Pedro.raymundo@ifsc.edu.br \\
\hline Tiago Savi Mondo & Docente do Curso & Tiago.mondo@ifsc.edu.br \\
\hline
\end{tabular}

\subsection{Contextualização da IES}

O Instituto Federal de Educação, Ciência e Tecnologia de Santa Catarina (IFSC) foi criado pela Lei no 11.892 de 29/12/2008. É uma Autarquia Federal, vinculada ao Ministério da Educação por meio da Secretaria da Educação Profissional e Tecnológica - SETEC, com CNPJ 11.402.887/0001-60, sediada em imóvel próprio, na Rua 14 de julho, 150, Enseada dos Marinheiros, Bairro Coqueiros, Florianópolis-SC. De acordo com a legislação de criação, a finalidade do IF-SC é formar e qualificar profissionais no âmbito da educação profissional técnica e tecnológica nos níveis fundamental, médio e superior, bem como ofertar cursos de licenciatura e de formação pedagógica, cursos de bacharelado e de pós-graduação lato e stricto sensu. Para isso, a instituição atua em diferentes níveis e modalidades de ensino, oferecendo cursos voltados à educação de jovens e adultos, de formação inicial e continuada, técnicos, de graduação e de pós- 
graduação. Assim, o IF-SC busca cumprir a sua missão de: "desenvolver e difundir conhecimento científico e tecnológico, formando indivíduos capacitados para o exercício da cidadania e da como visão de futuro consolidar-se como centro de excelência na educaça profissional tecnológica no Estado de Santa Cataina. Isso já é uma realidade, pois nos quatro úlimos anos (dados de 2012) o IF-SC alcançou, com base jo IGC (lndice Geral de Cursos), meltrapa Centro Federal Universitário Federal do país. Por no ultrapassa os limites geográficos e oferece cursos técnicos, de graduação e pós-graduação em 33 polos de ensino em SC, RS, PR e sP. Nos úlimos ancos, de o IF-SC estabeleceu parcerias com instituições de ensino estrangeiras para intercâmbio de alunos e servidores.

Segundo o anuário de dados referentes à 2013, o IFSC teria cerca de 28.765 alunos distribuídos em 32 campi pelo estado de Santa Catarina, incluindo o Centro de Referência em Formação $E A D$, além da Reitoria, atuando na oferta de educação tecnológica em todos os níveis e com formação de educadores.

Em 1909, quando a sociedade passava da era do trabalho artesanal para o industrial, nascia em Florianópolis a Escola de Aprendizes Artífices, com o objetivo de proporcionar formação profissional aos filhos de classes socioeconômicas menos favorecidas. Ao longo dos anos, instituição passa por sucessivas mudanças estruturais: Liceu Industrial de Florianópolis (1937); Escola Industrial de Florianopolis (1942); Escola Industrial Federal de Santa Catarina (1962); Escola Técnica Federal de Santa Catarina (1968). Com a transformação em CEFET (2002), suas atividades foram ampliadas e diversificadas, com a implantação de cursos de graduação tecnológica, de pós-graduação (especialização) e a realizacão de pesquisa e de extensão. Em 29/12/2008, de pós-graduação (especialização) e a realização de pesquisa e de extensão. Em pela transformação em Instituto Federal de Educação Ciencia e Tecnologia de Santa Catarina. Ampliam-se as acões e compromisso com a inclusão social investem-se mais recursos financeiros, ampla autonomia financeira e didático-pedagógica se fortalece e assegura-se uma identidade para a Educação Profissional e Tecnológica. A instituição oferece educação profissional e tecnológica gratuita em todas as regiōes de SC, contribuindo, assim, para o seu desenvolvimento nível deno nivel de educaçăo superior: a) cursos superiores de tecnologia visando à formação de profissionais para os diferentes setores da economia; b) cursos de licenciatura e programas especiais de formação pedagógica, com vistas à formação de professores para a educação básica, sobretudo nas áreas de ciências e física e química , e para a educação profissional".

O Campus Florianópolis-Continente (CFC) surge em 2006, ainda como Unidade Continente do então CEFET-SC. Além de ser a primeira escola federalizada no contexto de expansão da Rede Federal de educação profissional (federalização da Escola Catarinense de Gastronomia) o CFC também o primeiro Campus exclusivamente voltado para o eixo tecnológico Turismo, Hospitalidade e Lazer (THL). Nesse sentido, destaca-se o pioneirismo da Instituição que, ao instalar essa unidade de ensino com sua oferta formativa baseada no referido eixo tecnológico, contribui para o fortalecimento da área, ainda em construção na Rede de Educação Profissional Tecnológica.

O processo de expansão possibilitou à organização, novos desafios e perspectivas e fez com que o pensamento gestor se ampliasse.

As áreas de atuação dos IFSC estão delimitadas em eixos tecnológicos. Este Projeto Pedagógico de Curso se insere no eixo Turismo, Hospitalidade e Lazer, voltado para as áreas de Turismo, de Curso se insere no eixo Turia, Eventos e Gastronomia.

A oferta de cursos gratuitos e de qualidade no eixo tecnológico Turismo, Hospitalidade e Lazer é um marco, pela localização deste campus - inserido em uma cidade turística, com expressiva oferta de emprego nos diversos setores turísticos. Sua importância não reside somente na necessidade de ofertar serviços turísticos de qualidade no âmbito do estado catarinense, mas também na missão de inserir o trabalhador melhor qualificado no mundo do trabalho.

A formação profissional no CFC está organizada em quatro itinerários formativos : gastronomia eventos, hotelaria e turismo. Em cada itinerário, é disponibilizada ao público-alvo a continuidade de formação profissional associada à elevacãa de escolaridade. Até hoje o Campus tem se dedicado, principalmente, à oferta de cursos Técnicos e de Formação Inicial e Continuada (FIC), consolidando a base do itinerário formativo.

Considerado hoje como ícone na formação profissional em Turismo, Hospitalidade e Lazer, o CFC tem se constituído em uma referência para o planejamento e implementação de novos cursos e laboratórios desse eixo na Rede Federal, contribuindo assim para o fortalecimento da atividade econômica do turismo no Brasil e para a melhoria na formação de profissionais para a área.

Seguindo a perspectiva de inclusão da classe trabalhadora, o CFC implementa ações que beneficiam o ingresso e a permanência do público alvo, como a aplicação de questionário socioeconômico para o ingresso nos cursos de qualificação, o acompanhamento pedagógico dos alunos e a assistência estudantil. Iniciativas como o Programa Nacional de Integração da Educação Profissional com a Educação Básica na Modalidade de Educação de Jovens e Adultos (PROEJA), realizado em parceria com municípios e com o Estado Catarinense; o Programa de Certificação Profissional e Formação Inicial e Continuada (CERTIFIC) para os perfis de auxiliar de cozinha, garçom, padeiro, camareira e guia de turismo; e a oferta de cursos em outros município - via extensão - buscando atingir um público carente de oportunidades de formação profissional, são também exemplos.

O Campus tem sido também palco para a construção de parcerias com atores da área de turismo e de eventos como o Conselho Municipal de Turismo, o Grupo Gestor dos 65 Destinos Indutores e de eventos como o Conselho Municipal de Turismo, o Grupo Gestor dos 65 Destinos Indutores de Turismo, a VIF); Gastronomica de Coqueiros, a Associaçao Comercial e lndusthal de Florianis (UATAPI), Construida nos moldes da economia solidária, assim como para o intercâmbio com França, atraves do estag mo de professores e alo nos dos ilinerários de hotelaria, turismo dos dois países, e da recepção de alunos de intercâmbio canadenses.

Atualmente a escola conta com um efetivo que se aproxima de 100 servidores, sendo 35 técnicoadministrativos e 55 professores que atendem a um universo de mais de 1.000 alunos matriculados em cursos presenciais e a distância. São ofertados os cursos técnicos subsequentes de Hospedagem, Gastronomia, Panificação e Confeitaria, Guia de Turismo e Eventos, além de uma diversidade de cursos de Formação Inicial e Continuada (FIC), entre os quais: Condutor Cultural, Condutor Ambiental, Cerimonialista e Mestre de Cerimônia, Recepcionista de Eventos, Organização de Eventos Sociais, Operações Básicas em Cozinha, Operações Básicas em Panificação e Confeitaria; Serviços de Vinhos, Coquetelaria, Gestão de Empreendimentos em A B, Espanhol para o Turismo, Inglês para o Turismo e LIBRAS.

O itinerário da área de Hotelaria surgiu juntamente com o Campus, sendo o curso Técnico em Hospedagem o primeiro curso ofertado pelo CFC, em março de 2007. O itinerário Gastronomia iniciou em 2007, com densa oferta de cursos de FIC e de técnicos. Quanto aos cursos técnicos, Campus ofertou ao longo da sua história diversas turmas dos cursos de Cozinha, de Serviços de Restaurante e Bar e de Panificação (transformado em 2009, com sucesso, em Panificação Confeitaria).

Ao longo de quase seis anos de sua intensa história o CFC consolida-se como referência no eixo THL, tendo percorrido uma trajetória que lhe permitiu gradativamente obter novas conquistas. A oferta inicial de cursos FIC e técnicos, sequencialmente, possibilitaram o fortalecimento do 
Campus de forma a atingir a maturidade necessária para a oferta de cursos de graduação, em um processo gradual de verticalização, como é o caso do curso Superior de Tecnologia em Hotelaria proposto no presente projeto.

A instalação do Campus Florianópolis-Continente, como Instituto Federal de Santa Catarina, é um marco para o eixo tecnológico Turismo, Hospitalidade e Lazer. Primeiro, pelo contexto geográfico marco para o eixo tecnológico Turismo, Hospitalidade e Lazer. Primeiro, pelo contexto geográfico no qual se encontra - instalada em uma cidade turistica, com expressiva oferta, tanto no setor hoteliro, como nos setores de eventos e gastronômico. Esse Campus, portanto, tem como objetivos iniciais a qualificação e/ou formação técnica dos trabalhadores que já exercem funçõe relacionadas aos setores de allmentos e bebidas, hospedagem, eventos e turismo, que exercem seu trabalho sem formação, ou com formação parcial.

O turismo hoje é um dos principais atores na economia mundial, situando-se entre os três maiores geradores de riqueza, só perdendo para a indústria de armamentos e de petróleo. (WTTC, 2009). Dentro da ampla gama de elementos do setor turístico, os empreendimentos de hospedagem (hotéis, pousadas, resorts, etc.) têm papel fundamental para o desenvolvimento do setor. Barreto (2007) menciona que a hotelaria nasceu como um elemento complementar do turismo. A partir do século XII as hospedarias já eram vistas nas estradas europeias e aos poucos os países como França e Inglaterra implantavam leis para regulamentar a atividade.

Corroborando com o autor, Campos e Gonçalves (1998) defendem que os meios de hospedagem são fundamentais na viabilização da atividade turística e a falta deles pode fazer com que uma região com grande potencial turístico não se desenvolva. Os meios de hospedagem agem no mercado do turismo recebendo clientes/hóspedes e a eles oferecem além do serviço de hospedagem serviços complementares como o de lazer, alimentação, passeios, estacionamento, internet, entre outros (MONDO, 2010). No que diz respeito à região de Florianópolis, de acordo com Santos (2005), depois dos anos de 1970 percerimento vertiginoso no 1019 de 547 em 1960 para 1019 em 1980. Esta cuna ascenden capital onze novos hotels e o número de unidades habitacionais sobe para 1474 (1990), para 2126 2005). Ainda de acordo com o hospedagem com mais de 20 mil leitos.

A partir deste contexto, o Campus Florianópolis-Continente do Instituto Federal de Santa Catarina apresenta o Projeto Pedagógico do curso Superior de Tecnologia em Hotelaria, com o intuito de atender à demanda potencial de meios de hospedagem da região para capacitação, formação e possível elevação da qualidade dos serviços hoteleiros prestados através de um curso superio torna-se diferencial no Sul do país, onde cursos públicos superiores em hotelaria existem somente no Paraná e Rio Grande do Sul. Dessa forma, acredita-se que o IFSC, através da oferta do Curso de Tecnologia em Hotelaria, continua cumprindo sua finalidade social de formar e qualificar profissionais no âmbito da educação profissional e tecnológica, contemplando mais um nível/modalidade de ensino, auxiliando no desenvolvimento dos diversos setores da economia, em estreita articulação com os setores produtivos e a sociedade, especialmente de abrangência loca regional, oferecendo mecanismos para a educação continuada.

\section{DADOS DO CURSO}

\subsection{Nome do curso}

Curso Superior de Tecnologia em Hotelaria.

\subsection{Modalidade}

Presencial.

\subsection{Eixo/Área}

Turismo, Hospitalidade e Lazer, conforme Parecer CNE/CEB 03/2012.

\subsection{Carga horária e Periodicidad}

\begin{tabular}{|c|c|}
\hline Carga Horária Total & Periodicidade \\
\hline 2.272 horas & Anual \\
\hline
\end{tabular}

\subsection{Integralização}

\begin{tabular}{|c|c|}
\hline $\begin{array}{c}\text { Prazo MíNIMO para conclusão } \\
\text { do curso }\end{array}$ & $\begin{array}{c}\text { Prazo MÁXIMO para conclusão } \\
\text { do curso }\end{array}$ \\
\hline 6 (seis) semestres & $100 \%$ \\
& 12 (doze) semestres \\
\hline
\end{tabular}

2.6 Requisitos Legais

A legislação educacional pertinente ao curso é a Lei 9.394 de 20 de dezembro de 1996 que estabelece as Diretrizes e Bases da Educação Nacional e nos termos do art. 71 , $\S 1^{\circ}{ }^{\circ}$ e $2^{\circ}$, do Decreto 5.773 , de 2006 que dispõe sobre a adequação da denominação dos cursos superiores de tecnologia ao Catálogo Nacional de Cursos Superiores de Tecnologia. 
O curso foi elaborado à luz do Catálogo Nacional de Cursos Superiores de Tecnologia do Ministério da Educação (MEC) que estabelece as Diretrizes Curriculares Nacionais para a Educação Profissional de Nível Tecnológico.

\subsection{Dados para preenchimento do diploma}

\begin{tabular}{|c|c|c|c|}
\hline Nome do Curso & Titulação & $\begin{array}{c}\text { Legislação } \\
\text { Específica }\end{array}$ & $\begin{array}{c}\text { Carga Horária do } \\
\text { Curso }\end{array}$ \\
\hline $\begin{array}{c}\text { Curso Superior de } \\
\text { Tecnologia em } \\
\text { Hotelaria }\end{array}$ & $\begin{array}{c}\text { Tecnólogo em } \\
\text { Hotelaria }\end{array}$ & Não se aplica & 2.272 horas \\
\hline
\end{tabular}

\section{DADOS DA OFERTA}

1 Quadro Resumo

\begin{tabular}{|c|c|c|c|}
\hline $\begin{array}{c}\text { Periodicidade da } \\
\text { Oferta }\end{array}$ & Turnos & $\begin{array}{c}\mathbf{N}^{\circ} \text { de Vagas } \\
\text { discente por turma }\end{array}$ & $\begin{array}{c}\text { Total de Vagas } \\
\text { Anuais }\end{array}$ \\
\hline Anual & Matutino & 40 (quarenta) & 40 (quarenta) \\
\hline
\end{tabular}

\section{ASPECTOS GERAIS DO PROJETO PEDAGÓGICO}

\subsection{Justificativa do curso}

De acordo com o WTTC (2010), o Brasil aparece em 13이 lugar no ranking de países turísticos, que leva em conta vários indicadores do setor como, importância do turismo para o PIB, geração de empregos, divisas geradas por turistas internacionais e investimentos públicos e privados.

Os dados do WTTC reforçam a imagem internacional que o país tem hoje. O mundo o vê como um dos mais promissores, pelo bom desempenho da economia, pelos investimentos que acontecem para a Copa e as Olimpíadas, e pelo grande potencial de desenvolvimento que tem o turismo, tanto doméstico quanto internacional (MTur, 2010)

O Brasil ainda está entre os 10 primeiros países que devem produzir o maior volume em termos absolutos de PIB do turismo em 2012 (10ํlugar); na geração de empregos (diretos e indiretos) do

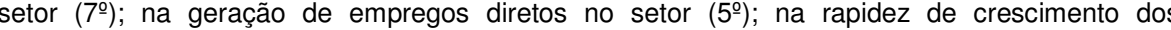
investimentos no setor (5) (WTTC, 2010; MTUR, 2010).

Os dados da EMBRATUR (2009) reforçam tal fato. A variação de crescimento de vôos internacionais nos aeroportos Brasileiros foi de $7,89 \%$ entre os anos de 2006 e 2007 , demonstrando o crescimento do setor. (EMBRATUR, 2008).

Os principais continentes emissores, segundo EMBRATUR (2008) são da América do Sul Europa com quase 2 milhões de turistas por ano cada, seguidos da América do Norte (cerca de 850 mil chegadas) e África ( 80 mil chegadas). O Oriente Médio e a Ásia chamam atenção pelo 850 mil chegadas) e Africa (

O Ministério do Turismo Brasileiro, através do Instituto Brasileiro de Turismo (EMBRATUR) realizam anualmente estudos relativos à demanda internacional no país. No tocante aos meios de hospedagem, a pesquisa de 2005-2007 mostrou que 60,7\% dos turistas utilizaram-se de meios de hospedagem para o serviço de alojamento em suas viagens. Destaca como principais emissores Unidos, Portugal, Itália, Chile, Alemanha, França, Uruguai e Espanha (EMBRATUR, 2009).

Em Santa Catarina, de acordo com a SANTUR (2009) o movimento de turistas nos meses de alta temporada (janeiro e fevereiro) foi de aproximadamente 4,5 milhões em 2009, tendo um crescimento de 8\% com relação à 2007. Em 2011, a ocupação média em alta temporada ficou em $85 \%$.

A ABIH-SC realizou uma pesquisa em 2008 para inventariar os meios de hospedagem do Estado. Concluiu que existem aproximadamente 2.750 meios de hospedagem, somando um total de 110.000 Unidades Habitacionais (UH's) e 275.000 leitos. De acordo com a Associação, $40 \%$ dos meios de hospedagem são pousadas e pequenos hotéis, $54 \%$ hotéis de médio porte e $6 \%$ hotéis de grande porte, que possuem mais de $80 \mathrm{UH}^{\prime} \mathrm{S}(\mathrm{ABIH}, 2008)$.

setor hoteleiro gera cerca de 220 mil empregos em Santa Catarina, sendo 55 mil empregos diretos e 165 mil indiretos (ABIH, 2008).

Cabe destacar que MTUR (Brasil, 2011) registra a ascensão de Florianópolis no ranking dos destinos turísticos brasileiros, em relação à demanda internacional que visitou o Brasil por motivo 
de lazer. Em 2004, Florianópolis ocupava a $5^{\text {a }}$ posição no ranking, atrás do Rio de Janeiro, Foz do Iguaçu, São Paulo e Salvador. Já no ano de 2005, Florianópolis passou a ocupar a $4^{a}$ posição, a frente de Salvador e, em 2006. Florianópolis apareceu na $3^{a}$ posição, a frente também de São Paulo, posição que município vem mantendo decd eño com participacão de mercado de $153 \%$ ficando atrás visitantes de Florianópolis uilizam-se dos meios de ho ASIL, 2011).

A partir do exposto, verifica-se que o destino turístico "Florianópolis" figura entre os principais do país. Tal fato remete à necessidade de prestação de serviços de qualidade, bem como de estrutura qualificada para receber turistas nacionais e internacionais. Por isso, a realização de um curso de tecnologia em hotelaria se justifica pelo tato de promover a qualificação profissional de trabalhadores no âmbito não somente da operação dos serviços hoteleiros, mas na sua concepção, análise e implementação.

De acordo com o Ministério do Turismo, em um cenário de crescimento acelerado e de ganhos de competitividade, o mercado interno poderá alcançar, no ano de 2014, o patamar dos 500 milhões de postos de trabalho nas atividades características do turismo, com 35,4 mil estabelecimentos hoteleiros, 78 milhões de desembarques domésticos e sete milhões de turistas estrangeiros, com impacto de US\$ 9 bilhões em divisas internacionais (BRASIL, 2011).

Sobre o crescimento do mercado de turismo no Brasil e em Florianópolis, percebe-se que o setor vem trabalhando para a melhoria nos próximos anos. Declarações, na mídia especializada, de expectativas extremamente favoráveis por parte de analistas, investidores e profissionais do turismo, anúncios de novos investimentos e o correspondente aumento das consultas de empresas do ramo hoteleiro aO BNDES anunciam excelentes perspectivas e ratificam a trajetória de crescimento esperada. (IBGE, 2011).

Além disso, a disponibilidade de unidades habitacionais nas redes hoteleiras das cidades turísticas do Brasil tem atraído a atenção do setor. O Ministério do Turismo acenou recentemente com a quatro anos, 0 que sugere aumento das po quatro anos, o que sugere auns pivados de RS 8 bihöe necessidade de qualificação profissional (BRASIL, 2011).

Assim, verifica-se que a qualificação profissional está diretamente ligada com o avanço da economia. Tal fato é corroborado pela análise econômica brasileira dos últimos 10 anos, onde ocorreu crescimento da economia e também aumento da oferta de qualificação profissional.

O Estado de Santa Catarina é composto por 295 municípios sendo que estes estão agrupados em 36 Secretarias de Desenvolvimento Regional - SDR, em dez regiões turísticas, 20 associações de municípios (microrregiões) e seis mesorregiões. Cada região turística faz parte do programa de Regionalização do Ministério do Turismo. Tal divisão ocorreu a partir de aspectos territoriais, culturais e mercadológicos relacionados com a segmentação turística. O quadro abaixo apresenta a composição das regiões turísticas de acordo com as microrregiões.

\begin{tabular}{|l|l|}
\hline Regiões Turísticas & Microrregiões \\
\hline 1. Caminho dos Príncipes & Joinville e São Bento do Sul \\
\hline 2. Vale do Contestado: & Concórdia, Joaçaba, Canoinhas e Curitibanos \\
\hline 3.Grande Oeste: & Chapecó e Xanxerê \\
\hline
\end{tabular}

\begin{tabular}{|l|l|}
\hline 4. Costa Verde e Mar: & Itajaí \\
\hline 5. Vale Europeu: & Blumenau, Rio do Sul, Tijucas e Ituporanga. \\
\hline 6. Grande Florianópolis: & Florianópolis e Tabuleiro \\
\hline 7. Encantos do Sul & Criciúma e Tubarão \\
\hline 8. Caminho dos Cânions: & Araranguá \\
\hline 9. Serra Catarinense: & Lages \\
\hline 10. Caminhos da Fronteira & Dionísio Cerqueira, São Miguel do Oeste \\
\hline
\end{tabular}

Fonte: Elaborado pelos autores do projeto, em 2014

O Estado de Santa Catarina recebe milhões de turistas a cada ano e sua demanda real tem crescido cada vez mais, conforme demonstra no quadro baixo:

\begin{tabular}{|c|c|c|c|c|c|}
\hline Origem & 2005 & 2006 & 2007 & 2008 & \%crescimento de 2005 a 2008 \\
\hline Nacionais & 2.570 .651 & 2.937 .561 & 3.539 .198 & 3.794 .388 & $47,60 \%$ \\
\hline Estrangeiros & 202.211 & 211.782 & 468.954 & 509.035 & $151,73 \%$ \\
\hline & 2.772 .862 & 3.149 .343 & 4.008 .152 & 4.303 .423 & $55,20 \%$ \\
\hline
\end{tabular}

Fonte: EMBRATUR (2010). Elaborado pelos autores do projeto, em 2012.

No ano 2008, o Estado de Santa Catarina conta com 2.402 empresas cadastradas no setor de hospedagem que são responsáveis pela geração 14.680 empregos (SEBRAE-SC, 2010), conforme a demonstra no quadro abaixo:

\begin{tabular}{|c|c|c|c|c|c|c|c|c|}
\hline \multirow[b]{2}{*}{ Regiões } & \multicolumn{2}{|l|}{ Hotelaria } & \multicolumn{2}{|c|}{ Alimentação } & \multicolumn{2}{|c|}{$\begin{array}{|ll|}\begin{array}{l}\text { Outros } \\
\text { turísticos }\end{array} & \text { serviços } \\
\end{array}$} & \multicolumn{2}{|l|}{ Total } \\
\hline & Empresa & Emprego & Empresa & Emprego & Empresa & Emprego & Empresa & Emprego \\
\hline $\begin{array}{l}\text { Região } \\
\text { Norte }\end{array}$ & 323 & 1517 & 4821 & 8675 & 313 & 492 & 5.457 & 10.684 \\
\hline $\begin{array}{l}\text { Região do } \\
\text { Vale do Itajá }\end{array}$ & 727 & 4971 & 6428 & 13485 & 578 & 890 & 7.733 & 19.346 \\
\hline $\begin{array}{l}\text { Região de } \\
\text { Florianópolis }\end{array}$ & 610 & 4296 & 4225 & 14869 & 785 & 1964 & 5.620 & 21.129 \\
\hline Região Sul & 283 & 1574 & 2326 & 3909 & 214 & 328 & 2.823 & 5.811 \\
\hline $\begin{array}{l}\text { Região } \\
\text { Serrana }\end{array}$ & 125 & 549 & 1165 & 1804 & 61 & 60 & 1.351 & 2.413 \\
\hline $\begin{array}{l}\text { Região } \\
\text { Oeste }\end{array}$ & 334 & 1773 & 5119 & 4323 & 263 & 216 & 5.716 & 6.312 \\
\hline $\begin{array}{l}\text { Santa } \\
\text { Catarina }\end{array}$ & 2402 & 14680 & 24084 & 47065 & 2214 & 3950 & 28.700 & 65.695 \\
\hline
\end{tabular}

Fonte: Resultados elaborados pelo SEBRAE-SC a partir de dados do MTE e RAIS de 2008.

Constata-se que as regiões do Vale do Itajaí e de Florianópolis concentram-se o número maior de estabelecimentos de hoteleiros e as duas regiões geram 9.267 empregos formais, o que representa cerca de $60 \%$ dos empregos gerados em todo o Estado de Santa Catarina. 
O turismo se caracteriza como importante atividade de integração sociocultural, promovendo o intercambio de diferentes culturas e o estreitamento das relações entre as sociedades, com relevantes contribuicões para a ge relevantes contribuiçoes para a geração de renda e emprego. Através do turismo, o pais ou região divulga suas paisagens, tradçoes, gastron contribuindo para a preservaçăo dos patrimonios arquitetônicos e ambientais, bem como para difusão de sua imagem, em níveis internacionais e intranacional. O turismo
círculo virtuoso e contribui para o desenvolvimento sustentável (IBGE, 2011).

Em Santa Catarina, destaca-se ainda a presença de Grupos Nacionais e Internacionais do Setor de Turismo tais como:, STB, Cl, ACCOR, Bristol, Deville, Slaviero, Hertz, Localiza, Movida, Pizza Hut, McDonald's, Bob's, Habib's, entre outros, que fortalecem a imagem do Estado como importante destinação turística em âmbito nacional e internacional.

O crescimento esperado da demanda turística, como o que está acontecendo na capita catarinense, segundo o IBGE (2011) exige uma estrutura compatível com essa demanda, em especial, no que concerne à melhoria dos serviços turisticos, que abrangem os transportes, locadoras de automóveis, agências de viagens e serviços de hospedagem e alimentação.

É possível afirmar ainda, que os serviços de hospedagem estão no último elo da cadeia de serviços turísticos e configuram-se como um dos mais importantes, pois representam a base de permanência temporária do turista, que, de uma forma geral, busca encontrar a extensão de sua residência, ou seja serviços que reproduzam o mesmo padrão de conforto de sua residência habitual (IBGE 2011). Neste ponto verifica-se a importância da qualificação profissional em gestão e operação de serviços hoteleiros, perfil profissional do egresso do curso aqui discutido.

\subsection{Justificativa da oferta do curso}

O Instituto Federal de Santa Catarina possui papel importante dentro do contexto turístico da cidade de Florianópolis. O Campus Florianópolis-Continente é ícone na oferta de cursos do eixo cidade de Florianópolis. O Campus Florianópolis-Contipente é icone na oferta de cursos do eixo de Turiso, Hospitalidade e Lazer. Dentro do inario formalivo do Campus, o curso de Tecnologla em Hotelaria surge na perspectiva de contribuir para o desenvolvimento dos meios de hospedagé da regláo. Alẽ disso, O IFSC possui participaçáo no Grupo Gestor da cidade, onde o turismo é disculido e açoes estratégicas propostas. Cabe apontar que as regióes do Vale do Itajaí e da Grande Florianópolis são as que concentram um número maior de empresas hoteleiras no Estado de Santa Catarina, especialmente na capital catarinense.

De acordo com a pesquisa de competitividade turística realizada pela parceria entre Ministério do Turismo e FGV, Florianópolis obteve um crescimento de 13,5\% no quesito "Serviços equipamentos turísticos" de 2008 a 2010. Tal fato levanta a discussão de que ainda é necessária a qualificação da mão de obra em serviços e equipamentos turísticos em Florianópolis. O índice de competitividade de 75,9 (máximo de 100), alcançado em 2010 pela cidade é considerado dentro da média dos 65 destinos indutores do turismo no país, desta forma, passível de melhoria (BRASIL, 2011).

Um exemplo do fato da necessidade de qualificação de trabalhadores pode ser a avaliação que a Federação Internacional de Handebol fez da hotelaria da cidade para o Mundial de Handebo Feminino que seria realizado em 2011. De acordo com a IHF (2011), a hotelaria da cidade necessitava de melhoria nos serviços prestados, estrutura de unidades habitacionais o de atendimento a turistas internacionais. O evento foi realizado em São Paulo por Florianópolis não atender às demandas da Instituição.

Através deste exemplo percebe-se que Florianópolis possui estrutura e trabalhadores no turismo, mas que de certa forma falta qualificação da mão de obra e incentivo à melhoria desta estrutura questões que o curso de tecnologia em hotelaria poderá fomentar. Tal fato se intensifica quando, segundo o Dieese (2008) a maior parcela da força de trabalho formalizada da atividade de Turismo e Hospitalidade de Florianópolis possui o ensino médio completo. Isso revela que aumento dos anos de estudo da população do país nas últimas décadas tem se manifestado no ramo (DIEESE, 2008) e a justificativa de oferta de um curso superior na área.

Em pesquisa realizada por Professores do Campus Florianópolis-Continente do IFSC constatouse também que há a necessidade de qualificação profissional para as Governantas que atuam em se também que há a necessidade de qualificação profissional para as Governantas que atuam em
empreendimentos hoteleiros em Florianópolis. Das pesquisadas, $45 \%$ possuem ensino médio completo e diante das exigências operacionais e administrativas do cargo, torna-se importante o completo e diante das exigências operacionais e administrativas do cargo, torna-se importante 0 investimento em formação especifica na área. Alem disso, $61 \%$ das governantas apontaram que não realizam o planejamento orçamentário, o processo de compras dos produtos, materiais equipamentos do setor e o gerenciamento dos custos operacionais; $30 \%$ das investigadas colocam não possuir autonomia para decidir sobre a necessidade da realização de admissão demissão de seus subordinados. Pode-se afirmar que as atribuições administrativas do cargo de Governanta não são comuns nos hotéis pesquisados. Esse fato deve-se, provavelmente, pela falta de conhecimento das profissionais sobre a gestão financeira, de processos e de pessoas, competências estas compreendidas na proposta pedagógica do curso aqui referido.

O Plano de Desenvolvimento Sustentável de Florianópolis (2011) aborda ações estratégicas que devem ser operacionalizadas nos próximos 5 anos para melhoria do Sistema de Turismo da cidade. Dentre elas, identifica-se duas que justificam a abertura e realização do curso de tecnologia em hotelaria: a) fomento e promoção da capacitação profissional para inserção econômica no setor turístico e b) estímulo a política de valorização profissional, inclusive salarial, para trabalhadores de turismo e hospitalidade.

Este plano, ainda identifica alguns pontos fundamentais no que diz respeito a educação profissional como indutora do desenvolvimento turístico. De acordo com o documento, elaborado a partir de pesquisas realizadas em 2011, a capacitação e qualificaccão profissional e empresaria continuada são fatores fundamentais para o desenvolvimento do turismo em Florianópolis e para tanto as seguintes ações estratégicas serão adotadas:

a) A municipalidade, por recursos próprios ou de terceiros, promoverá a oferta permanente adequada de programas de capacitação de mão de obra para as atividades turísticas;

b) Estimular a criação de cursos e treinamentos específicos para colaboradores de empresas turísticas;

c) Estimular as instituições de ensino no processo de capacitação técnica da mão de obra local, envolvida direta e indiretamente na atividade turística

d) Desenvolver programas de educação ambiental e iniciação ao turismo e suas potencialidades no ensino fundamental;

e) Fomentar a criação de grupos técnicos para orientação e capacitação dos prestadores de serviço das micro e pequenas empresas do setor;

f) Incentivar e fomentar o empreendedorismo no turismo através de oficinas, cursos e eventos; g) Estimular às empresas para a adoção de programas permanentes de educação continuada em serviços e melhoria da qualidade;

h) Criar mecanismos de valorização diferenciada às empresas do setor turístico detentoras de certificados reconhecidos de qualidade e classificação.

Um curso de Tecnologia em Hotelaria iria promover diversos destes pontos contemplados no Plano de Desenvolvimento Turístico da cidade.

A oferta do curso Superior de Tecnologia em Hotelaria pode se justificar pelo crescimento da oferta e demanda turística em Santa Catarina e a recorrente necessidade de qualificação profissional. Os cursos técnicos disponíveis estão qualificando profissionais para as operações profissional. Os cursos técnicos disponiveis estão qualificando profissionais para as operaçoes 
da oferta de meios de hospedagem de turismo, para que seja possível a qualificação de profissionais para atuarem não somente para operacionalização de serviços hoteleiros, mas também na gestão e concepção destes empreendimentos.

\subsection{Objetivos do curso}

\subsubsection{Objetivo Geral}

Formar gestores hoteleiros com competência e habilidades para administração operacional dos meios de hospedagem de turismo, com visão crítica e empreendedora, aptos para concepção gestão e supervisão operacional dos serviços hoteleiros, para a prestação de serviços de assessoria técnica e/ou consultoria e para pesquisa na hotelaria.

\subsubsection{Objetivos Específicos}

- Formar e atualizar com novas tecnologias de trabalho, gestores, supervisores e coordenadores hoteleiros para atuarem na gestão operacional dos meios de hospedagem de turismo;

- Desenvolver capacidades para função de gestor, supervisor e coordenador da administração econômica, financeira, comercial e operacional dos serviços hoteleiros:

- Desenvolver as características profissionais para empreender e analisar o mercado hoteleiro;

- Formar trabalhadores com atitudes proativas para o diagnostico e gerenciamento dos problemas e criação de soluções, voltados para os resultados econômicos, financeiros e problemas e criação de sol

- Orientar para o desenvolvimento da sua responsabilidade social e ambiental nos meios de hospedagem de turismo.

\subsection{Perfil Profissional do Egresso}

O perfil do egresso do Tecnólogo em Hoteleira do IFSC Campus Florianópolis-Continente está coerente com a justificativa e os objetivos do curso, além de atender as diretrizes curriculares dos cursos de tecnologia e às necessidades atuais do mercado.

Atendendo ao catálogo nacional de cursos superiores do MEC, o egresso estará apto para o planejamento e a operacionalização de espaços, equipes e atividades nos diversos departamentos de hotéis, resorts, flats, spas, estâncias e complexos turísticos são as atividades do tecnólogo em Hotelaria. Ele coordena desde serviços de limpeza, arrumação e ornamentação das unidades habitacionais, salão de refeições, áreas externas e internas, cozinha, até aspecto de gerenciamento, como contratação, orientação e supervisão de funcionários, organizacão da infraestrutura $e$ instalações do estabelecimento. Este profissional pode ainda auxiliar montagem de novos empreendimentos holeleiros, definindo planos de marketing e estabelecendo relações com empresários e autoridades locais.

\subsection{Competências profissionais}

- Identificar no sistema turístico e nas interelações com o mercado hoteleiro o contexto ambiental, social e econômico nas escalas local, regional, nacional e internacional;

- Realizar uma comunicação oral e escrita eficiente e eficaz, utilizando corretamente os termos técnicos e usuais do turismo e da hotelaria com base nos conceitos da hospitalidade e do bem receber;

- Dimensionar serviços, tarefas e pessoas de acordo com a categoria de serviços e tipo de estabelecimento hoteleiro
- Planejar e executar as operações técnicas de todos os setores de um meio de hospedagem de turismo, entre os quais, recepção, reservas, governança, alimentos e bebidas e eventos, respeitando as normas de segurança do trabalho e de higiene;

- Gerir, com responsabilidade social e ambiental, a operação hoteleira, criando rotinas, fluxos, processos e controles operacionais de todos os setores e departamentos de um hotel desde a sua concepção, planejamento, implantação, operacionalização, comercialização e avaliação.

- Aplicar os conceitos de empreendedorismo no contexto da operação e na concepção de um novo negócio ou serviço na hotelaria

- Desenvolver ferramentas administrativas de um meio de hospedagem, no que se refere à gestão: financeira, de pessoas, de materiais, estratégica, controladoria e de marketing com sustentabilidade respeitando os preceitos da ética profissional.

\subsection{Areas de atuação}

O egresso do curso Superior de Tecnologia em Hotelaria estará apto a atuar:

- Meios de Hospedagem de Turismo;

- Outras áreas de atuação são consideradas como: Cruzeiros Marítimos, Fluviais e Empresas Ferroviárias;

- Academia / Pesquisa - Instituições e Núcleos de Ensino e Pesquisa, público ou privados;

- Empresas de Assessoria e/ou Consultoria Técnica;

- Meios de Comunicação Especializados no segmento de Hotelaria e Alimentos e Bebidas.

\subsection{Possíveis postos de trabalho}

Gerência Operacional ou de Hospedagem; Governante de Hotel; Coordenação ou Supervisão de Andares; Gerência ou Chefia ou Coordenação de Recepção; Concierge; Guest Service; Gerência ou Coordenação ou Supervisão de Alimentos e Bebidas; Gerência ou Coordenação ou Supervisão Administrativa Financeira; Gerência ou Coordenação ou Supervisão Comercial; Coordenação ou Supervisão de Reservas; Promotor de Vendas; Executivo de Contas; Gerência ou Coordenação ou Supervisão de Recursos Humanos, entre outros.

\subsection{Ingressos no curso}

A forma de ingresso de alunos para o Curso Superior de Tecnologia em Hoteleira dar-se-á através de processo seletivo do tipo vestibular, atendendo ao Plano de Inclusão e aos editais do Departamento de Ingresso do IF-SC. O curso será ofertado para todos os candidatos que tenham concluído, no mínimo, o Ensino Médio.

A forma de ingresso dar-se-á anualmente através de exame vestibular ou ENEM, de acordo com os critérios utilizados pelo DEING-IFSC. As especificacões do concurso para ingresso no curso serão apresentadas nos editais e nos manuais do candidato. 
espaços físicos, a carga horária disponível do quadro docente e a infraestrutura, além dos critérios pedagógicos e da legislação pertinente. O curso Superior de Tecnologia em Hotelaria observará em regra definido pelo CONSUP, a quantidade de 40 (quarenta) alunos, podendo ser divididas em duas turmas de 20 (vinte) alunos para as aulas práticas em laboratório.

A formação do conhecimento passará pela integração da teoria e da prática em laboratório, além A formação do conhecimento passará pela integração da teoria e da prática em laboratório, além
do estágio supervisionado obrigatório em serviços de hotelaria, respeitando os horários do estágio supervisionado obrigatorio em serviços de hotela
planejados pelas instituições para melhor aprendizado do discente.

\section{ESTRUTURA CURRICULAR DO CURSO}

\subsection{Organização didático pedagógica}

O curso Superior de Tecnologia em Hoteleira está organizado por um conjunto de competências serem desenvolvidas em seis semestres de 360 horas cada e atenderá ao disposto no Regimento Didático-Pedagógico (RDP) que é o documento único de gestão do processo educacional que estabelece as normas referentes aos processos didáticos e pedagógicos desenvolvidos por todos os Campus do Instituto Federal de Educação, Ciência e Tecnologia de Santa Catarina (IFSC).

O regime de matrícula é por componente curricular (matrícula por disciplina), na qual um conjunto de componentes curriculares é escolhido pelo aluno a cada semestre letivo. Entende-se por componente curricular como disciplina e demais atividades acadêmicas (estágio e TCC) constantes na matriz curricular do curso.

A matrícula por componente curricular possibilita a aplicação de metodologias como a Educação Am Competência, onde um 位 do processo educativo.

O acadêmico que for aprovado em todos os componentes curriculares do semestre deverá matricular-se nas disciplinas da fase subsequente. Para o caso de reprovação em algum componente curricular/ disciplina, o estudante deverá privilegiar a matrícula na disciplina pendente (sempre que possível), assim como, nas demais disciplinas desde que não haja prérequisitos para o componente curricular pendente.

Sobre as disciplinas pendentes poderá o aluno se matricular, desde que se atendam as seguintes condições: i) disponibilidade de vagas da disciplina, ii) compatibilidade de horários entre as disciplinas pendentes, e os componentes curriculares da fase seguinte; iii) respeito aos prérequisitos para a disciplina desejada.

Para os casos de reprovação em alguma disciplina, considerando o espaço físico existente e a carga horária disponível do quadro docente, poderá se criar uma turma especial no contra turno do curso para conclusão de componentes curriculares pendentes, desde que o número de discentes interessados na matrícula for igual ou maior que cinco. Para os componentes curriculares que não desenvolvam habilidades práticas, caso o número de discentes tenha sido inferior a cinco, a critério da Coordenação do Curso, o aluno poderá cursar a disciplina na modalidade semipresencial. Nesta modalidade o aluno terá aulas presenciais e a distância por meio de estudos dirigidos direcionados por professor específico da área. O estudo dirigido é uma estratégia de ensino, onde o professor serve de orientador e facilitador da aprendizagem e o aluno com o seu acompanhamento direto faz a resolução as tarefas pré-determinadas.

curso Superior de Tecnologia em Hotelaria possui periodicidade semestral, mas com oferta de curso superior de Tén ing $00 \mathrm{~min}$ às 12 h00 min. A composição e a organização de turmas considerará a otimização dos
A parte prática dos componentes curriculares será ministrada nos laboratórios existentes no campus Florianópolis- Continente e no Laboratório de Hotelaria extra campus. O campus Florianópolis-Continente possui um contrato de locação localizado a 15 minutos do Campus Florianópolis-Continente, que possibilita a realização de aulas práticas no contexto de uma situação real da operação hoteleira. São disponibilizadas pelo hotel 10 Unidades Habitacionais, acesso aos setores de Recepção, Rouparia e Lavanderia e uma sala de eventos equipada com cadeiras e projetor multimídia, além de produtos e equipamentos para realização das práticas. Destaca-se que as aulas práticas, realizadas em meios de hospedagem em operação, proporcionam a realização de um trabalho integrado por meio do desenvolvimento de competências que visam atingir a qualificação necessária do sujeito para o seu exercício profissional. Os alunos conseguem relacionar os conhecimentos técnicos aprendidos em sala de aula com a realidade operacional vivenciada na empresa, permitindo catalisar o ensino e aprendizagem.

Para realização de visitas técnicas e estágios em estabelecimentos hoteleiros da região, entre os quais, cita-se: Intercity Premium Florianópolis; Ibis Florianópolis: Ibis São José; Baía Norte Palace Hotel; Hotel Castelmar; Slaviero Via Catarina; Mercure Centro; Kennedy Executive e entre outros.

O projeto de ampliação do Campus Florianópolis-Continente prevê a construção de um Laboratório de Hospedagem/Governança, que são espaços de sala equipados com uma Unidade Habitacional Modelo e uma Recepção Modelo. Sobre a infraestrutura dos laboratórios futuros estará descrita adiante neste projeto.

\subsection{Articulação Ensino Pesquisa e Extensão}

A articulação, no curso Superior de Tecnologia em Hotelaria se dará através de trabalhos inter multidisciplinares que possibilitem a integração das unidades curriculares do curso, que envolvam a participação do corpo docente, discente e comunidade externa. As atividades de extensão possibilitam desenvolver a integração entre a teoria e a prática por meio da organização e/ou participação em eventos que envolvam o curso e a comunidade externa ou ainda, pelo desenvolvimento de pesquisas de campo orientadas pelos docentes do curso.

curso prevê $10 \%$ da carga horária dos seus componentes curriculares poderão ser direcionadas para projetos e ou para ações de extensão com envolvimento de alunos, professores comunidade.

Para realizar a articulação ensino, pesquisa e extensão, o comportamento investigativo importante ser trabalhado com os alunos, tanto nas atividades realizadas em sala de aula, como fora dela. Nesse sentido, o curso prevê a participação em editais de pesquisa e/ou extensão promovidos internamente pela instituição ou por outras instituições; a participação em eventos técnicos e científicos do corpo docente juntamente com os alunos e ainda, o desenvolvimento de técnicos e científicos do corpo docente juntamente com os alunos e ainda, o desenvolvimento de
atividades de extensão, de caráter investigativo, por meio de Visitas Técnicas em empreendimentos hoteleiros, que possam diagnosticar e apontar a resolução de problemas. 
A partir da realização de atividades extensionistas orientadas pelo corpo docente os alunos terão a oportunidade de exercitarem os conhecimentos e as habilidades apreendidas no curso, assim como a possibilidade de vivenciarem as experiências singulares no decorrer do processo de formação, tornando-os mais aptos para o enfrentamento da vida profissional.

\subsection{Metodologia}

A Proposta Pedagógica para o desenvolvimento da metodologia educacional das competências por componentes curriculares deve prever não só a articulação entre as bases tecnológicas como por componentes curriculares deve prever não só a articulação entre as bases tecnológicas como comunicação e a complementaridade entre as fases do curso deverão ocorrer continuamente.

Nas disciplinas de Língua Inglesa Aplicada (1 e 2), as atividades poderão ser desenvolvidas com a participação de um docente da área técnica. Para tanto, uma carga-horária de 8 horas-aulas poderá ser destinada para este professor.

As formas como acontecerão estas comunicações dar-se-ão por meio de diversas técnicas de ensino, entre as quais, expositivo-dialogada, atividade de laboratório, trabalho individual, trabalhos em grupo, debate, estudo de caso, seminário, visitas técnicas e a campos de trabalho, palestras com gestores da área, leitura de artigos e similares com temas relevantes para formação em hotelaria. As reuniões pedagógicas regulares de construção, discussão e socialização dos planos de ensino também são formas de comunicação.

\subsection{Representação Gráfica do Perfil de Formação}

Apresenta-se na Figura a seguir a representação gráfica do curso Superior em Tecnologia em Hotelaria do IFSC, Campus Florianópolis Continente, demonstrando a sequência de passos necessários para que o estudante adquira o diploma em Tecnólogo em Hoteleira:

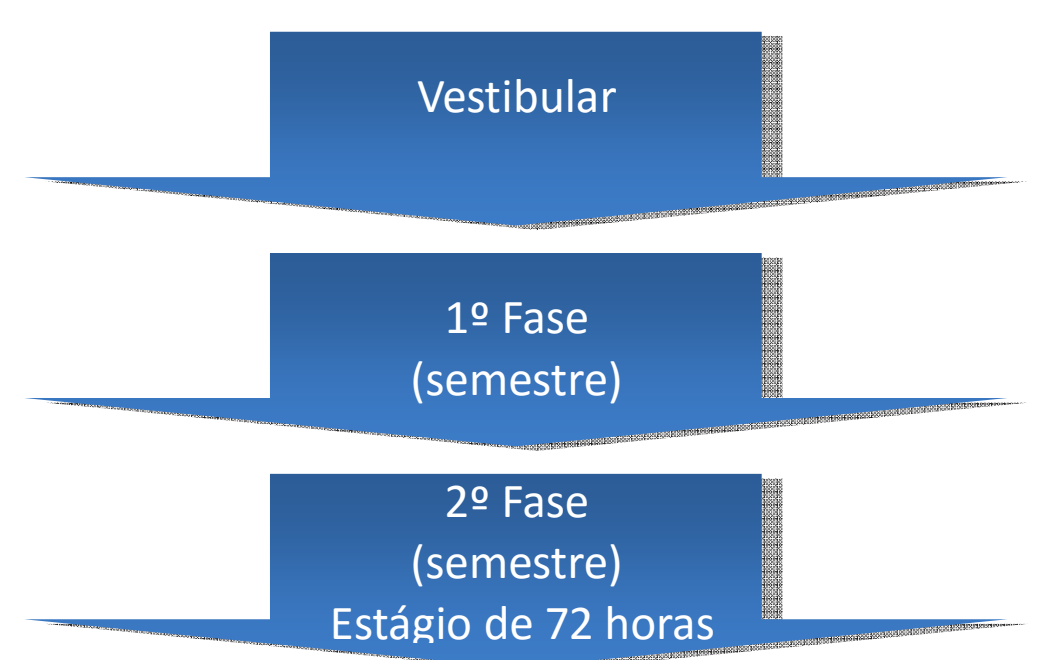

3ㅇ Fase (semestre)

Certificação: Qualificação

em Operação de Recepção,

Reservas e Governanca.

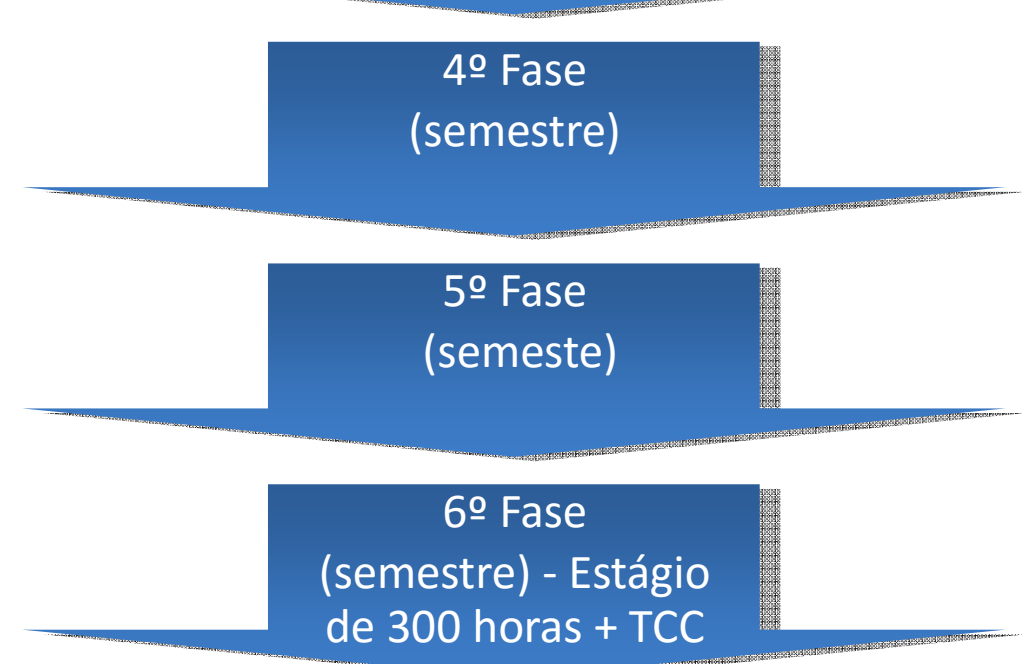


A estrutura curricular do Curso Superior de Tecnologia em Hoteleira do IF-SC, Campus Florianópolis Continente foi desenvolvida com base no perfil dos empreendimentos hoteleiros na atualidade.

Para dar atendimento à demanda do mercado de um profissional com um perfil diferenciado, não só em tecnologia, mas também voltado para o desenvolvimento social, ao final da conclusão da $3^{\circ}$ Fase do curso os alunos receberão uma certificação intermediária. No término do curso os alunos terão desenvolvido todas as competências necessárias para o gerenciamento da operação hoteleira, fazendo jus ao diploma de Tecnólogo em Hotelaria.

O aluno ao final de conclusão da $3^{\circ}$ Fase poderá requerer o certificado de "Qualificação em Operação de Recepção, Reservas e Governança". O aluno terá direito a certificação intermediária mediante conclusão de todos os componentes curriculares até a terceira fase.

Competências relacionadas à certificação

- Identificar no sistema turístico e nas interelações com o mercado hoteleiro o contexto ambiental, social e econômico nas escalas local, regional, nacional e internacional;

- Realizar uma comunicação oral e escrita eficiente e eficaz, utilizando corretamente os termos técnicos e usuais do turismo e da hotelaria com base nos conceitos da hospitalidade e do bem receber;

- Executar as operações técnicas dos setores de Recepção, Governança e Reservas de um meio de hospedagem de turismo, respeitando as normas de segurança do trabalho e higiene.

Os conhecimentos e as habilidades estão descritos nos componentes curriculares das três primeiras fases do curso.

\subsection{Matriz Curricular}

1Fase

\begin{tabular}{|l|c|}
\hline $\begin{array}{l}\text { COMPONENTE CURRICULAR- Introdução ao Turismo e a } \\
\text { Hotelaria }\end{array}$ & CARGA HORÁRIA \\
\hline Fundamentos do Turismo e da Hospitalidade & 72 \\
\hline Linguagem e Comunicação & 72 \\
\hline Introdução à Administração Hoteleira & 72 \\
\hline Economia do Turismo & 72 \\
\hline Língua Espanhola Aplicada & 72 \\
\hline TOTAL & 360 \\
\hline
\end{tabular}

\section{TOTAL}

\section{CARGA HORÁRIA}

COMPONENTE CURRICULAR- Operações na Hotelaria

Operação de Recepção e Reservas 1

Operação de Governança

Segurança do Trabalho

Língua Inglesa Aplicada 1

Sustentabilidade na Hotelaria

Estágio Obrigatório - Etapa 1

\begin{tabular}{|c|c|}
\hline CARGA HORÁRIA \\
\hline 72 \\
\hline & 72 \\
\hline 36 \\
\hline & 72 \\
\hline & 36 \\
\hline 360 \\
\hline
\end{tabular}

3ㅇ Fase

COMPONENTE CURRICULAR - Operações na Hotelaria + CARGA HORÁRIA

Introdução a Gestão Hoteleira

Operação de Recepção e Reservas 2

Alimentos e Bebidas 1 (A\&B1)

Segurança dos Alimentos

Operação de Governança 2

Gestão Financeira

Língua Inglesa Aplicada 2

Gestão de Materiais

TOTAL

\begin{tabular}{|c|c|}
\hline+ & CARGA HORÁRIA \\
\hline & 36 \\
\hline 72 \\
\hline & 36 \\
\hline 36 \\
\hline 72 \\
\hline & 36 \\
\hline
\end{tabular}

\section{$4^{\circ}$ Fase}

\begin{tabular}{|l|l}
\hline COMPONENTE CURRICULAR - Gestão Hoteleira & CARGA HORÁRIA
\end{tabular}

Controladoria

Alimentos e Bebidas 2 (A\&B 2)

Gestão de Eventos na Hotelaria

Gestão de Pessoas

Língua Inglesa Aplicada 3

Sociedade e Trabalho

TOTAL

5 Fase

CURRICULAR-

Empreendedorismo

Marketing Hoteleiro

Gestão da Qualidade e Inovação

Tópicos Especiais

Metodologia da Pesquisa (Pré TCC)

Estatística Aplicada à Hotelaria

Empreendedorismo e Plano de Negócio

Gerenciamento das Receitas (Revenue Management)

TOTAL

6o Fase

COMPONENTE CURRICULAR- Estágio e TCC

Estágio Obrigatório Supervisionado - Etapa 2

Trabalho de Conclusão de Curso - TCC

\section{COMPONENTE CURRICULAR OPTATIVO}

COMPONENTE CURRICULAR

Libras 
SILVESTRE, M. S.; DANTE, P. D. Argentin@: manual de civilización. Madrid: Edelsa, 2009.

WILDNER, A. K; OLIVEIRA, L. C.; SOBOTTKA, M. A. W. Espanhol para o turismo: básico. Volume 1. Florianópolis: Publicações do IFSC: 2014.

\section{Bibliografia Complementar}

BELTRÁN, B. A. El español por profesiones: servicios turísticos. $3^{\underline{a}}$ ed. Madrid: SGEL, 2007.

DOMINGUEZ, P.; BAZO, P. Actividades comunicativas : (entre bromas y veras...). Madrid: Edelsa, 1995.

IGLESIAS CASAL, I. Hagan Juego! Actividades y recursos lúdicos para la enseñanza del español. Madrid: Edinumen, 2007.

MORENO, C., TUTS, M. El español en el hotel. Madrid: SGEL, 2007.

PALOMINO, M. A. Dual: pretextos para hablar. Madrid: Edelsa, 1998

VRANIC, G. Hablar por los codos. Madrid: Edelsa, 2010.

\section{2ํFase - Componentes Curriculares Operações na Hotelaria}

\begin{tabular}{|c|c|}
\hline Disciplina & Operação de Recepção e Reservas 1 \\
\hline Carga Horária & 72 horas \\
\hline & Bases Tecnológicas \\
\hline $\begin{array}{ll}\text { - } & \text { Estrutura f } \\
\text { - } & \text { Atribuições } \\
\text { - } & \text { Procminolos } \\
\text { - } & \text { Software o } \\
\text { - } & \text { Operação } \\
& \text { Service } \\
\text { - } & \text { Reservas } \\
\end{array}$ & $\begin{array}{l}\text { a de recepção e reservas } \\
\text { responsabilidades, cargos e funções de recepção de reservas } \\
\text { dos setores, Técnicas de atendimento e comercialização. } \\
\text { s operacionais de recepção e reservas } \\
\text { ierenciamento Hoteleiro } \\
\text { rotinas nos setores de recepção e reservas, Conciergerie e Guest } \\
\text { viduais e de grupo, através de intermediários e/ou de forma direta. }\end{array}$ \\
\hline & Habilidades \\
\hline $\begin{array}{l}\text { - Identificar } \\
\text { recepção e } \\
\text { - Efetuar pr } \\
\text { check- out } \\
\text { de grupos }\end{array}$ & $\begin{array}{l}\text { ações problemas e apresenta soluções operacionais para o setor de } \\
\text { servas. } \\
\text { dimentos operacionais da recepção tais como: Walk-in, check-in e } \\
\text { ditoria noturna, atendimento de hóspedes VIPs e reservas individuais } \\
\text { avés de intermediários e de forma direta. }\end{array}$ \\
\hline & $\begin{array}{c}\text { Bibliografia } \\
\end{array}$ \\
\hline Bibliografia Bási & \\
\hline $\begin{array}{l}\text { MARQUES, Albar } \\
\text { Thex, 2004. } \\
\text { PÉREZ, Luis Di M } \\
\text { VIERA, Elenara } € \\
\text { Caxias do Sul: Edi }\end{array}$ & $\begin{array}{l}\text { Manual de Hotelaria: políticas e procedimentos. } 2 \text { ed. São Paulo: } \\
\text { Manual prático de recepção hoteleira. São Paulo: Roca, } 2001 . \\
\text { ANDIDO, İ́nio. Gestão de Hotéis: técnicas, operações e serviços. } \\
2003 \text {. }\end{array}$ \\
\hline Bibliografia Com & mentar \\
\hline $\begin{array}{l}\text { CASTELLI, G. Ges } \\
\text { HAYES, David K. } \\
\text { Beth Honorato, Vi } \\
\text { ISMAIL, Ahmed. H } \\
\text { VALLEN, J. J. Ch } \\
\text { Alegre: Bookman, } \\
\text { WALKER, John. Ir }\end{array}$ & $\begin{array}{l}\text { hoteleira. São Paulo: Saraiva, } 2006 . \\
\text { NEMEIER, Jack D. Gestão de operações hoteleiras. Tradução de } \\
\text { Fittipaldi. São Paulo: Pearson Prentice Hall, 2005. } \\
\text { edagem: front Office e Governança. São Paulo: Thompson, } 2004 . \\
\text { in, check-out: gestão e prestação de serviços em hotelaria. Porto } \\
\text { 2. } \\
\text { lução à Hospitalidade. São Paulo: Manole, } 2002 .\end{array}$ \\
\hline
\end{tabular}




\begin{tabular}{|c|c|}
\hline \multicolumn{2}{|r|}{ Operação de Governança 1} \\
\hline Carga Horária & \\
\hline \multicolumn{2}{|r|}{ Bases Tecnológicas } \\
\hline \multicolumn{2}{|c|}{$\begin{array}{l}\text { - Estrutura física e organizacional do setor de Governança, cargos e funções. } \\
\text { - Técnicas operacionais de higienização e arrumação das unidades habitacionais e } \\
\text { - } \text { áreas comuns. } \\
\text { - } \text { Produtos, materiais e equipamentos de uso no setor de Governança. } \\
\text { - Equipamentos e processos de lavanderia: distribuição da roupa e funcionamento da } \\
\text { - lavanderia do hotel; processos de lavação das roupas. } \\
\text { - Manutenção preventiva e corretiva, as interfaces com o setor de Governança. } \\
\text { - Roeração dos serviços prestados pelo setor de Governança. }\end{array}$} \\
\hline \multicolumn{2}{|c|}{ Habilidades } \\
\hline \multicolumn{2}{|c|}{$\begin{array}{l}\text { - Caracterizar os cargos e as funções para equipe de Governança. } \\
\text { - Dimensionar os serviços de Governança conforme a categoria do Hotel. } \\
\text { - Realizar o atendimento aos hóspedes para serviços prestados pela Governança. } \\
\text { - Analisar a estrutura física para operação do setor de Governança, além dos } \\
\text { produtos e materiais necessários, entre os quais, amenities, enxoval de acordo com o } \\
\text { tipo e porte do empreendimento hoteleiro. } \\
\text { - Utilizar as técnicas de limpeza, higienização e de arrumação para realidade } \\
\text { operacional da hotelaria. } \\
\text { - Utilizar os produtos e equipamentos do setor de Governança. } \\
\text { - Aplicar as normas e procedimentos de saúde e segurança do trabalho, utilizando } \\
\text { equipamentos de prevenção individual e coletiva. } \\
\text { - Aplicar os conhecimentos de manutenção preventiva e corretiva inter-relacionados } \\
\text { com o setor de Governança. } \\
\text { - Aplicar os conhecimentos da rotina operacional do setor de Governança. } \\
\text { - Conhecer os processos, os equipamentos e os produtos para lavagem do enxoval } \\
\text { do Hotel. }\end{array}$} \\
\hline \multicolumn{2}{|c|}{ Bibliografia } \\
\hline \multicolumn{2}{|c|}{$\begin{array}{l}\text { Referência Básica } \\
\text { ISMAIL, Ahmed. Hospedagem: front office e governança. São Paulo: Thomson Pioneira, } \\
2004 \text {. } \\
\text { MARTIN, Robert. Governança: administração e operação de hotéis. 3. ed. São Paulo: } \\
\text { Roca, 2005. } \\
\text { VIERA, Elenara e CANDIDO, Índio. Gestão de hotéis: técnicas, operações e serviços. } \\
\text { Caxias do Sul: Educs, } 2003 \text {. }\end{array}$} \\
\hline \multicolumn{2}{|c|}{ Referência Complementar } \\
\hline \multicolumn{2}{|c|}{$\begin{array}{l}\text { CASTELLI, G. Gestão hoteleira. São Paulo: Saraiva, } 2006 \text {. } \\
\text { CAVASSA, César Ramírez. Hotéis: gerenciamento, segurança e manutenção. Tradução de } \\
\text { Claudia Bruno Galvãn. São Paulo: Roca, } 2001 . \\
\text { FARIAS, Roberto Maia. Manual para lavanderias: a revolução na arte de lavar. Caxias do } \\
\text { Sul: EDUCS, 2006. } \\
\text { HAYES, David K.; NINEMEIER, Jack D. Gestão de operações hoteleiras. Tradução de } \\
\text { Beth Honorato, Vivian Fittipaldi. São Paulo: Pearson Prentice Hall, 2005. } \\
\text { OLIVEIRA, Giovanna Bonelli. Camareira: mercado profissional, ambiente de trabalho, } \\
\text { rotina de serviços. Rio de Janeiro: Senac Nacional, } 2010 .\end{array}$} \\
\hline & \\
\hline & \\
\hline
\end{tabular}

- Legislação.

- Equipamentos de prevenção individual e coletiva.

- Identificação de riscos de acidentes no ambiente de trabalho (físico, químico, biológico).

- Ergonomia.

- Causas de acidentes de trabalho.

- Suporte básico de primeiros socorros

Habilidades

- Utilizar os equipamentos de prevenção individual e coletiva.

- Reconhecer os fatores de risco existentes no posto de trabalho.

- Prevenir possíveis acidentes na rotina de trabalho.

- Verificar os controles de riscos ambientais.

- Realizar técnicas de primeiros socorros.

Bibliografia Básica Bibliografia

REIS, Roberto Salvador. Segurança e saude no trabalho. 11. ed. São Caetano do Sul SP: Yendis, 2013.

SCALDELAI, Aparecida Valdinéia. Manual prático de saúde e segurança do trabalho. 2. ed. São Caetano do Sul - SP: Yendis Editora, 2012. .

SUPORTE básico de vida: primeiro atendimento na emergência para profissionais da saúde. Coordenação de Ana Paula Quilici, Sergio Timerman. Barueri: Manole, 2011.

\section{Bibliografia Complementar}

BERGERON, David. J. Primeiros socorros. Tradução de Maria Alice Fortes Gatto, Kazuko Uchikawa Graziano. 2. ed. São Paulo: Atheneu, 2007.

BREVIGLIERO, Ezio; SPINELLI, Robson; POSSEBON, José. Higiene ocupacional: agentes biológicos, químicos e físicos. 6. ed. São Paulo: Senac São Paulo, 2011.

DUL, Jan; WEERDMEESTER, Bernard. Ergonomia prática. Tradução de Itiro lida. 3. ed. São Paulo: Edgard Blücher, 2012

MONTEIRO, Antônio Lopes; BERTAGNI, Roberto Fleury de Souza. Acidentes do trabalho e doenças ocupacionais: conceitos, processos de conhecimento e de execução e suas e doenças ocupacionais: conceitos, processos de
questão polêmicas. 7. ed. São Paulo: Saraiva, 2012.

SOUZA, Lucila Medeiros Minichello de. Primeiros socorros: condutas técnicas. São Paulo: látria, 2010.

- Informacõos pessoais; saudacões formais e informais; atividades diárias.

- Termos técnicos utilizados na hotelaria 1.

- Técnicas e estratégias de leitura em língua estrangeira.

- Tipologia de meios de hospedagem.

- Gêneros textuais da recepção e reservas.

- Questões de sustentabilidade na hotelaria internacional.

- Patrimônio cultural e ambiental de Florianópolis e região.

- Localizacão dos espaços turísticos. 


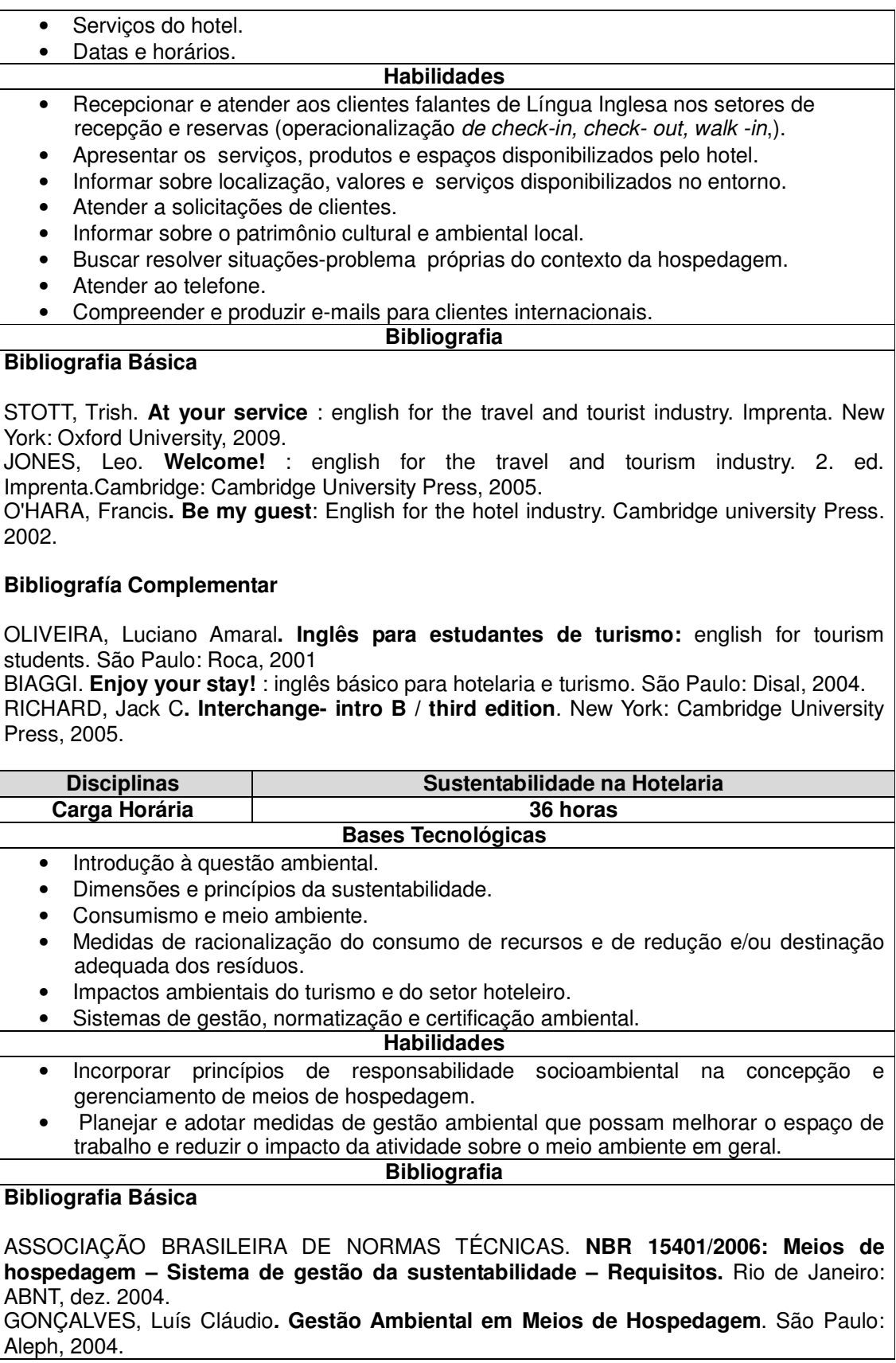

SEIFFERT, M.E.B. ISO 14001 sistemas de gestão ambiental : implantação objetiva e econômica. São Paulo: Atlas, 2009.

\section{Bibliografia Complementar}

FONTES, Nádia et alii. Eventos mais Sustentáveis: uma abordagem ecológica, econômica, social, cultural e política. São Carlos, SP: EdUFSCar, 2008.

PHILIPPI JR, A.; RUSCHMANN, D.V.N. Gestão ambiental e sustentabilidade no turismo. Barueri: Manole, 2010

VLELA JR, A.; DEMAJOROVIC, J. Modelos e ferramentas de gestão ambiental desafios e perspectivas para as organizações. São Paulo: Ed. SENAC São Paulo, 2006. DIAS, Reinaldo. Gestão ambiental: responsabilidade social e sustentabilidade. São Paulo: Atlas, 2010.

PEREIRA, André Luiz. Logística reversa e sustentabilidade. São Paulo: Cengage Learning, 2012.

3 Fase - Componentes Curriculares Operações na Hotelaria + Introdução a Gestão Hoteleira

\begin{tabular}{|c|c|}
\hline Disciplina & Operação de Recepção e Reservas 2 \\
\hline Carga Horária & 36 horas \\
\hline Pré Requisito & Operação de Recepção e Reservas 1 \\
\hline
\end{tabular}

- Software gerenciamento hotele

Gerenciamento de rotinas nos setores de recepção e reservas, conciergerie e guest service.

- Planejamento, organização e supervisão das rotinas diárias dos setores de recepção e reservas.

- Gestão comercial para hotelaria.

- Elaborar ferramentas de registros e de controles para supervisão dos procedimentos.

- Desenvolver procedimentos para atendimento de clientes Vip para o setor de Conciergerie.

- Controlar o fluxo de caixa da recepção.

- Controlar dead line; adiantamentos de reserva; no show; cancelamento e alteração de reservas.

- Utilizar técnicas para negociação e comercialização das reservas:

- Gerenciar os bloqueios (allotment).

- Efetuar a tabulação e avaliação dos opinários dos clientes e estabelecer indicadores para melhoria do atendimento.

- Utilizar tecnologias para gestão da operação dos setores de Recepção e Reservas.

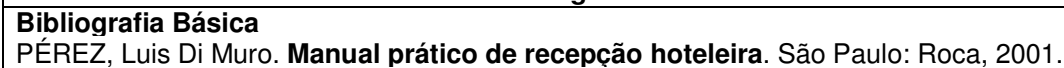
Bibliografia MARQUES, Albano. Manual de Hotelaria: políticas e procedimentos. 2 ed. São Paulo: MARQUES,
Thex, 2004 .

Thex, 2004. Caxias do Sul: Educs, 2003

Bibliografia Complementa 
ISMAIL, Ahmed. Hospedagem: front Office e Governança. São Paulo: Thompson, 2004 WALKER, John. Introdução à Hospitalidade. São Paulo: Manole, 2002.

VALLEN, J. J. Check-in, check-out: gestão e prestação de serviços em hotelaria. Porto Alegre: Bookman, 2002

CASTELLI, G. Gestão hoteleira. São Paulo: Saraiva, 2006.

HAYES, David K.; NINEMEIER, Jack D. Gestão de operações hoteleiras. Tradução de

Beth Honorato, Vivian Fittipaldi. São Paulo: Pearson Prentice Hall, 2005.

\begin{tabular}{|c|c|}
\hline \multirow{2}{*}{$\begin{array}{c}\text { Disciplina } \\
\text { Carga Horária }\end{array}$} & Alimentos e Bebidas I (A\&B I) \\
\hline & 72 horas \\
\hline \multicolumn{2}{|r|}{ Bases Tecnológicas } \\
\hline \multicolumn{2}{|c|}{$\begin{array}{l}\text { - História da alimentação em meios de hospedagem e restaurantes. } \\
\text { - Conceito e tipologia de Restaurantes. } \\
\text { - Produção em A\&B. } \\
\text { - Serviços em A\&B. } \\
\text { - } \text { Servicionalização de A\&B no hotel: café da manhã, brunch, coffee break, room } \\
\text { - Técnicas de venda no restaurante. }\end{array}$} \\
\hline \multicolumn{2}{|c|}{$\begin{array}{c}\text { Habilidades } \\
\end{array}$} \\
\hline \multicolumn{2}{|c|}{$\begin{array}{l}\text { - Identificar a estrutura física, organizacional e operacional dos setores de Alimentos e } \\
\text { Bebidas (A\&B) nos meios de hospedagem. } \\
\text { - Executar produções e serviços em A\&B. }\end{array}$} \\
\hline \multicolumn{2}{|c|}{ Bibliografia } \\
\hline \multicolumn{2}{|l|}{ Bibliografia Básica } \\
\hline \multicolumn{2}{|c|}{$\begin{array}{l}\text { CÂNDIDO, I. VIEIRA, E. V. de. Gestão de hotéis: técnicas, operações e serviços. Caxias do } \\
\text { Sul: Educs: } 2003 \text {. } \\
\text { WALKER, John R. Introdução à hospitalidade. } 2 \text { ed. Barueri: Manole, } 2002 . \\
\text { SEBESS, Mariana. Técnicas da cozinha profissional. } 3 \text { ed. Rio de Janeiro: SENAC, } 2010 .\end{array}$} \\
\hline \multicolumn{2}{|c|}{ Bibliografia Complementar } \\
\hline \multicolumn{2}{|c|}{$\begin{array}{l}\text { BECK, Heinz. Arte e ciência do serviço. São Paulo: Anhembi Morumbi, } 2005 . \\
\text { CANDIDO, I. VIERA, E. V. de. Maître d'hôtel: técnicas de serviço. } 1 \text { ed.Caxias do Sul: } \\
\text { Educs, 2002. } \\
\text { FRANCO, A. De caçador à gourmet: uma história da gastronomia. } 4 \text { ed. São Paulo: Senac, } \\
\text { 2006. } \\
\text { FREUND, F. T. Festas e recepções: Gastronomia, organização e cerimonial. } 1 \text { ed. Rio de } \\
\text { Janeiro: Senac, 2002. } \\
\text { MARICATO, Percival. Marketing para bares e restaurantes. Rio de Janeiro: Senac, } 2009 . \\
\text { ORNELLAS, Lieselotte H. Alimentação através dos tempos. Florianópolis: UFSC, } 2008 .\end{array}$} \\
\hline \multicolumn{2}{|r|}{ Segurança de Alimentos } \\
\hline Carga Horária & \\
\hline \multicolumn{2}{|r|}{ Bases Tecnológicas } \\
\hline $\begin{array}{ll} & \text { Definiçãc } \\
\text { - } & \text { Importân } \\
\end{array}$ & $\begin{array}{l}\text { Alimentos x Segurança Alimentar. } \\
\text { ca de Alimentos para Serviços de A }\end{array}$ \\
\hline
\end{tabular}

\section{- Perigos químicos, físicos e biológicos.}

- Doenças transmitidas por alimentos (DTAs).

- Introdução a legislação sanitária, Boas Práticas, POP e APPCC.

- Higiene pessoal.

- Requisitos higiênico-sanitários para estrutura física.

- Higienização das instalações, dos equipamentos e dos utensílios.

- Qualidade da água para uso na produção de alimentos e bebidas.

- Controle integrado de vetores e pragas urbanas.

- Manejo de resíduos.

- Higiene dos Alimentos: controle e a garantia da qualidade sanitária do produto (seleção de fornecedores, recebimento, armazenamento, pré-preparo, preparo, espera: distribuição; sobras).

\section{Habilidades}

- Aplicar as Boas Práticas para Serviços de Alimentação, com base na legislação sanitária vigente.

\section{Bibliografia Básica}

$$
\text { Bibliografia }
$$

BRASIL. Ministério da Saúde. ANVISA. Resolução RDC $n^{\circ}$. 216, de 15 de setembro de 2004. Dispõe sobre Regulamento Técnico de Boas Práticas para Serviços de

Alimentação. Disponível em

$<$ http://portal.anvisa.gov.br/wps/wcm/connect/4a3b680040bf8cdd8e5dbf1b0133649b/ RESOLU\%C3\%87\%C3\%83O-

$\mathrm{RDC}+\mathrm{N}+216+\mathrm{DE}+15+\mathrm{DE}+\mathrm{SET} E M B R O+\mathrm{DE}+2004$.pdf?MOD=AJPERES $>$ Acesso em $04 / 06 / 2014$.

SANTA CATARINA. Decreto Estadual no. 31.455, de 20 de fevereiro de 1987. Estabelece critérios sobre estabelecimentos que manipulem, comercializem ou transportem alimentos e/ou bebidas. Disponível em

$<$ http://server03.pge.sc.gov.br/LegislacaoEstadual/1987/031455-005-0-1987000.htm>. Acesso em 04/06/2014.

SILVA JUNIOR, E. A. Manual de Controle Higiênico-Sanitário dos Alimentos. $6^{\underline{a}}$ edição, São Paulo: Varela, 2005, 624p.

MANUAL de elementos de apoio para o Sistema APPCC. Rio de Janeiro: SENAC/DN, 2001. $\begin{array}{lll}282 & p \text {. (Qualidade e Segurança Alimentar). } \begin{array}{c}\text { Projeto APPCC Mesa. } \\ \text { Disponível }\end{array} & \begin{array}{r}\text { Convênio } \\ \text { em: }\end{array} \\ \end{array}$

$<$ http://www.ead.sebrae.com.br/premios/BPSA/5/elementos-apoio-sistema-

appcc.pdf $>$ Acesso em 04/06/2014

\section{Bibliografia Complementar}

GERMANO, Pedro Manuel Leal. Higiene e vigilância sanitária de alimentos: qualidade das matérias-primas, doenças transmitidas por alimentos, treinamento de recursos das materias-primas, doenças transmitidas por alimen
humanos/ 4. ed. rev. e atual. Barueri: Manole, 2011. $1034 \mathrm{p}$.

LOPES, T.H. et al. Higiene e manipulação de alimentos. Curitiba: Livro Técnico, 2012. LOPES, $168 \mathrm{p}$.

REY, A. Comer sem riscos 1 : manual de higiene alimentar para manipuladores e consumidores. São Paulo: Livraria Varela, 2009.

SÃO PAULO. Portaria CVS 5, de 09 de abril de 2013. Aprova o regulamento técnico sobre boas práticas para estabelecimentos comerciais de alimentos e para serviços de alimentação, e o roteiro de inspeção. Disponível em $<$ http://www.cvs.saude.sp.gov.br/up/PORTARIA\%20CVS-5 090413.pdf>Acesso em $04 / 06 / 2014$. 


\section{pedido.}

- Compras: Objetivos. Tipos de compras: reativas, pró-ativas. Operacionalização. Fontes de fornecimento. Cadastro de fornecedores. Estratégias.

- Estoque para governança e alimentos e bebidas.

$$
\text { Habilidades }
$$

- Efetuar o planejamento, a organização e o controle de estoque.

- Planejar e realizar compras.

\section{Bibliografia Básica}

\section{Bibliografia}

CAVASSA, César Ramirez. Hotéis: gerenciamento, segurança e manutenção. São Paulo: Roca, 2001.

DAVIES, Carlos Alberto. Cargos em Hotelaria. Caxias do Sul: Educs, 2001.

VIANA. João José. Administração de materiais: um enfoque prático. São Paulo: Atlas, 2009.

\section{Bibliografia Complementar}

DIAS, Marco Aurélio P.. Administração de materiais: princípios, conceitos e gestão. São Paulo: Atlas, 2008

DI MURO PEREZ, L. Manual prático de recepção hoteleira. São Paulo: Rocca, 2001

POWERS, Tom. Administração no setor de hospitalidade: turismo, hotelaria, restaurante. São Paulo: Atlas, 2004.

TORRE, F. de La. Administração hoteleira, parte I.: departamentos. São Paulo: Rocca,

VIERA, Elenara V. Desperdício em Hotelaria. Caxias do Sul: EDUCS, 2004.

4 Fase - Componentes Curriculares: Gestão Hoteleira

\begin{tabular}{|l|l|}
\hline \multicolumn{1}{|c|}{ Cisciplinas } & \multicolumn{1}{c|}{ Controladoria } \\
\hline Carga Horária & \multicolumn{1}{c|}{ Bases Tecnológicas } \\
\hline - & \multicolumn{1}{c|}{ Entendimento dos processos de auditoria e controladoria, importância, } \\
procedimentos, investimento em prevenções contra fraudes. \\
- Conceitos básicos de contabilidade. \\
- Demonstrações contábeis: Balanço Patrimonial e Demonstração do Resultado do \\
Exercício. \\
- Capital Circulante Líquido. \\
- Fluxos de caixa. \\
- Inventários. \\
- Custos: noções básicas, custos fixos e variáveis, diretos e indiretos. \\
- Princípios de custeio: custeio direto (Variável) e custeio por absorção (Rateio). \\
- Formosição das receitas e dos custos na hotelaria. \\
- Análise do ponto de equilíbrio operacional e econômico. \\
- Sistemas de controle: conceitos, exemplos de sistemas e utilização de planilhas \\
eletrônicas para cálculos, registros, controles e análises de resultados. \\
\hline \\
- Saber utilizar os instrumentos de controle e os recursos contábeis utilizados pelas \\
organizações hoteleiras.
\end{tabular}

\section{- Dimensionar os custos operacionais de todos os setores do hotel.}

- Tomar decisões com base nas análises econômico-financeiras.

\section{Bibliografia Básica} Bibliografia

MAGNÉE, Henri. Administração simplificada: para pequenos e médios restaurantes. São Paulo: Livraria Velera, 2005.

OLIVO, Ana Maria. Contabilidade Geral e Gerencial. Conceitos introdutórios para os cursos superiores de tecnologia. Florianópolis: Publicações do IFSC, 2012. No endereço: http://www.ifsc.edu.br/images/pesquisa/livros_do_ifsc/miolos/Livro_contabilidade_miolo.pdf ZANELLA, Luiz Carlos. Auditoria interna: rotinas e processos práticos para hotéis, restaurantes e empresas em geral. Caxias do Sul: Educs, 2002.

\section{Bibliografia Complementar}

ASSAF NETO, Alexandre. Estrutura e análise de balanços: um enfoque econômicofinanceiro. 7 ed. São Paulo: Atlas, 2002.

POWERS, Tom. Administracão no setor de hospitalidade: turismo, hotelaria,

RE

LE http://www.planalto.gov.br/ccivil_03/leis/l6404consol.htm.

VAZ, Célio Silvério. Restaurantes: controlando custos e aumentando lucros. Brasilia: LGE Editada Itda, 2006

VIERA, Eleonora V. Desperdício em Hotelaria. Caxias do Sul: EDUCS, 2004

\begin{tabular}{|c|c|}
\hline Disciplina & Alimentos e Bebidas 2 (A\&B 2) \\
\hline Carga Horária & 72 horas \\
\hline Pré-Requisitos & Alimentos e Bebidas 1 (A\&B 1) e Segurança dos Alimentos \\
\hline & Bases Tecnológicas \\
\hline $\begin{array}{l}\text { - Sistemas de ge } \\
\text { - Planejamento f } \\
\text { - } \text { Gerência de A\& } \\
\text { - } \text { Treinamento e } \\
\text { - } \text { Planejamento } \\
\text { - } \text { Sistroles gere } \\
\text { - } \text { Associaçõoser cc }\end{array}$ & $\begin{array}{l}\text { aplicáveis ao setor de A\&B. } \\
\text { e organizacional em A\&B. } \\
\text { tinas, atribuição e responsabilidades. } \\
\text { ação para o setor. } \\
\text { rdápios. } \\
\text { s em A\&B; } \\
\text { ais para restaurantes. } \\
\text { ciais ligadas ao setor de A\&B. }\end{array}$ \\
\hline & Habilidades \\
\hline $\begin{array}{l}\text { - Planejar e or } \\
\text { - } \text { departamento } \\
\text { - Gerenciar o fur } \\
\text { - Gerenciar a of }\end{array}$ & $\begin{array}{l}\text { me controlar as instalações e os fluxos de serviços no } \\
\text { mentos e Bebidas (A\&B). } \\
\text { amento dos setores de A\&B no hotel. } \\
\text { comercialização dos produtos de A\&B. }\end{array}$ \\
\hline & Bibliografia \\
\hline $\begin{array}{l}\text { 3ibliografia Básica } \\
\text { ASTELLI, Geraldo. C } \\
\text { ONSECA, M. T. Tecr } \\
\text { MARICATO, Percival. } \\
\text { Senac, } 2010 .\end{array}$ & $\begin{array}{l}\text { hoteleira. São Paulo: Saraiva, } 2006 \text {. } \\
\text { a gerenciais de restaurantes. } 5 \text { ed. São Paulo: Senac, } 2009 . \\
\text { montar e administrar bares e restaurantes. } 9 \text { ed. São Paulo }\end{array}$ \\
\hline & \\
\hline
\end{tabular}


MEYER, Dany. Hospitalidade e negócios: o rei da gastronomia de Nova York conta o segredo do sucesso. São Paulo: Novo Conceito Editora, 2007.

MEZOMO IB Os serviços de alimentação. 5.ed. Barueri: Manole, 2002. VASCONCELOS, F.; CAVALCANTE E.; BARBOSA L. Menu: como montar um cardápio VASCONCELOS, F., CAVALCANTE

eficiente. São Paulo: Roca, 2002

Eventos: Planejamento operacionalizaçäo.3.ed. Săo Paulo: Atlas, 2006.

WALKER, John R. Introdução à hospitalidade. 2 ed. Barueri: Manole, 2002.

\begin{tabular}{|c|c|}
\hline & $G$ \\
\hline & \\
\hline \multicolumn{2}{|r|}{ ases $\mathrm{Te}$} \\
\hline \multicolumn{2}{|r|}{$\begin{array}{l}\text { e tipologia de Eventos. Termos técnicos e entidades do setor. } \\
\text { econômicos, sociais e culturais da indústria de eventos. } \\
\text { co do setor. } \\
\text { s eventos - pré, trans e pós. } \\
\text { em meios de hospedagem e a relação com outros setores/departamentos } \\
\text { rviço). } \\
\text { Montagem de Espaços. } \\
\text { entos para eventos. } \\
\text { ores de serviços e produtos para eventos. } \\
\text { to de Orçamentos. Plano comercial. Contrato de prestação de serviços. } \\
\text { rviço. } \\
\text { e Cerimonial e Protocolo. } \\
\text { s para eventos. } \\
\text { e espaços para eventos na hotelaria. }\end{array}$} \\
\hline \\
\hline \multirow{2}{*}{\multicolumn{2}{|c|}{ 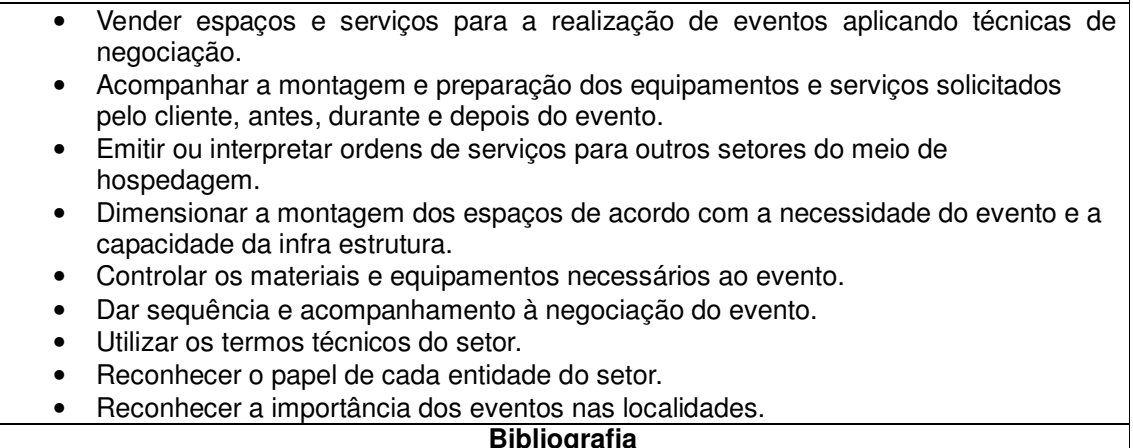 }} \\
\hline & \\
\hline \multicolumn{2}{|l|}{ ibliografia Básic } \\
\hline & \\
\hline
\end{tabular}

GIACAGLIA, Maria Cecília. Eventos: como criar, estruturar e captar recursos. São Paulo: Thomson, 2007

\section{Bibliografia Complementa}

FREUND, Francisco Tommy. Festas e recepções: gastronomia, organização e cerimonial. 2. ed. Rio de Janeiro: Senac Nacional, 2009.

Manual prático de eventos. São Paulo: Atlas, 2003.

SHIBAKI, Viviane Veiga. Planejamento e gestão da mobilidade em grandes metrópoles: reflexões acerca das estratégias do São Paulo Convention \& Visitors Bureau. Revista Turismo: Visão e Ação. V.15., n.01, UNIVALI. 2013. Disponivel em: < http://www6.univali.br/seer/index.php/rtva/article/view/3505>. Acesso em 10 abr 2014. WATT, David C. Gestão de eventos em lazer e turismo. Porto Alegre: Bookman, 2004

YEOMAN, lan. Gestão de festivais e eventos: uma perspectiva internacional de artes e cultura. São Paulo: Roca, 2006.

ZANELLA, Luiz Carlos. Manual de organização de eventos. 4.ed. São Paulo: Atlas, 2008.

\begin{tabular}{|r|r} 
Disciplina & Gestão de Pes \\
\hline Carga Horária & $\mathbf{7 2}$ horas \\
\hline
\end{tabular}

- Organizações como sistemas sociais. Organizações como sistemas abertos: abordagem de Katiz e Kahn; sistema sociotécnico; elementos das organizações; participantes das organizações; objetivos organizacionais; níveis das organizações: ambiente organizacional, geral e tarefa; complexidade e dinâmica ambiental; estratégica organizacional.

- Variabilidade humana: percepção; cognição; Teoria de Campo de Lewin; Teoria da Dissonância Cognitiva; complexa natureza do homem; atitudes; personalidade; aprendizagem.

- Motivação humana: ciclo motivacional; Hierarquia das Necessidades de Maslow; Teoria dos Dois Fatores de Herzberg; Modelo Contingencial de Motivação de Vroom; Teoria de Expectação; clima organizacional.

- Comunicação: comunicação humana; barreiras à comunicação; Janela de Johari e o relacionamento interpessoal e grupal.

- Comportamento humano nas organizações: o homem complexo;

- Processos de gestão de pessoas: Processo de agregar: recrutamento e seleção de pessoas; processo de aplicar: desenho de cargos; avaliação de desempenho;
processo de recompensar: remuneração e benefícios; processo de desenvolver e manter: treinamento e desenvolvimento; administração de conflitos; qualidade de manter: treinamento e
Vida no Trabalho (QVT)

Habilidades

- Identificar e reconhecer a importância dos recursos humanos na produtividade $e$ qualidade do trabalho, assim como as funções táticas e estratégicas nas organizações hoteleiras;

- Utilizar teorias relativas às organizações e ao comportamento das pessoas para gerir equipes de trabalho, bem como relacionar-se no ambiente organizacional

- Gerenciar os processos de agregar, aplicar, recompensar, desenvolver e manter pessoas nas empresas hoteleiras.

Bibliografia

CHIAVENATO, Idalberto. Gestão de pessoas. Rio de Janeiro: Elsevier, 2009.

LACOMBE, Francisco. Recursos humanos: princípios e tendências. São Paulo: Saraiva, 
2011.2008.

\section{Bibliografia Complementar}

CHIAVENATO, Idalberto. Teoria Geral da Administração. São Paulo: Atlas, 2003.

MAXIMIANO Antonio Cesar Amaru. Introdução à Administração. São Paulo: Atlas, 2011.

GARCIA, Adriana Amadeu; ARAUJO, Luis Cesar G. de.. Gestão de pessoas: edição compacta. São Paulo: Atlas, 2010.

GIL, Antônio Carlos. Gestão de pessoas: enfoque nos papéis profissionais. São Paulo: Atlas, 2001.

CLARKE, Alan; CHEN, Wei. Hotelaria: fundamentos teóricos e gestão. Tradução de Renata Christovão Bottino. Rio de Janeiro: Elsevier, 2008.

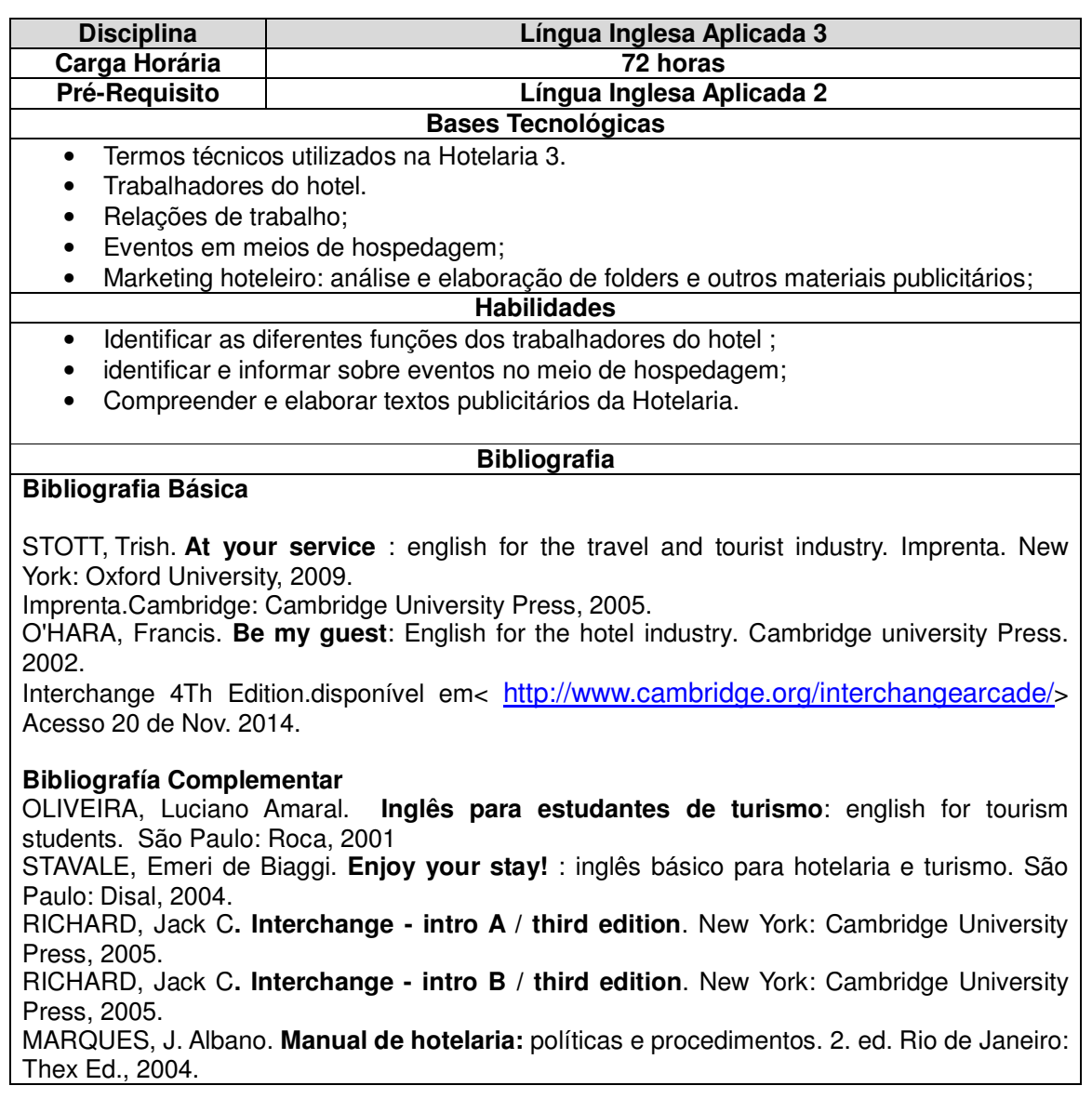

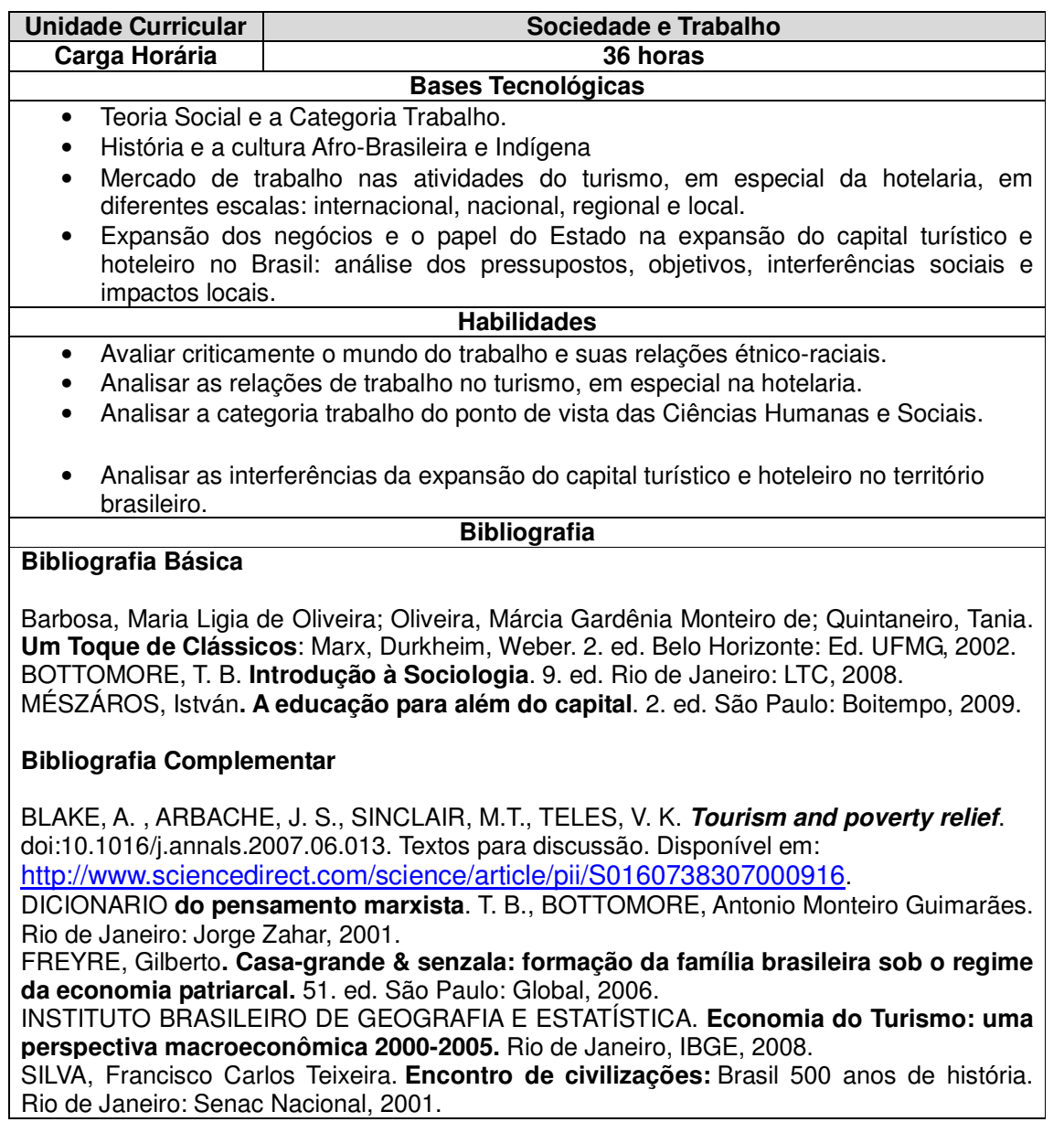

\section{5o Fase - Componentes Curriculares: Tendências na Hotelaria}

\begin{tabular}{|l|l|}
\hline \multicolumn{1}{|c|}{ Disciplina } & \multicolumn{1}{c|}{ Marketing Hoteleiro } \\
\hline Carga Horária & \multicolumn{1}{c|}{$\mathbf{7 2}$ horas } \\
\hline & \multicolumn{1}{c|}{ Bases Tecnológicas } \\
\hline - Fundamentos do marketing ( análise ambiental, orientações de mercado, objetivos \\
do marketing. \\
- Segmentação de mercado (geográfica, psicográfica, demográfica, por situação e por \\
benefício. \\
- Gestão da Oferta (embalagem, rotulagem, gestão da marca) \\
- Gestão da Comunicação de Marketing (propaganda, promoção de vendas, eventos, \\
\hline
\end{tabular}


internet e outras formas de comunicação)

- Gestão da Distribuição (distribuição direta e indireta, relacionamento com intermediários, o papel dos intermediários, internet).

- Gestão do Preço (políticas de preço, sensibilidades de preço, preço x sazonalidade)

- Marketing de relacionamento.

- Consumo e Comportamento do Consumidor em Viagens.

- Captação de Clientes na Hotelaria.

- Plano de Marketing.

\section{Habilidades}

- Identificar as orientações de mercado existentes e o reflexo na hotelaria.

- Identificar as segmentações de mercado existentes e de possível implantação. mercadológica nos meios de hospedagem.

- Relacionar as estratégias de marca, oferta, distribuição, comunicação e preço com a realidade mercadológica do meio de hospedagem.

- Elaborar planos de marketing.

- Identificar possibilidades de captação de clientes em meios de hospedagem.

\section{Bibliografia Básica} Bibliografia

DIAS, Sérgio Roberto (Coord). Gestão de Marketing. São Paulo: Saraiva, 2003. KOTLER, Philip; KELEER, Kevin Lane. Administração de Marketing. 14ª Ed. São Paulo: Pearson Prentice Hall, 2012.

GARDANI, F. Gestão de Marketing na Hotelaria. São Paulo: Atlas, 2006.

\section{Bibliografia Complementar}

MARICATO, P. Marketing para bares e restaurantes. Rio de Janeiro: Senac, 2009. SOUKI, O. Paixão por marketing: o fantástico diferencial dos gênios. Belo Horizonte: Souki House, 2004.

TAVARES, P. V. Marketing fundamentos para a administração pública. Florianópolis: CEFET, 2008 .

ZARDO, E. F. Marketing aplicado ao turismo: ferramentas de marketing para empresas ZARDO, E. F. Marketing aplicado ao turismo: ferramentas

CAON, Mauro. Gestão estratégica de serviços de hotelaria. São Paulo: Atlas, 2008

\begin{tabular}{|c|c|}
\hline \multirow{2}{*}{$\begin{array}{c}\text { Disciplina } \\
\text { Carga Horária }\end{array}$} & Gestão da Qualidade e Inovação \\
\hline & 72 horas \\
\hline \multicolumn{2}{|r|}{ Bases Tecnológicas } \\
\hline \multicolumn{2}{|c|}{$\begin{array}{l}\text { - Abordagens conceituais e dimensões da qualidade. } \\
\text { - } \text { Processo e agentes da gestão da qualidade. } \\
\text { - Estão da qualidade em serviços das atividades de linha de frente e retaguarda. } \\
\text { diagrama de causana-efeito, diagrama de Parada, enquanto conjunto de métodos: } \\
\text { - Normas ISO (International Organization for Standardization) aplicáveis à hotelaria. } \\
\text { - Inovação: conceitos e tipos (de produto, de processo, organizacional e de } \\
\text { marketing). } \\
\text { - Processo de inovação: conceito, fases e gerenciamento. } \\
\text { - Inovação na hotelaria. }\end{array}$} \\
\hline \multicolumn{2}{|r|}{ Habilidades } \\
\hline $\begin{array}{l}\text { - } \text { Gerenciar a c } \\
\text { - Utilizar estrat } \\
\text { - Desenvolver }\end{array}$ & $\begin{array}{l}\text { dade em serviços no contexto da hotelaria. } \\
\text { s relacionadas à gestão da qualidade aplicadas à hotelaria. } \\
\text { vvação no contexto da hotelaria. }\end{array}$ \\
\hline & Bibliografia \\
\hline
\end{tabular}

CLARKE, Alan; CHEN, Wei. Hotelaria: fundamentos teóricos e gestão. Rio de Janeiro: Elsevier, 2008.

Organization for Economic Cooperation and Development. Manual de Oslo: Proposta de Diretrizes para Coleta e Interpretação de Dados sobre Inovação Tecnológica. Disponível

em: <http://www.mct.gov.br/upd blob/0005/5069.pdf>. Acesso em 08 abr 2014.
TIDD, J., BESSANT, J. E PAVITT, K. Gestão da Inovação. Porto Alegre, Bookman, 2008.

\section{Bibliografia complementar:}

ALMEIDA, Cláudia Ribeiro; FERREIRA, Ana Maria; COSTA, Carlos. Gestão integrada do conhecimento no sector turístico: proposta de matriz de análise. PASOS. Revista de $\begin{array}{llcccc}\begin{array}{l}\text { Turismo y } \\ \text { <http://www.pasosonline.org/Publicados/7309special/PS0309 }\end{array} & \text { 11.pdf>. Acesso em } 10\end{array}$ abr 2014.

FREITAS, André Luis Policani; ALMEIDA, Georgia Maria Mangueira de.; Classificação da qualidade de serviços em meios de hospedagem: uma abordagem exploratória. Revista Hospitalidade, Universidade Morumbi Anhembi. V X, n 2, dezembro 2013. Disponivel em: <http://revhosp.org/ojs/index.php/hospitalidade/article/view/528>. Acesso em 08 abr 2014.

RICCI, Renato. Hotel: estratégias competitivas : um guia prático para a aplicação da gestão de processos e do balanced scorecard no segmento da hotelaria e do turismo. Rio de Janeiro: Qualitymark, 2005.

ZONATTO, Vinícius Costa da Silva; SCHUH, Clari;; ZONATTO, Patrinês Aparecida França. Contribuição dos recursos estratégicos nos processos de criação da inovação em uma rede de cooperacao hoteleira. In: Anais do II SINGEP e I S2IS - São Paulo - SP $\begin{array}{llllll}\text { Brasil } & - & 0 & \text { e } & 08 / 11 / 2013 & \text { Disponível el }\end{array}$

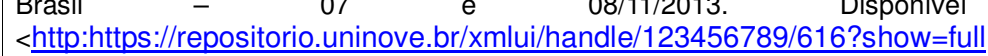

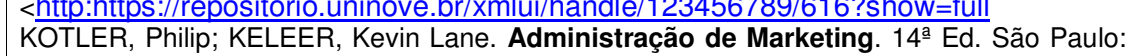
\begin{tabular}{l} 
Pearson Prentice Hall, 2012. \\
\hline
\end{tabular} 


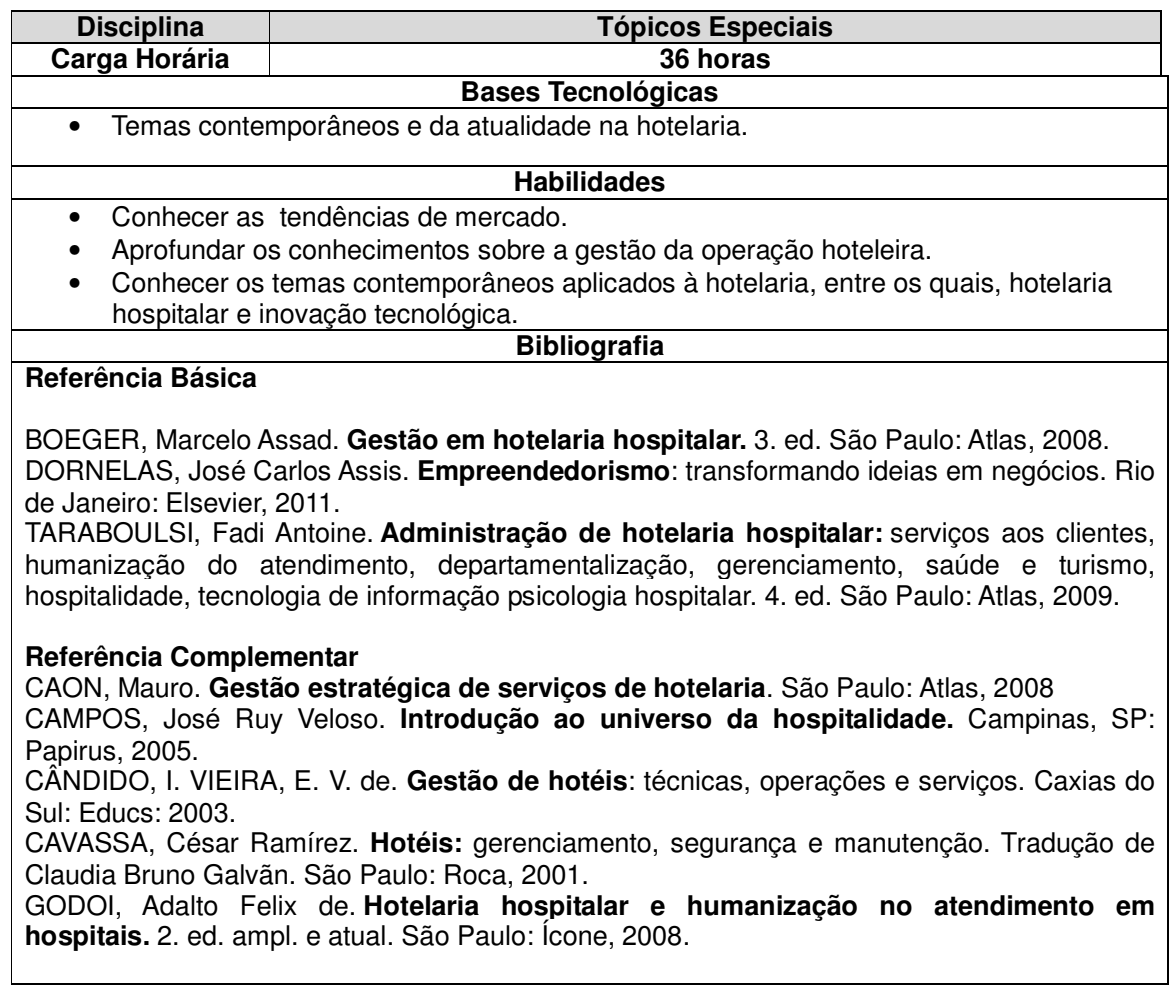

\begin{tabular}{|c|c|}
\hline U & Metodologia da Pe \\
\hline & \\
\hline \multicolumn{2}{|r|}{ Bases Tec } \\
\hline \multicolumn{2}{|c|}{$\begin{array}{l}\text { - Língua padrão oral e escrita. } \\
\text { - Elementos da redação acadêmica baseados nas Normas da ABNT e da Metodologia } \\
\text { científica. } \\
\text { - Diferentes tipos de pesquisas científicas. } \\
\text { Processos comunicativos orais e escritos do contexto acadêmico: teoria e prática para } \\
\text { banca. }\end{array}$} \\
\hline \multicolumn{2}{|c|}{$\begin{array}{c}\text { Habilidades } \\
\end{array}$} \\
\hline \multicolumn{2}{|c|}{$\begin{array}{l}\text { - Usar a comunicação não verbal (corporal etc.) e verbal a favor de uma comunicação } \\
\text { eficiente no contexto acadêmico e profissional. } \\
\text { - Ler e produzir a redação acadêmica caracterizada pela: a) linguagem correta e } \\
\text { precisa; b) coerência na argumentação; c) clareza na exposição de ideias; d) } \\
\text { objetividade; e) concisão e fidelidade às fontes citadas e e) fidelidade aos elementos } \\
\text { estruturais, textuais e linguísticos de cada texto em decorrência da sua função } \\
\text { específica. }\end{array}$} \\
\hline \multicolumn{2}{|c|}{ Bibliografia } \\
\hline \multicolumn{2}{|l|}{ Referência Básica } \\
\hline \multicolumn{2}{|c|}{$\begin{array}{l}\text { MARCONI, M.; LAKATOS, E. M. Metodologia do trabalho científico: procedimentos } \\
\text { básicos, pesquisa bibliográfica, projeto e relatório, publicações e trabalhos científicos. 7. ed.- } \\
\text { São Paulo: Atlas, 2011. } \\
\text { SANTOS, A. R. dos. Metodologia científica: a construção do conhecimento. 7. ed. - Rio de } \\
\text { Janeiro: Lamparina, 2007. } \\
\text { SEVERINO, A. J. Metodologia do Trabalho Científico. 23. ed. rev. e atual. São Paulo: } \\
\text { Cortez, 2007. }\end{array}$} \\
\hline \multicolumn{2}{|c|}{ Referência Complemen } \\
\hline \multicolumn{2}{|c|}{$\begin{array}{l}\text { ASSOCIAÇÃO BRASILEIRA DE NORMAS TÉCNICAS. NBR 6022: Informação e } \\
\text { documentação: artigo em publicação periódica científica impressa: apresentação. Rio de } \\
\text { Janeiro, 2003. } \\
\text { GIL, Antonio Carlos. Como elaborar projetos de pesquisa. 4. ed. São Paulo: Atlas, } 2009 \text {. } \\
\text { OLIVEIRA, Maria Marly de. Como fazer projetos, relatórios, monografias, dissertações e } \\
\text { teses. 5. ed. Rio de Janeiro: Campus, } 2011 . \\
\text { MATIAS-PEREIRA, José. Manual de metodologia da pesquisa científica. 2. ed. São Paulo: } \\
\text { Atlas, 2010. } \\
\text { CERVO, Amado Luiz; BERVIAN, Pedro Alcino; SILVA, Roberto da. Metodologia científica. } 6 . \\
\text { ed. São Paulo: Pearson Prentice Hall, 2007. }\end{array}$} \\
\hline
\end{tabular}

Disciplina

Estatística Aplicada à Hotelaria

Carga Horária 36 horas

- Pesquisa quantitativa: populacão Tecnologicas contínuas; questionário. Amostragem: probabilística e não probabilística; amostragem contínuas; questionário. Amostragem: probabilística e não
aleatória simples e estratificada. Amostragens não aleatórias.

- Cálculo de tamanho de amostras. 


\section{Bibliografia Básica}

CLARKE, Alan; CHEN, Wei. Hotelaria: fundamentos teóricos e gestão. Rio de Janeiro Elsevier, 2008.

SMAIL, Ahmed. Hospedagem front office e governança. São Paulo: Pioneira Thomson Learning, 2004.

POWERS, Tom; BARROWS, Clayton W. Administração no Setor de Hospitalidade. São Paulo, SP. Editora Atlas, 2004.

\section{Bibliografia complementar}

CAON Mauro Gestão estratégica de serviços de hotelaria São Paulo: Atlas, 2008.

KIMES, Sheryl. Total Hotel Revenue Management. HotelExecutive.com. Disponível em http://hotelexecutive.com/business review/3620/total-hotel-revenue-management. Acesso em 14 de novembro 2014

, Klaus. Hotel News Now. Measuring your success in revenue management. 25 jul 2011. Disponível em <http:/www.hotelnewsnow.com/Articles.aspx/6043/Measuring-your success-in-revenue-management\#.TyFHEAEiSpA.blogger> . Acesso em 01 agosto 2012.

LOCKWOOD, A; MEDLIK, S. Turismo e hospitalidade no século XXI. Manole: São Paulo,

MARICATO, Percival. Como montar e administrar bares e restaurantes. 9 ed. São Paulo Senac, 2010.
Optativa

\begin{tabular}{|c|c|}
\hline Disciplina & \\
\hline Competências & $\begin{array}{l}\text { Compreender e utilizar expressões familiares e correntes assim como } \\
\text { enunciados simples que visam satisfazer necessidades imediatas. } \\
\text { Nível A1 do quadro comum europeu. }\end{array}$ \\
\hline $\begin{array}{l}\text { - } \text { Cultura, movi } \\
\text { - } \text { Conversação } \\
\text { profissões, fa } \\
\text { - } \text { Marcações n }\end{array}$ & $\begin{array}{l}\text { Bases Tecnológicas } \\
\text { os sociais e história das pessoas surdas. } \\
\text { ibras em contextos cotidianos: cumprimento, localização, tempo, } \\
\text { números e quantificadores. } \\
\text { nuais emocionais, sintáticas e morfológicas para conversação. } \\
\text { Habilidades }\end{array}$ \\
\hline $\begin{array}{l}\text { - Identificar as } \\
\text { surdas, sinali } \\
\text { - Desenvolver }\end{array}$ & $\begin{array}{l}\text { os da cultura, dos movimentos sociais e da histórico das pessoas } \\
\text { es desta língua. } \\
\text { cia em conversações na Língua Brasileira de Sinais, em nível básico. } \\
\text { Bibliografia }\end{array}$ \\
\hline $\begin{array}{l}\text { PIMENTA, Nelson \& } \\
\text { Editora Vozes, 4. } 4^{\text {a }} \text { Ec } \\
\text { MARQUES, J. Alban } \\
\text { Thex Ed., 2004. } \\
\text { WILCOX, Sherman } \\
\text { Disponivel em: }<\text { http }\end{array}$ & $\begin{array}{l}\text { ADROS, Ronice Muller de. Curso de Libras 1. Rio de Janeiro, RJ. } \\
2010 \text {. } \\
\text { anual de hotelaria: políticas e procedimentos. 2. ed. Rio de Janeiro: } \\
\text { COX, Phyllis Perrn. Aprenda a Ver. Editora Arara Azul. } 2005 \text {. } \\
\text { W.editora-arara-azul.com.br/pdf/livro2.pdf >. Acesso em } 20 \text { nov } 2014 .\end{array}$ \\
\hline \multicolumn{2}{|l|}{ Bibliogra } \\
\hline \multicolumn{2}{|c|}{$\begin{array}{l}\text { DAVIES, Carlos Alberto. Cargos em Hotelaria. Caxias do Sul: Educs, } 2001 . \\
\text { ISMAIL, Ahmed. Hospedagem: front office e Governança. São Paulo: Thompson, } 2004 \\
\text { RAMOS, Clélia Regina. LIBRAS: A Língua de Sinais dos Surdos Brasileiros. Editora Arara Azul } \\
\text { Ltda. Petrópolis: 2006. Disponível em: < http://www.luzimarteixeira.com.br/wp- } \\
\text { content/uploads/2009/06/libras.pdf >. Acesso em } 20 \text { nov } 2014 \text {. } \\
\text { GESUELI, Zilda Maria. LINGUA (GEM) E IDENTIDADE: A SURDEZ EM QUESTÃO. Educ. } \\
\text { Soc., Campinas, vol. 27, n. 94, p. 277-292, jan./abr. } 2006 \text {. Disponível em: < } \\
\text { http://www.scielo.br/pdf/es/v27n94/a14v27n94.pdf >. Acesso em } 20 \text { nov } 2014 . \\
\text { VIERA, Elenara e CANDIDO, İndio. Gestão de Hotéis: técnicas, operações e serviços. Caxias } \\
\text { do Sul: Educs, 2003. }\end{array}$} \\
\hline
\end{tabular}

5.8 Atividades complementares

Não se aplica.

5.9 Avaliação do Processo Ensino Aprendizagem 
O processo de avaliação é processual e formativo e atenderá às proposições da Educação Profissional, ou seja, avaliará as competências adquiridas sob os aspectos de conhecimentos, atitudes e habilidades, através dos seguintes instrumentos:

\section{a) ter frequência mínima de $75 \%$}

b) escrita - provas, trabalhos individuais e de grupo, relatórios:

c) oral - simulação de situações reais, participação em sala de aula, apresentação de trabalhos individuais e de grupo, seminários.

A avaliação da aprendizagem terá por finalidade promover o avanço educacional do aluno, aprimorando o processo de aprendizagem, tanto individualmente quanto coletivamente. Os instrumentos de avaliação serão diversificados e constarão no planejamento do componente curricular, estimulando o aluno à: pesquisa, reflexão, iniciativa, criatividade, laboralidade cidadania.

As avaliações serão organizadas baseadas nos seguintes princípios: a avaliação será diagnóstica, processual, formativa e diversificada. Para além dos conhecimentos e habilidades definidos em cada componente curricular será considerado também, como critério de avaliação, as atitudes gerais entre as quais, trabalhar em equipe; respeitar a comunidade escolar; cumprir as tarefas solicitadas, respeitando os prazos; contribuir para as aulas com interesse e empenho; zelar pelo patrimônio escolar e demonstrar iniciativa nas aulas.

A avaliação é importante para o aluno, pois possibilita acompanhar a sua trajetória acadêmica e para o professor a obtenção de indicativos que sustentem as tomadas de decisões sobre os processos de ensino e aprendizagem.

De acordo com a Organização Didática da Campus Florianópolis-Continente, a avaliação prim pelo caráter diagnóstico e formativo, consistindo em um conjunto de ações que permitam recolher dados, visando à análise da constituição das competências por parte do aluno, previstas no projeto de curso. Suas funções primordiais são:

a) obter evidências sobre o desenvolvimento do conjunto de conhecimentos, habilidades $e$ titudes necessárias à constituição de competências, visando à tomada de decisões sobre encaminhamento dos processos de ensin encaminhamento dos semestre seguinte;

b) analisar a consonância do trabalho pedagógico com as finalidades educativas previstas no Projeto Pedagógico do Curso;

c) estabelecer previamente, por componente curricular, critérios que permitam visualizar os avanços e as dificuldades dos alunos na constituição das competências.

Os critérios servirão de referência para o aluno avaliar sua trajetória e para que o professor tenha indicativos que sustentem tomadas de decisões sobre o encaminhamento dos processos de ensino e aprendizagem e a progressão dos alunos. Os registros das avaliações são feitos de acordo com a nomenclatura que segue:

E - Excelente: quando o aluno ultrapassa as expectativas quanto à aquisição da Competência $\mathrm{P}$ - Proficiente: quando o aluno supera os parâmetros mínimos requisitados para a construção da competência

S - Suficiente: quando o aluno atinge os parâmetros mínimos requisitados para a construção da competência.

1 - Insuficiente: quando o aluno não atinge os requisitos mínimos para a aquisição da competência.

As avaliações são realizadas no decorrer da fase e na conclusão do componente curricular correspondente. $O$ discente receberá o conceito apto ou não apto, de acordo com o resultado alcançado durante o processo ensino-aprendizagem.

A avaliação final da fase será feita em reunião específica, com a presença de todos os professores que trabalharam os componentes curriculares.

O registro, para fins de documentos acadêmicos, será efetivado ao final de cada fase, apontando a situação do aluno no que se refere à constituição de competências e utilizando-se a seguinte nomenclatura:

A - (Apto): quando o aluno tiver obtido as competências.

NA - (Não Apto): quando o aluno não tiver obtido as competências.

A recuperação de estudos compreenderá a realização de novas atividades pedagógicas no decorrer do período letivo, que possam promover a aprendizagem. As novas atividades ocorrerão, preferencialmente, no horário regular de aula, podendo ser criadas estratégias alternativas que atendam necessidades específicas, tais como atividades sistemáticas em horário de atendimento paralelo e estudos dirigidos. Ao final dos estudos de recuperação, o aluno será submetido à avaliação, cujo resultado deverá ser registrado pelo professor.

Trancamento: $\mathrm{O}$ trancamento de matrícula será regido pela Organização Didática do Campus.

O tempo para integralização: $O$ aluno terá o dobro do período de integralização previsto no PPC para cumprir os requisitos do curso, sob pena de cancelamento da matrícula.

O sistema de avaliação do processo de ensino aprendizagem no curso Superior de Tecnologia em Hotelaria far-se-á de acordo com as normas estabelecidas pela Organização Didática do Campus. A partir da publicação do Regulamento Didático Pedagógico (RDP) do IFSC a avaliação do processo de ensino e aprendizagem passará a seguir as normas estabelecidas por este documento.

\subsection{Trabalho de Curso}

O Trabalho de conclusão de curso TCC - preconiza um ensino contextualizado e científico, privilegiando a conquista das competências, conhecimentos, atitudes e habilidades, envolvendo 0 discente em atuação competente e embasada na metodologia científica, junto aos diversos segmentos da sociedade.

O Trabalho deverá fazer uso de métodos científicos na pesquisa, investigação, utilização das f Trabalho deverá fazer uso de métodos científicos na pesquisa, investigação, utilização das Científico com possibilidades de publicação.

O TCC será desenvolvido na sexta fase do curso. Fase esta, reservada para a elaboração do Trabalho de Conclusão e da realização do estágio obrigatório. Salienta-se ainda que a pesquisa relacionada ao TCC possa estar vinculada ao campo de estágio ou não, mas, impreterivelmente, deve se relacionar com a área de formação do curso, e especialmente, aos conhecimentos apreendidos sobre a Hotelaria.

O desenvolvimento temático possibilitará a interação do discente nas diversas situações e problemas encontrados, articulando e aplicando os conhecimentos adquiridos, bem como a aproximação da escola com a comunidade, cumprindo, dessa forma, o papel social na formação de um cidadão consciente.

Os discentes poderão se inserir em diferentes áreas de pesquisa na Hotelaria, de acordo com a atuação dos orientadores e o campo de estágio escolhido, com o objetivo de consolidar os 
conteúdos desenvolvidos no decorrer do curso.

O aluno poderá optar por realizar concomitantemente ao estágio a pesquisa para o TCC

A opção de não vincular o TCC ao estágio evidencia a necessidade de trabalhar pesquisas em áreas correlatas tais como, ciências humanas, ciências da saúde, ciências da natureza, entre outras. Existe pouca publicação científica na área de hotelaria e se o campo de pesquisa for mais outras. Existe pouca publicação científica na área de hotelaria e se o campo de pesquisa for mais maiores possibilidades de publicações e um avanço em questões primordiais para a consolidação maiores possit

O TCC será realizado individualmente, sob orientação de um professor de sua escolha que tenha disponibilidade de horário e que tenha afinidade acadêmica com a área de pesquisa. Ao final da fase, o aluno deverá entregar o TCC em três cópias impressas, cópia digital e participará de uma banca examinadora.

O Curso de Tecnologia em Hotelaria possuirá um Manual de Elaboração do Trabalho de Conclusão de Curso, que será elaborado de acordo com as normas da ABNT e temáticas vinculadas aos conhecimentos trabalhados no curso.

A característica multidisciplinar no eixo tecnológico de hospitalidade e lazer, com a necessidade cada vez maior de práticas interdisciplinares em seus processos de produção, divulgação aplicação do conhecimento científico, envolvendo, incorporando e dialogando com variadas outras áreas do conhecimento, faz com que seja relevante colocar à disposição informaç̃es pertinentes sobre tipos de pesquisas, formas de divulgação científica e normas para referências bibliográficas citacões, estas questões serão apresentadas na quinta fase do curso, na disciplina de Metodologia Científica e da Pesquisa.

O Trabalho de Conclusão de Curso, a partir do exposto, cumpre com sua missão de fazer com que o discente pesquise assuntos que foram vistos ao longo do curso, e fazendo desta pesquisa mais um requisito para a obtenção do título superior de Tecnólogo em Hotelaria.

\subsection{Projeto integrador}

\section{Não se aplica}

\subsection{Estágios curricular e acompanhamento do estágio}

Esta seção constitui-se em um instrumento que possa orientar e normatizar as atividade desenvolvidas pelo/a estagiário/a, considerando que o/a mesmo/a encontra-se em um período de transição, ou seja, ainda é estudante, mas já é quase um profissional da hotelaria, necessitando traduzir na prática os conhecimentos adquiridos durante seu período de estudos. Nesse contexto, o estágio possibilita a integralização do processo pedagógico no curso Superior de Tecnologia em Hotelaria e tem por finalidade vivenciar a realidade administrativa e operacional por meio do contato direto com a prática profissional.

Segundo a Lei 11.788 de 25 de setembro de 2008, o estágio é ato educativo escolar, supervisionado, desenvolvido no ambiente de trabalho, que visa à preparação de trabalho produtivo de educandos que estejam frequentando o ensino regular em instituições de educação superior, de educacão profissional, de ensino médio da educacão especial, dos anos finais do ensino fundamental, na modalidade profissional da educação de jovens e adultos.

O Estágio Supervisionado busca a articulação dos conhecimentos apreendidos e as habilidades - Estág lo Supervisionado busca a articulaça dos cótica profissios apreendidos e as habilidades tem um requisilo obrigatorio para conclusão do Curss dividido em duas etapas de realização:
1ํ Estágio Supervisionado I - ao final da $2^{\circ}$ Fase, onde o aluno terá 72 horas de estágio, para vivenciar as questões da operação hoteleira.

2ํㅡㄹ Estágio Supervisionado II - ao final da conclusão de todos os componentes curriculares na $6^{\circ}$ Fase, com 300 horas, onde o aluno além de vivenciar a operação, terá contato com ferramentas de gestão dos meios de hospedagem.

A carga horária total de Estágio do Curso Superior de Tecnologia em Hotelaria é de 372 horas.

São objetivos do Estágio Supervisionado:

- proporcionar a adequação prática dos conhecimentos recebidos em sala de aula para exercício efetivo da atividade profissional, ligada ao turismo e a hotelaria;

- favorecer a experiência prática monitorada e supervisionada, facilitando a apropriação do saber-fazer, a construção de competências e o desenvolvimento de habilidades profissionais;

- proporcionar ao/a estudante oportunidades reais para conduzir a uma postura profissional adequada;

- desenvolver no/a estagiário/a capacidade criativa na sua área de conhecimento;

O campus Florianópolis-Continente possui termos de compromissos firmados para realização de Estágios Supervisionados com alguns hotéis da região de Florianópolis, entre os quais os hotéis: lbis Florianópolis; Ibis São José; InterCity Premium Florianópolis; Hotéis Costa Norte; Baía Norte Palace Hotel; Hotel Castelmar; Ponta dos Ganchos Exclusive Resort; Golden Executive; Oscar Hotel; Slaviero Via Catarina; Kennedy Executive e entre outros.

Nos estágios supervisionados o aluno deverá passar por no mínimo dois setores na empresa hoteleira na mesma área ou em áreas diferentes.

Constituem condicões mínimas para uma empresa hoteleira ser aceita como local para desenvolvimento das atividades do estágio supervisionado: ser legalmente constituída e possuir estrutura física, operacional e administrativa que possibilite o desenvolvimento das habilidades práticas apreendidas no decorrer do curso; dispor de profissionais qualificados para supervisão das atividades realizadas pelo aluno enquanto estagiário; possuir boa reputação idoneidade mora e legal; apresentar recursos materiais e técnicos que possam ser utilizados pelo estagiário no desenvolvimento do seu trabalho.

Condicionado às ofertas existentes o aluno terá a possibilidade de escolher o seu local de estágio de acordo com a sua área de interesse. Durante a realização dos estágios Supervisionados do curso de Tecnologia em Hotelaria o aluno terá um Supervisor na Empresa hoteleira, que será um profissional capacitado e responsável por ele no local de estágio e um Professor Orientador. Somente na primeira etapa do Estágio Supervisionado, que acontece ao final da $2^{\circ}$ fase do curso, além do Supervisor do Estágio na empresa e do Professor Orientador haverá o Professor Supervisor do Estágio que é responsável pela organização do estágio e intermediação entre empresa, aluno e professor orientador.

Compete aos/as docentes orientadores de Estágio: acompanhar o processo de adaptação e as atividades de observação e prática dos/as estagiários/as nos locais de estágio quando possível: realizar um encontro semanal presencial ou a distância (quando o aluno estiver impossibiltado de relizar umer oriaño presta manter contato com o/a supervisor/a da empresa concedent; pa qualificação para orientação de estágios.

Compete ao supervisor da empresa hoteleira concedente: acompanhar o aluno durante a realização do estágio; zelar pelo aluno na empresa; proporcionar um ambiente que possibilite desenvolvimento das habilidades técnicas no decorrer estágio 
São deveres do/a estagiário/a: cumprir todas as etapas nos prazos previstos nos programas dos estágios; comparecer a todos os encontros com o/a Supervisor/a Acadêmico/a para orientação; manter a ética profissional no que diz respeito a assuntos sigilosos da empresa e relacionamento manter a ética
interpessoal;

Após a conclusão do estágio o aluno deverá obrigatoriamente apresentar o relatório das atividades desempenhadas sob a supervisão do professor orientador.

O estágio não obrigatório aquele desenvolvido como atividade opcional no decorrer do curso seguirá os trâmites previstos na Lei 11.788 de 25 de setembro de 2008 e ficará sob a coordenação de estágio a sua organização que elegerá um professor para supervisão das atividades. Ressalta-se que o estagio não obrigatório não contará na carga-horária do curso porque no momento da sua realização o aluno encontra-se em processo de desenvolvimento das habilidades e atitudes técnicas e profissionais.

\subsection{Prática supervisionada nos serviços ou na indústria, e acompanhamento das práticas} supervisionadas

Não se aplica.

\subsection{Atendimento ao discente}

$\mathrm{O}$ atendimento pedagógico e administrativo acontecerá nos turnos de funcionamento do curso. O atendimento por docentes denominado "atendimento extraclasse" está previsto na Resolução 13 do IFSC, onde cada docente receberá de 1 a 2 horas semanais para executá-lo. Ess atendimento inclui atividades e programas de nivelamento para alunos. Além disso, o Campus Florianópolis-Continente do IFSC conta com atendimento ao discente por meio do Núcleo Pedagógico formado por equipe interdisciplinar formado pelos seguintes profissionais: uma psicóloga quatro três pedagogas e uma assistente social O atendimento ao discente funciona pela equipe pedagógica do local e horário de atendimento aos alunos.

\subsection{Atividades de Tutoria (para cursos EAD)}

Não se aplica.

\subsection{Critérios de aproveitamento de conhecimentos e experiências anteriores}

Ao matricular-se na fase, o aluno poderá apresentar requerimento ao respectivo Coordenador de Curso e solicitar aproveitamento de estudos concluídos com êxito por componente curricular. As normas para aproveitamento de competências e experiências anteriores será regulamentada partir do Regulamento Didático Pedagógico (RDP) do IFSC.

As validações serão auferidas para concluintes ou estudantes que já haviam cursado componentes curriculares no ensino superior que requerem a Coordenação de Curso a validação de disciplina covalente. Para análise do processo de aproveitamento o aluno deve apresentar histórico escolar do curso e os respectivos planos de ensino das disciplinas requeridas. Conforme a necessidade, no decorrer do processo pode-se solicitar ao requerente a realização de testes avaliativos (prático, oral e ou escrito). Mediante a analise dos documentos comprobatórios Coordenação do Curso defere ou indefere o requerimento.

\subsection{Avaliação do Projeto Pedagógico do Curso}

O Curso de Tecnologia em Hotelaria será avaliado de diferentes maneiras e públicos. Ao longo do curso, projeta-se que ocorram avaliações semestrais com discentes e docentes, com o intuito de levantar possíveis melhorias e mitigar possíveis riscos que se possa correr. A avaliação - em âmbito do curso é de responsabilidade da coordenaccão, docentes e discentes, mediante encontros, reuniões, depoimentos e registros visando realizar manutenção e reforço de aspectos positivos, adaptações e correções das fragilidades e incremento de potencialidades, conforme as necessidades identificadas.

Tal avaliação será elaborada a partir da vivência dos professores e coordenador (a) do curso e da própria área profissional. Formulários diferentes serão aplicados para alunos e professores e a partir dos resultados, ações de melhoria serão tomadas. Além disso, fóruns de discussão poderão partir dos resultados, açoes de melhoria serão tomadas. Alem disso, foruns de discussão poderão
ser realizados com discentes, docentes e profissionais da área para discussão das diretrizes do ser realize
curso.

Após a formação e conclusão da primeira turma, o curso será revisto com todo o corpo docente, incluindo as avaliações dos semestres anteriores e as mudanças que ocorreram.

Os egressos formados serão pesquisados para verificar a absorção do mercado e a percepção que os mesmos têm de sua formação. Os alunos evadidos do curso também deverão ser pesquisados para investigar os motivos do abandono.

Ressaltam-se nesse processo os efeitos imediatos e significativos para dinâmica do projeto pedagógico obtidas pela oportunidade de professores e alunos avaliarem de maneira integrada problemas comuns, comprometidos com a elaboração de propostas de melhoria do curso.

O projeto do curso será avaliado a cada semestre, sendo possíveis adequações e aprimoramentos. As propostas serão discutidas no Núcleo Docente Estruturante (NDE), no Colegiado do Curso e em reuniões pedagógicas com docentes do curso, coordenações envolvidas e gestores da escola. As reuniões acontecerão periodicamente e constarão no calendário acadêmico. Cabe ao Coordenador do Curso atender discentes e docentes no que se refere a assuntos relacionados ao curso e levá-los a discussão ao NDE. Compete ao NDE realizar reuniões no minimo a cada dois meses com intuito de acompanhar e ajustar o projeto do curso.

\subsection{Incentivo a pesquisa, a extensão e a produção cientifica e tecnológica}

O curso superior em Tecnologia em Hotelaria se propõe a expandir a cultura de pesquisa e da extensão, estimulando os alunos a serem também pesquisadores da área. Nesse contexto, a visão do curso superior em Tecnologia em Hotelaria é de desenvolver projetos técnico-científicos de forma multi e interdisciplinar, com forte integração entre as áreas do curso, incentivando os alunos à produção do conhecimento e a participação deles em conjunto com os professores de alunos à produção do conhecimento e a participação deles em conjunto com os professores de programas institucionais de bolsas de iniciação científica e de outros programas de fomento pesquisa e a extensão. Busca-se a utilização dos projetos de pesquisa e extensão com
experiencias de ensino e aprendizagem permanentes, vinculados aos componentes curriculares.

Conforme a Lei de Diretrizes e Bases № 9.394/1996, no capítulo IV, art. 43: a educação superior tem por finalidade promover a extensão, aberta à participação da população, visando à difusão das conquistas e benefícios resultantes da criação cultural e da pesquisa científica e tecnológica geradas na instituição.

Cabe destacar que o relacionamento com o mercado é condição básica para o sucesso de um curso na área de turismo, hospitalidade e lazer. A partir do surgimento do Campus FlorianópolisContinente tem-se estabelecido relacionamento com entidades e empresas para divulgação da oferta de cursos, visitas técnicas e aulas práticas.

O desenvolvimento de ações de Extensão apresenta-se como proposta de integração entre os alunos, a área profissional e a comunidade, por meio do estabelecimento de parcerias. O estímulo à participação dos alunos na problemática social e na integração com diversos setores da sociedade concebe-se com ações integradas baseadas em necessidades apresentadas que promovam a troca de experiências e de conhecimento.

5.19 Integração (rede pública/licenciatura, rede regional e SUS/saúde, empresas) Não se aplica. 


\section{CORPO DOCENTE E TUTORIAL}

\subsection{Coordenador do Curso}

Coordenação do Curso: Prof ${ }^{\mathrm{a}}$ Fabíola Martins dos Santos

E-mail: fabiola@ifsc.edu.br

Telefone: (48) 38778430

Titulação: Doutora em Geografia e Mestre em Turismo e Hotelaria

Formação acadêmica: Bacharel em Turismo e Hotelaria

Regime de trabalho: 40 horas (DE)

Dedicação à coordenação do curso: 25 horas

Possui graduação em Turismo e Hotelaria pela Universidade do Vale do Itajaí (UNIVALI), Especialização em Marketing para Gestão Empresarial pela Universidade Federal de Santa Catarina (UFSC), Especialização em Planejamento e Gestão Hoteleira pela Universidade do Vale do Itajaí (UNIVALI), Mestrado em Turismo e Hotelaria pela Universidade do Vale do Itajaí Doutorado em Geografia pela Universidade do Federal de Santa Catarina (UFSC), com a tese intitulada "Geografia das Redes Hoteleiras: Mundo, Brasil e Santa Catarina". Possui experiência em cursos no nível Superior da Educação nas áreas de Turismo e Hotelaria, tendo trabalhado como docente no curso de Bacharelado em Hotelaria na Faculdade ASSESC; no curso de Bacharelado em Turismo e Lazer da Universidade Regional de Blumenau (FURB), no curso de Bacharelado em Turismo e Hotelaria da Universidade do Vale do Itajaí (UNIVALI) e no curso Superior em Tecnologia em Cosmetologia da mesma universidade. Nas respectivas universidades, além da docência, exerceu atividades de orientação de estágios e trabalhos de conclusão de curso coordenação de laboratório, coordenacão de projetos interdisciplinares, elaboração de projetos pedagógicos e organização de eventos.

\subsection{Corpo Docente}

Todos os docentes abaixo citados têm regime de trabalho de 40horas/semanais, com dedicação exclusiva.

\begin{tabular}{|c|c|c|}
\hline Nome & Formação / Área de Atuação & Titulacão \\
\hline Ângela Faria Brognoli & Professora de Língua Inglesa & $\begin{array}{l}\text { - Graduação em Letras: } \\
\text { Licenciatura Português e } \\
\text { Inglês } \\
\text { - Mestrado em Letras }\end{array}$ \\
\hline Débora Beron Pinto & $\begin{array}{l}\text { Professora de Serviços de } \\
\text { Restaurante e Bar }\end{array}$ & $\begin{array}{l}\text { - Graduação em Turismo } \\
\text { - Mestre em Turismo }\end{array}$ \\
\hline $\begin{array}{l}\text { Deosir Flávio Lobo de Castro } \\
\text { Júnior }\end{array}$ & $\begin{array}{l}\text { Professor de Ciências Sociais } \\
\text { Aplicadas }\end{array}$ & $\begin{array}{ll} & \text { Bacharel em } \\
& \text { Administração } \\
\text { - } & \text { Mestre em Gestão } \\
& \text { Estratégica Empresarial } \\
\text { - } & \text { Doutorado em } \\
& \text { Administração e Turismo }\end{array}$ \\
\hline Emilaura Alves & Professora de Nutrição & $\begin{array}{l}\text { - } \text { Bacharel em Nutrição } \\
\text { - } \quad \text { Mestre em Nutrição } \\
\end{array}$ \\
\hline Fabíola Martins dos Santos & Professora de Hotelaria & $\begin{array}{ll}\text { - } & \text { Bacharel em Turismo e } \\
& \text { Hotelaria } \\
\text { - } & \text { Especialista em } \\
& \text { Marketing para Gestão } \\
& \text { Empresarial } \\
\text { - Especialista em }\end{array}$ \\
\hline
\end{tabular}

\begin{tabular}{|c|c|c|}
\hline & & $\begin{array}{ll}\text { Planejamento e Gestão } \\
\text { Hoteleira } \\
\text { - Mestre em Turismo e } \\
\text { Hotelaria } \\
\text { - } \text { Doutorado em Geografia } \\
\end{array}$ \\
\hline Fernando Goulart Rocha & Professor Ciências Humanas & $\begin{array}{l}\text { - } \text { Bacharel e Licenciado em } \\
\text { Geografia } \\
\text { - Mestrado em Geografia } \\
\text { - } \text { Doutorado em Geografia } \\
\end{array}$ \\
\hline Jane Parisenti & Professor de Nutrição & $\begin{array}{l}\text { - Graduação em Nutrição } \\
\text { - Mestre em Nutrição } \\
\text { - Doutora em Ciências dos } \\
\text { Alimentos } \\
\end{array}$ \\
\hline Larice Steffen Peters & $\begin{array}{c}\text { Professora de Ciências Sociais } \\
\text { Aplicadas }\end{array}$ & $\begin{array}{ll}- & \text { Graduação em } \\
& \text { Administração Pública } \\
\text { - } & \text { Mestrado em Arquitetura } \\
\text { em Urbanismo }\end{array}$ \\
\hline Laura Lima & Professora de Língua Espanhola & $\begin{array}{l}\text { - } \text { Bacharel e Licenciada } \\
\text { - em Letras: Português e } \\
\text { Espanhol } \\
\text { - Mestre em Linguística } \\
\end{array}$ \\
\hline Liz Cristina Camargo Ribas & Professora de Gestão Ambiental & $\begin{array}{l}\text { - Bacharel e Licenciada em } \\
\text { Ciências Biológicas } \\
\text { - Mestre em Biotecnologia }\end{array}$ \\
\hline Luciane Patrícia Oliari & $\begin{array}{l}\text { Professora de Primeiros } \\
\text { Socorros }\end{array}$ & $\begin{array}{ll} & \text { Bacharel em } \\
\text { Enfermagem } \\
\text { - Especialista em } \\
\text { Enfermagem do Trabalho } \\
\text { - Especialista em } \\
\text { Educação Profissional } \\
\text { Integrada á Educação } \\
\text { Básica na Modalidade } \\
\text { Jovens e Adultos. } \\
\end{array}$ \\
\hline Luciano de Azambuja & Professor de Ciências Humanas & $\begin{array}{ll}\text { - } & \text { Graduação em História } \\
\text { - Especialista em Leitura } & \text { de Múltiplas Linguagens } \\
\text { - Mestrado em Literatura } \\
\text { - } \text { Doutorado em Educação }\end{array}$ \\
\hline Pedro José Raymundo & $\begin{array}{c}\text { Professor de Ciências Sociais } \\
\text { Aplicadas }\end{array}$ & $\begin{array}{ll}\text { - } & \text { Bacharel em } \\
\text { Administração } \\
\text { - } \text { Bacharel em Ciências } \\
\text { Econômicas } \\
\text { - Mestre em Engenharia } \\
\text { da Produção } \\
\end{array}$ \\
\hline $\begin{array}{l}\text { Thianne Durand Mussoi de } \\
\text { Freitas }\end{array}$ & Professora de Hotelaria & $\begin{array}{l}\text { - } \text { Bacharel em Turismo: } \\
\text { Gestão Hoteleira } \\
\text { Especialista em } \\
\text { Marketing para Gestão } \\
\text { Empresarial } \\
\text { Mestre em Turismo e } \\
\text { Hotelaria }\end{array}$ \\
\hline Tiago Savi Mondo & Professor de Hotelaria & $\begin{array}{c}\text { Doutor em } \\
\text { Administração }\end{array}$ \\
\hline
\end{tabular}




\begin{tabular}{|c|c|c|}
\hline & & $\begin{array}{ll}\text { - } & \text { Mestre em } \\
& \text { Administração } \\
\text { - } & \text { Especialista em } \\
\text { Gerenciamento de } \\
\text { Projetos } \\
\text { - } \quad \text { Bacharel em Turismo e } \\
\text { Hotelaria } \\
\text { Bacharel em Educação } \\
\text { Física } \\
\end{array}$ \\
\hline Salete Valer & $\begin{array}{l}\text { Professora de Linguagem e } \\
\text { Comunicação }\end{array}$ & $\begin{array}{l}\text { - Bacharel em Letras, } \\
\text { Habilitação Secretariado } \\
\text { Executivo } \\
\text { - Licenciada em Letras- } \\
\text { Português } \\
\text { - Mestre em Linguística } \\
\text { - } \text { Doutora em } \\
\\
\text { Psicolingúistica Aplicada }\end{array}$ \\
\hline Silvana Graundenz Müller & $\begin{array}{l}\text { Professor de Produção de } \\
\text { Alimentos }\end{array}$ & $\begin{array}{ll}\text { - } & \text { Graduação em } \\
\text { - Tecnólogo em Hotelaria } \\
\text { Mestrado em } \\
\text { Engenharia de Produção } \\
\text { Doutorado em } \\
\text { Engenharia e Gestão do } \\
\text { Conhecimento } \\
\end{array}$ \\
\hline Uéslei Paterno & Professor de Libras & $\begin{array}{l}\text { - } \text { Graduação em } \\
\text { Ciencias Biológicas. } \\
\text { Especialização em } \\
\text { Educação Profissional } \\
\text { Inclusiva } \\
\text { Mestrado em Lingüística }\end{array}$ \\
\hline Vinícius de Lucca Filho & $\begin{array}{l}\text { Professor de Eventos e de } \\
\text { Gerenciamento de Receitas } \\
\text { (RM) }\end{array}$ & $\begin{array}{l}\text { - } \text { Bacharel em Turismo. } \\
\text { - } \text { Mestre em Tecnologia } \\
\text { - Doutora da Informação } \\
\text { - Douto em Geografia }\end{array}$ \\
\hline
\end{tabular}

A política institucional adotada pelo Campus que prevê capacitação a docentes que buscam elevação de titulação e baseia-se na Resolução nº 019/2012/CDP de maio de 2012, que aprova as normas para concessão de afastamento para pós-graduação aos servidores do IFSC.

6.2.1 Professores titulares por componente curricular

1Fase

\begin{tabular}{|l|c|l|}
\hline $\begin{array}{l}\text { COMPONENTE CURRICULAR - Introdução } \\
\text { ao Turismo e a Hotelaria }\end{array}$ & $\mathrm{CH}$ & \multicolumn{1}{|c|}{ PROFESSORES } \\
\hline Fundamentos do Turismo e da Hospitalidade & 72 & Fabíola Martins dos Santos \\
\hline Linguagem e Comunicação & 72 & Salete Valer \\
\hline Introdução à Administração Hoteleira & 72 & Tiago Savi Mondo \\
\hline Economia do Turismo & 72 & Vinícius de Lucca Filho \\
\hline
\end{tabular}

\begin{tabular}{|c|c|c|}
\hline Língua Espanhola Aplicada & 72 & Laura Lima \\
\hline TOTAL & 360 & \\
\hline \multicolumn{3}{|l|}{$2 \circ$ Fase } \\
\hline $\begin{array}{l}\text { COMPONENTE CURRICULAR } \\
\text { Operações na Hotelaria }\end{array}$ & $\mathrm{CH}$ & PROFESSORES \\
\hline Operação de Recepção e Reservas 1 & 72 & Tiago Savi Mondo \\
\hline Operação de Governança 1 & 72 & $\begin{array}{l}\text { Thianne Durand Mussoi de Freitas / } \\
\text { Fabíola M. dos Santos }\end{array}$ \\
\hline Segurança do Trabalho & 36 & Luciane Patrícia Oliari \\
\hline Língua Inglesa Aplicada 1 & 72 & Ângela Faria Brognoli \\
\hline Sustentabilidade na Hotelaria & 36 & Liz Cristina Camargo Ribas \\
\hline Estágio Obrigatório - Etapa 1 & 72 & $\begin{array}{l}\text { Fabíola Martins dos Santos/ Tiago Savi } \\
\text { Mondo/ Thianne Durand Mussoi }\end{array}$ \\
\hline TOTAL & 360 & \\
\hline
\end{tabular}

3 Fase
\begin{tabular}{|l|c|l|}
$\begin{array}{l}\text { COMPONENTE CURRICULAR } \\
\text { Operações na Hotelaria + Introdução a } \\
\text { Gestão Hoteleira }\end{array}$ & CH & \\
\hline Operação de Recepção e Reservas 2 & 36 & Tiago Savi Mondo \\
\hline Alimentos e Bebidas 1 & 72 & $\begin{array}{l}\text { Silvana Graudenz Müller / Débora Beron } \\
\text { Pinto }\end{array}$ \\
\hline Segurança dos Alimentos & 36 & Jane Parisenti/ Emilaura Alves \\
\hline Operação de Governança 2 & 36 & $\begin{array}{l}\text { Thianne Durand Mussoi de Freitas / } \\
\text { Fabíola M. dos Santos }\end{array}$ \\
\hline Gestão Financeira & 72 & Pedro José Raymundo \\
\hline Língua Inglesa Aplicada 2 & 72 & Ângela Faria Brognoli \\
\hline Gestão de Materiais & 36 & Tiago Savi Mondo \\
\hline TOTAL & 360 & \\
\hline
\end{tabular}

4ㅇ Fase

\begin{tabular}{|l|c|l|}
\hline $\begin{array}{l}\text { COMPONENTE CURRICULAR - Gestão } \\
\text { Hoteleira }\end{array}$ & $\mathrm{CH}$ & \multicolumn{1}{|c|}{ PROFESSORES } \\
\hline Controladoria & 72 & Larice Steffen Peters \\
\hline Alimentos e Bebidas 2 & 72 & $\begin{array}{l}\text { Silvana Graudenz Müller / Débora Beron } \\
\text { Pinto }\end{array}$ \\
\hline Gestão de Eventos na Hotelaria & 36 & Vinícius de Lucca Filho \\
\hline Gestão de Pessoas & 72 & Deosir Flávio Lobo de Castro Júnior \\
\hline Língua Inglesa Aplicada 3 & 72 & Ângela Faria Brognoli \\
\hline Sociedade e Trabalho & 36 & Fernando Goulart Rocha \\
\hline
\end{tabular}


ITOTAL

360

5o Fase

\begin{tabular}{|c|c|c|}
\hline $\begin{array}{l}\text { COMPONENTE CURRICULAR- Gestão e } \\
\text { Empreendedorismo }\end{array}$ & $\mathrm{CH}$ & PROFESSORES \\
\hline Marketing Hoteleiro & 72 & Deosir Flávio Lobo de Castro Júnior \\
\hline Gestão da Qualidade e Inovação & 72 & Tiago Savi Mondo \\
\hline Tópicos Especiais & 36 & Fabíola Martins dos Santos \\
\hline Metodologia da Pesquisa (Pré TCC) & 36 & Luciano de Azambuja / Tiago Savi Mondo \\
\hline Estatística Aplicada à Hotelaria & 36 & Pedro José Raymundo \\
\hline Empreendedorismo e Plano de Negócio & 72 & Larice Steffen Peters \\
\hline $\begin{array}{l}\text { Gerenciamento das Receitas (Revenue } \\
\text { Management) }\end{array}$ & 36 & Vinícius de Lucca Filho \\
\hline TOTAL & 360 & \\
\hline
\end{tabular}

6ㅇ Fase

\begin{tabular}{|l|c|l|}
\hline $\begin{array}{l}\text { COMPONENTE CURRICULAR- Estágio e } \\
\text { TCC }\end{array}$ & CH & \multicolumn{1}{|c|}{ PROFESSORES } \\
\cline { 1 - 1 } $\begin{array}{l}\text { Estágio Obrigatório Supervisionado - Etapa } \\
2\end{array}$ & 300 & $\begin{array}{l}\text { Fabíola Martins dos Santos/ Tiago Savi } \\
\text { Mondo/ Thianne Durand Mussoi }\end{array}$ \\
\hline Trabalho de Conclusão de Curso - TCC & 100 & Todos os professores do quadro \\
\hline
\end{tabular}

COMPONENTE CURRICULAR OPTATIVO

\begin{tabular}{|l|c|c|}
\hline COMPONENTE CURRICULAR & $\mathrm{CH}$ & PROFESSORES \\
\hline Libras & 72 & Uéslei Paterno \\
\hline
\end{tabular}

\subsection{Corpo Administrativo}

Todos os técnico-administrativos abaixo citados têm regime de trabalho de 40horas/semanais.

\begin{tabular}{|c|c|c|}
\hline Nome & Cargo & Titulação \\
\hline \multirow{2}{*}{ André Dalla Possa } & \multirow{2}{*}{ Assistente Administrativo } & Graduação Comunicação Social \\
\hline & & Mestrado em Sociologia \\
\hline \multirow{2}{*}{ Bruna de Araújo Dechen } & \multirow{2}{*}{ Assistente Administrativo } & Bacharel em Administração \\
\hline & & Bacharel Relações Internacionais \\
\hline \multirow{2}{*}{ Camila Paim Veran } & \multirow{2}{*}{ Assistente Administrativo } & Bacharel em Hotelaria \\
\hline & & Espec. Educação Profissional \\
\hline Carme Rita Borella & Assistente Administrativo & $\begin{array}{l}\text { Tecnólogo em Eletrônica } \\
\text { Especialização Métodos de Melhoria da } \\
\text { Produtividade }\end{array}$ \\
\hline
\end{tabular}

\begin{tabular}{|c|c|c|}
\hline Nome & Cargo & Titulação \\
\hline $\begin{array}{l}\text { Caroline Daufemback } \\
\text { Henrique }\end{array}$ & Técnica em Audiovisuais & Designer \\
\hline \multirow{2}{*}{ Cristiane Correa Paulick } & \multirow{2}{*}{ Assistente Administrativo } & Técnica em Eletrotécnica \\
\hline & & Bacharel e Licenciada em História \\
\hline Danielli Prado Dzioba Loss & Técnica em Laboratório & Técnico em Nutrição e Dietética \\
\hline Elizabethe Costa França & Pedagoga & $\begin{array}{l}\text { Licenciado em Pedagogia } \\
\text { Especialização em Gestão e } \\
\text { Metodologia do Ensino }\end{array}$ \\
\hline $\begin{array}{l}\text { Fernando Maciel de } \\
\text { Miranda }\end{array}$ & $\begin{array}{l}\text { Técnico de Tecnologia de } \\
\text { Informação }\end{array}$ & $\begin{array}{l}\text { Graduação em Administração } \\
\text { Especialização em Rede de } \\
\text { computadores }\end{array}$ \\
\hline Giuliana F. De Santis & Técnica em Laboratório & $\begin{array}{l}\text { Técnico em Nutrição } \\
\text { Curso de Aperfeiçoamento em Nutrição }\end{array}$ \\
\hline $\begin{array}{l}\text { Gleicy Corrêa Nunes } \\
\text { Marques }\end{array}$ & Assistente Administrativo & $\begin{array}{l}\text { Técnica em Eletrotécnica } \\
\text { Superior de Tecnologia em } \\
\text { Administração Pública }\end{array}$ \\
\hline Igor Fernandes Kattar & Analista de TI & Ciências da Computação \\
\hline Ivanir Ribeiro & Psicóloga & $\begin{array}{l}\text { Graduação em Psicologia } \\
\text { Especialização na Área da Violência } \\
\text { Doméstica } \\
\text { Mestrado em Educação }\end{array}$ \\
\hline Jardel Alzemiro Vieira & Técnico de Laboratório & Técnico em Mecânica \\
\hline João Paulo Nunes da Silva & Assistente Administrativo & \begin{tabular}{|l} 
Biologia \\
Especialização em Administração
\end{tabular} \\
\hline $\begin{array}{l}\text { Jorge Augusto Sandoval } \\
\text { Ferreira }\end{array}$ & Assistente Administrativo & Graduação em Administração \\
\hline \multirow{2}{*}{ José Eduardo Izzo Júnior } & \multirow{2}{*}{ Assistente Administrativo } & Graduação em Direito \\
\hline & & Especialista em Direito Constitucional \\
\hline \multirow{2}{*}{ Josiane Agustini } & \multirow{2}{*}{ Assistente Social } & Bacharel em Serviço Social \\
\hline & & Mestre em Serviço Social \\
\hline Juliana Farias de Lima & Assistente Administrativo & $\begin{array}{l}\text { Técnica em Meio Ambiente } \\
\text { Graduação em Geografia }\end{array}$ \\
\hline $\begin{array}{l}\text { Kênia Raupp Coutinho } \\
\text { Koch }\end{array}$ & Bibliotecária & $\begin{array}{l}\text { Bacharel em Biblioteconomia } \\
\text { Especialização em Gestão de } \\
\text { Informação }\end{array}$ \\
\hline Letícia Aparecida Martins & Pedagoga & $\begin{array}{l}\text { Licenciada em Pedagogia } \\
\text { Especialista em Gestão Pública } \\
\text { Mestre em Educação }\end{array}$ \\
\hline Luis Eduardo Lyra & Assistente Administrativo & \begin{tabular}{|l} 
Graduação em Engenharia Mecânica \\
Especialização Gestão de Pessoas
\end{tabular} \\
\hline $\begin{array}{l}\text { Luiz Cláudio Soufen } \\
\text { Tumolo }\end{array}$ & Assistente Administrativo & $\begin{array}{l}\text { Bacharel em Análise de Sistemas } \\
\text { Especialização em Administração } \\
\text { Empresas para Executivos }\end{array}$ \\
\hline Luiz Felipe Lindenberg & Assistente Administrativo & Técnico em Segurança do Trabalho \\
\hline \multirow[b]{2}{*}{ Márcia Coghetto Piva } & \multirow[b]{2}{*}{ Assistente Administrativo } & Licenciatura Pedagoga \\
\hline & & \begin{tabular}{|l} 
Bacharel em Direito \\
Especialização em Psicoterapia
\end{tabular} \\
\hline
\end{tabular}




\begin{tabular}{|c|c|c|}
\hline Nome & Cargo & Titulação \\
\hline \multirow{3}{*}{ Meimilany Gelsleichter } & \multirow{3}{*}{ Pedagoga } & Licenciada em Pedagogia \\
\hline & & Bacharel Relações Internacionais \\
\hline & & Especialista Gestão Escolar EJA \\
\hline Milton Makono Toyokawa & Assistente Administrativo & Não possui \\
\hline \multirow{2}{*}{ Morgana Dias Johan } & \multirow{2}{*}{$\begin{array}{l}\text { Técnico em Assuntos } \\
\text { Educacionais }\end{array}$} & Licenciatura em Pedagogia \\
\hline & & Especialização em Educação \\
\hline \multirow[t]{2}{*}{ Nelda Plentz de Oliveira } & \multirow[t]{2}{*}{ Pedagoga } & $\begin{array}{l}\text { Licenciada em Pedagogia } \\
\text { Especialista em Metodologia do Ensino } \\
\text { Tecnológico }\end{array}$ \\
\hline & & Mestre em Educação \\
\hline Patrícia da Silva & Bibliotecária & $\begin{array}{l}\text { Bacharel em Biblioteconomia } \\
\text { Especialista em Educação, Currículo e } \\
\text { Cultura }\end{array}$ \\
\hline \multirow{2}{*}{ Paula Bitencourt Neto } & \multirow{2}{*}{ Técnico de Laboratório } & Bacharel em Administração \\
\hline & & Técnica em Cozinha \\
\hline Raquel Franscisco Mafra & Assistente Administrativo & $\begin{array}{l}\text { Licenciatura em Geografia (em } \\
\text { andamento) }\end{array}$ \\
\hline Ricardo Genésio Silvano & Auxiliar Administrtivo & não possui \\
\hline \multirow{3}{*}{ Rosana Kimmel Rodrigues } & \multirow{3}{*}{$\begin{array}{l}\text { Técnico em } \\
\text { Contabilidade }\end{array}$} & Técnico em Contabilidade \\
\hline & & Graduação em Gestão Pública. \\
\hline & & Especialização em Gestão de Pessoas \\
\hline \multirow{2}{*}{ Rosângela Pieczarka } & \multirow{2}{*}{ Assistente Administrativo } & $\begin{array}{l}\text { Graduada em educação Física e } \\
\text { Fisioterapia. }\end{array}$ \\
\hline & & $\begin{array}{l}\text { Especialização em Prevenção e } \\
\text { Reabilitação Física }\end{array}$ \\
\hline Ruben Moret Pardo Lima & Engenheiro & $\begin{array}{l}\text { Graduação em Engenharia Civil } \\
\text { Especialização em Engenharia e } \\
\text { Segurança no Trab }\end{array}$ \\
\hline \multirow{2}{*}{ Taciany Passos Medeiros } & \multirow{2}{*}{ Técnico de Laboratório } & Técnico em Nutrição e Dietética \\
\hline & & Bacharel em Administração \\
\hline Valéria Aparecida Godoy & Técnico de Laboratório & Bacharel em Ciências dos Alimentos \\
\hline \multirow{2}{*}{ Valéria Matilde dos Santos } & \multirow{2}{*}{ Contadora } & Bacharel em Ciências Contábeis \\
\hline & & Especialização em Gestão Pública \\
\hline \multirow{2}{*}{ Sandra Fátima Lorenzi } & \multirow{2}{*}{ Auxiliar Administrtivo } & Graduada Farmácia \\
\hline & & Especialização Gestão de Pessoas \\
\hline \multirow{2}{*}{ Vanessa Junckes } & \multirow{2}{*}{ Técnica em Laboratório } & Técnica em Nutrição e Dietética \\
\hline & & Graduação em Processos Gerenciais \\
\hline \multirow{2}{*}{$\begin{array}{l}\text { Vanessa Livramento } \\
\text { Garcia }\end{array}$} & \multirow{2}{*}{ Administrador } & Bacharel em Administração. \\
\hline & & Mestre em Administração \\
\hline
\end{tabular}

\subsection{Núcleo Docente Estruturante}

O Colegiado do Curso Superior de Tecnologia em Hotelaria, do Campus Florianópolis Continente do Instituto Federal de Educação, Ciência e Tecnologia de Santa Catarina - IFSC, no uso das suas atribuições regimentais, considerando o disposto na Resolução № 01 de 17 de junho de 2010 da Comissão Nacional de Avaliação da Educação Superior -CONAES que normatiza o Núcleo Docente Estruturante (NDE) em regimento específico.
São atribuições do NDE: contribuir para consolidação do perfil profissional do egresso do curso; zelar pela integração curricular interdisciplinar entre as diferentes atividades de ensino constantes no currículo; indicar formas de incentivo ao desenvolvimento de linhas de pesquisa e extansão, no cundas de necessidades da Graduacão, de exigências do mercado de trabalho e afinadas com oriundáticas públicas relativa à área de as pollicas públicas relativas à área de conhecin Dedrizes Cún do apreciação do Colegiado do Curso.

São atribuições dos membros do NDE: atuar no desenvolvimento do curso, apresentando liderança acadêmica, percebida na produção de conhecimentos na área de Hotelaria, no desenvolvimento do ensino, da pesquisa e da extensão e em outras dimensões consideradas importantes pela Instituição.

O NDE será constituído pela Coordenação do Curso; com mandato de dois anos, permitida a recondução, enquanto se mantiver na função de Coordenador e por quatro membros representantes docentes do curso, sendo todos com titulação acadêmica obtida em programas de pós-graduação stricto sensu.

O NDE é o responsável pela concepção, acompanhamento, consolidação e avaliação do PPC e será composto pelos seguintes docentes:

\begin{tabular}{|c|c|c|c|}
\hline Nome & $\begin{array}{c}\text { Regime de } \\
\text { trabalho }\end{array}$ & $\begin{array}{l}\text { Carga horária } \\
\text { Atividade NDE }\end{array}$ & Titulação \\
\hline Fabíola Martins dos Santos & $40 \mathrm{~h}(\mathrm{DE})$ & $\begin{array}{l}25 \mathrm{~h} / \text { semanal } \\
\text { Coordenação }\end{array}$ & $\begin{array}{l}\text { Doutora em Geografia } \\
\text { Mestre em Turismo e } \\
\text { Hotelaria } \\
\text { Especialista em Marketing } \\
\text { para Gestão Empresarial } \\
\text { Especialista em } \\
\text { Planejamento e Gestão } \\
\text { Hoteleira } \\
\text { Bacharel em Turismo e } \\
\text { Hotelaria }\end{array}$ \\
\hline Vinicius De Lucca Fllho & $40 \mathrm{~h}(\mathrm{DE})$ & $2 \mathrm{~h} / \mathrm{semanal}$ & $\begin{array}{l}\text { Doutor em Geografia } \\
\text { Mestre em Ciência da } \\
\text { Informação, Bacharel em } \\
\text { Turismo }\end{array}$ \\
\hline Tiago Savi Mondo & $40 \mathrm{~h}$ (DE) & $2 \mathrm{~h} / \mathrm{semanal}$ & $\begin{array}{l}\text { Doutor em Administração } \\
\text { Mestre em Administração } \\
\text { Especialista em } \\
\text { Gerenciamento de Projetos } \\
\text { Bacharel em Turismo e } \\
\text { Hotelaria } \\
\text { Bacharel em Educação } \\
\text { Física }\end{array}$ \\
\hline $\begin{array}{c}\text { Thianne Durand Mussoi de } \\
\text { Freitas }\end{array}$ & $40 \mathrm{~h}(\mathrm{DE})$ & $2 \mathrm{~h} /$ semanal & $\begin{array}{l}\text { Mestre em Turismo e } \\
\text { Hotelaria, Bacharel em } \\
\text { Turismo e Hotelaria }\end{array}$ \\
\hline Pedro Raymundo & $40 \mathrm{~h}(\mathrm{DE})$ & $2 \mathrm{~h} / \mathrm{semanal}$ & $\begin{array}{l}\text { Mestre em Engenharia de } \\
\text { Produção. } \\
\text { Bacharel em Administração }\end{array}$ \\
\hline
\end{tabular}




\subsection{Colegiado do Curso}

O Colegiado de Curso Superior de Tecnologia em Hotelaria do Instituto Federal de Educação, Ciência e Tecnologia de Santa Catarina, Campus Florianópolis Continente (IFSC-CFC) é um órgão consultivo, com composição, competências e funcionamento definidos em seu Regimento Interno. Em consonância com a Deliberação do CEPE/IFSC № 004, de 05 de abril de 2010 que regulamenta os Colegiados de Curso de Graduação do Instituto Federal de Educação Ciência e Tecnologia de Santa Catarina, compete ao Colegiado do Curso Superior de Tecnologia em Totelaria: analisar, avaliar e propor alterações ao Projeto Pedagógico do Curso; acompanhar o Hotelaria: analisar, avaliar e propor alterações ao Projeto Pedagógico do Curso; acompanhar o
processo de reestruturação curricular; propor e/ou validar a realização de atividades processo de reestruturação curricular; propor e/ou validar a realização de atividades complementares do Curso; acompanhar os processos de avaliaçăo do Curso; acompanhar os trabalhos e dar suporte ao Núcleo Docente Estruturante; decidir, em primeira instância, recursos referentes à matrícula, à validação de Unidades Curriculares e à transferência de curso ou turno; acompanhar o cumprimento de suas decisões; propor alterações no Regimento do Colegiado do Curso; exercer as atribuições conferidas pela legislação em vigor.

São ainda atribuições do Colegiado do Curso: estabelecer o perfil profissional e a proposta pedagógica do Curso; elaborar o seu Regimento Interno; analisar e avaliar o curriculo do Curso suas alterações; fixar o turno de funcionamento do Curso; deliberar sobre os pedidos de prorrogação de prazos para Trabalhos de Conclusão de Curso; emitir parecer sobre processos de revalidação de diplomas de Cursos de Graduação, expedidos por estabelecimentos estrangeiros de ensino superior; deliberar, em grau de recurso, sobre decisões do(a) Presidente(a) do Colegiado do Curso;
7. INFRAESTRUTURA FÍSICA

7.1 Instalações gerais e equipamentos

\begin{tabular}{|c|c|}
\hline AMBIENTE & METRAGEM \\
\hline $\begin{array}{c}\text { Departamento de Desenvolvimento de Ensino e } \\
\text { Extensão }\end{array}$ & $51,75 \mathrm{~m}^{2}$ \\
\hline Sala da Direção / & $51,75 \mathrm{~m}^{2}$ \\
\hline
\end{tabular}

O espaço do Departamento de Ensino e Extensão possui janelas para adequada ventilação iluminação natural. A iluminação artificial é composta por luzes frias. A chefia de ensino coordenações de curso possuem gabinetes próprios equipados com computadores.

\subsection{Sala de professores e salas de reuniões}

\begin{tabular}{|c|c|}
\hline AMBIENTE & METRAGEM \\
\hline Sala dos Docentes & $51,75 \mathrm{~m}^{2}$ \\
\hline
\end{tabular}

espaço para os docentes possui 18 bancadas próprias de trabalho com 6 computadores, a condicionado, armários individuais, equipamento fotocopiadora e mesa redonda para conversa em grupo. O espaço possui janelas para adequada ventilação e iluminação natural. A iluminação artificial é composta por luzes frias.

7.3 Salas de aula
\begin{tabular}{|l|l|l|}
\hline Ambiente & Metragem & Equipamentos \\
\hline Sala de Aula & $51,75 \mathrm{~m}^{2}$ & $\begin{array}{l}\text { Projetor multimídia, microcomputador com acesso à } \\
\text { internet, caixas de som, quadro branco, mobiliário } \\
\text { escolar. }\end{array}$ \\
\hline
\end{tabular}

O Campus Florianópolis-Continente possui 7 salas de aula compostas com os equipamentos listados no quadro acima.

7.4 Polos de apoio presencial, se for o caso, ou estrutura multicampi (para cursos EAD) Não se aplica.

\subsection{Sala de tutoria (para cursos EAD)}

Não se aplica.

7.6 Suportes midiáticos (para cursos EAD)

Não se aplica.

\subsection{Biblioteca}

7.7.1 Instalações/espaço físico

A biblioteca está atualmente estruturada em $79 \mathrm{~m}^{2}$ e possui acervo bibliográfico específico. O ambiente é bem ventilado, possui 3 computadores para consulta do acervo, assim como mesas coletivas para estudo.

Está prevista a alteração física da estrutura da biblioteca compreendendo $298 \mathrm{~m}^{2}$, contendo sala

de estudos individuais, sala para trabalhos em grupo, guarda volumes e sala de multimeios. 
7.7.2 Equipamentos

A biblioteca conta atualmente com três computadores para pesquisa e consulta ao acervo, com acesso aos alunos, quatro computadores para o setor administrativo da biblioteca, uma impressora scanner e dois leitores de código de barras.

\subsubsection{Mobília}

A biblioteca conta atualmente conta com mesas de estudo, estantes com todo acervo da biblioteca e estações de trabalho para equipe.

\subsubsection{Acervo bibliográfico}

As obras listadas nos componentes curriculares que se referem às bibliografias básica complementar fazem parte do acervo bibliográfico do Campus e estão listadas neste projeto no item 5.7 que se refere aos Componentes Curriculares. A escola disponibiliza acesso ao site "Direct Science" possibilitando ao aluno e aos professores consulta a artigos científicos, bem como revistas especializadas na área.

7.7.5 Acesso dos alunos e equipamentos informática

O laboratório de Reservas e Idiomas é equipado com software de gerenciamento hoteleiro e de idiomas, ferramentas que contribuem para o processo de ensino e aprendizagem.

O curso Superior de Tecnologia e Hotelaria utilizará também o Laboratório de Informática nas atividades de sala de aula para pesquisa na internet. A utilização pelos alunos dos Laboratórios utilizada com a supervisão do professor.

\begin{tabular}{|c|c|c|}
\hline $\begin{array}{l}\text { Identificação do Espaço: Laboratório de } \\
\text { informática e Laboratório de Idiomas } \\
\text { Área de atuação: Turismo e Hospitalidade } \\
\end{array}$ & \multicolumn{2}{|c|}{$\begin{array}{l}\text { Qtde. de postos de trabalho: } 24 \text { Lab. Infor. + } \\
\text { 21 lab. Idiomas = totalizando } 45 \\
\text { Área construída: } 51,45 m^{2}\end{array}$} \\
\hline & 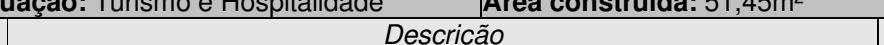 & \\
\hline 1 & $\begin{array}{l}\text { PLACA PRINCIPAL } \\
\text { 1. Arquitetura ATX ou BTX, conforme padrões estabelecidos e } \\
\text { divulgados no site www.formfactors.org, organismo que define os } \\
\text { padrões existentes; } \\
\text { 2. } 4 \text { (quatro) slots para memória tipo DDR3, permitindo a instalação de } \\
\text { até } 16 \text { (dezesseis) Gigabytes com barramento } 1600 \mathrm{MHz} \text {; } \\
\text { 3. Deverá possuir no mínimo } 2 \text { (dois) slots livres tipo PCI-E, sendo } 1 \\
\text { (um) do tipo PCI Express } 16 x \text {. Caso a controladora de vídeo seja do tipo } \\
\text { off-board, está deverá ser obrigatoriamente do tipo PCI-Express 16X. } \\
\text { Nesta hipótese o equipamento deverá possuir } 1 \text { (uma) interface PCI-E } \\
\text { livre. } \\
\text { 4. Sistema de detecção de intrusão de chassis, com acionador instalado } \\
\text { no gabinete que permita a deteç̧ão de abertura ainda que o } \\
\text { equipamento esteja desligado, mas conectado a fonte de energia; } \\
\text { 5. Chip de segurança TPM (Trusted Platform Module), versão 1.2, } \\
\text { soldado à placa principal, acompanhado de drivers e software para } \\
\text { utilização do chip; } \\
\text { 6. Controladora SATA } 3 \text { ou versão superior, integrada e compatível com } \\
\text { os periféricos adiante especificados; } \\
\text { 7. Regulagem da velocidade de rotação do cooler da CPU de forma } \\
\text { automática, de acordo com a variação de temperatura da CPU; } \\
\text { 8. Ser do mesmo fabricante do equipamento ou projetada } \\
\text { especificamente para o equipamento, não sendo aceitas placas de livre } \\
\text { comercialização no mercado. A comprovação de desenvolvimento } \\
\text { exclusivo para o projeto deverá ser feita por meio de declaração }\end{array}$ & \\
\hline
\end{tabular}

Identificação do Espaço: Laboratório de Qtde. de postos de trabalho: $24 \mathrm{~L}$ informática e Laboratório de Idiomas 21 lab. Idiomas = totalizando 45 fornecida pelo fabricante da placa principal, dispensável no outro caso; 9. Suportar boot por pendrive ou disco conectado a uma porta USB 2.0 BIOS

1. Unified Extensible Firmware Interface - Tipo Flash Memory, utilizando memória não volátil e reprogramável, e compatível com os padrões ACPI 2.0 e Plug-and-Play;

2. Lançada a partir de 2011 e entregue na versão mais atual disponibilizada pelo fabricante;

3. Possuir senhas de Setup para Power On, Administrador e Disco rígido;

4. Permitir a inserção de código de identificação do equipamento dentro da própria BIOS (número do patrimônio e número de série).

5. Serão aceitas BIOS com reprogramação via software desde que estes estejam devidamente licenciados para o equipamento e constantes no CD-ROM/DVD-ROM de drivers e aplicativos que deverá vir junto com o equipamento e também disponibilizados para download no sítio do fabricante;

6. Suporte à tecnologia de previsão/ contingenciamento de falhas de disco rígido S.M.A.R.T habilitada;

7. Deve ser do mesmo fabricante do equipamento ou desenvolvida especificamente para o projeto. A comprovação do desenvolvimento exclusivo para o projeto deverá ser feita por meio de decl fornecida pelo fabricante da BIOS, dispensável no outro caso.

8. Deverá possibilitar replicação de configuração de BIOS

PROCESSADOR -

1. Arquitetura 64 bits; clock real de, no mínimo, $3.2 \mathrm{GHz}$, com 4 núcleos físicos;

\section{MEMÓRIA RAM}

1. Memória RAM tipo DDR3-1600 MHz ou superior, com no mínimo (quatro) Gigabytes

2. Os módulos de memória devem ser homologados pelo fabricante devem ser idênticos em marca/modelo para cada computador fornecido.

\section{CONTROLADORA DE VÍDEO}

1. Controladora de Vídeo integrada com capacidade de alocação dinâmica de até $1.7 \mathrm{~GB}$ de memória de vídeo OU Placa de Vídeo offboard PCl-e x16 com no mínimo 1GB de memória;

2. Tanto a controladora de vídeo quanto a placa off-board deverão ter a capacidade para controlar 02 (dois) monitores simultaneamente permitir a extensão da área de trabalho;

3. Deverá possuir compatibilidade com a tecnologia DirectX 11 .

4. Taxa de atualização de $60 \mathrm{~Hz}$ ou superior;

5. Deverá possuir, no mínimo, uma conexão de vídeo digital (display port ou DVI);

\section{INTERFACES}

1. Controladora de Rede integrada à placa mãe com velocidade de 100/1000 Mbps, padrões Ethernet, Fast-Ethernet e Gigabit Ethernet autosense, full-duplex, plug-and-play, configurável totalmente por autosense, full-duplex, plug-and-play, configuravel totalmente por
software, com conector padrão RJ-45 e função wake-on-lan em funcionamento e suporte a múltiplas VLANS (802.1q e 802.1x). Não 


\section{Identificação do Espaço: Laboratório de}

informática e Laboratório de Idiomas

Qtde. de postos de trabalho:
21 lab. Idiomas $=$ totalizando 45

esquerdo, direito e central próprio para rolagem;

2. Resolução mínima de 800 (oitocentos) dpi ou superior, conector USB 2.0 ou superior;

3. Mouse com fio, sem o uso de adaptadores;

4. Deve possuir impressa a logomarca do fabricante do microcomputador, ainda que seja de fornecedor (montador) distinto.

OUTROS REQUISITOS

1. Todos os equipamentos ofertados (gabinete, teclado, mouse monitor) devem possuir gradações neutras das cores preta ou cinza, manter o mesmo padrão de cor predominante do gabinete;

2. Deverá ser apresentado prospecto com as características técnicas de todos os componentes do equipamento, como placa principal processador, memória, interface de rede, fonte de alimentação, disco rígido, unidade leitora de mídia óptica, mouse, teclado e vídeo, incluindo especificação de marca, modelo, e outros elementos que de forma inequívoca identifiquem e comprovem as configurações cotadas, possíveis expansões e upgrades, através de certificados, manuais técnicos, folders e demais literaturas técnicas editadas pelos fabricantes. Serão aceitas cópias das especificações obtidas em sítio dos fabricantes na Internet, em que constem o respectivo endereco eletrônico. A escolha do material a ser utilizado fica a critério do proponente;

proponente; 3. Todos os equipamentos a serem entregues deverão ser idênticos, ou seja, todos os componentes externos e internos de mesmos modelos marcas dos utilizados nos equipamentos enviados para avaliação e/ou homologação. Caso o componente não mais se encontre disponivel no mercado, admitem-se substiutos com idênticas ou superiores, mediante nov

homologação;

4. Todos os cabos e conectores necessários ao funcionamento dos equipamentos deverão ser fornecidos, com comprimento de, no mínimo $1,5 \mathrm{~m}$ (um metro de cinquenta centímetros). Cabos de conexão à red elétrica deverão seguir o padrão NBR-14136;

5. As unidades do equipamento deverão ser entregues devidamente acondicionadas em embalagens individuais adequadas, que utilizem preferencialmente materiais recicláveis, de forma a garantir a máxim proteção durante o transporte e a armazenagem;

6. Nenhum dos equipamentos fornecidos poderá conter substâncias perigosas como mercúrio $(\mathrm{Hg})$, chumbo $(\mathrm{Pb})$, cromo hexavalente $(\mathrm{Cr}(\mathrm{VI}))$, cádmio $(\mathrm{Cd})$, bifenil polibromados (PBBs), éteres difenilpolibromados (PBDEs) em concentração acima da recomendada na diretiva RoHS (Restriction of Certain Hazardous Substances), sendo que para efeitos de avaliação das amostras e aceitação do produto deverá ser fornecido certificacão emitida por instituicão credenciada pelo INMETRO, sendo aceito ainda, a comprovação deste requisito por intermédio da sertificaça explicitamente tal informação;

\section{GARANTIA E SERVIÇOS}

1. A garantia de funcionamento será pelo período de 48 (quarenta oito) meses, contada a partir do recebimento definitivo do equipamento, sem prejuízo de qualquer política de garantia adicional oferecida pelo

\begin{tabular}{|c|c|c|}
\hline $\begin{array}{l}\text { Identificação do Espaço: Laboratório de } \\
\text { informática e Laboratório de Idiomas }\end{array}$ & \multicolumn{2}{|c|}{$\begin{array}{l}\text { Qtde. de postos de trabalho: } 24 \text { Lab. Infor. + } \\
21 \text { lab. Idiomas = totalizando } 45\end{array}$} \\
\hline & $\begin{array}{l}\text { fabricante; } \\
\text { 2. O serviço de garantia será exigido da empresa (licitante) vencedora. } \\
\text { Caberá a mesma prover o serviço de garantia, seja através de sua } \\
\text { equipe de helpdesk, da fabricante ou rede autorizada pela mesma. } \\
\text { 3. O IFSC remeterá a empresa (licitante) vencedora a lista de } \\
\text { equipamentos que apresentarem defeito, dentro do período de garantia, } \\
\text { acompanhado do Número de Série de cada equipamento e a descrição } \\
\text { do defeito, cabendo a esta empresa dar encaminhamento a solicitação. } \\
\text { Não será aceito nenhum outro meio para a solicitação deste serviço de } \\
\text { garantia. } \\
\text { 4. A empresa vencedora deverá fornecer endereço de e-mail, número } \\
\text { de telefone e nome do funcionário responsável por receber as } \\
\text { solicitações de serviço de garantia do IFSC. A partir do momento em } \\
\text { que for aberto o chamado, via telefone ou mensagem eletrônica (e- } \\
\text { mail), com os serviços solicitados, a empresa (licitante) vencedora terá } \\
\text { o3 (três) dias úteis para atender ao chamado. O não atendimento ao } \\
\text { chamado no prazo estipulado acarretará as penalidades contidas neste } \\
\text { edital. } \\
\text { 5. Caso a licitante vencedora não seja fabricante dos equipamentos da } \\
\text { marca/modelo ofertado, deverá apresentar documento de } \\
\text { credenciamento junto ao Fabricante do equipamento. } \\
\text { 6. Atendimento no local (on site) para o conjunto Gabinete e Monitor; } \\
\text { 7. Comprovação que o modelo ofertado é da linha corporativa. }\end{array}$ & \\
\hline 2 & $\begin{array}{l}\text { MONITOR DE VÍDEO (Laboratório de Idiomas) } \\
\text { 1. Tela 100\% plana de LED, tamanho mínimo de } 18,5 \text { ", } 16.7 \text { Milhões de } \\
\text { cores; } \\
\text { 2. Resolução mínima de } 1280 \times 1024 \text { ou } 1920 \text { x } 1080 \text { pixels para cada } \\
\text { monitor que a placa suporte; } \\
\text { 3. Conectores de Entrada: } 01 \text { (uma) entrada VGA e } 01 \text { (uma) entrada } \\
\text { DVI ou DisplayPort; Não serão aceitos adaptadores. } \\
\text { 4. Deverá ser entregue um cabo VGA, } 01 \text { cabo de conexão DVI ou } \\
\text { Displayport e um cabo de alimentação; } \\
\text { 5. Certificação EPEAT no mínimo na categoria Gold comprovada } \\
\text { através do site http://www.epeat.net; } \\
\text { 6. Controle digital de brilho e contraste; } \\
\text { 7. O equipamento deverá apresentar compatibilidade eletromagnética e } \\
\text { de radiofrequência IEC } 61000 \text { comprovado através de certificado ou } \\
\text { relatório de avaliação de conformidade emitido por órgão credenciado } \\
\text { pelo INMETRO; } \\
\text { 8. Tela antirreflexiva. Não sendo aceita a solução glare (brilhante ou } \\
\text { polida) ou adesivos } \\
\text { antirreflexivos; } \\
\text { 9. Fonte de Alimentação interna para corrente alternada com tensões } \\
\text { de entrada de } 100 \text { a } 240 \text { VAC (+/-10\%) com ajuste automático, } \\
\text { frequência } 50-60 H z ; \\
\text { 10. Os monitores poderão ser de outros fabricantes, fornecidos em } \\
\text { regime de OEM, com a presença da logomarca da empresa fabricante } \\
\text { do equipamento (gabinete), desde que devidamente comprovado pelo } \\
\text { fabricante (declaração do fabricante); } \\
\text { 11. Os fornecedores (licitantes) deverão prestar as garantias dos } \\
\text { monitores de vídeo nos mesmos prazos estipulados para a estação de } \\
\text { trabalho propriamente dita, devendo ser ratificada na proposta }\end{array}$ & \\
\hline
\end{tabular}




\begin{tabular}{|c|c|c|}
\hline \multicolumn{3}{|c|}{$\begin{array}{l}\text { Identificação do Espaço: Laboratório de } \\
\text { informática e Laboratório de Idiomas }\end{array}$} \\
\hline & $\begin{array}{l}\text { comercial, como condição de aprovação das amostras e da } \\
\text { adjudicação. } \\
\text { 12. O equipamento deverá apresentar compatibilidade eletromagnética } \\
\text { e de radiofrequência IEC } 61000 ;\end{array}$ & \\
\hline 3 & 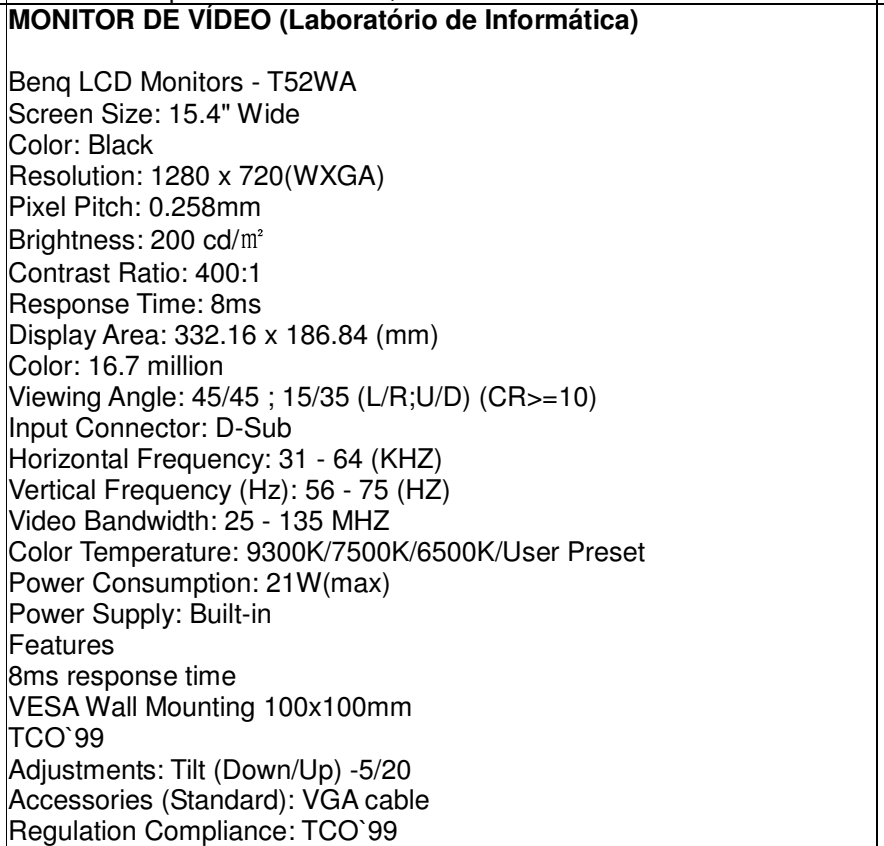 & \\
\hline \multirow{11}{*}{4} & Projetor Epson PowerLite W8+ & \\
\hline & Características & \\
\hline & $\begin{array}{l}2500 \text { ANSI Lumens Resolução WXGA (1280 x 800) - Widescreen } \\
\text { Contraste } 2000: 1 \text { Entrada HDMI (compatível com 1080p - Full HD) } \\
\text { Entrada USB para vídeo Entrada USB para Pendrive (Slideshow) Peso } \\
\text { de } 2,3 \mathrm{Kg} \text { Liga e Desliga Instantaneamente Senha e Barra de } \\
\text { Segurança A/N Mute Entrada de video composto, S-vídeo e video } \\
\text { componente. Entrada para computador (VGA) }\end{array}$ & \\
\hline & Brilho/lúmens-> 2.500 ANSI Lumens & \\
\hline & Resolução nat. -> WXGA 1280x800 Pixels & \\
\hline & Conectividade & \\
\hline & Audio in: RCA $\times 1$ & \\
\hline & USB Tipo A & \\
\hline & USB tipo B & \\
\hline & Computador VGA (Mini D-sub 15 pin) $\times 1$ & \\
\hline & HDMI & \\
\hline
\end{tabular}

\begin{tabular}{|c|c|c|}
\hline $\begin{array}{l}\text { Identificação do Espaço: Laboratório de } \\
\text { informática e Laboratório de Idiomas }\end{array}$ & \multicolumn{2}{|c|}{$\begin{array}{l}\text { Qtde. de postos de trabalho: } 24 \text { Lab. Infor. + } \\
21 \text { lab. Idiomas = totalizando } 45\end{array}$} \\
\hline & 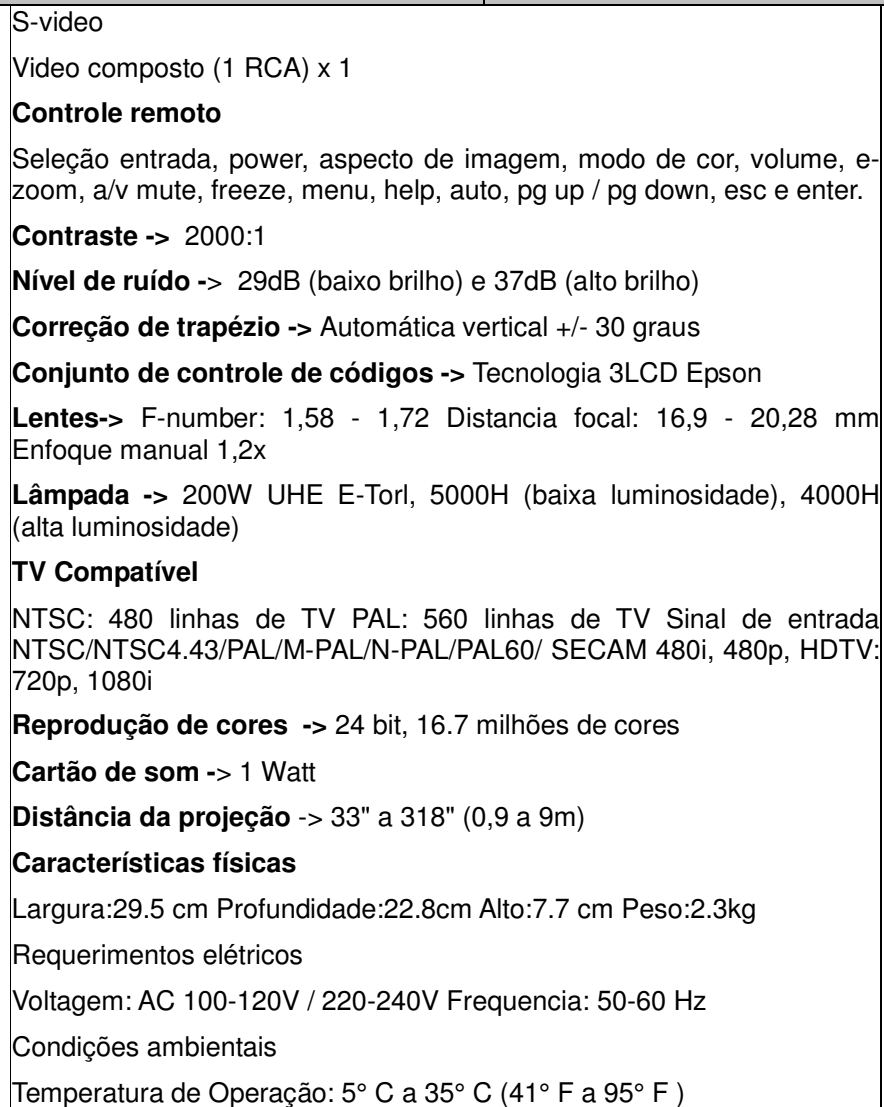 & \\
\hline 5 & $\begin{array}{l}\text { Notebook com processador Intel Celeron M (Tecnologia Centrino), com } \\
1,58 \text { giga de memória Ram de } 512 \mathrm{MB} \text { DDR2 533MHz, unidade de disco } \\
\text { rígido de } 60 \mathrm{~GB} \text {, gravador de DVD/CD (8x), placa de FAX MODEN } 56 \\
\text { KBPS, Tela coloridaSlim com suporte wide screen, anti reflexo e com } \\
\text { tamanho 15.4", placa de vídeo com } 128 \mathrm{MB} \text {, as'da de vídeo externo } \\
\text { padrão VGA, O3 (três portasUSB, placa de rede } 10 / 100 \text { Mbps, teclado } \\
\text { compatível com a língua portuguesa, padrão ABNTII, comunicação sem } \\
\text { fio Wi Fi } 802.11 \mathrm{G} \text {, portas PCMCIA, carregador de bateria, Windows XP- } \\
\text { Porfessional - OEM, maleta para transporte. Alimentação elétrica } \\
\text { automática. bateria recarregável de íons de lítio, } 2 \text { horas de duração. } \\
\text { Peso do equipamento completo até } 2,9 \mathrm{~kg} \text {. }\end{array}$ & \\
\hline
\end{tabular}

\subsection{Instalações e laboratórios de uso geral e especializados}

O Curso Superior de Tecnologia em Hotelaria utilizará os seguintes espaços de laboratórios; Laboratório de reserva e idiomas com capacidade para 21 alunos; Laboratório de Produção de 
Alimentos e Laboratório de Habilidades com capacidade para 40 alunos; laboratório de restaurante com capacidade para 40 convidados e um laboratório de bebidas contendo 20 lugares.

O curso Superior de Tecnologia em Hotelaria utilizará os laboratórios instalados no campus e extra campus para o desenvolvimento de aulas práticas, conforme o quadro a seguir:

\begin{tabular}{|l|l|}
\hline Laboratório & Unidades Curriculares \\
\hline Laboratório de Serviços de Restaurantes & $\begin{array}{l}\text { Operação de Alimentos e Bebidas } \\
\text { Gestão de Eventos na Hotelaria } \\
\text { Língua Espanhola Aplicada } \\
\text { Língua Inglesa Aplicada }\end{array}$ \\
\hline $\begin{array}{l}\text { Laboratório de Produção de Alimentos e } \\
\text { Laboratório de Habilidades de Cozinha }\end{array}$ & $\begin{array}{l}\text { Operação de Alimentos e Bebidas } \\
\text { Segurança dos Alimentos } \\
\text { Segurança do trabalho }\end{array}$ \\
\hline Laboratório de Copa/Cambuza & $\begin{array}{l}\text { Operação de Alimentos e Bebidas } \\
\text { Segurança dos Alimentos } \\
\text { Segurança do trabalho }\end{array}$ \\
\hline Laboratório de Bebidas - Enologia & Operação de Alimentos e Bebidas \\
\hline $\begin{array}{l}\text { Laboratório de reservas e de idiomas } \\
\text { (acesso ao software de gerenciamento } \\
\text { hoteleiro - Desbravador e ao software de } \\
\text { idiomas). }\end{array}$ & $\begin{array}{l}\text { Operação de Recepção e Reservas 1 } \\
\text { Operação de Recepção e Reservas 2 } \\
\text { Língua Inglesa Aplicada 1 } \\
\text { Língua Inglesa Aplicada 2 } \\
\text { Língua Inglesa Aplicada 3 } \\
\text { Língua Espanhola Aplicada } \\
\text { Linguagem e Comunicação }\end{array}$ \\
\hline $\begin{array}{l}\text { Laboratório de Informática (acesso a } \\
\text { Internet). }\end{array}$ & $\begin{array}{l}\text { Operação de Recepção e Reservas 1 } \\
\text { Operação de Recepção e Reservas 2 } \\
\text { Gestão Financeira } \\
\text { Gestão de Materiais } \\
\text { Controladoria } \\
\text { Estatística Aplicada à Hotelaria }\end{array}$ \\
\hline Laboratório de Hotelaria (extra-campus) & $\begin{array}{l}\text { Operação de Governança 1 } \\
\text { Operação de Governança 2 } \\
\text { Operação de Recepção e Reservas 1 } \\
\text { Operação de Recepção e Reservas 2 } \\
\text { Segurança do trabalho }\end{array}$ \\
\hline
\end{tabular}

Ressalta-se que em todos os componentes curriculares terão acesso ao laboratório de informática, como ferramenta de ensino e aprendizagem.

7.8.1 Laboratórios Especializados

\begin{tabular}{|c|c|c|}
\hline \multicolumn{2}{|c|}{$\begin{array}{l}\text { Identificação do Espaço: Laboratório de } \\
\text { Reservas e Idiomas }\end{array}$} & Qtde. de postos de trabalho: 21 \\
\hline Item & Descr & Qto \\
\hline 1 & Cadeiras & 21 \\
\hline 2 & Postos de Trabalho com mesa & 21 \\
\hline 3 & Computadores & 21 \\
\hline 4 & Quadro branco & 1 \\
\hline
\end{tabular}

\begin{tabular}{|c||l|c||}
\hline \hline 5 & Mesa de trabalho & 1 \\
\hline \hline 6 & Armário & 1 \\
\hline
\end{tabular}

\begin{tabular}{|c|c|c|}
\hline $\begin{array}{l}\text { Identificação do Espaço: Laboratório de } \\
\text { Restaurante }\end{array}$ & \multicolumn{2}{|l|}{ Qtde. de postos de trabalho: 40} \\
\hline Item & \begin{tabular}{|c|} 
Descrição \\
\end{tabular} & \\
\hline 1 & Refrigerador/geladeira vertical, med. $2,00 \times 0,70 \times 0,80 \mathrm{~m}$ & 1 \\
\hline 2 & Cadeira em madeira laminada, acabamento em tom ébano. & 53 \\
\hline 3 & Pia lavabo em inox, furo de evacuação, diâmetro de 30 a $36 \mathrm{~cm}$ & 1 \\
\hline 4 & $\begin{array}{l}\text { Máquina de café expresso, de um grupo com moinho dosador, dupla caldeira, } \\
\text { sendo uma caldeira de } 0,45 \text { I para extração do café e uma caldeira de } 2,5 \mathrm{I} \text { para } \\
\text { água quente e vapor o que permite aquecer o leite e tirar café ao mesmo tempo, } \\
\text { medidas L420 x C420 x h380mm. Tensão de } 220 \mathrm{~V} \text { ou bivolt. Frequência de } \\
60 \mathrm{HZ} \text {. Potência de } 1,25 \mathrm{~W} \text {. Moinho dosador: disco em aço diâmetro de } 58 \mathrm{~mm} \text {. } \\
\text { Produtividade de } 3 \text { a } 4 \mathrm{~kg} \text { por hora, motor a } 1400 \text { RPM, capacidade de } \\
\text { campana: } 0,6 \mathrm{~kg} \text { capacidade do dosador: } 0,2 \mathrm{~kg} \text {. Tensão: } 220 \mathrm{~V} \text { - Frequência } \\
60 \mathrm{HZ} \text {, Potencia } 250 \mathrm{~W} \text {. }\end{array}$ & 2 \\
\hline 5 & $\begin{array}{l}\text { Mesa de encosto em aço inox com duas cubas à esquerda med. } \\
\text { 2000x700x850mm }\end{array}$ & 1 \\
\hline 6 & $\begin{array}{l}\text { Buffet fechado de encosto em aço inox com espelho em formato em "L"; } \\
\text { medidas do lado maior } 3,65 \times 0,70 \times 0,85 \mathrm{~m} \text {; lado menor } 2,00 \times 0,70 \times 0,85 \mathrm{~m} \text {. }\end{array}$ & 1 \\
\hline 7 & $\begin{array}{l}\text { Banco para bar em madeira vergada. Pés dianteiros } 0,72 \mathrm{~m} \text {. Pés traseiros } 1,02 ; \\
\text { Assento } 26 \times 38 \mathrm{~cm} \text { em madeira laminada. Acabamento em ébano. }\end{array}$ & 14 \\
\hline 8 & $\begin{array}{l}\text { Mesa auxiliar em madeira vergada com rodízios. Altura dos pés } \\
\text { 0,77m.Profundidade 0,40m; Largura } 0,80 \mathrm{~m} \text {, com gaveta e prateleira } \\
\text { intermediária em tom ébano. }\end{array}$ & 4 \\
\hline 9 & $\begin{array}{l}\text { Mesa redonda com } 0,77 m \text { de altura e pés em madeira vergada, } 1,20 \mathrm{~m} \text { de } \\
\text { diâmetro do tampo; Acabamento em tom ébano. }\end{array}$ & 8 \\
\hline 10 & $\begin{array}{l}\text { Mesa quadrada, med. } 0,80 \times 0,80 \mathrm{~m}, 0,768 \mathrm{~m} \text { de altura. Acabamento em tom } \\
\text { ébano. }\end{array}$ & 6 \\
\hline 11 & $\begin{array}{l}\text { Mesa retangular; med. } 1,20 \times 0,80 \mathrm{~m}, 0,768 \mathrm{~m} \text { de altura; acabamento em tom } \\
\text { ébano. }\end{array}$ & 5 \\
\hline 12 & $\begin{array}{l}\text { Mesa para bar em madeira vergada tampo em MDF com diâmetro de } 70 \mathrm{~cm} \\
\text { acabamento em tom ébano }\end{array}$ & 4 \\
\hline 13 & $\begin{array}{l}\text { Balcão com estrutura em MDF } 18 \mathrm{~mm} \text {. Cor: preto revestimento em laminado } \\
\text { melanimico, puxadores em aço inox. Parte superior em granito tipo: São Gabriel }\end{array}$ & 1 \\
\hline 14 & $\begin{array}{l}\text { Armário para pendurar na parede com estrutura em MDF } 18 \mathrm{~mm} \text {. Revestimento } \\
\text { em laminado melaminico. Cor: preto, portas e gavetas com acabamento em } \\
\text { vidro e alumínio }\end{array}$ & 1 \\
\hline 15 & $\begin{array}{l}\text { Aparador/balcão com estrutura em MDF } 18 \mathrm{~mm} \text { revestimento em laminado } \\
\text { melaminico. Cor preto, estrutura de apoio em alumínio. Pés com rodízios. }\end{array}$ & 4 \\
\hline 16 & $\begin{array}{l}\text { Bebedouro elétrico de coluna para garrafão, aço inox com pintura eletrostática } \\
\text { anti corrosiva, componentes internos atóxicos }\end{array}$ & \\
\hline
\end{tabular}

Identificação do Espaço: Laboratório Cambuza
\begin{tabular}{|c|l|c|}
\hline \multicolumn{1}{|c|}{ Qtde. de poscrição } & Quantidade \\
\hline Item de trabalho: 20 \\
\hline 1 & Coifa em aço inox, med. 0,68 x 0,68m. & 1 \\
\hline 2 & Prateleira superior lisa, aço inox, mãos francesas; med 1,20 x 0,30cm. & 2 \\
\hline 3 & Cortador/Fatiador de frios automático, desmontável & 1 \\
\hline
\end{tabular}




\begin{tabular}{|c|c|c|}
\hline \multicolumn{3}{|c|}{ Identificação do Espaço: Laboratório Cambuza Qtde. de postos de trabalho: 20} \\
\hline 4 & $\begin{array}{l}\text { Buffet fechado de centro em aço inox; } 1 / 2 \text { prateleira intermediária, } 1 / 2 \\
\text { armário com chaves med. } 3,50 \times 0,70 \times 0,85 \mathrm{~m} \text {. }\end{array}$ & 1 \\
\hline 5 & $\begin{array}{l}\text { Refrigerador doméstico, duplex, duas portas, capacidade minima de } \\
\text { refrigeração } 310 \text {, sistema frost free }\end{array}$ & 1 \\
\hline 6 & $\begin{array}{l}\text { Máquina de lavar copos, cap. 1000/1200peças/hora em chapas } \\
\text { inox;2,8kw, } 220 \mathrm{~V}, 60 \mathrm{~Hz} \text {; med 0,45 x 0,51 x 0,64m. }\end{array}$ & 1 \\
\hline 7 & $\begin{array}{l}\text { Máquina de gelo em cubo, dimensões } 54 \times 57 \times 110 \mathrm{~cm} \text {, massa } 50 \mathrm{~kg} \\
\text { potencia elétrica de } 1 / 3 \mathrm{HP} \text {, fluido refrigerado R-134 e carga de } 190 \mathrm{~g} \text {, } \\
\text { nominal } 4,7 \mathrm{~A} \text { e } 220 \mathrm{~V} \text {, consumo } 630 \mathrm{~W} / \mathrm{h}\end{array}$ & 1 \\
\hline 8 & Buffet fechado em aço inox, med 0,80 x 0,70 x0,85m. & 1 \\
\hline 9 & $\begin{array}{l}\text { Mesa lisa de centro sem espelho traseiro e com prateleira inferior, med. } \\
0,40 \times 0,40 \times 0,85 \mathrm{~m}\end{array}$ & 1 \\
\hline 10 & $\begin{array}{l}\text { Mesa lisa de encosto em aço inox com espelho traseiro } \\
1 \text { cuba. Med: } 1200 \times 700 \times 850 \mathrm{~mm}\end{array}$ & 1 \\
\hline 11 & $\begin{array}{l}\text { Centrífuga industrial de sucos totalmente em inox; potência de 0,5CV - } \\
220 \mathrm{~V} \text {. }\end{array}$ & 1 \\
\hline 12 & $\begin{array}{l}\text { Forno micro-ondas, capacidade entre } 35 \text { e } 40 \text { I, porta com vidro } \\
\text { temperado, timer, trava de segurança, painel digital } 220 \mathrm{~V}, 60 \mathrm{~Hz} \text {, } \\
\text { monofásico }\end{array}$ & 1 \\
\hline 13 & $\begin{array}{l}\text { Balança eletrônica de mesa com capacidade de até } 15 \mathrm{~kg} \text { e divisão de } \\
5 \mathrm{~g} \text { com tensão de } 220 \mathrm{~V} \text {. }\end{array}$ & 1 \\
\hline 14 & Espremedor de frutas elétrico, em aço inox 220V & 1 \\
\hline 15 & Tostadeira elétrica de pães em aço inox 220V & 1 \\
\hline 16 & Fogão a gás de mesa, 2 bocas, med $20 \times 40 \times 6 \mathrm{~cm}$ coleta de residuos & 1 \\
\hline 17 & $\begin{array}{l}\text { Mesa lisa de centro sem espelho traseiro e com prateleira em aço inox } \\
\text { med. } 100 \times 70 \times 85 \mathrm{~cm}\end{array}$ & 1 \\
\hline 18 & Coifa de aço inox me: $680 \times 680 \mathrm{~mm}$ & 1 \\
\hline 19 & $\begin{array}{lccccccc}\begin{array}{l}\text { Mesa lisa de encosto em } \\
2 \text { cubas. Med: } 3500 \times 700 \times 850 \mathrm{~mm}\end{array} & & & & & \\
\end{array}$ & \\
\hline 20 & $\begin{array}{l}\text { Forno elétrico com fundo de lastro/pedra refratária, camara com } \\
\text { regulagem de temperatura porta em vidro refratario. Med. Aproximadas: } \\
700 \times 600 \times 250 \mathrm{~mm}\end{array}$ & 1 \\
\hline
\end{tabular}

\begin{tabular}{|c|c|c|c|}
\hline \multicolumn{2}{|c|}{$\begin{array}{l}\text { Identificação do Espaço: Laboratório de Habilidades } \\
\text { Básicas de Cozinha }\end{array}$} & \multicolumn{2}{|c|}{ Qtde. de postos de trabalho: 20} \\
\hline & & \multicolumn{2}{|c|}{ Área construída: $156,95 \mathrm{~m}^{2}$} \\
\hline Item & Descrição & & Quantidade \\
\hline 1 & $\begin{array}{l}\text { Liquidificador para cozinha com capacidad } \\
\text { em aço inox controle com função de velocio } \\
\text { tensão de } 220 \mathrm{~B} \text {. }\end{array}$ & $\begin{array}{l}\text { de } 2 \text { I com estrutura e copo } \\
\text { ides e função pulsar e com }\end{array}$ & 1 \\
\hline 2 & $\begin{array}{l}\text { Forno micro-ondas, capacidade entre } 35 \\
\text { temperado, timer, trava de segurança, } \\
\text { monofásico }\end{array}$ & $\begin{array}{l}\text { e } 40 \mathrm{I} \text {, porta com vidro } \\
\text { ainel digital } 220 \mathrm{~V}, 60 \mathrm{~Hz} \text {, }\end{array}$ & 2 \\
\hline 4 & $\begin{array}{l}\text { Robot Cutter profissional com inferior a } 70 \\
\text { de apoio em material atóxico estampado em } \\
\text { comando eletrônico. Totalmente fabricado } \\
\text { AISI } 304 \text { liga } 18.10 \text { medindo aproximada } \\
\text { potencia } 1 \mathrm{HP}-380 \mathrm{~V} \text { - Trifásico }-60 \mathrm{~Hz} \text {. }\end{array}$ & $\begin{array}{l}\text { o, dotado de tampa e plano } \\
\text { olicarbonato com painel de } \\
\text { chapas de aço inoxidável } \\
\text { ente } 240 \times 310 \times 420 \mathrm{~mm}\end{array}$ & 1 \\
\hline 5 & Misturador combinado mixer e batedeira & ara uso a mão com função & 1 \\
\hline
\end{tabular}

\begin{tabular}{|c|c|c|}
\hline $\begin{array}{l}\text { Identif } \\
\text { Básica }\end{array}$ & \begin{tabular}{l|l} 
ação do Espaço: Laboratório de Habilidades & Qtde. de postos de trabalh \\
de Cozinha
\end{tabular} & \\
\hline & $\begin{array}{l}\text { batedeira e triturador, monofásico } 220 \mathrm{~V}-60 \mathrm{hz} \text { com frustra e bastão } \\
\text { misturador }\end{array}$ & \\
\hline 8 & $\begin{array}{l}\text { Buffet aberto em aço inox pés e sapatas de nivelamento em nylon, com } \\
\text { espelho. Medindo 2,00x0,70x0,85m, com } 4 \text { portas e com chave e uma } \\
\text { prateleira interna intermediária. }\end{array}$ & 2 \\
\hline 9 & $\begin{array}{l}\text { Buffet fechado em aço inox AISI } 304 \text { com bitola } 22 \text { (e=0,8mm), tampo } \\
\text { inox } 18 \text { liga } 18.8 \text { AISI } 304 \text { pés e sapatas de nivelamento em nylon, com } \\
\text { espelho. Medindo } 1,20 \times 0,70 \times 0,85 \mathrm{~m} \text {, com } 2 \text { portas e com chave e uma } \\
\text { prateleira interna intermediária }\end{array}$ & 1 \\
\hline 10 & Balança Analógica de mesa com capacidade de até $5 \mathrm{Kg}$ e divisão 10g. & 2 \\
\hline 11 & $\begin{array}{l}\text { Fogão a gás de mesa, de sobrepor, com duas bocas, medindo } \\
\text { aproximadamente } 20 \times 40 \times 6 \mathrm{~cm} \text {, com os botoes na dimensao da largura, e } \\
\text { apoio para coleta de resíduos }\end{array}$ & 7 \\
\hline 12 & $\begin{array}{l}\text { Pia Lavabo em inox AISI } 304 \text { (18/8), espessura } 1 \mathrm{~mm} \text {, para montagem } \\
\text { mural, com furo de evacuação, com diâmetro de } 30 \text { a } 36 \mathrm{~cm} \text {, com furo da } \\
\text { torneira em } 33 \mathrm{~mm} \text {. }\end{array}$ & 2 \\
\hline 13 & Moedor elétrico de carne & 1 \\
\hline 14 & Balança de precisão eletrônica de mesa, cap. $15 \mathrm{~kg}$, divisão $5 \mathrm{~g}$, 220V & 2 \\
\hline 15 & $\begin{array}{l}\text { Forno elétrico combinado, cinco funções: vapor, ar seco, banho maria, } \\
\text { combinado e regeneração, med. } 740 \times 1000 \times 575 \mathrm{~mm}\end{array}$ & 1 \\
\hline 16 & Serra industrial de de fita para ossos com mesa em aço 220V & 1 \\
\hline 17 & 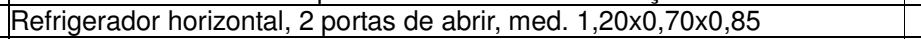 & 1 \\
\hline 18 & Mesa de encosto em aço inox com duas cubas med: $600 \times 500 \times 350 \mathrm{~mm}$ & 1 \\
\hline 19 & Prateleira superior lisa em aço inox med. $1000 \times 300 \mathrm{~mm}$ & 3 \\
\hline 20 & $\begin{array}{l}\text { Batedeira planetária de mesa, tacho removível em aço inox } 300 \mathrm{~W} \text { de } \\
\text { potência com tres tipos de batedores: gancho, globo e palma, } 110 \mathrm{~V}, 60 \mathrm{~Hz} \text {, } \\
\text { tomada tripolar, } 10 \mathrm{~kg}\end{array}$ & 1 \\
\hline 21 & Bebedouro elétrico de pressão, branco 220V & 1 \\
\hline 22 & Forno elétrico com fundo de lastro/pedra refratária, duas camaras & 1 \\
\hline 23 & $\begin{array}{l}\text { Módulo de cocção acadêmico em aço inox AISI } 304 \text {. Composição: } 3 \\
\text { módulos, fogão, } 3 \text { módulos pias e } 3 \text { módulos de mesas de apoio }\end{array}$ & 4 \\
\hline 24 & $\begin{array}{l}\text { Fogão a gás tipo industrial } 4 \text { bocas com forno, medidas aproximadas: } \\
\text { 80x80cm. Queimadores front simples e traseiros duplos. Corpo em aço } \\
\text { inox AISI 304, sapatas de nivelamento em nylon. }\end{array}$ & 1 \\
\hline 25 & $\begin{array}{l}\text { Chair broiler / Chapa lisa quente em aço inox AISI } 304 \text { pedras refratárias } \\
\text { de alto poder calorífico no Chair Broiler, bandeja coletora de resíduos e } \\
\text { gorduras. Sapatas niveladoras. }\end{array}$ & 1 \\
\hline 26 & $\begin{array}{l}\text { Fritadeira em inox } 304 \text { medidas aproximadas: } 40 \times 80 \mathrm{~cm} \text {. Tipo água e óleo } \\
\text { com capacidade para } 18 \mathrm{~L} \text {. Dois cestos fritadores em aço. }\end{array}$ & 1 \\
\hline 27 & $\begin{array}{l}\text { Máquina de gelo em cubo, dimensões } 54 \times 57 \times 110 \mathrm{~cm} \text {, massa } 50 \mathrm{~kg} \\
\text { potencia elétrica de } 1 / 3 \mathrm{HP} \text {, fluido refrigerado } \mathrm{R}-134^{\mathrm{a}} \text { e carga de } 190 \mathrm{~g} \text {, } \\
\text { nominal } 4,7 \mathrm{~A} \text { e } 220 \mathrm{~V} \text {, consumo } 630 \mathrm{~W} / \mathrm{h}\end{array}$ & 1 \\
\hline 28 & $\begin{array}{l}\text { Carro para transporte de Gns munidos de kits Gns contendo } 3 \text { Gns para } \\
\text { ovos, } 3 \text { para frituras, } 8 \text { Gns esmaltadas e } 2 \text { Gns tipo grelha frissada } \\
\text { teflonada para grelhados. }\end{array}$ & 1 \\
\hline
\end{tabular}

Identificação do Espaço: Laboratório de

Qtde. de postos de trabalho: 20

Descrição

\begin{tabular}{c|l|c|} 
Item & Descrição & Quantidade \\
\hline 1 & Buffet fechado em aço inox med. 1,20 x 0,70 x 0,85m, 2 portas com chave & 2 \\
\hline
\end{tabular} 


\begin{tabular}{|c|c|c|}
\hline $\begin{array}{l}\text { Identifi } \\
\text { Bebida: }\end{array}$ & \begin{tabular}{l|l} 
ção do Espaço: Laboratório de & Qtde. de postos de trabalho: $2 C$ \\
Enologia &
\end{tabular} & \\
\hline 2 & $\begin{array}{l}\text { Pia lavabo em aço inox, montagem em mural, furo de evacuação, diâmetro } \\
\text { de } 30 \text { a } 36 \mathrm{~cm}\end{array}$ & 1 \\
\hline 3 & $\begin{array}{l}\text { Liquidificador capacidade } 21 \text {, estrutura e copo em inox, controle de } \\
\text { velocidade e pulsar, } 220 \mathrm{~V}\end{array}$ & 1 \\
\hline 4 & Buffet fechado em aço inox; MED. 0,80 X 0,70 X 0,85m & 2 \\
\hline 5 & refrigerador/geladeira duplex & 1 \\
\hline 6 & $\begin{array}{l}\text { Máquina de lavar copos, capacidade } 100 / 1200 \text { peças/hora em chapas inox } \\
28 \mathrm{Kw}, 220 \mathrm{~V}, 6 \mathrm{~Hz} \text {; med. } 0,45 \times 5,109 \times 0,64 \mathrm{~m}\end{array}$ & 1 \\
\hline 7 & $\begin{array}{l}\text { Mesa trapezoidais, med } 1,15 \times 0,65 \mathrm{~m} \text {, tampo aglomerado } \\
\text { revestido em laminado argila, bordas arredondadas }\end{array}$ & 12 \\
\hline 8 & Mesa de encosto em aço inox com 1 cuba med. 1,20 x 0,70 x 0,85m & 1 \\
\hline 9 & Cadeira de madeira laminada, acabamento tom ébano & 23 \\
\hline 10 & $\begin{array}{l}\text { Máquina de gelo em cubo, dimensões } 54 \times 57 \times 110 \mathrm{~cm} \text {, massa } 50 \mathrm{~kg} \\
\text { potencia elétrica de } 1 / 3 \mathrm{HP} \text {, fluido refrigerado } \mathrm{R}-134^{\mathrm{a}} \text { e carga de } 190 \mathrm{~g} \text {, } \\
\text { nominal } 4,7 \mathrm{~A} \text { e } 220 \mathrm{~V} \text {, consumo } 630 \mathrm{~W} / \mathrm{h}\end{array}$ & 1 \\
\hline 11 & $\begin{array}{l}\text { Conjunto de móveis para bar/balcãoe armário MDF } 18 \text { mm com } \\
\text { revestimento em fórmica, armário com portas em vidro e lâmpadas } \\
\text { dicróicas }\end{array}$ & 1 \\
\hline 12 & $\begin{array}{l}\text { Forno micro-ondas, capacidade entre } 35 \text { e } 40 \text { I, porta com vidro } \\
\text { temperado, timer, trava de segurança, painel digital } 220 \mathrm{~V}, 60 \mathrm{~Hz} \text {, } \\
\text { monofásico }\end{array}$ & 1 \\
\hline 13 & $\begin{array}{l}\text { Banco para bar em madeira vergada, pés dianteiros } 72 \mathrm{~cm} \text { pés traseiros } \\
102 \mathrm{~cm} \text { assento } 26 \times 38 \mathrm{~cm} \text { em madeira laminada acabamento em tom } \\
\text { ébano. }\end{array}$ & 3 \\
\hline 14 & Buffet aberto em aço inox med. $1,00 \times 0,70 \times 0,85 \mathrm{~m}$ & 1 \\
\hline 15 & Armário de aço fechado $2,00 \times 0,4 \times 1,30 \mathrm{~m}$ com 2 portas corrediças & 1 \\
\hline 16 & Mesinha lisa de centro em aço inox med. $55 \times 55 \times 35 \mathrm{~cm}$ & 1 \\
\hline
\end{tabular}

\subsubsection{Laboratório de Hotelaria (Hotel)}

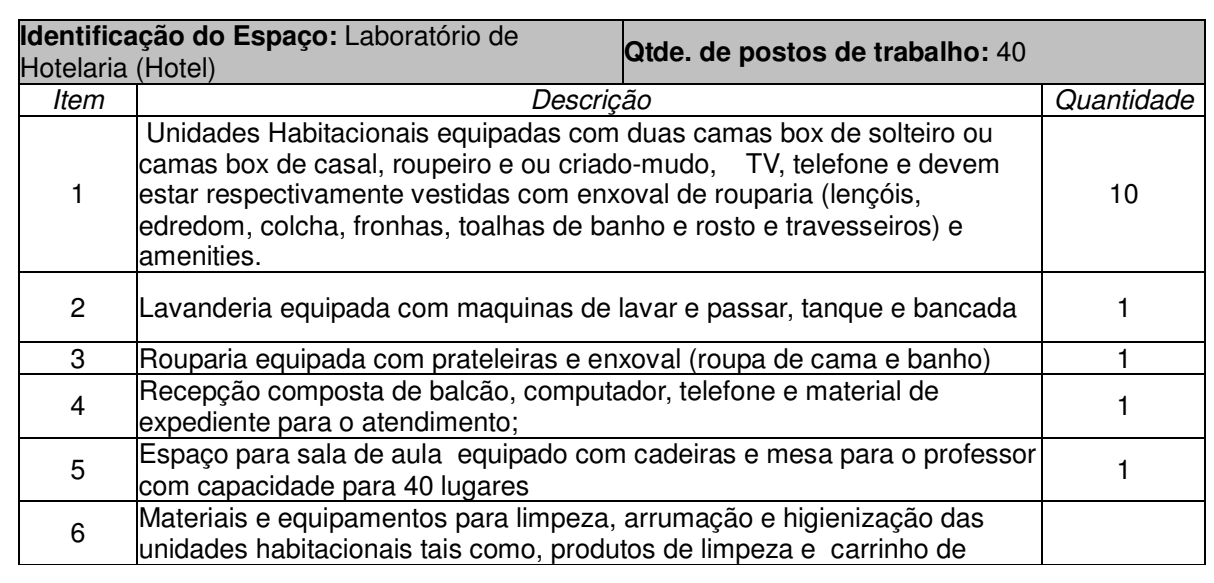

Identificação do Espaço: Laboratório de

Hotelaria (Hotel)

camareira

Qtde. de postos de trabalho: 40

O Laboratório de Hotelaria funciona por meio da contratação pessoa jurídica para a locação de espaço físico para realização das aulas práticas no Curso Superior de Tecnologia em Hotelaria do Câmpus Florianópolis-Continente do IFSC. As aulas realizadas em hotéis em operação proporcionam o desenvolvimento de competências que visam atingir a qualificação necessária do sujeito para o seu exercício profissional. Em aulas práticas é que acontece a integração da teoria e da prática e os alunos conseguem relacionar os conhecimentos técnicos aprendidos em sala de aula com a realidade operacional vivenciada no hotel, o que permite catalisar o ensino e a aprendizagem (Anexo o contrato de locação do hotel na atualidade).

É parte do processo de construção para ampliação das instalações do Campus FlorianópolisContinente dois laboratórios para Hotelaria: Laboratório Modelo de Governança e o Laboratório Modelo de Recepção. Dessa forma, tão logo as obras sejam concluídas, o curso Superior de Tecnologia em Hotelaria poderá contar também com sala de aula/ laboratórios com modelo de uma unidade habitacional e com modelo de uma recepção a serem instalados no Campus. .

A) Laboratório Modelo de Hospedagem / Governança: descritivo das futuras instalações Quarto:

a) Armário: Armário em MDF revestido em laminado de madeira Zebrano. Duas portas de correr em vidro mini boreral $4 \mathrm{~mm}$ e estrutura metálica com acabamento cromado e portas com chaveamento. Composto de 2 cabideiros, 4 gavetas e 7 prateleiras. Dimensões: $200 \times 60 \times 270$ Quantidade: 01 unidade b) Gaveteiro: Gaveteiro em MDF revestido com laminado de madeira Zebrano. Três gavetas com chaveamento. Base com 4 rodízios cromados com rodas em gel polycristal transparente $(2 \mathrm{com}$
travas) com altura de $50 \mathrm{~mm}$. Puxadores com acabamento cromado, modelo Tess da Archi travas) com altura de $50 \mathrm{~mm}$. Puxadores com acabamentores. Dimensões: $45 \times 50 \times 55$. Quantidade: 01 unidade

Puxadores. Dimensões: $45 \times 50 \times 55$. Quantidade: 01 unidade
c) Painel: Conjunto de painel composto por chapa de MDF revestido em laminado

c) Painel: Conjunto de painel composto por chapa de MDF revestido em lamina entrelaçado Zebrano, papel de parede em painel fotográfico e

cabeceira de capitonê (painel de madeira estofado sobre espuma D28)

em couro ecológico na cor a ser definida pela fiscalização. O painel na cabeceira deverá conte os interruptores para controle de iluminação e condicionador de ar e tomadas para abajures telefone. Dimensões: 290x10x270. Quantidade 01 conjunto.

d) Cadeira fixa: Cadeira Modelo Esteirinha Charles Eames ou similar com base em Alumínio fixa assento com encosto alto revestido em Couro Ecológico na cor branca. Sistema de regulagem de altura a gás. Dimensões: $112 \times 58$ × 50. Quantidade: 02 unidades.

e) Cadeira com rodízios: Cadeira Modelo Esteirinha Charles Eames ou similar com base em Alumínio c/ Rodízios, assento com encosto alto revestido em Couro Ecológico na cor branca. Sistema de regulagem de altura a gás. Dimensões: 112 × 58 x 50. Quantidade: 01 unidade.

f) Escrivaninha com gaveteiro independente: Escrivaninha em MDF revestido com laminado de madeira Zebrano. Base com 4 rodízios cromados com rodas em gel polycristal transparente com travas). Dimensões: $160 \times 73 \times 75$. Quantidade: 01 unidade.

Gaveteiro em MDF revestido com laminado melamínico na cor branca. Três gavetas com chaveamento contidade: 01 unidade.

g) Aparador para TV com nicho para frigobar: Aparador para TV com nicho para frigobar e prateleira aberta, em MDF revestido com laminado de madeira Zebrano. Base com 4 rodízios cromados com rodas em

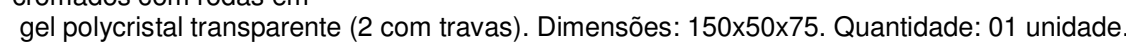

h ) Mesa: Mesa redonda com tampo em vidro $10 \mathrm{~mm}$ com acabamento bisotê e pés em aço inox com acabamento polido com regulagem de altura. Dimensões: 90 (diâmetro)x75 (altura) Quantidade: 01 unidade. 
i) Plataforma para frigobar: Plataforma para frigobar em MDF evestido com laminado de madeira Zebrano. Base com 4 rodízios cromados com rodas em gel polycristal transparente (2 com travas) com altura de 50mm. Dimensões: 50x51. Quantidade: 01 unidade.

\section{Banheiro:}

a) Bancada: Bancada para cuba de sobrepor com 2 prateleiras abertas e espelho de $30 \mathrm{~cm}$,em granito preto piracaia bordas com $90^{\circ} \mathrm{e} 180^{\circ}$. Dimensões: $200 \times 50 \times 80$.Quantidade: 01 unidade.

\section{Governança:}

a) Painel em cortiça: Painel em cortiça com moldura metálica com acabamento cromado. Dimensões: 170x5x100. Quantidade: 01 unidade.

b)) Armário em L: Armário em MDF com laminado em madeira Rádica Olivo. Acabamentos em $90^{\circ}$ e $180^{\circ}$.

Puxadores modelo Nero da Archi puxadores, acabamento grafite. Com prateleiras e dois cabideiros para vassouras com extração deslizante. Quatro portas de correr com chaveamento. Dimensões: conforme projeto. Quantidade: 01 unidade.

c) Armário aberto: Armário aberto com 6 prateleiras vazadas em aço inox AISI304, acabamentos sem emendas. Dimensões: 263×60x275. Quantidade: 01 unidade.

d) Escrivaninha: Escrivaninha com 3 gavetas e nicho para estabilizador e gabinete em MDF com laminado em madeira Rádica Olivo. Acabamentos em $90^{\circ}$ e $180^{\circ}$. Puxadores modelo Nero da Archi puxadores, acabamento grafite. Dimensões: 168x81x74. Quantidade: 01 unidade.

e) Arquivo: Arquivo com 4 gavetas para pastas suspensas em MDF com laminado em madeira Rádica Olivo. Acabamentos em $90^{\circ}$ e $180^{\circ}$. Puxadores modelo Nero da Archi puxadores, acabamento grafite. Dimensões: 50x72×151. Quantidade: 01 unidade.

f) Cadeira digitador: Cadeira digitador com base cromada com regulagem a gás e mecanismo com regulagem de movimento da inclinação e altura do encosto atendendo rigorosamente as normas NR17 e NBR13962 com braços reguláveis. Base cromada e forro do assento em couro ecológico na cor preta. Quantidade: 01 unidade.

\section{B) Laboratório Modelo de Recepção: descritivo das futuras instalações}

a) Espelho: Espelho 1 face com moldura com acabamento cromado. Dimensões: 400x97. Quantidade: 01 unidade.

b) Mesa lateral: Mesa lateral, confeccionada, em tubo de aço carbono sae 1010/20 de secção eliptico de 20x45, parede $12 \mathrm{~cm}$ com costura longitudinal. soldado com processo migg

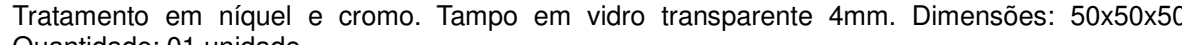
Quantidade: 01 unidade.

c) Poltrona: Poltrona Gandola, design Pierre Paulin ou similar. Base giratória em alumínio fundido e polido com concha em fibra estofada em Velosuede na cor marrom. Quantidade: 02 unidades.

d) Sofá: Sofá 3 lugares modelo LC3, design Le Corbusier com estrutura em aço inox tubula polido brilhante, percinta elástica, revestida com espuma de poliuretano (D28/assento, D23/encosto/braços), manta acrílica e couro ecológico na cor preta.. Quantidade 01 unidade. Dimensões: $236 \times 73 \times 65$

e) Mesa de recepção: Mesa para recepção em MDF com acabamento em laminado de madeira Carvalho. A estrutura da base é em tubo de aço cromado com o apoio de sapatas reguláveis. Tampo para atendimento em vidro transparente $8 \mathrm{~mm}$ com espaçadores em aço cromado. Estrutura interna com suporte para 4 gabinetes. Acabamentos com $90^{\circ}$ e $180^{\circ}$. Dimensões: conforme projeto. Quantidade: 01 unidade.

f) Cadeira digitador com rodízios: Cadeira digitador com base cromada com regulagem a gás mecanismo com regulagem de movimento da inclinação e altura do encosto atendendo

rigorosamente as normas
NR17 e NBR13962 com braços reguláveis. Base cromada e forro do assento em couro ecológico na cor preta. Quantidade:05 unidades.

f) Cadeira. Quantide:05 unidades. mecanismo com rés normas

NR17 e NBR13962. Base cromada e forro do assento em couro ecológico na cor preta Quantidade:02 unidades.

g) Mesa: Mesa, confeccionada, em tubo de aço carbono sae 1010/20 de secção eliptico de 20x45 parede $12 \mathrm{~cm}$ com costura longitudinal. soldado com processo migg. Tratamento em níquel e cromo. Tampo em vidro transparente $4 \mathrm{~mm}$. Gaveteiro com chaveamento com duas gavetas, uma para pasta suspensa

em MDF revestido com laminado de madeira Carvalho. Fechamento tipo feche-toque. Suporte para gabinete em MDF revestido com laminado de madeira Carvalho. Base com 4 rodízios cromados com rodas em gel polycristal transparente (2 com travas). Quantidade 01 unidade. Dimensões: $150 \times 80 \times 76$. 


\section{REFERÊNCIAS}

ABIH - ASSOCIAÇÃO BRASILEIRA DA INDÚSTRIA HOTELEIRA (SANTA CATARINA). Números

do setor hoteleiro em Santa Catarina. Março de 2007. Disponível em www.abih-sc.com.br Acesso em 02 de maio de 2008.

BARRETO, Ana Isaia. As Contribuições das Relações Públicas para a Comunicação Mercadológica Hoteleira : A Rede Plaza De Hotéis, Resorts \& Spas Brasil. Curso de Comunicação Social. PUC-RS, 2007. (Monografia de Graduação);

BRASIL, Estudo de competitividade dos 65 destinos indutores do desenvolvimento turístico regional. FGV, MTUR, SEBRAE, 2011.

BRASIL. Informações sobre o turismo brasileiro - Ministério do Turismo - www.turismo.gov.br Acesso em 20/05/2012

CAMPOS, L.C; GONÇALVES, M.H. Introdução ao Turismo e Hotelaria. Rio de Janeiro: Senac, 1998.

DIEESE. Pesquisa do Setor de Turismo e Hospitalidade da Região Metropolitana de Florianópolis - SC. 2008

EMBRATUR - INSTITUTO BRASILEIRO DE TURISMO. Boletim de Desempenho Econômico do Turismo. 2008. Disponível em www.turismo.org.br. Acesso em 2012.

EMBRATUR (2010). Anuário Estatístico de Turismo de 2009. Disponível em: www.turismo.org.br. Acesso em 2012.

IBGE. Pesquisa de Hospedagem de 2011. Disponível em: www.ibge.gov.br. Acesso em 02/04/2012.

IFSC. Informações sobre a Instituição. Disponível em: www.ifsc.edu.br. 2009

IHF - Internationa Handball Federation. Final Report Of The World Championship 2011.

Mondo, Tiago Savi; Costa, Jane I. P. (2011) "Influencia de La Comunicación de marketing em La captacion de clientes: un estúdio sobre La percepción de La publicidad em La hotelería Del Estado de Santa Catarina, Brasil." Estudios Y perspectivas em Turismo. 20(2): 367-383.

MTur. Estatísticas Básicas do Turismo - Ministério do Turismo. Disponível em: www.turismo.gov.br. Acesso em; 20/11/2010.

PLANO MUNICIPAL DE TURISMO DE FLORIANÓPOLIS. 2011.

SANTOS, Fabíola Martins dos. Uma análise histórico-espacial do setor hoteleiro no núcleo urbano central de Florianópolis (SC). Dissertação de Mestrado. Balneário Camboriú: UNIVALI, 2005.

SANTUR (2009). Estudo de Demanda Turística 2009. Disponível em: www.santur.sc.gov.br. Acesso em: 01/02/2010.

SEBRAE-SC. Santa Catarina em Números 2010. Disponível em: http://www.sebrae sc.com.br/scemnumero. Acesso em 02/08/2012.

WTTC. Relatório Anual de 2008. World Tourism and Travel Concil, 2009. Disponível em: 
MINISTÉRIO DA EDUCAÇÃO

OAOSONAL TECNOLÓGICA CATARINA.

PROJETO PEDAGÓGICO DE CURSO - PPC

CAMPUS FLORIANÓPOLIS-CONTINENTE

\section{CURSO SUPERIOR DE TECNOLOGIA EM GASTRONOMIA}

Eixo Tecnológico: TURISMO, HOSPITALIDADE E LAZER

\author{
Florianópolis, junho de 2014
}

DADOS DA IES

1.1 Mantenedora

1.2 Mantida - Campus Proponente

3 Nome do responsável/representante pelo projeto/oferta . .............

1.4 Contex responsavelrepresentante pelo projeto/oterta.

1.4 Contextualizaçao da IES.

2.1 Requisitos Legais

Dados para preenchimento do diploma ...........................................................................

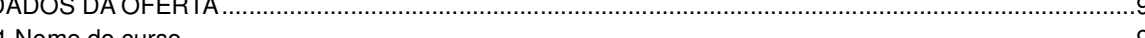

3.2 Modalidad

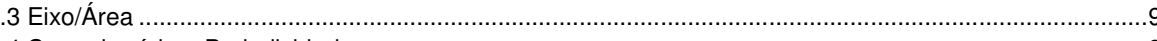

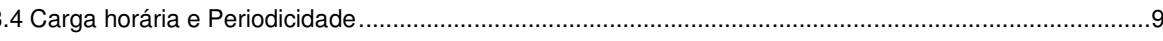

3.5 Integralização

3.6 Dados da oferta...

4.2 Justificativa da oferta do curs

4.3 Objetivos do curso

4.3.1 Objetivos do curso..

4.3.2 Objetivos do curso

4.4 Perfil Profissional do Egresso...

4.5 Competências profissionais

4.6 Áreas de atuação

4.7 Possívis postos de trabalho....

4.8 Ingresso ao curso

5 ESTRUTURA CURRICULAR DO CURSO..

5.1 Organização didático pedagógica

5.2 Articulação Ensino Pesquisa e Extensão

5.3 Metodologia

5.4 Representação Gráfica do Perfil de Formação

5.5 Matriz Curricular

5.6 Certificações Intermediárias

5.7 Componentes curriculares

5.8 Atividades complementa

.8 Avidas complementar

5.9 Avallação do Processo

5.11 Estágios curricular e Acompanhamento do estágio

5.12 Prática supervisionada nos serviços ou na indústria, e acompanhamento das práticas

supervisionadas

5.13 Atendimento ao discente

5.14 Atividades de Tutoria (para cursos EAD)

5.15 Critérios de aproveitamento de conhecimentos e experiências anteriores.

5.16 Avaliação do projeto do curso

5.17 Incentivo a pesquisa, a extensão e a produção cientifica e tecnológica

mpresas)

5.18 Integração (rede pública/licenciatura, rede regional e SUS/saúde, empresas)

6 CORPO DOCENTE ETUTORIAL

6.1 Coordenador do Curso

6.2 Corpo Docente

6.3 Corpo Administrativo

6.4 Núcleo Docente Estruturante 9 99 . .9 .8 8 .9 .. .9 
6.5 Colegiado do Curso

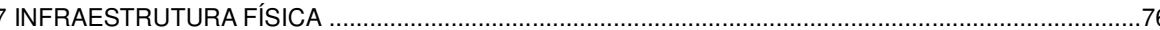

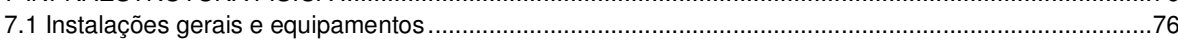

7.2 Sala de professores e salas de reuniões ....................76

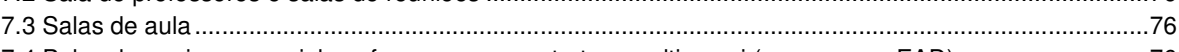

7.4 Polos de apoio presencial, se for o caso, ou estrutura multicampi (para cursos EAD) ……...................76

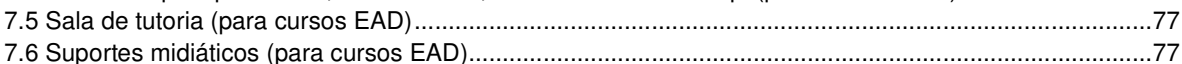

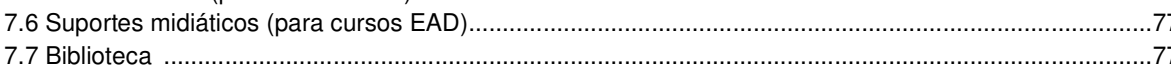

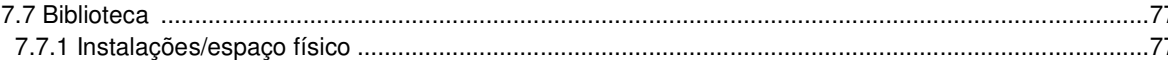

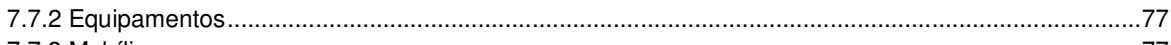

7.7.3 Mobília ..........

7.7.4 Acervo bibliogŕfico

7.7 .5 Acro dos alnos equipamentos informática

7.7 .5 Acesso dos alunos e equipanentos intmatica

.97

\section{DADOS DA IES}

1.1 Mantenedora

Nome da Mantenedora: Instituto Federal de Educação, Ciência e Tecnologia de Santa Catarina

Endereço: Rua 14 de julho

Número: 150

Bairro: Coqueiros

CEP: $88075-010$

Cidade: Florianópolis

Estado: SC

Telefone(s): (48) 38779000

Ato Legal: Lei 11.892 de 29 de dezembro de 2008

Endereço WEB: www.ifsc.edu.br

Reitora: Maria Clara Kaschny Schneider

\section{Mantida - Campus FLORIANÓPOLIS-CONTINENT}

Nome da Mantida: Instituto Federal de Educação, Ciência e Tecnologia de Santa Catarina

Endereço: Rua 14 de julho

Bairro: Coqueiros

Cidade: Florianópolis

Número: 150

CEP: $88075-010$

CNPJ: $11.402 .887 / 0001-60$

Telefone(s): (48) 38778430

Ato Legal: Portaria $n^{\circ} 1490$ de 24 de agosto de 2006.

Endereço WEB: www.ifsc.edu.br

Diretora Geral: Nelda Plentz de Oliveira

\subsection{Nome do responsável/representante pelo projeto/oferta}

\begin{tabular}{|l|l|}
\hline \multicolumn{1}{|c|}{ Nome do responsável } & \multicolumn{1}{c|}{ Relação com o Curso } \\
\hline Luiz Cabral & Chefe do Departamento de Ensino, Pesquisa e Extensão \\
\hline Deosir Flávio Lobo de Castro Junior & $\begin{array}{l}\text { Membro do Núcleo Estruturante do Curso e } \\
\text { Coordenador do Curso Superior de Tecnologia em Gastronomia }\end{array}$ \\
\hline Nicole Pelaez & Membro do Núcleo Estruturante do Curso \\
\hline Vinícius De Luca Filho & Membro do Núcleo Estruturante do Curso \\
\hline
\end{tabular}

1.4 Contextualização da IES

O Instituto Federal de Educação, Ciência e Tecnologia de Santa Catarina (IF-SC) foi criado pela Lei no 11.892 de 29/12/2008. É uma Autarquia Federal, vinculada ao Ministério da Educação por meio da Secretaria da Educação Profissional e Tecnológica - SETEC, com CNPJ 11.402.887/0001-60, sediada em imóvel próprio, na Rua 14 de julho, 150, Enseada dos Marinheiros, Bairro Coqueiros, Florianópolis-SC. De acordo com a legislação de criação, a finalidade do IF-SC é formar e qualificar profissionais no âmbito da educação profissional técnica e tecnológica nos níveis fundamental, médio e superior, bem como ofertar cursos de profissional técnica e tecnológica nos níveis fundamental, médio e superior, bem como ofertar cursos de
licenciatura e de formação pedagógica, cursos de bacharelado e de pós-graduação lato e stricto sensu. Para licenciatura e de formação pedagógica, cursos de bacharelado e de pós-graduação lato e stricto sensu. Para
isso, a instituição atua em diferentes níveis e modalidades de ensino, oferecendo cursos voltados à educação isso, a instituição atua em diferentes níveis e modalidades de ensino, oferecendo cursos voltados à educação de jovens e adultos, de formação inicial e continuada, técnicos, de graduação e de pós-graduação. Assim, indivíduos capacitados para o exercício da cidadania e da profissão e tem como visão de futuro consolidarse como centro de excelência na educação profissional e tecnológica no Estado de Santa Catarina". Isso já e uma realidade, pois nos quatro últimos anos (dados de 2012) o IF-SC alcançou, com base no IGC, o melhor 
Centro Federal Universitário do país. Por meio do Ensino a Distância, o IF-SC ultrapassa os limites geográficos e oferece cursos técnicos, de graduação e pós-graduação em 33 polos de ensino em SC, RS, PR e SP. Nos últimos anos, em um processo de internacionalização, o IF-SC estabeleceu parcerias com instituiçõos de ensino estrangeiras para intercâmbio de alunos e servidores.

Em 2013 o IF-SC possuía 29.141 mil alunos e 933 docentes, em 21 campi distribuídos pelo estado de Santa Catarina, além da Reitoria, e está comprometido com a oferta de educação tecnológica em todos os níveis com a formação de educadores. Em 1909, quando a sociedade passava da era do trabalho artesanal para industrial, nascia em Florianópolis a Escola de Aprendizes Artífices, com o objetivo de proporcionar formação profissional aos filhos de classes socioeconômicas menos favorecidas. Ao longo dos anos, a instituição pass por sucessivas mudanças estruturais: Liceu Industrial de Florianópolis (1937); Escola Industrial de Florianópolis (1942): Escola Industrial Federal de Santa Catarina (1962): Escola Técnica Federal de Santa com a implantação de cursos de graduação tecnologica, de pós-graduçăo (especializaça) e a realização de pesquisa e de extensão. Em 29/12/2008, a Lei na 11 , então CEFET-SC decide pela transformação em Instituto Federal de Educação, Ciência e Tecnologia de Santa Catarina. Ampliam-se as ações e o compromisso com a inclusão social, investem-se mais recursos financeiros, amplia-se o quadro de pessoal, abrem-se novas oportunidades de acesso a programas de fomento à pesquisa, constitui-se um novo plano de carreira para os servidores, a autonomia financeira e didático-pedagógica se fortalece e assegura-se uma identidade para a Educação Profissional e Tecnológica. A instituição oferece educação profissional e tecnológica gratuita em todas as regiões de SC, contribuindo, assim, para o seu desenvolvimento socioeconômico e cultural. Consta nos objetivos da Instituição, contidos no PDI, "ministra em nível de educacão superior: a) cursos superiores de tecnologia visando à formacão de profissionais para c diferentes seloes da economia;b) cursos de licenciaura e programas especias de formaça pedagógica, com vistas à formação de professores para a educação básica, sobretudo nas áreas de ciências e física química, e para a educação profissional".

O Campus Florianópolis-Continente (CFC) surge em 2006, ainda como Unidade Continente do então CEFETSC. Além de ser a primeira escola federalizada no contexto de expansão da Rede Federal de educação profissional (federalização da Escola Catarinense de Gastronomia) o CFC é também o primeiro Campus exclusivamente voltado para o eixo tecnológico Turismo, Hospitalidade e Lazer (THL). Nesse sentido, destaca-se o pioneirismo da Instituição que, ao instalar essa unidade de ensino com sua oferta formativa baseada no referido eixo tecnológico, contribui para o fortalecimento da área, ainda em construção na Rede de Educação Profissional e Tecnológica.

A oferta de cursos gratuitos e de qualidade nesse eixo tecnológico é um marco, pela localização deste campus qualidade nesse ix m expressiva oferta de emprego nos diversos setores turísticos. Sua mportância não reside somente na necessidade de ofertar serviços turísticos de qualidade no âmbito do estado catarinense, mas também na missão de inserir o trabalhador melhor qualificado no mundo do trabalho.

A formação profissional no CFC está organizada em quatro itinerários formativos: Gastronomia, Eventos, Hotelaria e Turismo. Em cada itinerário, é disponibilizada ao público-alvo a continuidade de formação profissiona associada à elevação de escolaridade. Até hoje o Campus tem se dedicado, principalmente, à oferta de cursos Técnicos e de Formação Inicial e Continuada (FIC), consolidando a base do itinerário formativo.

Considerado hoje como ícone na formação profissional em Turismo, Hospitalidade e Lazer, o CFC tem se constituído em uma referência para o planejamento e implementação de novos cursos e laboratórios desse eixo na Rede Federal, contribuindo assim para o fortalecimento da atividade econômica do turismo no Brasi e para a melhoria na formação de profissionais para a área.

Seguindo a perspectiva de inclusão da classe trabalhadora, o CFC implementa ações que beneficiam o ingresso e a permanência do público alvo, como a aplicação de questionário socioeconômico para o ingresso nos cursos de qualificação, o acompanhamento pedagógico dos alunos e a assistência estudantil. Iniciativas como o Programa Nacional de Integração da Educação Profissional com a Educação Básica na Modalidad de Educação de Jovens e Adultos (PROEJA), realizado em parceria com municípios e com o Estado Catarinense; o Programa de Certificação Profissional e Formação Inicial e Continuada (CERTIFIC) para os perfis de auxiliar de cozinha, garçom, padeiro, camareira e guia de turismo; e a oferta de cursos em outros municípios - via extensão - busçondo padingir um público e guia de turismo; e a oferta de cursos em outros são também exemplos.

O Campus tem sido também palco para a construção de parcerias com atores da área de turismo e de evento como o Conselho Municipal de Turismo, o Grupo Gestor dos 65 Destinos Indutores de Turismo, a Via Gastronômica de Coqueiros, a Associação Comercial e Industrial de Florianópolis (ACIF); para a incubação da Associação de Condutores Ambientais e Culturais (UATAPI), construída nos moldes da economia solidária assim como para o intercâmbio com a França, através do estágio de professores e alunos dos itinerários de hotelaria, gastronomia e turismo dos dois países, e da recepção de alunos de intercâmbio canadenses.

Atualmente a escola conta com um efetivo que se 97 servidores, sendo 42 técnico-administrativos e 55 professores que atendem a um universo de mais de 1.000 alunos matriculados em cursos presenciais e distância. São ofertados os cursos técnicos subsequentes de Gastronomia, Panificação e Confeitaria, Guia de Turismo e Eventos, além de uma diversidade de cursos de Formação Inicial e Continuada (FIC), entre os quais: Condutor Cultural, Condutor Ambiental, Cerimonialista e Mestre de Cerimônia, Recepcionista de Eventos, Organização de Eventos Sociais, Operações Básicas em Cozinha, Operações Básicas em Panificação e Confeitaria; Serviços de Vinhos, Coquetelaria, Gestão de Empreendimentos em A e B, Espanhol para o Turismo, Inglês para o Turismo e LIBRAS.

O itinerário Hotelaria surgiu juntamente com o Campus, sendo o curso Técnico em Hospedagem o primeiro curso ofertado pelo CFC, em março de 2007. O itinerário Gastronomia iniciou em 2007, com densa oferta de cursos de FIC e de técnicos. Quanto aos cursos técnicos, o Campus ofertou ao longo da sua história diversas turmas dos cursos de Cozinha, de Serviços de Restaurante e Bar e de Panificação (transformado em 2009 turmas dos cursos de Cozinha, de Serviços de Restaurante e Bar e de Panificação (transformado em 2009,
com sucesso, em Panificação e Confeitaria). A partir do 20 semestre de 2012, o Campus passa a ofertar de com sucesso, em Panificação e Confeitaria). A partir do 2º semestre de 2012, o Campus passa a ofertar de
forma experimental o Curso Técnico em Gastronomia, que previa a junção dos Cursos de Cozinha e de Serforma experimental o Curso Técnico em Gastronomia, que previa a junção dos Cursos de Cozinha e de
viços de Restaurante e Bar, ampliando a formação e as possibilidades de áreas de atuação profissional.

Com relação à Formação Inicial e Continuada em gastronomia foram muitos os cursos já ofertados: Operações Básicas em Cozinha, Operações Básicas em Serviços de Restaurante e Bar, Operações Básicas em Panificação e Confeitaria, Confeitaria Artística, Coquetelaria, Serviços de Vinho, Cozinha Regional, Cozinha do Mar, Cozinha Saudável, Alimentação Escolar, Biscoitos, Salgadaria Básica, Hospitalidade Rural, Cozinha Serrana, Higiene e Manipulação de Alimentos, entre outros.

Cabe ressaltar que a inclusão de pessoas com necessidades específicas também está presente neste itine rário formativo. Cursos de FIC foram ofertados em parceria com a Fundação Catarinense de Educação Especial, com a APAE (Associação de Pais e Amigos dos Excepcionais) e com a APABB (Associação de Pais, Amigos e Pessoas com Deficiência, de Funcionários do Banco do Brasil e da Comunidade).

Destaca-se ainda a oferta de cursos PROEJA neste itinerário, totalizando doze turmas, em parceria com outras instituições de ensino. Seja integrando os anos finais do Ensino Fundamental com os cursos de FIC (Operações Básicas em Cozinha e Habilidades Básicas em Panificação e Confeitaria), seja integrando o Ensino Médio aos cursos técnicos (Cozinha, Serviços de Restaurante e Bar e Panificação e Confeitaria).

Ao longo de quase oito anos de sua intensa história o CFC consolida-se como referência no eixo THL, tendo percorrido uma trajetória que the permitiu gradativamente obter novas conquistas. A oferta inicial de cursos FIC e técnicos, sequencialmente, possibilitaram o fortalecimento do Campus de forma a atingir a maturidade necessária para a oferta de cursos superiores, em um processo gradual de verticalização, como é o caso do curso Superior de Tecnologia em Gastronomia proposto no presente projeto. 


\section{DADOS DO CURSO}

\subsection{Requisitos Legais}

A legislação educacional pertinente ao curso é a Lei 9.394 de 20 de dezembro de 1996 que estabelece as Diretrizes e Bases da Educação Nacional e nos termos do art. 71, $\S 1^{\circ}$ e $2^{\circ}$, do Decreto 5.773, de 2006 que dispõe sobre a adequação da denominação dos cursos superiores de tecnologia ao Catálogo Nacional de Cursos Superiores de Tecnologia.

O curso foi elaborado à luz do Catálogo Nacional de Cursos Superiores de Tecnologia do Ministério da Educação (MEC) que estabelece as Diretrizes Curriculares Nacionais para a Educação Profissional de Níve Tecnológico.

\subsection{Dados para preenchimento do diploma}

\begin{tabular}{|c|c|c|c|}
\hline Nome do Curso & Titulação & Legislação Específica & Carga Horária do Curso \\
\hline $\begin{array}{c}\text { Curso Superior de } \\
\text { Tecnologia em } \\
\text { Gastronomia }\end{array}$ & $\begin{array}{c}\text { Tecnólogo em } \\
\text { Gastronomia }\end{array}$ & Não se aplica & $\begin{array}{c}2.232 \text { horas } \\
\text { (incluindo } 252 \text { horas de estágio, } \\
108 \text { de TCC e Disciplina optativa) }\end{array}$ \\
\hline
\end{tabular}

\section{DADOS DA OFERTA}

3.1 Nome do curso

Curso Superior de Tecnologia em Gastronomia.

Presencial.

3.2 Modalidade

3.3 Eixo/Área

Turismo, Hospitalidade e Lazer, conforme Parecer CNE/CEB 03/2012.

3.4 Carga horária e Periodicidade

\begin{tabular}{|c|c|}
\hline Carga Horária & Periodicidade \\
\hline 2160 horas sem UC optativa & Anual \\
2232 horas com UC optativa & \\
\hline
\end{tabular}

3.5 Integralização

\begin{tabular}{|c|c|}
\hline $\begin{array}{c}\text { Prazo MINIMO para conclusão do } \\
\text { curso }\end{array}$ & $\begin{array}{c}\text { Prazo MÁXIMO para conclusão do } \\
\text { curso }\end{array}$ \\
\hline 6 (seis) semestres & $\begin{array}{c}\text { Até } 100 \% \text { (cem) além da carga total } \\
\text { do curso } \\
12 \text { (doze) semestres }\end{array}$ \\
\hline
\end{tabular}

3.6 Dados da oferta

\begin{tabular}{|c|c|c|c|}
\hline $\begin{array}{c}\text { Periodicidade da } \\
\text { Oferta }\end{array}$ & Turnos & $\begin{array}{c}\mathbf{N}^{\circ} \text { de Vagas discente } \\
\text { por turma }\end{array}$ & Total de Vagas Anuais \\
\hline Anual & Matutino & 40 (quarenta) & 40 (quarenta) \\
\hline
\end{tabular}




\section{ASPECTOS GERAIS DO PROJETO PEDAGÓGICO}

\subsection{Justificativa do curso}

Nas últimas duas décadas as atividades relacionadas ao turismo têm sido apontadas como estratégia viável e competitiva para o desenvolvimento econômico e sustentável do território brasileiro. Não por acaso, a missão institucional do Ministério do Turismo (MTur), criado em 2003, é justamente o de "desenvolver o turismo como uma atividade econômica sustentável, com papel relevante na geração de empregos e divisas, proporcionando a inclusão social" (BRASIL, 2011). Com o início das atividades do ministério, consolidando a atuação das secretarias municipais e estaduais de turismo, intensificou-se a demanda pelo planejamento do turismo através da iniciativa pública. Nesse contexto, cinco meses depois da criação do MTur, ocorreu a elaboração do Plano Nacional de Turismo (PNT 2003-2007), com o propósito de induzir o desenvolvimento e a inclusão social através da atividade. O plano foi vislumbrado como caminho para a consolidacão da "economia do turismo", pois trouxe a expectativa da abertura de novos postos de trabalho e a possibilidade de elevação do consumo e a consequente ampliação de renda em diferentes segmentos desse mercado (ALBAN, 2006; ROCHA \& ALMEIDA, 2008).

De maneira geral, pode-se afirmar que as ações ministeriais para a promoção da atividade atuaram em dois sentidos: primeiro com vistas a reconhecer, organizar e promover o turismo interno. Em outra direção, objetivou divulgar e reconstruir a imagem do Brasil no exterior, sobretudo das paisagens e dos diferentes atrativos que o país pode oferecer. Pode-se afirmar que a escolha do Brasil como sede para a Copa do Mundo de Futebol de 2014 e das Olimpíadas de 2016 foi o corolário da empreitada de pôr em evidência as "belezas" do território nacional no exterior. O euforismo político com a escolha do país como sede, para além de mero furor momentâneo, representou simbolicamente a transposição de uma imagem do Brasil como opção de turismo de segunda categoria para concebê-lo como possibilidade tanto para "vender" o território que estrangeiro desconhece, quanto para qualificar a forca de trabalho empregada pelos negócios do turismo. Em âmbito interno, o despontar do turismo brasileiro como estratégia de crescimento econômico implicou no reconhecimento

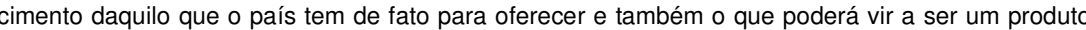
turístico. Nessa perspectiva é que se estabeleceram programas como os de regionalização do turismo, de qualificação dos equipamentos e serviços turísticos e de apoio à comercialização. Tais programas visaram aperfeiçoar $\mathrm{o}$ atendimento à demanda externa e interna, favorecida pelo relativo barateamento de passagen aéreas com o advento da concorrência no setor de aviação civil e pelos resultados das políticas econômica que permitiram, no Brasil, certa condição às classes populares de gastos com viagens a passeio ou de férias. O turismo corresponde, por sua vez, a uma das bases econômicas do município de Florianópolis. A cidade, promovida como "capital turística do Mercosul" e "llha da Magia", tem se projetado como um dos centros de maior visibilidade turística do sul do país. A campanha para internacionalização do turismo em Florianópolis, iniciada ainda na década de 1980 como parte do processo de expansão de divisas e "aspiração ao desenvolvimento", reflete atualmente uma conjuntura favorável no que se refere à colocação da cidade entre os principais destinos brasileiros (OLIVEIRA et. al., 2002). Convém ressaltar que sendo Florianópolis elencada pelo Ministério do Turismo como um dos três destinos indutores catarinenses para o fortalecimento da economia de serviços no país, a cidade vê-se comprometid com um o rol de requisitos necessários à certificação de qualidade para as atividades relacionadas ao segmento. Entre tais requisitos estão $o$ aperfeiçoamento da infraestrutura urbana que garantam a mobilidade e a segurança do visitante, bem como a qualificação dos serviços de alimentação e hospedagem, atividades diretamente relacionadas à recepção do turista.

Para atender a esses requisitos, ações conjuntas envolvendo diferentes segmentos de mercado e de instituições articuladas ao trade turístico têm se colocado como imprescindíveis, tendo em vista oferecer uma resposta satisfatória à promoção da atividade no município. Assim, devido ao êxito da divulgação turística da cidade tem se observado a expansão no número de estabecimentos de serviços de alimentaça a posição ocupada pela cidade em termos de fluxo de visitantes, não apenas no Brasil, como também no exterior.

A profissionalização dos trabalhadores e gestores nas atividades do turismo, por sua vez, é apontada como condição fundamental para o desenvolvimento do setor. Disso resulta a importância dos programas de educação que visam à qualificação do corpo técnico nele empregado tendo em vista que a qualificação técnica dos trabalhadores e gestores nas atividades do turismo está diretamente vinculada à melhoria do sistema de prestação de serviços e, por conseguinte, à satisfação dos clientes nos destinos (SANCHO, 2001).

Todavia, o mercado de trabalho de alimentação fora do lar, um dos principais segmentos do turismo, permanece sendo caracterizado pela escassa qualificação associada a contratos e condições de emprego es para os profissionais que atuan não é uma realidade apenas brasileira, mas observada também em demais países, entre os quais europeus. Segundo Sancho (2001), as condições desfavoráveis de emprego nos setores de hotelaria, alimentação, e do turismo em geral, repercute negativamente no setor, pois é responsável por produzir uma elevada taxa de abandono na mão de obra ocupada: "na Inglaterra calcula-se que aproximadamente $40 \%$ do pessoa abandona o emprego depois de um ano, enquanto na França, se constata que continua sendo um setor de passagem ou primeiro acesso para os jovens" (SANCHO, 2001: p. 353).

No Brasil, em 2005, os serviços de alimentação representavam cerca de 19,5\% do valor acumulado pelas atividades do turismo. Dentre às Atividades Características do Turismo (ACT), o segmento foi superado apenas pelos servicos de transporte rodoviário, que representavam aproximadamente $41.8 \%$ do valor apenas pelos sevir ao valor acumulado pelas ACT, superando segmentos como os de serviços de transporte aéreo, ferroviário metroviário, serviços de alojamento e as atividades de agências organizadoras de viagens (IBGE, 2008).

Por sua vez, o serviço de alimentação fora do lar foi o que mais se destacou em número de postos de trabalhos entre as ACT, sendo que em 2005 respondia por 37,79\% dos empregos, com 3066084 pessoas ocupadas. O segmento ocupava ainda a segunda posição na participação dos rendimentos pagos: 17,7\% entre as ACT ou seja, um montante de $\mathrm{R} \$ 9367$ milhões, com $31,27 \%$ dos trabalhadores com vínculo formal de emprego o que demonstra a relevância do setor na geração de empregos no país. A importância econômica dos negócios de serviços de alimentação, contudo, não é condizente do ponto de vista da qualificação profissional com o perfil dos trabalhadores e empresários envolvidos com tal atividade. Segundo dados da Pesquisa Nacional por Amostra de Domicílios (IBGE, 1999), o setor é significativamente carente de pessoas qualificadas, tanto no âmbito da gestão quanto dos demais funcionários dos empreendimentos de Alimentos e Bebidas.

Segundo a ABRASEL - Associação Brasileira de Bares e Restaurantes - existem no Brasil mais de um milhão Segundo a ABRASEL-Associação Brasileira de Bares e Restaurantes - existem no Brasil mais de um milhão
de empresas no segmento de alimentacão fora do lar, das quais cerca de $99 \%$ são micro e pequenas. Em de empresas no segmento de alimentação fora do lar, das quais cerca de $99 \%$ são micro e pequenas. Em
Santa Catarina, de acordo com o SEBRAE, em 2009 existiam cerca de 324 mil MPE, dessas 160 mil exercem Santa Catarina, de acordo com o SEBRAE, em 2009 existiam cerca de 324 mil MPE, dessas 160 mil exercem atividades comerciais. Dentre as atividades comerciais estão os estabelecimentos que atuam no segmento de alimentação fora do lar. Para Donato (2009) grande parte da população ativa, nos centros urbanos, realiza pelo menos uma de suas refeições diárias fora de seu domicílio, devido a motivos socioeconômicos, corporativos e culturais. Isso implica em um amplo mercado o segmento.

Em relação aos trabalhadores brasileiros, a PNAD (IBGE, 1999) revelou que aqueles que atuavam em bares e restaurantes, por exemplo, tinham média de idade de 35 anos, menos de sete anos de estudo, cumpriam jornadas de trabaho de 48 horas semanais e recebiam até 25 saĺrios mínimos. Tratava-se, portanto, de baixa escolaridade repercute em um mercado de mão de obra em serviços de alimentação pouco especializada, composta por trabalhadores que se sujeitavam a trabalhar por salário modestos e a cumprir jornadas além da regulamentada, de 44 horas semanais.

Quanto ao perfil dos gerentes e empresários, a pesquisa mostrou que a estrutura simples dos estabelecimentos no mercado brasileiro de bares e restaurantes repercutem em mais de $40 \%$ deles a concomitância de proprietários como funcionários nos negócios em que administram. Logo, proprietários gestores desses estabelecimentos devem ser considerados como potencial demanda para capacitação, não devendo às ações se restringir aos empregados. Por outro lado, não se descarta que mesmo em se tratando de empresários ou gestores que não executam atividades operacionais, a formação para a administração do negócio por meio de conhecimento sobre o mercado na área de alimentação é desejável.

Dessa forma, justifica-se a oferta do referido curso pelo Campus Florianópolis-Continente do IFSC, que atua no eixo tecnológico de Turismo, Hospitalidade e Lazer.

\subsection{Justificativa da oferta do curso}

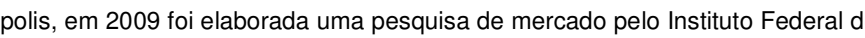
Santa Catarina - Campus Florianópolis Continente (IFSC-CFC), cujo objetivo foi identificar o perfil de escolaridade, qualificação técnica e intenção de qualificação dos profissionais que trabalham no setor de 
restaurantes, bares, lanchonetes, confeitarias e panificadoras. A amostra foi composta por 406 estabelecimentos nos quais foram aplicados 1516 questionários.

O estudo incluiu trabalhadores que desenvolviam atividades em diferentes níveis nos estabelecimentos, desde o operacional até a gestão. Os gestores dos estabelecimentos foram questionados quanto às dificuldades encontradas na gestão do negócio e os resultados encontrados estão demonstrados no Quadro

Quadro 1: Dificuldades na gestão apontadas pelos gestores de estabelecimentos na área de A\&B

\begin{tabular}{|l|l|l|}
\hline Dificuldades & O mais difícil & O mais difícil \\
\hline & Quantidade & $\%$ \\
\hline Gerenciamento da produção e/ou operações & 79 & $19,46 \%$ \\
\hline Gerenciamento das contas a pagar e receber & 77 & $18,97 \%$ \\
\hline Recrutamento e seleção & 70 & $17,24 \%$ \\
\hline Planejamento e controle de estoque & 52 & $12,81 \%$ \\
\hline Custos e preço de venda & 29 & $7,14 \%$ \\
\hline Atendimento ao cliente & 17 & $4,19 \%$ \\
\hline Relacionamento com os trabalhadores & 16 & $3,94 \%$ \\
\hline $\begin{array}{l}\text { Desenvolvimento de produtos/serviços } \\
\text { (inovação, adaptação) }\end{array}$ & 14 & $3,45 \%$ \\
\hline Treinamento da equipe & 13 & $3,20 \%$ \\
\hline Promoção de produtos/serviços & 12 & $2,96 \%$ \\
\hline Questões jurídicas & 11 & $2,71 \%$ \\
\hline Remuneração & 5 & $1,23 \%$ \\
\hline Tecnologia & 2 & $0,49 \%$ \\
\hline Outros & 1 & $0,25 \%$ \\
\hline Não responderam & 8 & $1,97 \%$ \\
\hline
\end{tabular}

No Quadro 1, observa-se que a primeira dificuldade apontada está relacionada à produção, isso significa que os gestores, muitas vezes, não são capacitados para a produção, o que indica que demandam formação nessa área. É possível destacar outras dificuldades apontadas, tais como: gerenciamento das contas a pagar e receber com $18,97 \%$, seguido por recrutamento e seleção com $17,24 \%$, planejamento e controle de estoque com $12,81 \%$ e custos e preço de venda com 7,14\%. Nesse contexto, são pertinentes programas de capacitação profissional para trabalhadores, gestores e proprietários envolvidos com o setor de alimentação fora do lar na área na Microrregião de Florianópolis, o que evidencia a necessidade de abertura do Curso de Tecnologia em Gastronomia que desenvolverá as competências para enfrentar às dificuldades apontadas. Cabe destacar que o turismo infuencia fortemente a economia local, além do que, a áca de almentos Cabe destacar que o urimentos bebidas possul um número expressivo de estabelecimentos. Segundo dados do Sindicato de Hotéis, Restaurantes, Bares e Similares de Flonlanópolis, o número aproximado de empresas na cidade, incluind bares, lanchonetes e restaurantes é de 1.843, dessas 756 são restaurantes. Considerando a região de Florianópolis, englobando: São José, Biguaçu, Palhoça, Governador Celso Ramos e Garopaba, o número total de estabelecimentos chega a 2.777. Vale lembrar ainda que a abertura de novos negócios no setor, muitas vezes, é feita sem planejamento o que leva, em diversos casos, ao fechamento do negócio. Portanto, é necessário estudar o setor, bem como as ferramentas para administrar o negócio, tendo em vista a sua sobrevivência. Diante do exposto, o IFSC-CFC, propõe o Curso Superior de Tecnologia em Gastronomia, de forma a contribuir para a formação profissional de qualidade e adequada às necessidades do mercado local e regional.

Por fim, cabe ressaltar com o advento das Olimpíadas Rio 2016, os egressos da primeira turma poderão atuar nos locais onde ocorrerão as atividades do evento.

\subsection{Objetivos do curso}

4.3.1 Objetivo Geral
Formar gestores de estabelecimentos de alimentos e bebidas com competência e habilidades para produzir, servir, planejar, empreender e gerir negócios na área de alimentos e bebidas com inovação e responsabilidade socioambiental.

\subsubsection{Objetivos Específicos}

Desenvolver capacidades para as funções de gestor, supervisor e coordenador da produção serviços de alimentos e bebidas, bem como para a execução de funções operacionais.

Formar e atualizar com novas tecnologias de trabalho, gestores, supervisores e coordenadores en gastronomia.

- Desenvolver as características profissionais para empreender e analisar o mercado da gastronomia. Formar trabalhadores para o gerenciamento dos problemas e criação de soluções, voltados para os resultados econômicos, financeiros e de satisfação dos clientes.

\subsection{Perfil Profissional do Egresso}

O Tecnólogo em Gastronomia concebe, planeja, gerencia, empreende e geri negócios na área de alimentos e bebidas com inovação, considerando aspectos culturais, econômicos e socioambientais. Além de operacionaliza produções culinárias, atuando nas diferentes fases dos serviços de alimentação.

\subsection{Competências profissionais}

- Gerenciar a abertura e a ampliação de negócios na área de alimentos e bebidas.

- Gerenciar as funções de marketing, recursos humanos, materiais, finanças e custos, na produção e nos serviços de alimentos e bebidas.

Produzir e servir alimentos e bebidas considerando os aspectos sensoriais, higiênico-sanitários, históricoculturais, nutricionais, físico-químicos, de segurança do trabalho e socioambiental.

- Compreender as questões científicas, técnicas, sociais, econômicas e culturais relacionadas a área de gastronomia.

Contribuir para a formação humanística, profissional e a sistematização dos saberes em gastronomia.

- Planejar, organizar, dirigir e controlar as atividades operacionais dos setores de produção e serviços em negócios de gastronomia.

- Aplicar as normas e procedimentos de higiene e segurança alimentar.

\section{6 Áreas de atuação}

Restaurantes comerciais, bares, cafés, empórios, bufês, refeições transportadas, catering, setores de alimentos e bebidas em meios de hospedagem e processamento artesanal de alimentos.

\subsection{Possíveis postos de trabalho}

Gerentes de estabelecimentos de gastronomia, gerente de alimentos e bebidas em meios de hospedagem, auxiliar de sala, auxiliar de bar, auxiliar de cozinha, cozinheiro, chefe de cozinha, garçom, maître d'hotel, barman.

\subsection{Ingresso ao curso}

Exame vestibular e/ou ENEM, de acordo com os critérios utilizados pelo DEING-IFSC. 


\section{ESTRUTURA CURRICULAR DO CURSO}

\subsection{Organização didático pedagógica}

O curso está organizado em regime de matrícula por componentes curriculares (disciplinas), composto por seis semestres de 360 horas, e atenderá ao disposto no Regulamento Didático Pedagógico - IFSC.

A normatização citada como Organização Didático-pedagógica (ODP) do Campus, documento que está sendo reestruturado e será unificado com a denominação de Regimento Didático-pedagógica (RDP).

O acadêmico que for aprovado em todas as disciplinas da fase deverá matricular-se nas disciplinas da próxima fase subsequente. Em caso de reprovação em alguma (s) disciplina(s), o estudante deverá privilegia a matrícula nas disciplinas pendentes (sempre que possível), e nas demais disciplinas que não possuam prerequisitos ou que já estão com as disciplinas que são pré-requisitos aprovadas, da próxima fase.

Sobre as disciplinas pendentes poderá o aluno se matricular, desde que se atenda as seguintes condições: i) disponibilidade de vagas da disciplina, ii) compatibilidade de horários entre as disciplinas pendentes, e os componentes curriculares da fase seguinte; iii) respeito aos pré-requisitos para a disciplina desejada.

O estágio obrigatório e o Trabalho de Conclusão de Curso serão ofertados no último semestre.

O curso será ministrado de segunda a sexta-feira, no período matutino, conforme edital de ingresso, sendo o horário matutino das 8:00h até 12:00h, conforme padrão atual do Campus. O horário previsto leva em conta a particularidade das aulas oferecidas em Cursos de Gastronomia por conter grande número de disciplinas com aulas práticas, as quais necessitam no mínimo 4 horas/aula para sua execução.

A formação do conhecimento passará pela integração da teoria e da prática em laboratório, além do estágio supervisionado obrigatório em estabelecimentos de alimentos e bebidas. A parte prática de cada disciplina será ministrada nos laboratórios didáticos do Campus Florianópolis-Continente.

\subsection{Articulação Ensino Pesquisa e Extensão}

A proposta pedagógica para o desenvolvimento da metodologia educacional das competências apresentadas nas disciplinas deve prever não só a articulação entre as bases técnicas, como também o desenvolvimento da competência de aplicação em busca de soluções tecnológicas envolvendo todas as disciplinas. Assim, a comunicação entre as disciplinas das fases deverão ocorrer continuamente.

Conforme a Lei de Diretrizes e Bases № 9.394/1996, no capítulo IV, art. 43: a educação superior tem por finalidade promover a extensão, aberta à participação da populacão, visando à difusão des conquistas benefícios resultantes da criação cultural e da pesquisa científica e tecnológica geradas na instituição.

O desenvolvimento das atividades de extensão ao longo do curso é de suma importância para que o alun steja em contato com o mercado de trabalho eutras entidades sociais relacionadas a sua área de atuação. As atividades de extensão serão realizadas ao longo do curso e garantidas por meio das visitas técnicas, seminários, contato com a área de atuação para desenvolvimento de soluções tecnológicas e inovadoras, e outras atividades.

O Curso Superior de Tecnologia em Gastronomia desenvolverá projetos técnicos científicos, podendo ser na forma interdisciplinar integrando as áreas do curso, incentivando os alunos à producão do conhecimento e a de outros programas de fomento à pesquisa e à extensão.

A pesquisa é uma ferramenta importante de complementação da formação ao longo do percurso escolar, pois auxilia o aluno na organização das ações embasadas em metodologia e rigor científico. A busca contínua de informações aprimora a habilidade do aluno de ter acesso rápido as informações utilizando diferentes ferramentas disponíveis em meio eletrônico e físico.
As ações de extensão objetivam a integração entre os alunos, a área profissional e a comunidade por meio do estabelecimento de parcerias. Na área da gastronomia é possível elencar alguns parceiros que possuem relacionamento com o campus Florianópolis-Continente, a saber: Associação Brasileira de Bares e Restaurantes, Associação Brasileira de Empresas de Eventos, Associação Catarinense dos Produtores de Vinhos Finos de Altitude, Associação Comercial e Industrial de Florianópolis, Associação dos Agricultores Ecológicos das Encostas de Serra Geral, Mesa Brasil SESC, Instituições de ensino internacional e empresas nacionais e internacionais.

A inter-relação entre o ensino a pesquisa e extensão contribui para uma formação completa, utilizando os conceitos teóricos para a aplicação direta com rigor científico, contribuindo para a eficiência e eficácia da formação.

\subsection{Metodologia}

As metodologias de ensino serão: aulas expositivo-dialogadas, atividades em laboratórios, trabalhos individuais e em grupos, debates, estudos de casos, seminários, painel integrado, ambientações profissionais, visitas técnicas, palestras, leituras de artigos, estágio curricular, trabalho de conclusão de curso, dentre outros.

5.4 Representação Gráfica do Perfil de Formação

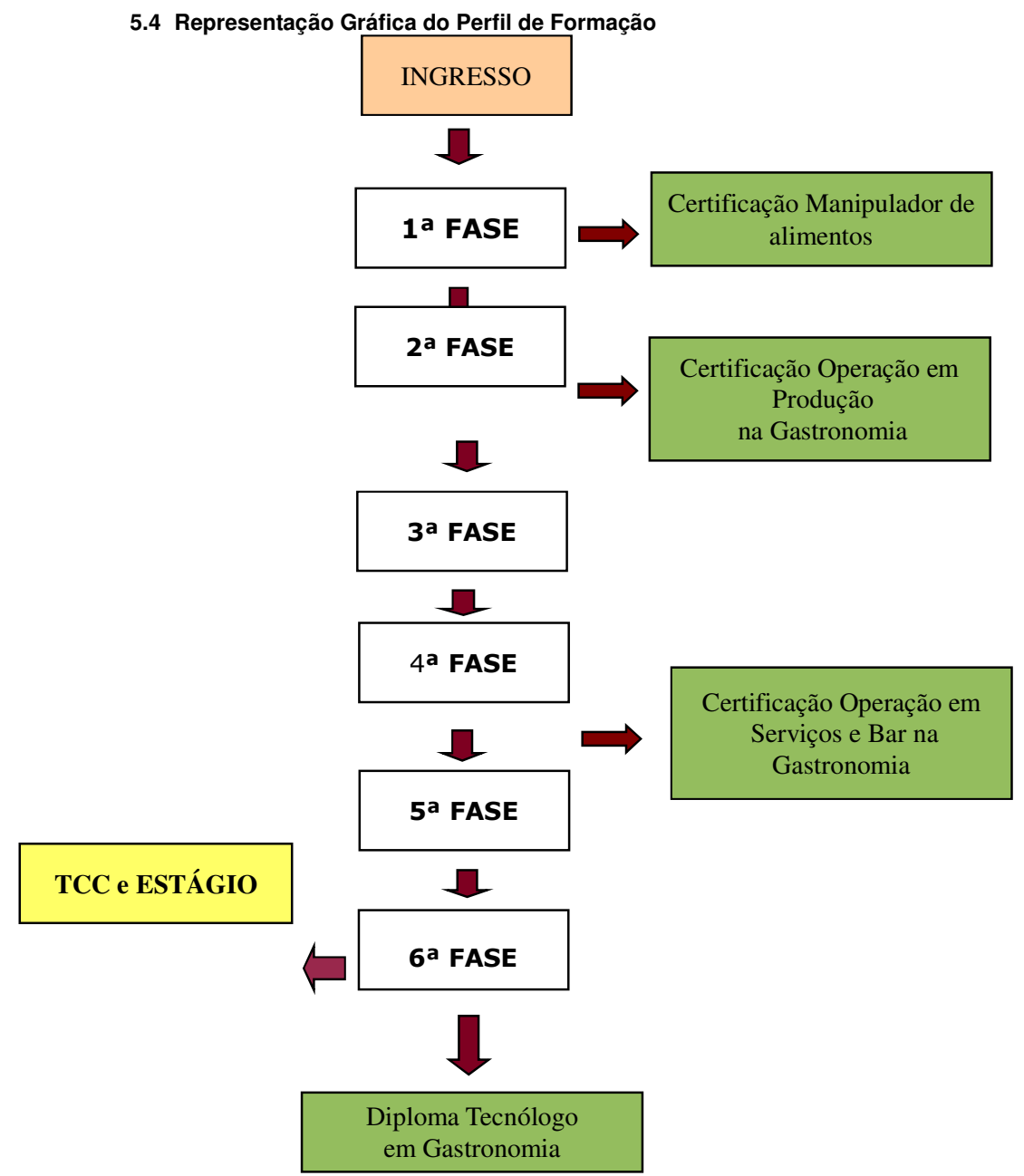


5.5 Matriz Curricular

A matriz curricular a seguir apresenta de forma resumida as disciplinas de cada fase, a carga horária teórica prática, bem como os pre-requisitos exigidos para o aluno se maticular na disciplina.

\begin{tabular}{|c|c|c|c|c|c|c|}
\hline EIXOS & $1^{\mathrm{a}}$ Fase & $2^{\mathrm{a}}$ Fase & 3a Fase & $4^{\mathrm{a}}$ Fase & $5^{\mathrm{a}}$ Fase & 6a Fase \\
\hline $\begin{array}{l}\text { Inovação } \\
\text { Tecnológica } \\
\text { Processamento } \\
\text { de alimentos }\end{array}$ & $\begin{array}{l}\text { Microbiologia } \\
\text { dos Alimentos } \\
\text { (36) }\end{array}$ & $\begin{array}{l}\text { Tecnologia de } \\
\text { Alimentos } \\
(72)\end{array}$ & $\begin{array}{l}\text { Análise } \\
\text { Sensorial } \\
(36)\end{array}$ & & & \\
\hline $\begin{array}{l}\text { Inovação } \\
\text { Tecnológica } \\
\text { Cultura, } \\
\text { Ambiente e } \\
\text { Alimentação }\end{array}$ & \begin{tabular}{|l} 
Turismo e \\
Hospitalidade \\
(72) \\
\\
\\
\end{tabular} & $\begin{array}{l}\text { Sociedade e } \\
\text { Trabalho } \\
\text { (36) } \\
\text { Gestão da } \\
\text { Sustentabilidad } \\
\text { e } \\
(36) \\
\\
\text { História da } \\
\text { Gastronomia } \\
\text { (36) }\end{array}$ & & & $\begin{array}{l}\text { Ecogastronomia } \\
\text { (36) }\end{array}$ & \\
\hline $\begin{array}{l}\text { Inovação } \\
\text { Tecnológica } \\
\text { Produção e } \\
\text { Serviços de } \\
\text { Alimentos } \\
\text { e Bebidas }\end{array}$ & $\begin{array}{l}\text { Habilidades } \\
\text { de Cozinha } 1 \\
\text { (72) }\end{array}$ & $\begin{array}{l}\text { Habilidades de } \\
\text { Cozinha } 2 \\
(72) \\
\\
\text { Panificação e } \\
\text { Confeitaria I } \\
(72)\end{array}$ & $\begin{array}{l}\text { Habilidades } \\
\text { de Cozinha } 3 \\
\text { (36) } \\
\text { Panificação e e } \\
\text { Confeitaria II } \\
\text { (72) } \\
\text { Nutrição e } \\
\text { Restrições } \\
\text { Alimentares } \\
\text { (72) }\end{array}$ & $\begin{array}{l}\text { Gastronomia } \\
\text { Clássica } \\
\text { (italiana, } \\
\text { francesa) } \\
(72) \\
\text { Gastronomia } \\
\text { Brasileira } \\
(72) \\
\\
\text { Bebidas e } \\
\text { Coquetelaria } \\
(72)\end{array}$ & $\begin{array}{l}\text { Gastronomia } \\
\text { Contemporânea } \\
\text { (36) } \\
\text { Gastronomia } \\
\text { Internacional } \\
(36) \\
\text { Enogastronomia } \\
\text { (72) } \\
\text { Serviços de } \\
\text { Restaurantes } \\
\text { (72) } \\
\text { Eventos em } \\
\text { Alimentos e } \\
\text { Bebidas } \\
\text { (36) } \\
\end{array}$ & \\
\hline $\begin{array}{l}\text { Inovação } \\
\text { Tecnológica } \\
\text { Segurança do } \\
\text { Trabalho e dos } \\
\text { Alimentos }\end{array}$ & $\begin{array}{c}\text { Segurança de } \\
\text { alimentos } \\
(36) \\
\text { Segurança do } \\
\text { Trabalho } \\
\text { (36) }\end{array}$ & & $\begin{array}{c}\text { Gestão da } \\
\text { segurança de } \\
\text { alimentos } \\
(36)\end{array}$ & & & \\
\hline
\end{tabular}

\begin{tabular}{|c|c|c|c|c|c|c|}
\hline $\begin{array}{l}\text { Inovação } \\
\text { Tecnológica } \\
\text { Gestão }\end{array}$ & $\begin{array}{l}\text { Introdução à } \\
\text { Administraçã } \\
\text { o (72) }\end{array}$ & \begin{tabular}{|l} 
Gestão de \\
Pessoas (36)
\end{tabular} & $\begin{array}{l}\text { Gestão } \\
\text { Financeira } \\
\text { (72) } \\
\text { Gestão de } \\
\text { Materiais (36) }\end{array}$ & $\begin{array}{l}\text { Gestão de } \\
\text { Custos } \\
(36) \\
\text { Gestão de } \\
\text { Marketing } \\
\text { (72) } \\
\text { Planejamento } \\
\text { de Cardápios } \\
\text { (36) }\end{array}$ & $\begin{array}{l}\text { Empreendedoris } \\
\text { mo } \\
(72)\end{array}$ & \\
\hline $\begin{array}{l}\text { Inovação } \\
\text { Tecnológica } \\
\text { Pesquisa e } \\
\text { Desenvolviment } \\
0\end{array}$ & $\begin{array}{l}\text { Fundamentos } \\
\text { do Trabalho } \\
\text { Acadêmico } \\
\text { (36) }\end{array}$ & & & & & $\begin{array}{l}\text { Trabalho de } \\
\text { Conclusão } \\
\text { de Curso } \\
(108) \\
\text { Estágio } \\
(252)\end{array}$ \\
\hline
\end{tabular}


Pré-requisitos:

\begin{tabular}{|c|c|c|}
\hline Fase & Disciplina & Pré-requisito \\
\hline $2^{\text {a }}$ Fase & Habilidades de Cozinha 2 & Habilidades de Cozinha 1 \\
\hline \multirow{3}{*}{ 3" Fase } & Habilidades de Cozinha 3 & $\begin{array}{l}\text { Habilidades de Cozinha } 1 \text { Segurança } \\
\text { de alimentos }\end{array}$ \\
\hline & Nutrição e Restrições Alimentares & $\begin{array}{l}\text { Habilidades de Cozinha } 1 \text { Segurança } \\
\text { de alimentos }\end{array}$ \\
\hline & Panificação e Confeitaria 2 & Panificação e Confeitaria 1 \\
\hline \multirow{3}{*}{ 4⿳亠丷a Fase } & Gastronomia Clássica & $\begin{array}{l}\text { Habilidades de Cozinha } 1 \text { Segurança } \\
\text { de alimentos }\end{array}$ \\
\hline & Gastronomia Brasileira & $\begin{array}{l}\text { Habilidades de Cozinha } 1 \text { Segurança } \\
\text { de alimentos }\end{array}$ \\
\hline & Gestão de Custos & Gestão Financeira \\
\hline \multirow[t]{2}{*}{$5^{\mathrm{a}}$ Fase } & Gastronomia Contemporânea & $\begin{array}{l}\text { Habilidades de Cozinha } 1 \text { Segurança } \\
\text { de alimentos }\end{array}$ \\
\hline & Gastronomia Internacional & $\begin{array}{l}\text { Habilidades de Cozinha } 1 \text { Segurança } \\
\text { de alimentos }\end{array}$ \\
\hline \multirow{2}{*}{ 6⿳ Fase } & Trabalho de Conclusão de Curso & $80 \%$ das Ucs (28 U.C.) \\
\hline & Estágio & $80 \%$ das Ucs (28 U.C.) \\
\hline
\end{tabular}

\subsection{Certificações Intermediárias}

aluno poderá ao final da $1^{\mathrm{a}}$ Fase, receber a certificação de Manipulador de Alimentos. Após conclusão $2^{\mathrm{a}}$ Fase, o aluno receberá certificação em Operação em Produção na Gastronomia, estando apto para exercer as funções de auxiliar de cozinha quente e fria. Concluindo a $5^{\text {a }}$ Fase o aluno receberá a certificação em Operação em Serviços e Bar na Gastronomia, estando apto para exercer as funções de auxiliar de sala, garçom, auxiliar de bar, barman e maître d'hotel.

\begin{tabular}{|l|l|}
\hline CERTIFICAÇÕES & COMPETÊNCIAS \\
\hline Certificação Manipulador de alimentos & $\begin{array}{l}\text { Aplicar as normas e procedimentos de higiene e } \\
\text { segurança alimentar. }\end{array}$ \\
\hline Operação em Produção na Gastronomia & $\begin{array}{l}\text { Produzir alimentos considerando os aspectos } \\
\text { higiênico-sanitários, histórico-culturais, de segurança } \\
\text { do trabalho e socioambiental. }\end{array}$ \\
\hline Operação em Serviços e Bar na Gastronomia, & $\begin{array}{l}\text { Servir alimentos e bebidas considerando os aspectos } \\
\text { sensoriais, higiênico-sanitários, } \\
\text { histórico-culturais, nutricionais, físico-químicos, de } \\
\text { segurança do trabalho e socioambiental. }\end{array}$ \\
\hline
\end{tabular}

\subsection{Componentes curriculares:}

\section{1' FASE}

Disciplina: MICROBIOLOGIA DOS ALIMENTOS

CARGA HORÁRIA: 36 HORAS

HABILIDADES:

- Identificar e utilizar critérios de qualidade de matérias-primas e fornecedores.

- Implantar e executar as boas práticas na produção de alimentos.

- Identificar e utilizar equipamentos e utensílios do setor de alimentos e bebidas com responsabilidade e segurança.

- Aplicar os princípios da ciência e tecnologia de alimentos na produção de alimentos e bebidas.

- Reconhecer e diferenciar os principais grupos de microrganismos relacionados à produção de alimentos e bebidas.

- Aplicar as boas práticas de produção e os procedimentos operacionais padronizados (POP). CONHECIMENTOS:

Tipos de micro-organimos

Segurança alimentar;

Métodos de conservação;

Coleta de amostras para análise;

Técnicas de deteccão dos micro-organismos.

\section{ATITUDES:}

Trabalhar em equipe.

Respeitar a comunidade escolar

Cumprir as tarefas solicitadas, respeitando os prazos.

Contribuir para as aulas com interesse e empenho.

Zelar pelo patrimônio escolar.

Demonstrar iniciativa nas aulas.

\section{BIBLIOGRAFIA BÁSICA:}

GERMANO, P.M.L.; GERMANO, M.I.S. Higiene e vigilância sanitária de alimentos. 4 ed. Manole, 2011. LACASSE, D. Introdução à microbiologia alimentar. Instituto Piaget, 1995.

TORTORA, G.J.; FUNKE, B.R.; CASE, C.L.Microbiologia. 8 ed. Artmed, 2008.

\section{COMPLEMENTAR:}

FUNKE, B.R.; CASE, C.L.; TORTORA, G.J. Microbiologia. 6.ed. Ed. Artmed. 2005.

FRANCO, B. D. G. M.; LANDGRAF, M. Microbiologia dos Alimentos, Editora Atheneu, 1996, 182p. (4a reimpressão)

RAY, N. Microbiologia de alimentos, $6^{2}$. ed. Porto Alegre: Art Med, 2005. 


\section{1ㄹ FASE}

Disciplina: TURISMO E HOSPITALIDADE

CARGA HORÁRIA: $72 h$

HABILIDADES:

- Identificar a gastronomia na cadeia produtiva do turismo.

- Reconhecer as atividades impulsoras do turismo, dos serviços de alimentação e do setor de hotelaria.

- Utilizar os conceitos de hospitalidade no âmbito da gastronomia.

- Compreender a gastronomia como atrativo turístico.

\section{CONHECIMENTOS}

Perspectiva histórica da hospitalidade.

Conceito e abrangência do turismo e da hospitalidade.

Cadeia produtiva do turismo.

Roteiros turísticos gastronômicos.

Evolução e características dos meios de hospedagem.

A hospitalidade nos serviços de alimentação.

Caracterização do setor de restauração.

\section{ATITUDES:}

Trabalhar em equipe.

Respeitar a comunidade escolar.

Cumprir as tarefas solicitadas, respeitando os prazos.

Contribuir para as aulas com interesse e empenho.

Zelar pelo patrimônio escolar.

Demonstrar iniciativa nas aulas.

\section{BIBLIOGRAFIA BÁSICA:}

CAMARGO. Luiz Octávio. Hospitalidade. São Paulo: Aleph, 2004.

LOCKWOOD, A; MEDLIK, S. Turismo e hospitalidade no século XXI. Barueri: Manole, 2003.

WALKER, John. R. Introdução à Hospitalidade. Barueri: Manole, 2002.

\section{COMPLEMENTAR:}

CAMPOS, José Ruy Veloso. Introdução ao Universo da Hospitalidade. São Paulo: Papirus, 2005. CASTELLI, Geraldo. Hospitalidade: na perspectiva da gastronomia e da hotelaria. São Paulo: Saraiva, 2005.

CHON, Kye-Sung \& SPARROWE, Raymond T. Hospitalidade: conceitos e aplicações. São Paulo: Pioneira-Thomson, 2003.

CAMPOS, José Ruy Veloso. Introdução ao universo da hospitalidade. Campinas, SP: Papirus, 2005. 218 p. (Hospitalidade). Bibliografia: p. [215]-218. ISBN 8530807847 (broch.).

\begin{tabular}{l} 
1a FASE \\
Disciplina: HABILIDADES DE COZINHA 1 \\
CARGA HORÁRIA: 72h \\
\hline HABILIDADES: \\
Selecionar e higienizar as matérias primas. \\
Utilizar adequadamente os utensílios e equipamentos. \\
Armazenar de forma adequada os alimentos. \\
Praticar as técnicas de preparação dos alimentos e as técnicas de base de cocção. \\
Aplicar tempos e métodos nos processos produtivos. \\
Aplicar corretamente os princípios de higiene pessoal, ambiental, de equipamentos, de utensílios e de \\
alimentos na produção de alimentos e/ou refeições. \\
\hline CONHECIMENTOS: \\
Brigada de cozinha. \\
Bases de cozinha. \\
Matérias primas. \\
Estrutura física e funcional de cozinha. \\
Corte e porcionamento de legumes e verduras. \\
Métodos de cocção. \\
Fundos, molhos e sopas. \\
Boas práticas de manipulação de alimentos. \\
Vocabulários técnicos de termos técnicos. \\
Fichas técnicas e espelhos de custo. \\
Formas corretas de aquisição, recebimento, armazenamento e conservação de alimentos. \\
Química aplicada aos alimentos. \\
\hline ATITUDES: \\
Trabalhar em equipe. \\
Respeitar a comunidade escolar. \\
Cumprir as tarefas solicitadas, respeitando os prazos. \\
Contribuir para as aulas com interesse e empenho. \\
Zelar pelo patrimônio escolar. \\
Demonstrar iniciativa nas aulas. \\
\hline BIBLIOGRAFIA BÁSICA: \\
CHEF PROFISSIONAL:Instituto Americano de Culinária.(tradução de Renata Lucia Bottini).São Paulo: Ed. \\
SENAC, 2009. \\
KÖVESI, Betty. 400G: Técnicas de cozinha.; llustrações de Dado Motta. São Paulo: Nacional, 2010. \\
THIS, Hervé.Um cientista na cozinha. 4. ed. São Paulo: Ática, 2006. \\
COMPLEMENTAR: \\
BRILLAT-SAVARIN, Jean-Anthelme.A fisiologia do gosto. São Paulo: Companhia das Letras, 1995. \\
DUMAS, Alexandre.Grande dicionário de culinária. Tradução de André Telles. Rio de Janeiro: Jorge \\
Zahar Editor, 2006. \\
JAMES, Kenneth. Escoffier: o rei dos chefs. Tradução de André Luiz Alvarenga. São Paulo: Ed. SENAC \\
São Paulo, 2008. \\
KLIE, Virginia.Glossário de gastronomia: português-inglês/ inglês-português. São Paulo: Disal, 2006. \\
LÉXICO científico-gastronômico: as chaves para entender a cozinha de hoje. São Paulo: Senac São Paulo, \\
2008. \\
\hline
\end{tabular}




\section{$1^{\text {a } F A S E}$}

Disciplina: SEGURANCCA DE ALIMENTOS

CARGA HORÁRIA: 36 HORAS

\section{HABILIDADES:}

Aplicar os princípios de higiene pessoal, ambiental, de equipamentos, de utensílios e de alimentos nos serviços de alimentação;

Selecionar adequadamente as matérias-primas:

Aplicar as técnicas de conservação de matérias-primas e de refeições.

CONHECIMENTOS:

Segurança alimentar

Importância da higiene alimentar

Conceito e aplicabilidade dos conceitos de Perigo, Risco, Severidade e Critério na produção de alimentos Microbiologia básica na manipulação dos alimentos

Doenças transmitidas por alimentos (DTAs)

Higiene pessoal

Higiene ambiental, de equipamentos e de utensílios

8. Higiene na produção de alimentos (seleção de fornecedores, recebimento, armazenamento, pré-preparo, preparo, espera; distribuição; sobras).

ATITUDES:

Trabalhar em equipe

Respeitar a comunidade escolar

Cumprir as tarefas solicitadas, respeitando os prazos.

Contribuir para as aulas com interesse e empenho.

Zelar pelo patrimônio escolar.

Demonstrar iniciativa nas aulas.

BIBLIOGRAFIA BÁSICA:

BRASIL. Ministério da Saúde. ANVISA. Portaria $n^{\circ}$. 1428 de 23/11/93. Disponível em: <http:// www.anvisa.gov.br>. Acesso em 14/02/14.

BRASIL. Ministério da Saúde. ANVISA. Resolucão RDC n ${ }^{\circ}$ 216, de 15 de setembro de 2004. Dispõe sobre Regulamento Técnico de Boas Práticas para Serviços de Alimentação. Disponível em www.anvisa.gov.br. Acesso em 14/02/06

JAY, J. M. Microbiologia de alimentos. 6 ed., São Paulo: Artmed, 2005.

\section{COMPLEMENTAR:}

LACASSE, D. Introdução a microbiologia alimentar. Lisboa: Instituto Piaget, 1995.

SANTA CATARINA. Decreto Estadual no. 31.455, de 20 de fevereiro de 1987. Estabelece critérios sobre estabelecimentos que manipulem, comercializem ou transportem alimentos e/ou bebidas. Disponíve em www.saudejoinville.sc.gov.br/visa/leiestadual.htm. Acesso em 04/04/07.

SILVA JUNIOR, E. A. Manual de Controle Higiênico-Sanitário dos Alimentos. $6^{a}$ edição, São Paulo: Varela, 2005, 624p.

ABERC. Associação Brasileira de Empresas de Refeições Coletivas. Manual ABERC de Práticas de Elaboração e Serviço de Refeições para Coletividades. 9aedição. São Paulo: ABERC, 2009. 211p.

BRASIL. Ministério da Saúde. ANVISA. Portaria SVS/MS n' ${ }^{\circ} 326$, de 30 de julho de 1997. Aprova regulamento técnico sobre as condições higiênico sanitárias e de boas práticas de fabricação para regulamento técnico sobre as condições higiênico sanitarias e de boas praticas de fabricação para
estabelecimentos produtores/industrializadores de alimentos. Disponível em www.anvisa.gov.br. estabelecimentos produ

Acesso em 17/07/2007.

BRASIL. Ministério da Saúde. ANVISA. Resolução RDC no. 12, de 2 de janeiro de 2001. Aprova Regulamento Técnico sobre Padrões Microbiológicos para alimentos. Disponível em www.anvisa.gov.br.

\section{$1^{\text {a }}$ FAS}

SEGURANCSA DO TRABALHO

CARGA HORÁRIA: $36 \mathrm{~h}$

\section{HABILIDADES}

Reconhecer os fatores de risco na operação da cozinha.

Prevenir possíveis acidentes na rotina de trabalho.

Verificar os controles de riscos ambientais.

Realizar técnicas de primeiros socorros.

\section{CONHECIMENTOS:}

Legislação;

O trabalhador e o ambiente de trabalho:

Equipamentos de prevenção individual e coletiva;

Identificação de riscos de acidentes no ambiente (físico, químico e biológico);

Causas de acidentes

Ergonomia;

Prevenção de acidentes:

Condições de trabalho;

Suporte básico de primeiros socorros.

\section{ATITUDES:}

Trabalhar em equipe.

Respeitar a comunidade escolar.

Cumprir as tarefas solicitadas, respeitando os prazos.

Contribuir para as aulas com interesse e empenho.

Zelar pelo patrimônio escolar.

Demonstrar iniciativa nas aulas.

BIBLIOGRAFIA BÁSICA:

CHIAVENATO, Idalberto. Gestão de pessoas: o novo papel dos recursos humanos nas organizações. ed. Rio de Janeiro: Elsevier, 2008.

SANTORO, Deyse. Conceição. Situações de Urgência \& Emergência: Manual de condutas práticas. Rio de Janeiro: Águia Dourada, 2011.

FIGUEIREDO, Luiza Guilherme Buchmann. Higiene e segurança do trabalho: livro didático. Palhoça: UnisulVirtual, 2007

\section{COMPLEMENTAR:}

MINISTÉRIO DO TRABALHO E EMPREGO M.T.E. Disponível em: <http://portal.mte.gov.br/portal-mte/> MORAES, Márcia Vilma Gonçalves de. Atendimento pré-hospitalar: treinamento da brigada de emergência do suporte básico ao avançado. 1 ed. São Paulo: látria, 2010.

MORAES, Márcia Vilma Gonçalves de. Doenças Ocupacionais - agentes: físico, químico, biológico, ergonômico. São Paulo: Érica, 2010.

QUILICI, Ana Paula; TIMERMAN, Sérgio. Suporte básico de vida: primeiro atendimento na emergência para profissionais de saúde. Barueri, São Paulo: Manole, 2011.

\section{1골}

Disciplina: INTRODUCCÃO A ADMINISTRAÇÃO

CARGA HORÁRIA: 72 HORAS 


\section{HABILIDADES}

Identificar e utilizar critérios das teorias para melhor o desempenho organizacional.

Desenvolver soluções na gestão de empreendimento na gastronomia, com base nas teorias administrativas e organizacionais.

Desenvolver visão sistêmica dos empreendimentos na área da gastronomia CONHECIMENTOS:

Principais teorias da administração: ideias fundamentais e tendências contemporâneas. Fundamentos e conceitos básicos da administração.

Processo administrativo e suas funções: planejamento, organização, direção e controle.

Processo decisório e resolução de problemas.

Identificar e utilizar critérios de das teorias para melhor o desempenho organizacional.

Identificar os conceitos básicos da Administração na realidade dos empreendimentos gastronômicos.

\section{ATITUDES:}

Trabalhar em equipe.

Respeitar a comunidade escolar.

Cumprir as tarefas solicitadas, respeitando os prazos.

Contribuir para as aulas com interesse e empenho.

Zelar pelo patrimônio escolar.

Demonstrar iniciativa nas aulas.

\section{BIBLIOGRAFIA BÁSICA:}

CASTELLI, G. Hospitalidade: na perspectiva da gastronomia hoteleira. São Paulo: Saraiva, 2005

CHIAVENATO, Idalberto. Teoria Geral da Administração. Rio de Janeiro: Elsevier, 2003.

SILVA, Reinaldo Oliveira. Teorias da administração. São Paulo: Pioneira Thomson Learning, 2001.

\section{COMPLEMENTAR:}

CASTELLI, G. Gestão hoteleira. São Paulo: Saraiva, 2006

CASTELLI, G. Administração hoteleira. Caxias do Sul: EDUCS, 2003

LACOMBE, J. M.; HEILBORN, Gilberto. Administração: princípios e tendências. São Paulo: Saraiva, 2003

MAXIMIANO Antonio Cesar Amaru. Introdução à Administração. São Paulo: Atlas, 2011.

\section{1글}

\section{Disciplina: FUNDAMENTOS DO TRABALHO ACADÊMICO}

CARGA HORARIA: 36 HORAS

HABILIDADES:

Desenvolver a habilidade teórico-metodológico necessário à elaboração de trabalhos acadêmicos

Desenvolver trabalhos e pesquisas com temas relacionados à tecnologia em gastronomia.

\section{CONHECIMENTOS}

Formas de conhecimento, ciência e pesquisa;

Aspectos do "estudar", "ler" e "escrever",

Estrutura básica do trabalho acadêmico: introdução, desenvolvimento e conclusão:

Tipos de trabalho acadêmico: resumo, resenha, relatório, artigo e monografia;

Tipos de pesquisa científica: empírica, bibliográfica, estudo de caso, qualitativa, quantitativa;

Estrutura básica do projeto de pesquisa;

Normatização de textos científicos: citações, referências e apresentação.

ATITUDES:

Trabalhar em equipe.

Respeitar a comunidade escolar.

Cumprir as tarefas solicitadas, respeitando os prazos.

Contribuir para as aulas com interesse e empenho.

Zelar pelo patrimônio escolar.

Demonstrar iniciativa nas aulas

\section{BIBLIOGRAFIA BÁSICA:}

ASSOCIAÇÃO BRASILEIRA DE NORMAS TÉCNICAS. NBR 10520 - Informação e documentação Citações em documentos - Apresentação. Rio de Janeiro: ABNT, ago. 2002a.

NBR 6023 - Informação e documentação - Referências - Elaboração. Rio de Janeiro: ABNT, ago. 2002b.

NBR 14724 - Informação e documentação - Trabalhos acadêmicos - apresentação. 2. ed Rio de Janeiro: ABNT, dez. 2005

\section{COMPLEMENTAR:}

GIL, Antônio Carlos. Como elaborar projetos de pesquisa. 5 ed. São Paulo: Atlas, 2010.

KOCHE, José Carlos. Fundamentos de metodologia científica: teoria da ciência e iniciação à pesquisa. 22. ed. Petrópolis, RJ: Vozes, 2004

DEMO, Pedro. Introdução à metodologia da ciência 2 ed São Paulo: Atlas, 1987. GALLIANO, Guilherme. O método científico: teoria e prática. São Paulo: Harba, 1985

GONSALVEZ, Eliza Pereira. Conversas sobre iniciação á pesquisa científica. $3^{\text {a }}$ ed.

Campinas, SP: Alínea, 2003.

GRESSLER, Lori Alice. Introdução à pesquisa: projetos e relatórios. São Paulo: Edições Loyola, 2003. JACOBINI, Maria Letícia de Paiva. Metodologia do trabalho acadêmico. $3^{a}$ ed. Campinas, SP: Alínea 2006

NORTHEDGE, Andrew. Técnicas para estudar com sucesso. Florianópolis: Ed. da UFSC/The Open University, 1998.

\section{2ㄱ FASE}

\section{Disciplina: TECNOLOGIA DE ALIMENTOS}

CARGA HORÁRIA: 72 HORAS

\section{HABILIDADES:}

- Identificar e utilizar critérios de qualidade de matérias-primas e fornecedores.

- Selecionar as matérias primas para produção de alimentos e bebidas.

- Preparar a mise-en-place da produção de alimentos e bebidas.

- Implantar e executar as boas práticas na produção de alimentos.

- Identificar e utilizar equipamentos e utensílios do setor de alimentos e bebidas com responsabilidade e segurança.

- Aplicar técnicas de pré-preparo, preparo, montagem e apresentação de alimentos e bebidas. 
CONHECIMENTOS

Química dos alimentos: carboidratos, proteínas, lipídios, água, vitaminas, sais minerais e pigmentos. Normas de laboratório.

Métodos de análise de alimentos.

Matérias primas de origem vegetal e animal.

Tecnologia de produtos de origem vegetal.

Tecnologia de produtos lácteos.

Tecnologia de produtos cárneos.

Métodos de conservação de alimentos: calor, frio, açúcar, sal, defumação, fermentação, irradiação, aditivos

\section{ATITUDES:}

-Trabalhar em equipe.

- Respeitar a comunidade escolar.

-Cumprir as tarefas solicitadas, respeitando os prazos.

- Contribuir para as aulas com interesse e empenho.

-Zelar pelo patrimônio escolar.

- Demonstrar iniciativa nas aulas.

BIBLIOGRAFIA BÁSICA:

ARAÚJO, W.M.C.; MONTEBELLO, N. di P.; BOTELHO, R.B.A.; BORGO, L.A. Alquimia dos alimentos Brasilia: Senac - DF, 2009

OETTERER, M.; REGITANO-D'ARCE, M.A.B.; SPOTO, M. H. F. Fundamentos de ciência e tecnologia de alimentos. Barueri: Manole, 2006.

THIS, H. Um cientista na cozinha. 4 ed. São Paulo: Ática, 2006.

\section{COMPLEMENTAR:}

FELOOWS, P.J. Tecnologia do Processamento de Alimentos - Princípios e Prática. 2 ed. Artmed. 2006. LOVATEL, J.L. Processamento de frutas e hortaliças. 1 ed. EDCS. 2004.

MACEDO, G.A.; Pastore, G. M.; Sato, H. H.; Park, Y. G. Bioquímica Experimental de Alimentos. 1 ed Editora Varela. 2005

RIBEIRO, E.P. Química dos alimentos. 2 ed. SP: Blucher, 2007.

MORETTI, C. Manual de Processamento Mínimo de Frutas e Hortaliças. Embrapa. 1 ed. 2007.

\section{2- FASE}

Disciplina: SOCIEDADE E TRABALHO

CARGA HORARIA: 36 HORAS

HABILIDADES:

- Analisar as situações de mercado relacionadas à formação e empregabilidade do gastrônomo no contexto regional, nacional e internacional.

- Analisar as variáveis econômicas e sociais envolvidas na expansão do mercado de Gastronomia no Brasil.

Avaliar as perspectivas da formação profissional em Gastronomia do ponto de vista científico e tecnológico.

\section{CONHECIMENTOS:}

- A formação em Gastronomia em outros países: o exemplo espanhol e francês.

- O interesse da indústria de alimentos na concepção de alimentação saudável: o caso da "gordura trans".

- O mercado de trabalho em Gastronomia e Turismo em Florianópolis: relato de egressos de cursos técnicos do IFSC.

- Perfil Profissional de Tralhadores, Proprietários e Gestores em Empresas de Alimentação Fora do Lar no

Litoral Central de Santa Catarina.

- A comida como símbolo e como mercadoria: perspectivas teóricas.

- O caráter artístico, científico, técnico e tecnológico da profissão Gastrônomo.

\section{ATITUDES}

-Trabalhar em equipe.

- Respeitar a comunidade escolar.

-Cumprir as tarefas solicitadas, respeitando os prazos.

- Contribuir para as aulas com interesse e empenho.

-Zelar pelo patrimônio escolar.

-Demonstrar iniciativa nas aulas.

BÁSICA:

CARNEIRO, H. Comida e Sociedade:uma história da alimentação. 6d. Rio de Janeiro: Campus, 2003, $185 p$

CHAUÍ, M. Convite à Filosofia. São Paulo: Ática, 2000. 440p.

ROCHA, Fernando G. Avaliação do Mercado de Trabalho em Turismo no Município de Florianópolis po Egressos de Cursos Técnicos. Campus Florianópolis-Continente: Educação profissional em Turismo com Responsabilidade Sociambiental.01 ed. Florianópolis: Publicações do IFSC, 2013, v.1, p.48-64.

\section{COMPLEMENTAR:}

BLAKE, A. , ARBACHE, J. S., SINCLAIR, M.T., TELES, V. K. Tourism and poverty relief. Textos para discussão. Escola de Economia de São Paulo da Fundação Getúlio Vargas, n. 237, 25p. São Paulo, out. 2009.

BOTTOMORE, T. B. DICIONARIO do pensamento marxista. Rio de Janeiro: Jorge Zahar, 2001.

DAMATTA, Roberto. O que faz o brasil, Brasil? Rio de Janeiro: Rocco, 1986.126p.

INSTITUTO BRASILEIRO Jaz o brasil, Brasil? Rio de Janeiro. Rocco, macroeconômica 2000-2005. Rio de Janeiro, IBGE, 2008.

\section{2- FASE}

\section{Disciplina: GESTÃO DA SUSTENTABILIDADE}

CARGA HORÁRIA: 36 HORAS

\section{HABILIDADES}

- Incorporar princípios de responsabilidade socioambiental na concepção e gerenciamento de negócios na área de alimentos e bebidas.

- Planejar e adotar medidas de gestão ambiental que possam melhorar o espaço de trabalho e reduzir o impacto da atividade sobre o meio ambiente em geral. 


\section{CONHECIMENTOS:}

Introdução à questão ambiental.

Dimensões e princípios da sustentabilidade.

Consumismo e meio ambiente.

Impactos ambientais ligados ao setor de alimentos e bebidas.

Medidas de racionalização do consumo de recursos e de redução e/ou destinação adequada dos

resíduos.

Sistemas de gestão, normatização e certificação ambiental.

ATITUDES:

Trabalhar em equipe.

Respeitar a comunidade escolar.

Cumprir as tarefas solicitadas, respeitando os prazos.

Contribuir para as aulas com interesse e empenho.

Zelar pelo patrimônio escolar.

Demonstrar iniciativa nas aulas.

\section{BIBLIOGRAFIA BÁSICA:}

DIAS, R. Gestão ambiental: responsabilidade social e sustentabilidade. São Paulo: Atlas, 2010. 196p. SEIFFERT, M.E.B. ISO 14001 - Sistemas de Gestão Ambiental: implantação objetiva e econômica. São Paulo: Atlas, 2009. 258p.

VILELA JÚNIOR, A. DEMAJOROVIC, J. Modelos e Ferramentas de Gestão Ambiental: desafios perspectivas para as organizações. São Paulo: SENAC, 2006. 396p

\section{COMPLEMENTAR:}

BALDISSARELLI, A. Considerando mais o lixo. Florianópolis: Copiart, 2009. 90p.

GIACOMINI FILHO, G. Consumismo e Meio Ambiente. São Paulo: SENAC, 2008. 254p.

MANO, E.B; PACHECO, E.B.; BONELLI,C.M.C. Meio Ambiente, poluição e reciclagem. Edgard Blucher, 2005. 182p.

PEREIRA, A. L. [et al.]. Logística reversa e sustentabilidade. São Paulo: Cengage Learning, 2012. 192p.

\section{2a FASE}

Disciplina: HISTÓRIA DA GASTRONOMIA

CARGA HORÁRIA: $36 \mathrm{~h}$

HABILIDADES

- Contextualizar as experiências gastronômicas às respectivas sociedades históricas delimitadas e os períodos históricos correspondentes.

- Relacionar as experiências gastronômicas com os respectivos modos de produzir e de organizar das sociedades humanas no tempo.

- Aplicar os conhecimentos históricos adquiridos em potenciais situações da vida prática profissional.

\section{CONHECIMENTOS:}

Experiências gastronômicas significativas na Pré-História, Antiguidade, Idade Média, Idade Moderna e Idade Contemporânea.

Experiências gastronômicas brasileiras nas perspectivas temporal e regional.

Brasil Colônia; Brasil Império; Brasil República.

Regiões Norte, Nordeste, Centro-Oeste; Sudeste; Sul.

Gastronomia catarinense.

ATITUDES:

Trabalhar em equipe.

Respeitar a comunidade escolar.

Cumprir as tarefas solicitadas, respeitando os prazos.

Contribuir para as aulas com interesse e empenho.

Zelar pelo patrimônio escolar.

Demonstrar iniciativa nas aulas.

BIBLIOGRAFIA BÁSICA:

CASCUDO, L. C. História da alimentação no Brasil. Global Editora, São Paulo, 2001. (6)

FLANDRIN, J.L. MONTANARI, M. A história da alimentação. Ed. Fayard, Paris,1996.

FRANCO, A. De caçador a Gourmet: uma história da gastronomia. São Paulo: Senac S.P, 2001.

\section{COMPLEMENTAR:}

CARVALHO, A.J. Cozinha típica brasileira. Ed. Ediouro, Rio de Janeiro, 1998

CHAVES, G.; FREIXA, D. Gastronomia no Brasil e no Mundo. $1^{\circ}$ ed. São Paulo, SP: SENAC, 2009.

LEAL, Maria Leonor de Macedo Soares. A História da Gastronomia. Rio de Janeiro. Editora Senac, 1998

FERNANDES, C . Viagem gastronômica através do Brasil. Senac, São Paulo, 2000

SIMÕES, A. O Pirão nosso de cada dia. Ed.Lunardelli. Florianópolis, 1999.

\section{2⿳亠口冋 FASE}

Disciplina: HABILIDADES DE COZINHA 2

CARGA HORÁRIA: $72 h$

Pré-requisito: Habilidades de Cozinha 1 e Segurança de alimentos

HABILIDADES:

- Selecionar e higienizar as matérias primas.

- Utilizar adequadamente os utensílios e equipamentos.

- Armazenar de forma adequada os alimentos.

- Praticar as técnicas de preparação dos alimentos e as técnicas de base de cocção.

- Aplicar tempos e métodos nos processos produtivos.

- Aplicar corretamente os princípios de higiene pessoal, ambiental, de equipamentos, de utensílios e de alimentos na produção de alimentos e/ou refeições.

\section{CONHECIMENTOS:}


Equipamentos e utensílios.

Corte e porcionamento de legumes, carnes, pescados e frutos do mar. Métodos de cocção.

Técnicas básicas de confeitaria.

Boas práticas de manipulação de alimentos.

Vocabulário básico de termos técnicos.

Formas corretas de aquisição, recebimento, armazenamento e conservação de alimentos.

\section{ATITUDES:}

Trabalhar em equipe

Respeitar a comunidade escolar.

Cumprir as tarefas solicitadas, respeitando os prazos.

Contribuir para as aulas com interesse e empenho.

Zelar pelo patrimônio escolar.

Demonstrar iniciativa nas aulas.

BIBLIOGRAFIA BÁSICA:

ARAÚJO, Wilma M. C. Alquimia dos alimentos. Brasília: Senac - DF, 2009

(12)

CHEF PROFISSIONAL:Instituto Americano de Culinária.(tradução de Renata Lucia Bottini).São Paulo:Editora SENAC, 2009

KÖVESI, Betty. 400G: Técnicas de cozinha.; llustrações de Dado Motta. São Paulo: Nacional, 2010.

\section{COMPLEMENTAR:}

ESCOFFIER, Auguste. Le guide culinaire: aide - mémoire de cusine pratique. França: Flammarion, 2009 JAMES, Kenneth. Escoffier: o rei dos chefs. Tradução de André Luiz Alvarenga. São Paulo: Ed. SENAC São Paulo, 2008.

BRILLAT-SAVARIN, Jean-Anthelme.A fisiologia do gosto. São Paulo: Companhia das Letras, 1995. HELENE, Helen. Dicionário de termos de Gastronomia: Francês/Português.Editora Boccato,2009.

STEINGARTEN, Jeffrey. O homem que comeu de tudo: feitos gastronômicos. Tradução de Henrique W. Leão. São Paulo: Companhia das Letras, 2000.

\section{2 $^{\mathrm{a}}$ FASE}

\section{Disciplina: PANIFICACÃO E CONFEITARIA 1}

CARGA HORÁRIA: 72 HORAS

\section{HABILIDADES:}

- Implantar e executar as boas práticas na elaboração de produtos de panificação e confeitaria básica. - Identificar e utilizar critérios de qualidade de matérias-primas e fornecedores.

- Selecionar as matérias primas do setor de panificação e confeitaria, considerando as características específicas de cada uma.

- Identificar e utilizar equipamentos e utensílios do setor de panificação e confeitaria com responsabilidade e segurança.

- Aplicar técnicas de pré-preparo, preparo, montagem e apresentação de produtos de panificação e confeitaria.

- Aplicar os princípios da ciência e tecnologia de alimentos na produção de produtos de panificação e confeitaria.

- Interpretar as fichas técnicas de produção e formulações de receitas.

- Preparar a mise-en-place dos produtos de panificação e confeitaria.

- Desenvolver técnicas de produção dos tipos de massas fermentadas, quebradiças, cremosas, aeradas, cozidas e líquidas.

\section{CONHECIMENTOS:}

Matérias primas, utensílios e equipamentos em conformidade com a legislação vigente.

Aspectos nutricionais.

Segurança do trabalho.

Higiene e manipulação.

Fluxograma, arranjo físico e manutenção.

Técnicas de produção: mistura, fermentação, batimento, modelagem, cocção e finalização de produtos.

Tipos de produtos na panificação e confeitaria.

Química dos alimentos.

ATITUDES:

Trabalhar em equipe.

Respeitar a comunidade escolar.

Cumprir as tarefas solicitadas, respeitando os prazos.

Contribuir para as aulas com interesse e empenho.

Zelar pelo patrimônio escolar.

Demonstrar iniciativa nas aulas

\section{BIBLIOGRAFIA BÁSICA:}

CANELLA-RAWL, S. Pão: arte e ciência. São Paulo: Editora Senac. 2005.(9)

GISSLEN, W. Panificação e confeitaria profissionais. 5 ed. São Paulo: Manole, 2011

SEBESS, P. Técnicas de padaria profissional. Senac, 2011.

\section{COMPLEMENTAR:}

BOSISIO, A. J. O pão na mesa brasileira. 2a.ed. Rio de Janeiro: Editora Senac Nacional. 2005

CAUVAIN, S.P.; YOUNG, L.S. Tecnologia da Panificação. 2a. ed. São Paulo: Editora Manole, 2009.

SEBESS, M. Técnicas de confeitaria profissional. 2 ed. Senac, 2009.

SUAS, M. Panificação e viennoiserie: abordagem profissional. Cengage Learning, 2012.

2 $^{\mathrm{a}}$ FASE

Disciplina: GESTÃO DE PESSOAS

CARGA HORÁRIA: 72 HORAS

\section{HABILIDADES:}

Identificar e reconhecer a importância dos recursos humanos na produtividade e qualidade do trabalho assim como as funções táticas e estratégicas nas organizações.

- Utilizar teorias relativas às organizações e ao comportamento das pessoas para gerir equipes de

trabalho, bem como relacionar-se no ambiente organizacional.

- Gerenciar os processos de agregar, aplicar, recompensar, desenvolver e manter pessoas nas empresas.

\section{CONHECIMENTOS:}

Organizações como sistemas sociais.

Pessoas como recursos $X$ Pessoas como parceiras da organização

- Mudanças na gestão de pessoas: do operacional para o estratégico

Novos Papéis na Gestão de Pessoas Funções de recursos humanos

Comunicação: comunicação humana; barreiras à comunicação; Janela de Johari e o relacionamento interpessoal e grupal.

Comportamento humano nas organizações: o homem complexo.

A função de Recursos Humanos e a estrutura organizacional. Terceirização.

Processos de gestão de pessoas:

-Processo de agregar: recrutamento e seleção de pessoas. 
Processo de aplicar: desenho de cargos; avaliação de desempenho.

Processo de recompensar: remuneração e benefícios.

Processo de desenvolver e manter: treinamento e desenvolvimento; administração de conflitos;

Qualidade de Vida no Trabalho (QVT).

ATITUDES:

Trabalhar em equipe.

Respeitar a comunidade escolar.

Cumprir as tarefas solicitadas, respeitando os prazos.

Contribuir para as aulas com interesse e empenho.

Zelar pelo patrimônio escolar.

Demonstrar iniciativa nas a

\section{BIBLIOGRAFIA BÁSICA:}

CHIAVENATO, Idalberto. Gestão de pessoas. Rio de Janeiro: Elsevier, 2009

LACOMBE, Francisco. Recursos humanos: princípios e tendências. São Paulo: Saraiva, 2011.

CHIAVENATO, Idalberto. Recursos Humanos: fundamentos básicos. São Paulo: Manole, 2009.

\section{COMPLEMENTAR}

MAXIMIANO Antonio Cesar Amaru. Introdução à Administração. São Paulo: Atlas, 2011.

GARCIA, Adriana Amadeu; ARAUJO, Luis Cesar G. de. Gestão de pessoas: edição compacta. São

Paulo: Atlas, 2010.

GIL, Antônio Carlos. Gestão de pessoas: enfoque nos papéis profissionais. São Paulo: Atlas, 2001.

TEIXEIRA, F. R. Gestão de pessoas. Florianópolis: CEFET, 2008 (5).

\section{$3^{\text {a }}$ Fase}

UNIDADE CURRICULAR: ANÁLISE SENSORIAL DE ALIMENTOS

CARGA HORÁRIA: 36 HORAS

\section{HABILIDADES:}

- Identificar e utilizar critérios de qualidade de matérias-primas e fornecedores.

- Selecionar as matérias primas para produção de alimentos e bebidas.

- Implantar e executar as boas práticas na produção de alimentos.

- Identificar e utilizar equipamentos e utensílios do setor de alimentos e bebidas com responsabilidade e segurança.

- Aplicar técnicas de pré-preparo, preparo, montagem e apresentação de alimentos e bebidas.

- Aplicar os princípios da ciência e tecnologia de alimentos na produção de alimentos e bebidas.

- Planejar e executar controles na área de produção.

- Perceber através dos órgãos dos sentidos humanos as características sensoriais de matérias primas e produções gastronômicas.

\section{CONHECIMENTOS:}

Introdução a análise sensorial de alimentos.

Conceito e aplicabilidade da análise sensorial.

Órgãos dos sentidos humanos.

Características sensoriais

Identificação das características de alimentos e bebidas.

Organização das equipes de julgadores de testes.

\begin{tabular}{l} 
Preparo de amostras. \\
Técnicas de análise sensorial. \\
\hline ATITUDES: \\
Trabalhar em equipe. \\
Respeitar a comunidade escolar. \\
Cumprir as tarefas solicitadas, respeitando os prazos. \\
Contribuir para as aulas com interesse e empenho. \\
Zelar pelo patrimônio escolar. \\
Demonstrar iniciativa nas aulas. \\
BIBLIOGRAFIA BÁSICA: \\
DUTCOSKY, S. D. Análise sensorial de alimentos. 2 ed. Curitiba: Champagnat, 2007. \\
ARAUJO, W.M.C.; MONTEBELLO, N.P; BOTELHO, R.B.B.; BORGO, L.A. Alquimia dos Alimentos. \\
2ed., Editora Senac, 2008. \\
COMPLEMENTAR: \\
ALMEIDA-SANTOS; DAMASIO, A.R.; HOUGH, S.; SILVA, M.V.; Avanços em Análise Sensorial. 1ed. \\
1999. \\
ANDRADE, E. Análise de alimentos. 3ed. 2009. \\
QUEIROS, M. I.; TREPTOW, R. O. Análise sensorial para avaliação da qualidade dos alimentos. Rio \\
Grande do Sul. Editora da FURG, 2006, 268 p. \\
ASSOCIAÇÃO BRASILEIRA DE NORMAS TÉCNICAS - ABNT. NBR 12994. Métodos de análise sensorial \\
de alimentos e bebidas. Classificação. São Paulo: ABNT, 1993. \\
FARIA, E. V. de; KATUME, Y. Técnicas de análise sensorial. Campinas, ITAL/LAFISE, 2002, 116 p.
\end{tabular}

de alimentos e bebidas. Classificação. São Paulo: ABNT, 1993.

FARIA, E. V. de; KATUME, Y. Técnicas de análise sensorial. Campinas, ITAL/LAFISE, 2002, 116 p.

\section{FASE}

Disciplina: HABILIDADES DE COZINHA 3

CARGA HORÁRIA: $36 \mathrm{~h}$

Pré-requisito: Habilidades de Cozinha 1 e Segurança de alimentos

HABILIDADES:

dentificação e critérios de qualidades para aves:

Cortes básicos aplicados a aves, desossas e porcionamentos

Formas de condimentação de aves:

Métodos de coç̧ão aplicáveis a aves: úmidos, secos e combinados;

Molhos básicos, derivados e contemporâneos aplicáveis ao produto;

Produções gastronômicas: frango, galeto, pato, perdiz e codorna.

\section{CONHECIMENTOS:}

Compreender e aplicar técnicas de preparo de aves como forma de desenvolvimento das habilidades básicas de cozinha.

Seguir as normas de higiene e inocuidade alimentar na manipulação de produtos cárneos;

Aplicar os conceitos de responsabilidade ambiental inerentes às práticas de cozinha.

Aplicar os conhecimentos básicos do gastrônomo o preparo correto de aves, uma vez que este produto é amplamente difundido na cultura alimentar nacional e mundial 


\section{Bases de cozinha.}

Matérias primas.

Equipamentos e utensílios.

Corte e porcionamento de legumes, carnes, pescados e frutos do mar.

Métodos de cocção.

Técnicas básicas de confeitaria

Boas práticas de manipulação de alimentos.

Vocabulário básico de termos técnicos.

Formas corretas de aquisição, recebimento, armazenamento e conservação de alimentos.

\section{ATITUDES:}

Trabalhar em equipe.

Respeitar a comunidade escolar.

Cumprir as tarefas solicitadas, respeitando os prazos.

Contribuir para as aulas com interesse e empenho.

Zelar pelo patrimônio escolar.

Demonstrar iniciativa nas aulas.

BIBLIOGRAFIA BÁSICA:

Chef profissional: Instituto Americano de Culinária. (tradução de Renata Lucia Bottini). São Paulo: Editora SENAC, 2009

Wright, J; Truille. Le cordon Bleu: Todas as técnicas culinárias. São Paulo: Marco Zero, 1997.

COMPLEMENTAR:

BARRETO, Ronaldo Lopes Ponte. Passaporte para o sabor. São Paulo: SENAC, 2003 SEBESS, Mariana G. Técnicas de cozinha profissional. $3^{\mathrm{a}}$ Ed. São Paulo: SENAC São Paulo, 2010. LAROUSSE. Le grand Larousse Gastronomique. Paris: Larousse, 2007. NETO, Nelson de Castro; LOPES, Thiago Henrique. Habilidades Básicas de Cozinha. Curitiba: Editora LT, 2011.

\section{$3^{\text {a }}$ Fase}

\section{Disciplina: PANIFICAÇ̃̃O E CONFEITARIA 2}

CARGA HORÁRIA: 72 HORAS

Pré- Requisito: Panificação e Confeitaria 1

$$
\text { HABILIDADES }
$$

- Implantar e executar as boas práticas na elaboração de produtos de panificação e confeitaria. - Identificar e utilizar critérios de qualidade de matérias-primas e fornecedores.

- Selecionar as matérias primas do setor de panificação e confeitaria, considerando as características específicas de cada uma.

- Identificar e utilizar equipamentos e utensílios do setor de panificação e confeitaria com responsabilidade e segurança.

- Identificar produções e interpretar fichas técnicas relacionadas à confeitaria.

- Aplicar os princípios da ciência e tecnologia de alimentos na produção de panificação e confeitaria.

- Preparar a mise-en-place dos produtos de panificação e confeitaria.

- Desenvolver técnicas de produção de massas cozidas, massas laminadas, merengadas e de sobremesas à base de mousses.

\section{CONHECIMENTOS}

Matérias primas, utensílios e equipamentos em conformidade com a legislação vigente;

Aspectos nutricionais;

Segurança do trabalho;

Higiene e manipulação;

Fluxograma, arranjo físico e manutenção;

Técnicas de produção: mistura, laminação, batimento, modelagem, cocção e finalização de produtos:

Tipos de produtos na panificação e confeitaria.

Quimica dos alimentos.

\section{ATITUDES:}

Trabalhar em equipe.

Respeitar a comunidade escolar.

Cumprir as tarefas solicitadas, respeitando os prazos.

Contribuir para as aulas com interesse e empenho.

Zelar pelo patrimônio escolar.

Demonstrar iniciativa nas aulas.

BIBLIOGRAFIA BÁSICA:

CANELLA-RAWL, S. Pão: arte e ciência. São Paulo: Editora Senac. 2005.

GISSLEN, W. Panificação e confeitaria profissionais. 5 ed. São Paulo: Manole, 2011.

SEBESS, P. Técnicas de padaria profissional. Senac, 2011

\section{COMPLEMENTAR:}

CAUVAIN, S.P.; YOUNG, L.S. Tecnologia da Panificação. 2a ${ }^{a}$. ed. São Paulo: Editora Manole, 2009. DUCHENE, L; JONES, B. Le Cordon Bleu: sobremesas e suas técnicas. Editora Marco Zero. 1ª.ed. 1999. SEBESS, M. Técnicas de confeitaria profissional. 2 ed. Senac, 2009.

SUAS, M. Panificação e viennoiserie: abordagem profissional. Cengage Learning, 2012.

\section{$3^{\text {a }}$ Fase}

\section{Disciplina:NUTRIĈ̃O E RESTRIÇÕES ALIMENTARES}

CARGA HORÁRIA: 72 HORAS

\section{HABILIDADES:}

- Identificar e preparar alimentos e bebidas nutricionalmente equilibrados.

- Identificar e preparar alimentos e bebidas adequados para pessoas com restrições alimentares.

\section{CONHECIMENTOS:}

Conceito e importância da alimentação saudáve

Guias e grupos alimentares

Micro e macronutrientes: funções e fontes alimentares

Aplicabilidades dos diferentes tipos de lipídios na gastronomia

Alimentos funcionais, antioxidantes e fitoquímicos: relevância na gastronomia.

Efeitos das principais técnicas de cocção sobre os alimentos.

Rotulagem Nutricional.

Alimentos diet e light: conceitos e aplicações práticas.

Tipos de edulcorantes e aplicabilidade.

Restrições alimentares:conceito, sintomas e evolução das doenças (diabetes mellitus; hipertensão arterial 
sistêmica; doença celíaca; obesidade; dislipidemia, intolerância à lactose, alergia alimentar).

Princípios da alimentação adequada e preparo de alimentos apropriados para pessoas com restrições alimentares.

\section{ATITUDES:}

Trabalhar em equipe.

Respeitar a comunidade escolar.

Cumprir as tarefas solicitadas, respeitando os prazos.

Contribuir para as aulas com interesse e empenho.

Zelar pelo patrimônio escolar.

Demonstrar iniciativa nas aulas

\section{BIBLIOGRAFIA BASICA:}

BRASIL. Ministério da Saúde. Secretaria e Atenção à Saúde. Coordenação Geral da Política de Alimentação e Nutrição. Guia Alimentar para a População Brasileira: promovendo a alimentação saudável. Brasília: Ministério da Saúde, 2006.

VI diretrizes brasileiras de Hipertensão. Revista Brasileira de hipertensão,v.17, n.1, jan./mar. 2010SOCIEDADEBRASILEIRADECARDIOLOGIA.DepartamentodeAterosclerose.

V Diretriz Brasileira De Dislipidemias e prevenção da aterosclerose. Arquivos Brasileiros Cardiologia, $v$. 101, n.4 (suplemento I), 2013.

Sociedade Brasileira de Diabetes. E-book: Diabetes na Prática Clínica. Módulo 3 - Tratamento do diabetes: abordagens educacionais e alterações no estilo de vida. Disponível em: www.diabetesebook.org.br

\section{COMPLEMENTAR:}

ORNELLAS, Lieselotte Hoeschl. Técnica dietética: seleção e preparo de alimentos. São Paulo: Athene 2001.

PHILIPPI, S. T. Nutrição e técnica dietética. 2.ed. São Paulo: Manole, 2006.

PHILIPPI, S. T. Pirâmide dos alimentos: fundamentos básicos da nutrição. São Paulo; Manole. 2008 SOCIEDADE BRASILEIRA DE DIABETES.Atualizações brasileiras sobre o diabetes. Rio de Janeiro: Diagraphic Editora, 2009

VALENZI, Margarida. Receitas com baixo colesterol. São Paulo: Marco zero, Protecor, 1998.

VALENZI, Margarida. Receitas leves para problemas digestivos. São Paulo: Marco Zero, 1998

VALENZI, Margarida. Receitas para diabéticos. São Paulo: Marco zero, ANAD, 1998.

SHERWOOD, Alice. Viva sem alergia. São Paulo: Publifolha, 2008.

LEÃO, L. S. C. de S.; GOMES, M. C. R. Manual de nutrição clínica: para atendimento ambulatorial do adulto. São Paulo: Vozes, 2009.

MARCHINI, J S; DUTRA DE OLIVEIRA, J.E. Ciências Nutricionais. São Paulo: Savier, 1998

ANGELIS, R. C. De; TIRAPEGUI, J. Fisiologia da nutrição humana: aspectos básicos aplicados funcionais. 2.ed. São Paulo: Atheneu, 2007.(6 cópias)

CUPPARI, L. Nutrição clínica no adulto. 2.ed. São Paulo: Manole

FARIAS, F. F.; FAGUNDES NETO, U. Intolerância aos carboidratos. The Electronic Journal of Pediatric Gastroenterology,Nutrition and Liver Diseases. Disponível em http://egastroped.com.br/dec04/intolerancia.htm, 04/05/08.on line, livre

MAHAN, L.K., ESCOTT-STUMP, S. Krause: Alimentos, Nutrição e Dietoterapia. 9.ed. São Paulo: Roca. 1998.

Sites:

Acelbra - Associação dos Celíacos do Brasil - www.acelbra.org.br

Vida sem Glúten e sem Alergias - www.vidasemglutenealergias.com 


\section{Fase}

Disciplina: GESTÃO DA SEGURANÇA DE ALIMENTOS

CARGA HORÁRIA: 36 HORAS

Pré-Requisito: Segurança de alimentos

\section{HABILIDADES:}

Reconhecer as exigências sanitárias para abertura de um Serviço de Alimentação

Elaborar os Procedimentos Operacionais Padronizados (POPs)

Elaborar Manual de Boas Práticas (MBP).

Identificar princípios básicos do Sistema APPCC nos serviços de alimentação.

\section{CONHECIMENTOS:}

Exigências sanitárias para abertura de um Serviço de Alimentação (edificação, alvará sanitário, treinamento / capacitações, atestados de saúde, etc).

Legislação sanitária vigente (federal, estadual e municipal).

Manual de Boas Práticas (MBP).

Procedimentos Operacionais Padronizados (POPs).

Análise de Perigos e Pontos Críticos de Controle (APPCC).

Sistemas de gestão na área de alimentos.

\section{ATITUDES:}

Trabalhar em equipe.

Respeitar a comunidade escolar.

Cumprir as tarefas solicitadas, respeitando os prazos.

Contribuir para as aulas com interesse e empenho.

Zelar pelo patrimônio escolar.

Demonstrar iniciativa nas aulas.

\section{BIBLIOGRAFIA BÁSICA:}

BRASIL. Ministério da Saúde. ANVISA. Portaria nº 1428 de 23/11/93. Disponível em www.anvisa.gov.br. Acesso em 14/02/06. on line, livre

BRASIL. Ministério da Saúde. ANVISA. Resolução RDC $n^{\circ}$. 216, de 15 de setembro de 2004. Dispõe sobre Regulamento Técnico de Boas Práticas para Serviços de Alimentação.Disponível em $<$ http://portal.anvisa.gov.br/wps/wcm/connect/4a3b680040bf8cdd8e5dbf1b0133649b/RESOLU\%C3\%87\% C3\%83O-RDC+N+216+DE+15+DE+SETEMBRO+DE+2004.pdf?MOD=AJPERES $>$ Acesso 04/06/2014

SANTA CATARINA. Decreto Estadual no. 31.455, de 20 de fevereiro de 1987. Estabelece critérios sobre estabelecimentos que manipulem, comercializem ou transportem alimentos e/ou bebidas. Disponive em <http://server03.pge.sc.gov.br/LegislacaoEstadual/1987/031455-005-0-1987-000.htm>. Acesso em $04 / 06 / 2014$.

\section{COMPLEMENTAR}

MANUAL de elementos de apoio para o Sistema APPCC. Rio de Janeiro: SENAC/DN, 2001. $282 p$. (Qualidade e Segurança Alimentar). Projeto APPCC Mesa. Convênio CNC/CNI/SEBRAE/ANVISA. Disponível em: <http://www.ead.sebrae.com.br/premios/BPSA/5/elementos-apoio-sistemaappcc.pdf>Acesso em 04/06/2014.

BRASIL. Lei ํo 6437, de 20 de agosto de 1977. Configura infrações à legislação sanitária federal, estabelece as sanções respectivas, e dá outras providências. Disponível em: <http://www.planalto.gov.br/ccivil 03/leis//6437.htm>Acesso em 05/06/2014.

BRASIL. Ministério da Saúde. ANVISA. Resolução RDC no. 12, de 2 de janeiro de 2001. Aprova Regulamento Técnico sobre Padrões Microbiológicos para alimentos.Disponíve em<http://portal.anvisa.gov.br/wps/wcm/connect/a47bab8047458b909541d53fbc4c6735/RDC_12_2001.p df?MOD=AJPERES>Acesso em 05/06/2014.on line, livre

FLORIANÓPOLIS. Lei complementar no239 de 10/08/06. Institui o código de vigilância em saúde, dispõe sobre normas relativas à saúde no município de Florianópolis, estabelece penalidades e dá outras providências. Disponível em <http://cm.jusbrasil.com.br/legislacao/1019895/lei-complementar-239 06>Acesso em 05/06/2014.on line, livre

FLORIANÓPOLIS. LEI № 5980, de 02/01/02.Dispõe sobre a obrigatoriedade de treinamento em higien de alimentos e dá outras providências. Disponível em http://www.jusbrasil.com.br/legislacao/992686/lei5980-02-florianopolis-0. on line, livre

FLORIANOPOLIS. Decreto no2064 de 28/10/03. Regulamenta a lei no 5980 de 02 de janeiro de 2002 . Disponível emhttp://www.cmf.sc.gov.br.on line, livre

SILVA JUNIOR, E. A. Manual de Controle Higiênico-Sanitário dos Alimentos.6ª edição, São Paulo: Varela, 2005, 624p

BRASIL. Ministério da Saúde ANVISA Portaria SVS/MS $\mathrm{n}^{\circ}$ 326, de 30 de julho de 1997. Aprova regulamento técnico sobre as condições higiênico sanitárias e de boas práticas de fabricação para estabelecimentos produtores/industrializadores de alimentos. Disponível em www.anvisa.gov.br. Acesso em 17/07/2007.on line, livre

Trabalhando com segurança na produção de alimentos. Rio de Janeiro: SENAI, 1999. 28p. (2 cópias). Organização Mundial do Turismo. Manual de qualidade, higiene e inocuidade dos alimentos no seto de turismo : guia de consulta para funcionários, planejadores, empresários e operadores de turismo. São Paulo: Roca, 2003. (3 cópias)

JAY, J. M. Microbiologia de alimentos. $6^{a}$ edição, São Paulo: Artmed, 2005.(3 cópias)

LACASSE, D. Introdução a microbiologia alimentar. Lisboa: Instituto Piaget, 1995.

\section{Fase}

Disciplina: GESTÃO FINANCEIRA

CARGA HORÁRIA: 72 HORAS

HABILIDADES:

Noções de planilhas eletrônicas.

Compreender cálculos que envolvam capitalização e descapitalização

Entender sistemas de amortização de empréstimos

Avaliar investimentos

Analisar viabilidade econômica para o negócio. 


\section{CONHECIMENTOS:}

Matemática Comercial.

Noções de planilhas eletrônicas e calculadora HP-12C.

Fluxo de caixa.

Juros e descontos: simples e compostos.

Anuidades.

Amortização.

Depreciação.

Introdução à análise de investimentos.

\section{ATITUDES:}

Trabalhar em equipe.

Respeitar a comunidade escolar.

Cumprir as tarefas solicitadas, respeitando os prazos.

Contribuir para as aulas com interesse e empenho.

Zelar pelo patrimônio escolar.

Demonstrar iniciativa nas aulas.

Bibliografia Básica

MOTTA, Alexandre. Matemática aplicada. IFSC, 2ª Ed. Florianópolis, 2010.

RAYMUNDO, Pedro José; FRANZIN, Narciso Américo. O valor do dinheiro no tempo: matemática comercial e financeira. $3^{\text {a }}$ Ed. Maringá: Clichetec, 2009. Comprar 8

\section{Bibliografia Complementa}

AZEVEDO, Gustavo Henrique Wanderley de. Seguros, matemática atuarial e financeira: uma abordagem introdutória.São Paulo: Saraiva, 2008.

GITMAN, L.J. Princípios de administração financeira. São Paulo: Harbra, 1997.

PUCCINI, Abelardo de Lima. Matemática financeira objetiva e aplicada. São Paulo: Saraiva, 2004.

\section{$3^{\text {a Fase }}$}

Disciplina: GESTÃO DE MATERIAIS

CARGA HORÁRIA: 36 HORAS

\section{HABILIDADES:}

Efetuar o planejamento, a organização e o controle de estoque

Planejar e realizar compras.

Operar ferramentas informatizadas de gestão em A\&B.

\section{CONHECIMENTOS:}

Introdução à Administração de Materiais: Conceitos principais; interfaces organizacionais; relevância e funções dos recursos materiais.

Classificação de Materiais

Tipos de Estoques. Políticas de estoques. Custo de estoque. Planejamento de Estoques. Análise de Estoques: indicadores (inventário, giro). Classificação ABC

Dimensionamento de estoques: estoque mínimo, estoque máximo e ponto de pedido.

Compras: Objetivos. Tipos de compras: reativas, pró-ativas. Operacionalização. Fontes de fornecimento. Cadastro de fornecedores. Estratégias.

Utilização de um software de gestão na área de A\&B, com enfoque em: estoques, custos e vendas.

\section{ATITUDES:}

Trabalhar em equipe.

Respeitar a comunidade escolar.

Cumprir as tarefas solicitadas, respeitando os prazos.

Contribuir para as aulas com interesse e empenho.

Zelar pelo patrimônio escolar.

Demonstrar iniciativa nas aulas.

\section{BIBLIOGRAFIA BÁSICA:}

DIAS, Marco Aurélio P.. Administração de materiais: princípios, conceitos e gestão. São Paulo: Atlas, 2008.

FONSECA, Marcelo Traldi. Tecnologias gerenciais de restaurantes. São Paulo: Senac, 2009.

VIANA. João José. Administração de materiais: um enfoque prático. São Paulo: Atlas, 2009.

COMPLEMENTAR:

MAGNEE, Henri. Administração simplificada para pequenos e médios restaurantes. São Paulo: Varela, 2005.

TORRE, F. de La. Administração hoteleira, parte I. : departamentos. São Paulo: Rocca, 2001.

ZANELLA, Luiz C.. Instalação e administração de restaurantes. São Paulo: Metha, 2007. 


\begin{tabular}{l} 
4ª FASE \\
Disciplina: GASTRONOMIA CLÁSSICA (ITALIANA E FRANCESA) \\
CARGA HORÁRIA: $72 h$ \\
Pré-requisito: Habilidades de Cozinha I e Segurança de alimentos \\
\hline HABILIDADES: \\
Praticar as técnicas de preparação dos alimentos e as técnicas de cocção da cozinha clássica. \\
Relacionar tempos, texturas e métodos aos processos produtivos; \\
Identificar e elaborar pratos da cozinha clássica internacional; \\
Identificar os sabores típicos de cada prato através da degustação; \\
Apresentar os pratos elaborados respeitando o contexto histórico-cultural; \\
Utilizar as matérias primas específicas de cada prato clássico das cozinhas italiana e francesa. \\
\hline CONHECIMENTOS: \\
Matérias primas; \\
Métodos de pré preparo e preparo de alimentos; \\
Conceitos da cozinha clássica; \\
História dos principais pratos e matérias primas da cozinha clássica internacional; \\
Noções de análise sensorial; \\
Estilos alimentares que possam caracterizar as várias culturas. \\
\hline ATITUDES: \\
Trabalhar em equipe. \\
Respeitar a comunidade escolar. \\
Cumprir as tarefas solicitadas, respeitando os prazos. \\
Contribuir para as aulas com interesse e empenho. \\
Zelar pelo patrimônio escolar. \\
Demonstrar iniciativa nas aulas. \\
BIBLIOGRAFIA BÁSICA: \\
DOMINÉ, A. Culinária, especialidades européias. Ed. Konemann, Colonia, Alemanha,2001. \\
FLANDRIN,J.L.MONTANARI,M. A História da Alimentação.Ed. Fayard,Paris,1996. \\
LANCELOTI,S. Cozinha Clássica. Arte Editora, São Paulo,1991. \\
comPLEMENTAR: \\
BOCUSE,P. A Cozinha de Paul Bocuse.Ed. Fayard, Paris,1996. \\
GOMENSORO, M. L. Pequeno dicionário da gastronomia. Rio de Janeiro: Ed. Objetiva,1999. \\
HAZAN, M. Fundamentos da cozinha italiana clássica. São Paulo: Martins Fontes,1997. \\
WILLIAN,A. Culinária ilustrada passo a passo: francesa.São Paulo: Publifolha.2000. \\
\hline
\end{tabular}

\section{$4^{\mathrm{a}}$ FASE}

Disciplina: GASTRONOMIA BRASILEIRA

CARGA HORÁRIA: 72h

Pré-requisito: Habilidades de Cozinha I e Segurança de alimentos

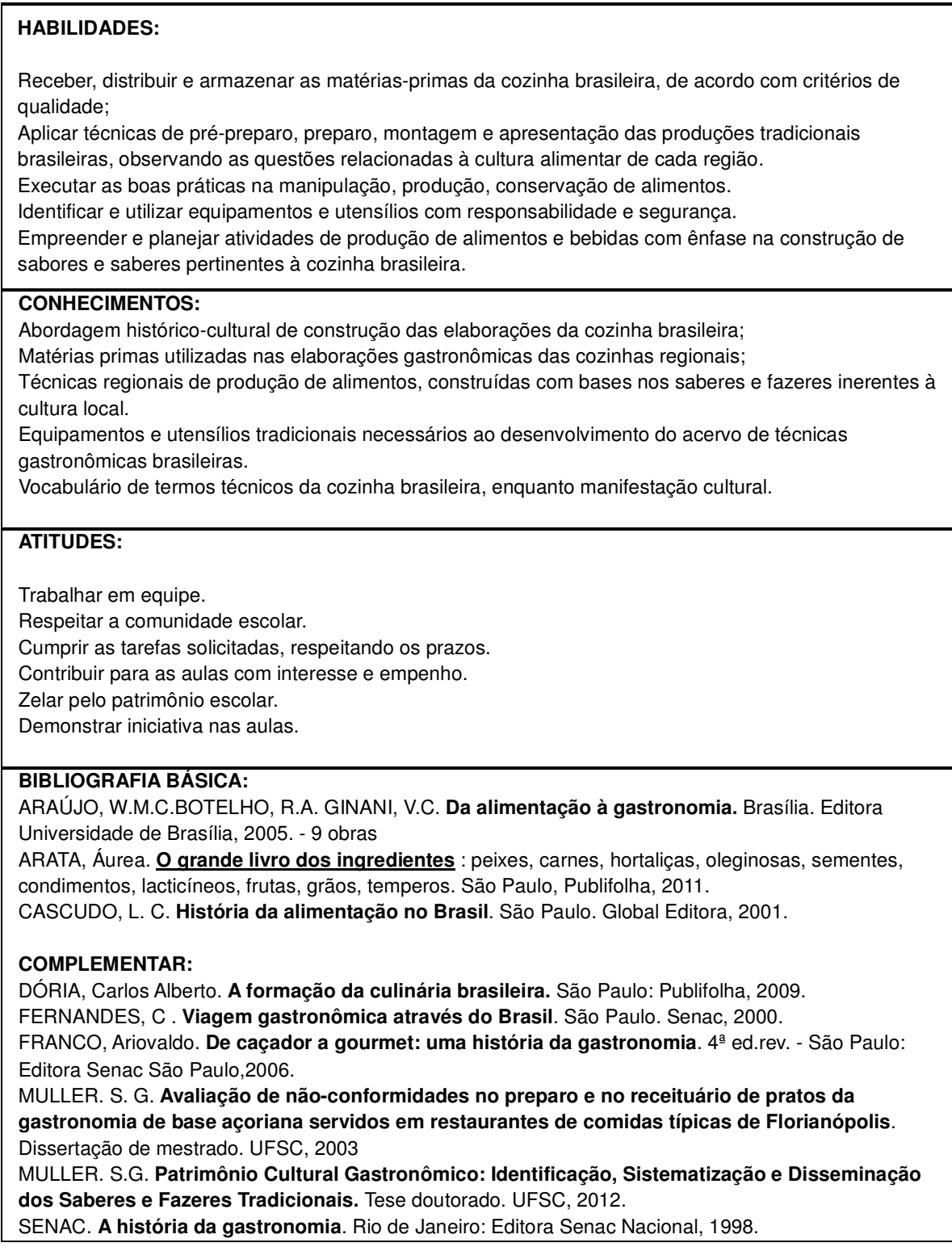

\section{4⿳亠口冋ASE}

Disciplina: BEBIDAS E COQUETELARIA

CARGA HORÁRIA: $72 \mathrm{~h}$ 


\section{HABILIDADES:}

Executar preparações básicas de bar.

Montar os espaços do bar e utilizar equipamentos e utensílios de serviços para o atendimento ao cliente. Conhecer os principais termos técnicos, para o serviço de bebidas.

Higienizar e polir os utensílios do bar.

Identificar os métodos de produção, preparar e servir o café e coquetéis à base de café.

Utilizar técnicas de serviço e harmonização de bebidas e alimentos.

Preparar coquetéis.

Organizar as fichas técnicas do setor.

Auxiliar na construção e comercialização da carta de bebidas.

Atender ao cliente.

Trabalhar em equipe.

\section{CONHECIMENTOS}

\section{Cargos e funções do bar.}

Mise-en-place do bar.

Tipologia de bar.

Origem e características dos diferentes tipos de bebidas não alcoólicas e alcoólicas.

Copos e utensílios em Coquetelaria.

Técnicas de elaboração de coquetéis e suas apresentações.

Harmonização de bebidas e alimentos.

Ficha Técnica.

Elaboração de carta de bebida.

\section{ATITUDES:}

Trabalhar em equipe

Respeitar a comunidade escolar.

Cumprir as tarefas solicitadas, respeitando os prazos.

Contribuir para as aulas com interesse empenho.

Zelar pelo patrimônio escolar.

Demonstrar iniciativa nas aulas.

\section{BIBLIOGRAFIA BÁSICA:}

FURTADO Edmundo. Copos de bar \& mesa: história, serviço, vinhos, coquetéis. São Paulo: Senac São Paulo, 2009.

GARCIA, Marina Petroff (tradução). Coquetéis: mais de 200 receitas para os melhores coquetéis! São Paulo: Marco Zero, 2011.

HAMLYN. 200 receitas de coquetéis inesquecíveis. São Paulo: Publifolha, 2011.

\section{COMPLEMENTAR:}

MORADO, Ronaldo. Larousse de cerveja. Larousse do Brasil, 2009

MURRAY, Jim MURRAY, Jim. O mundo do whisky: o mais completo guia internacional do whisky. São Paulo: Ática, 1997

PACHECO, Aristides de Oliveira. Manual do bar. 6ª Ed. São Paulo: Senac, 2005

PASCOAL, Luís Norberto. Aroma de café: guia prático para apreciadores de café. 2. ed. Campinas,

SP: Fundação Educar DPaschoal, 2006.
VALE, Janson. O mestre dos sucos : mais de 100 deliciosas receitas de sucos e vitaminas. São Paulo: Larousse do Brasil, 2008.

VENTURINI FILHO, Waldemar Gastoni. Tecnologia de Bebidas. EDGARD LUCHER, 2005. VIEIRA, SILVIA MARTA. BARMAN-Perfil Profissional, Tecnicas de Trabalho. Senac, 2009

ZIMMER, Susan. Eu amo café: mais de 100 bebidas com café deliciosas e fáceis de fazer. Tradução de Amini Rassoul, Fabiana Badra Eid. São Paulo: Prumo, 2009.

CÂNDIDO, Indio; VIERA, Elenara Vieira de. Maître d'hôtel: técnicas de serviço - 1. ed. Caxias do Sul: Educs, 2002.

DA CÂMARA TORRES, Marcelo Nóbrega. Cachaça, prazer brasileiro. Mauad Editora Ltda, 2004. MARQUES, J. Albano. Manual de Restaurante e Bar -1. ed. Rio de Janeiro: Thex Ed.,2002.

STANDAGE, Ton. História do mundo em 6 copos. São Paulo: Globo, 2005.

MELHORAMENTOS. 210 Coquetéis Essenciais - Um Brinde Aos Drinques Inesquecíveis! Editora Melhoramentos. 2011.

\section{4a FASE}

Disciplina: GESTÃO DE CUSTOS

CARGA HORÁRIA: 36 HORAS

Pré-requisito: Gestão Financeira

HABILIDADES

\section{Dimensionar gastos operacionais.}

Analisar custos fixos e variáveis.

Definir preço de venda para produtos.

Tomar decisões com base na apuração dos custos e demais gastos

Avaliar resultados de micro e pequenas empresas com registros em planilhas eletrônicas.

CONHECIMENTOS:

Introdução a custos: Gastos, custos, investimentos e despesas. Composição das receitas e dos custos. Critérios para custeio: custeio direto (variável) e custeio por absorção (rateio). Custos das mercadorias vendidas. Margem de contribuição.

vendidas. Margem de contribuição. da matéria-prima. Tributação. Gastos com pessoal. Custos fixos e variáveis, diretos e indiretos. da matéria-prinação.

Depreciação.

Formação de preços: Mark-up e margem de contribuição. Métodos empíricos.

Cálculo do ponto de equilíbrio.

Engenharia de cardápio.

Índices de desempenho: CMV, mão-de-obra e custo primário.

Análise da operação do negócio: tíquete médio, disponibilidade de assentos, rotatividade de assentos.

\section{ATITUDES:}

Trabalhar em equipe.

Respeitar a comunidade escolar.

Cumprir as tarefas solicitadas, respeitando os prazos.

Contribuir para as aulas com interesse e empenho.

Zelar pelo patrimônio escolar.

Demonstrar iniciativa nas aulas. 
BIBLIOGRAFIA BÁSICA

MAGNÉE, Henri Administração simplificada: para pequenos e médios restaurantes. São Paulo: Livraria Velera, 2005.

OLIVO, Ana Maria. Contabilidade Geral e Gerencial. Conceitos introdutórios para os cursos superiores de tecnologia. Florianópolis: Publicações do IFSC, 2012. (3 exemplares) e também disponíve no endereço:

http://www.ifsc.edu.br/images/pesquisa/livros_do_ifsc/miolos/Livro_contabilidade_miolo.pdf

ZANELLA, Luiz Carlos. Auditoria interna: rotinas e processos práticos para hotéis, restaurantes empresas em geral. Caxias do Sul: Educs, 2002.

\section{COMPLEMENTAR}

POWERS, Tom. Administração no setor de hospitalidade: turismo, hotelaria, restaurante. São Paulo: Atlas, 2004.

VAZ, Célio Silvério. Restaurantes: controlando custos e aumentando lucros. Brasilia: LGE Editada Ltda 2006.

\section{4" FASE}

\section{Disciplina: GESTÃO DE MARKETING}

CARGA HORÁRIA: 72 HORAS

HABILIDADES:

Analisar viabilidade mercadológica para o negócio.

Desenvolver ideias e identificar oportunidades de negócios.

Identificar a dimensão ambiental envolvida no processo de produção e consumo de alimentos.

Habilidades das funções administrativas.

Levantar e discutir questões sociais e da realidade contemporânea.

Criar soluções com flexibilidade, adaptabilidade e com inovação.

Selecionar estratégias adequadas de ação visando a atender interesses interpessoais e institucionais.

Propor modelos de gestão inovadores.

Decidir entre alternativas.

\section{CONHECIMENTOS}

Compreender o conceito científico do que é marketing;

Conhecer os conceitos centrais de marketing (necessidade, desejo, demanda, valor);

Identificar pelas ações e estratégias das organizações qual a sua orientação para o mercado (Produção, Produto, Vendas, Marketing e Marketing Societal);

Como monitorar o ambiente (concorrentes, político-legal, economia, ambiente ecológico, tecnologia consumidores e sociedade)

Compreender a segmentação, seus objetivos e vantagens, e seus critérios

Conhecer as opções estratégica de segmentação:

Conhecer o que é posicionamento e seu objetivo;

Conhecer as variáveis controláveis: Produto, Preço, Ponto de distribuição e Promoção e Propaganda:

Produto: Níveis, Classificação, Composto de Produto, análise da linha, análise da lucratividade da linha, Ampliação e Complementação da linha, modernização, expurgo e marca e embalagens:

Serviço: Conceitos, Características, Estratégias de Serviço, Qualidade e Produtividade;

Preço: Estabelecimento de Preço, Fatores de Estabelecimento de Preço e Adequação de Preço:

Distribuição: Maximizar as três utilidades (tempo, lugar e posse), tipos de distribuição (direta e indireta), níveis de distribuição $(0,1,2$ e 3$)$;

Composto Promocional: Identificação do público-alvo, objetivos da comunicação, desenvolvimento da mensagem, e características das ferramentas (Marketing Direto, Relações Públicas, Propaganda, Publicidade, Promoção de vendas, Merchandising, Venda Pessoal e Atendimento.

\section{ATITUDES:}

Trabalhar em equipe.

Respeitar a comunidade escolar.

Cumprir as tarefas solicitadas, respeitando os prazos.

Contribuir para as aulas com interesse e empenho.

Zelar pelo patrimônio escolar.

Demonstrar iniciativa nas aulas.

BIBLIOGRAFIA BÁSICA:

DIAS, Sérgio Roberto (Coord). Gestão de Marketing. São Paulo: Saraiva, 2003. (1)

KOTLER, Philip; KELEER, Kevin Lane. Administração de Marketing. 14a Ed. São Paulo: Pearson Prentice Hall, 2012.

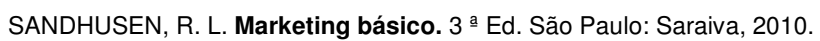

\section{COMPLEMENTAR:}

GARDANI, F. Gestão de Marketing na Hotelaria. São Paulo: Atlas, 2006.

MARICATO, P. Marketing para bares e restaurantes. Rio de Janeiro: Senac, 2009.

SOUKI, O. Paixão por marketing: o fantástico diferencial dos gênios. Belo Horizonte: Souki House, 2004.

TAVARES, P. V. Marketing fundamentos para a administração pública. Florianópolis: CEFET, 2008.

ZARDO, E. F. Marketing aplicado ao turismo: ferramentas de marketing para empresas de turismo e destinos turísticos. Rio de Janeiro: Roca, 2003. 


\section{4⿳亠口冋ASE}

Disciplina: PLANEJAMENTO DE CARDÁPIOS

CARGA HORÁRIA: 36

\section{HABILIDADES:}

Identificar público-alvo para diferentes tipos de restaurantes e eventos.

Auxiliar na escolha dos produtos que compõem o cardápio.

Descrever os produtos que compõem o cardápio.

Combinar preparações equilibrando e variando texturas, formas, cores, sabores e aromas.

Contribuir para a seleção de alimentos e bebidas mais adequados a diferentes tipos de restaurantes e eventos.

Descrever a carta de bebidas.

\section{CONHECIMENTOS:}

Conceitos básicos e tipologia de cardápios e menus.

Critérios a considerar para o planejamento de cardápios: público alvo, política de compras, cores, formas, sabores, aromas, texturas, sazonalidade, regionalidade, variabilidade, aceitação, estrutura física, recursos humanos, equilíbrio nutricional, tendências em gastronomia, tabus e modelos alimentares.

Sistematização das informações pertinentes aos cardápios e menus e precificação para as vendas.

Cardápios para restaurante com senviço de bufê comercial e à la carte.

Desenvolvimento do design do cardápio.

\section{ATITUDES}

Trabalhar em equipe.

Respeitar a comunidade escolar.

Cumprir as tarefas solicitadas, respeitando os prazos.

Contribuir para as aulas com interesse e empenho.

Zelar pelo patrimônio escolar.

Demonstrar iniciativa nas aulas.

\section{BIBLIOGRAFIA BÁSICA:}

BARRETO, Ronaldo. Passaporte para o sabor: tecnologias para elaboração de cardápios. 7 ed. São Paulo: SENAC, 2008.

TEICHMANN, I. Cardápios: técnicas e criatividade. Caxias do Sul: Educs, 2007

KNIGHT,J.B;KOTSCHEVAR,L.H.Gestão planejamento e operação de restaurantes. 3 ed.São Paulo

Roca, 2005

\section{COMPLEMENTAR:}

VASCONCELOS, F.; CAVALCANTE E.; BARBOSA L. Menu: como montar um cardápio eficiente. São Paulo: Roca, 2002.

FIGUEIREDO,A.A.Planejamento de cardápios para restaurantes.Gestão de Restaurantes,2011.

MEZOMO, I.B. Os serviços de alimentação. São Paulo: Manole, 2002. 5.ed.

WALKER, John. R.O restaurante: conceito e operação.Porto Alegre: Bookman, 2003

ZANELLA, L.C.Restaurante: técnicas e processos de administração e operação. Caxias do Sul:

EDUCS,2002.

\section{FASE}

Disciplina: ECOGASTRONOMIA

CARGA HORÁRIA: 36 HORAS

HABILIDADES:

Analisar criticamente a relação entre gastronomia, meio ambiente e produção de alimentos.

Reconhecer e promover a utilização de produtos alimentícios que apresentem responsabilidade socioambiental em sua cadeia produtiva.

\section{CONHECIMENTOS:}

Sustentabilidade na produção de alimentos. Agricultura moderna.

Impactos da cadeia produtiva de alimentos.

Agroecologia e agricultura sustentável.

Alimentos transgênicos e orgânicos.

Ética e bem estar animal.

Biodiversidade na produção de alimentos.

Etnobiologia da alimentação.

\section{ATITUDES:}

Trabalhar em equipe.

Respeitar a comunidade escolar.

Cumprir as tarefas solicitadas, respeitando os prazos.

Contribuir para as aulas com interesse e empenho.

Zelar pelo patrimônio escolar.

Demonstrar iniciativa nas aulas.

\section{BIBLIOGRAFIA BÁSICA:}

BARBIERI, R. L.; STUMPF, E. R. T. Origem e evolução das espécies cultivadas. Brasília: Embrapa, 2008. PETRINI, C. Slow food: princípios da nova gastronomia. São Paulo: Ed. SENAC São Paulo, 2009. 245p SMITH, J. M. Roleta genética: riscos documentados dos alimentos transgênicos sobre a saúde. São Paulo: João de Barro Editora, 2009. 305p. 909p.

\section{COMPLEMENTAR:}

BRASIL. MINISTÉRIO DA AGRICULTURA, PECUÁRIA E ABASTECIMENTO. Manual de hortaliças não convencionais. Brasília: MAPA/ACS, 2010. 92p. Disponível em: http://www.agricultura.gov.br/arq editor/file/vegetal/Qualidade/Qualidade\%20dos\%20Alimentos/manual\%2 http./Www.agricultura.gov.br/arq_editor/file/vegetal/Qualidade/Qualidade Ohortali\%C3\%A7as_WEB_F.pd

POLLAN, M. O dilema do onívoro: uma história natural de quatro refeições. Rio de Janeiro: Intrínseca, 2007. 479p

SINGER, P. Libertação animal. São Paulo: Lugano, 2004. 357p.

5. FASE

Disciplina: GASTRONOMIA CONTEMPORÂNEA

CARGA HORÁRIA: $36 \mathrm{~h}$

Pré-requisito: Habilidades de Cozinha 1 e Segurança de alimentos 


\section{HABILIDADES:}

Identificar a gastronomia contemporânea, do clássico ao moderno.

Conhecer e empregar técnicas culinárias características da cozinha contemporânea.

Conhecer e empregar diferentes estilos culinários e gastronômicos.

Empregar técnicas contemporâneas de apresentação nas preparações estudadas.

Analisar, selecionar e utilizar as matérias primas na elaboração de pratos da gastronomia contemporânea. Utilizar os conhecimentos e técnicas de habilidades básicas adquiridos na respectiva unidade curricular, nas preparações da gastronomia contemporânea.

\section{CONHECIMENTOS:}

Conceitos da gastronomia contemporânea

Características geográficas, históricas e culturais da gastronomia contemporânea.

Identificar receitas da cozinha contemporânea;

Redigir e interpretar fichas técnicas:

Desenvolver e produzir produções culinárias com base nas fichas técnicas

Matérias primas;

Principais equipamentos e utensílios:

Química básica dos alimentos;

Vocabulário básico de termos técnicos.

\section{ATITUDES:}

Trabalhar em equipe.

Respeitar a comunidade escolar.

Cumprir as tarefas solicitadas, respeitando os prazos.

Contribuir para as aulas com interesse e empenho.

Zelar pelo patrimônio escolar.

Demonstrar iniciativa nas

\section{BIBLIOGRAFIA BÁSICA:}

LÉXICO científico-gastronômico: as chaves para entender a cozinha de hoje. São Paulo: Senac São Paulo, 2008. -6 exemplares.

MCGEE, Harold. Comida \& cozinha: ciência e cultura da culinária. São Paulo: WMF Martins Fontes, 2011.

SANTAMARIA, S. A cozinha nu: uma visão renovadora do mundo da gastronomia. São Paulo: Senac São Paulo, 2009.

\section{COMPLEMENTAR:}

SEN, M. Luzes e sombras do reinado de Ferran Adrià. Tradução de Sandra Trabucco Valenzuela. São Paulo: Senac São Paulo, 2009.

ADRIÁ, Ferran; SOLER, Julia; ADRIÁ, Albert. El Bulli 2005. Espanha: Rba Libros, 2006.

BLUMENTHAL, H. The big fat duck cookbook. London: Bloomsbury, 2008.

KELLER, Thomas. Under pressure: cooking sous vide. New York: Artisan, 2008.

THIS, H.; MONCHICOURT, M-O. Herança culinária e as bases da gastronomia molecular. Tradução de Constacia Egrejas. São Paulo: Senac São Paulo, 2009.

SOU cozinheiro: técnicas, informações, tendências, aprimoramento profissional. Rio de Janeiro: Senac Nacional, 2012.

5 FASE

\section{Disciplina: GASTRONOMIA INTERNACIONAL}

CARGA HORÁRIA: $36 \mathrm{~h}$

Pré-requisito: Habilidades de Cozinha 1 e Segurança de alimentos

\section{HABILIDADES:}

- Identificar a gastronomia Asiática, das Américas, do Oriente Médio e outras cozinhas Europeias. - Empregar técnicas culinárias características das regiões abordadas.

- Relacionar os principais ingredientes e pratos típicos encontrados em cada região.

- Analisar, selecionar e utilizar as matérias primas na elaboração de pratos da gastronomia internacional.

- Utilizar os conhecimentos e técnicas de habilidades básicas adquiridos na respectiva unidade curricula nas preparações da cozinha internacional.

Ordenar as atividades à serem realizadas nas aulas.

\section{CONHECIMENTOS:}

Gastronomia Asiática.

Gastronomia das Américas.

Gastronomia do Oriente Médio.

Gastronomia de outras cozinhas Europeias.

Principais utensílios específicos das regiões observadas.

Utensílios utilizados nas regiões estudadas.

Características geográficas, históricas e culturais da gastronomia internacional.

ATITUDES:

Trabalhar em equipe.

Respeitar a comunidade escolar.

Cumprir as tarefas solicitadas, respeitando os prazos.

Contribuir para as aulas com interesse e empenho.

Zelar pelo patrimônio escolar.

Demonstrar iniciativa nas aulas.

\section{BIBLIOGRAFIA BÁSICA:}

ALFARO, M. S. Gastronomía latinoamericana. [S.I.]: Edelsa, 2005.

BELLUZZO, R. Os Sabores da América: Cuba, Jamaica, Martinica e México. São Paulo: SENAC-SP, 2004

CWIERTKA, K. J. Moderna Cozinha Japonesa - Comida, Poder e Identidade Nacional. São Paulo: SENAC, 2008.

\section{COMPLEMENTAR:}

DOMINÉ, A. Culinária, especialidades europeias: Colônia. Alemanha: Konemann, 2001. NEPOMUCENO, R. Viagem ao fabuloso mundo das especiarias: histórias e lendas, origens e caminhos, personagens, remédios, favores e sabores. 2. ed. Rio de Janeiro: José Olympio, 2003.

RAMOS A., MORAES M. Beirute: aromas, amores e sabores. Brasília: Senac - DF, 2004.

WALDMAN, M. Cozinha espanhola. São Paulo: Melhoramentos, 2005.

KASUKO, E. Culinária japonesa: receitas especiais fáceis de fazer. São Paulo: Publifolha, 2010.

BOURDAIN, A. Em busca do prato perfeito: um cozinheiro em viagem. 2. ed. São Paulo: Companhia das

Letras, 2009. 


\section{FASE}

Disciplina: ENOGASTRONOMIA

CARGA HORÁRIA: $72 \mathrm{~h}$

HABILIDADES:

Identificar as regiões produtoras de vinho no Brasil e no Mundo.

Apresentar e servir o vinho.

Utilizar os copos adequados para servir o vinho.

Higienizar e polir os copos de vinho.

Organizar a mise-en-place de mesa para o serviço de vinhos.

Planejar e controlar o estoque de vinhos.

Planejar a carta de vinhos.

Harmonizar comidas e vinhos.

Orientar sua equpe emireãa a venda do vinto.

\section{CONHECIMENTOS:}

Técnicas de degustação de vinhos.

A videira, tipos de uvas.

Métodos de elaboração dos vinhos.

Diferentes regiões produtoras de vinhos no mundo.

Harmonização de vinho e comida.

Elaboração de carta de vinhos.

Atendimento dos clientes nas mesas.

Venda de vinhos aos clientes.

Utilização de copos adequados aos vinhos.

Sistemas de informações e controle.

\section{ATITUDES:}

Trabalhar em equipe

Respeitar a comunidade escolar.

Cumprir as tarefas solicitadas, respeitando os prazos.

Cumprir as tareas solicitadas, respeitando os prazos.

Zelar pelo patrimônio escolar.

Demonstrar iniciativa nas aulas.

\section{BIBLIOGRAFIA BÁSICA:}

BORGES, Euclides Penedo. Harmonização: o livro definitivo do casamento do vinho com a comida. Rio de Janeiro: Mauad X, 2007.

CALO, Antonio; CERNILLI, Daniele; SABELLICO, Marco. Vinho Manual Do Sommelier. São Paulo:

Editora Globo, 2004

JOHNSON, Hugh. A história do vinho: nova edição ilustrada. [2. ed.]. São Paulo: CMS, 2009.

\section{BIBLIOGRAFIA COMPLEMENTAR:}

ASSOCIATION DE LA SOMMELLERIE INTERNATIONALE (ASI) SOMMELIER: profissão do futuro. 3. ed. [S.I.]: Senac Rio, 2010.

CABRAL, Carlos; MELLO, Carlos Ernesto Cabral de. Presença do vinho no Brasil: um pouco de história.

\begin{tabular}{l} 
2. ed. São Paulo: Cultura, 2007. \\
JOHSON, Hugh; ROBINSON, Jancis. Atlas mundial do vinho. Tradução de Fátima Santos, Renato \\
Rezende, Ricardo Rosenbusch. 6. ed. Rio de Janeiro: Nova Fronteira, 2008. \\
KEEVIL, Susan. Vinhos do mundo todo. Rio de Janeiro:Jorge Zahar, 2006. \\
LOMBARDO, João Alexandre. Santa Catarina à mesa: a revolução das uvas e do vinho e o renascimento \\
das cervejarias no estado. 2. ed. Florianópolis: Expressão, 2009 \\
LONA, Adolfo Alberto. Vinhos e espumantes: degustação, elaboração e serviço. Porto Alegre: Age, 2009. \\
MALNIC,Évelyne; PONTILLO, Odile. Um Só Vinho da Entrada à Sobremesa. São Paulo: Larousse, 2008. \\
\hline 5a FASE \\
Disciplina: SERVIçOS DE RESTAURANTE \\
CARGA HORÁRIA: 72h \\
\hline HABILIDADES \\
Executar serviços de qualidade com domínio de técnica, \\
Funcionamento do setor e utilização de base, nos preceitos de hospitalidade. \\
\hline CONHECIMENTOS: \\
Teorias sobre qualidade na prestação de serviços; \\
Restaurante: tipos, estruturas e funcionamento; \\
Estrutura organizacional, cargos, funções e fluxos de trabalho no setor de serviços de A\&B; \\
Planos, rotinas e fluxos de trabalho; \\
Mise-en-place de sala e de mesa; \\
Etiqueta à mesa; \\
Tipos e técnicas de serviços de sala; \\
Producão em copácambuza; \\
Comunicação e técnicas de venda no restaurante; \\
Controles operacionais e financeiros no setor de serviços; \\
Hospitalidade nos serviços de restaurante. \\
\hline ATITUDES: \\
Respeito; \\
Cooperação; \\
Iniciativa; \\
Interesse e participação; \\
Zelo pelo patrimônio escolar. \\
BIBLIOGRAFIA BÁSICA: \\
CANDIDO, Indio; VIERA, Elenara Vieira de. Gestão de hotéis: técnicas, operações e serviços. Caxias do \\
Sul: Educs, 2003. \\
INSTITUTO DE CULINARIA DA AMERICA. A arte de servir: um guia para conquistar e manter clientes \\
destinado a funcionários, gerentes e proprietários de restaurantes - São Paulo, Rocca, 2004. \\
WALKER, John R. Introdução à hospitalidade. 2 ed. Barueri: Manole, 2002. \\
COMPLEMENTAR: \\
\hline
\end{tabular}


BECK, Heinz. Arte e ciência do serviço. São Paulo: Anhembi Morumbi, 2005.

FONSECA, M. T. Tecnologia gerenciais de restaurantes - 5 ed. São Paulo: Senac, 2009.

MEYER, Dany. Hospitalidade e negócios: o rei da gastronomia de Nova York conta o segredo do

sucesso. São Paulo: Novo Conceito Editora, 2007.

ORNELLAS, Lieselotte H. Alimentação através dos tempos. Florianópolis: UFSC, 2008

SEBESS, Mariana. Técnicas da cozinha profissional. 3 ed. Rio de Janeiro: SENAC, 2010.

ZANELLA, L.C. Manual de Organização de Eventos. Planejamento e operacionalização.3.ed. São Paulo: Atlas, 2006.

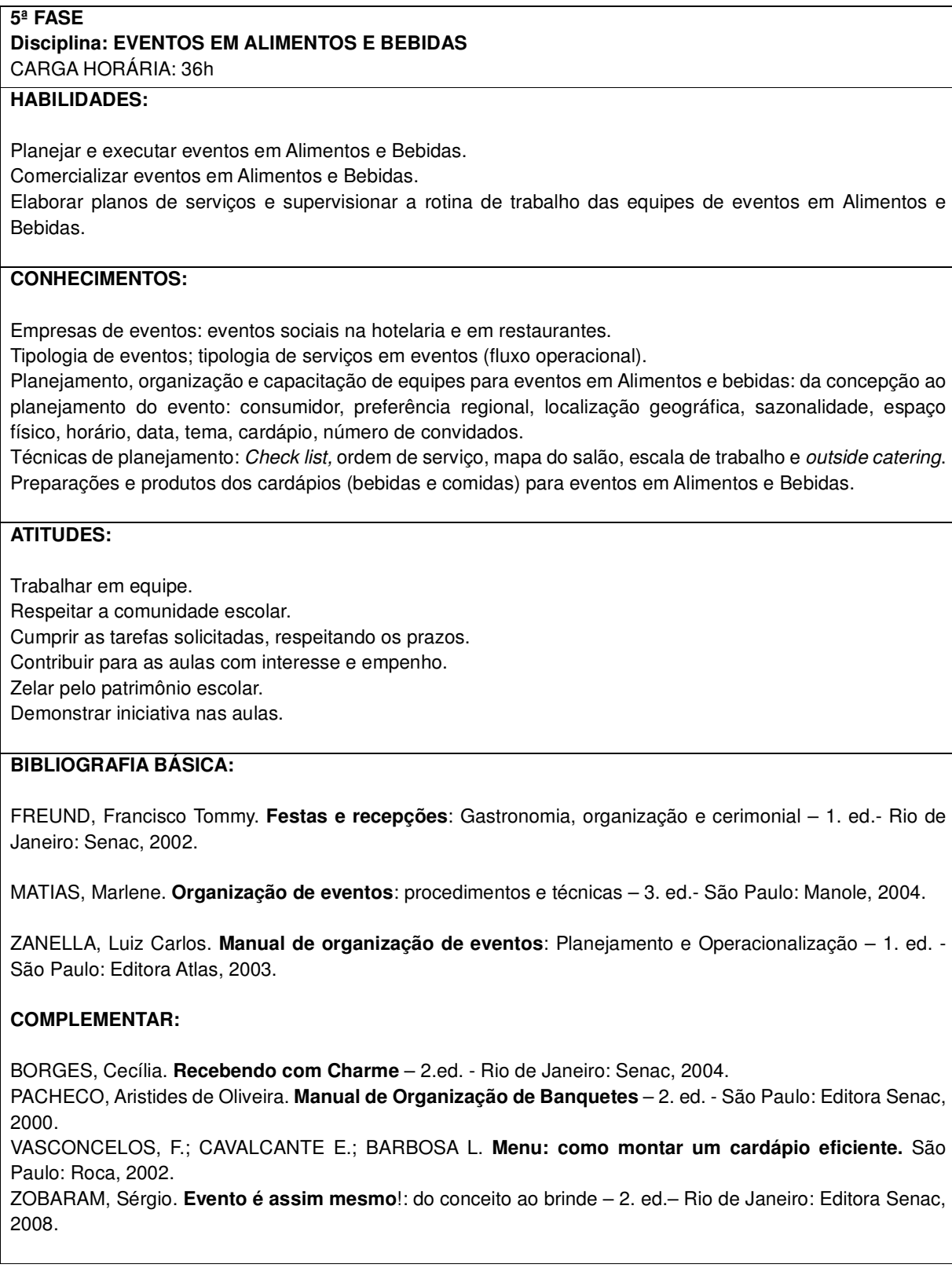




\section{5? FASE}

Disciplina: EMPREEMDEDORISMO

CARGA HORÁRIA: $72 h$

\section{CONHECIMENTOS}

Surgimento do empreendedorismo. Empreendedorismo no Brasil. Diferenças e similaridades entre o administrador e o empreendedor. Características do empreendedor de sucesso. Fatores ambientais e pessoais Processo empreendedor. Os estudos do GEM Global Intrepreneurship Monitor e de mortalidade de empresas do Sebrae. Ideias e oportunidades de negócios. Oportunidades de negócios utilizando a Internet. Fontes de financiamento. Elaboração de plano de negócios e estudo de viabilidade financeira.

Identificar e aplicar os processos necessários para empreender um negócio no âmbito da gastronomia. Elaborar plano de negócios e realizar estudo de viabilidade financeira.

\section{ATITUDES:}

Trabalhar em equipe.

Respeitar a comunidade escolar.

Cumprir as tarefas solicitadas, respeitando os prazos.

Contribuir para as aulas com interesse e empen

Zelar pelo patrimônio escolar.

Demonstrar iniciativa nas aulas.

\section{BIBLIOGRAFIA BÁSICA}

DORNELAS, José Carlos Assis. Empreendedorismo: transformando ideias em negócios. Rio de Janeiro: Elsevier, 2011.

DORNELAS, José Carlos Assis. Empreendedorismo: transformando ideias em negócios. $3^{\text {a }}$ Ed. Rio de Janeiro: Elsevier, 2008.

DAVIS, Bernard et al. Gestão de alimentos e bebidas. Ed. Compacta. (coleção Eduardo Sanovicz de Turismo). Rio de Janeiro: Elsevier, 2012

ZANELLA , Luiz C. Instalação e administração de restaurantes. São Paulo: Metha, 2007.

\section{COMPLEMENTAR}

INSTITUTI EMPREENDER Endeavor. Como fazer uma empresa dar certo em um país incerto: conselhos de 51 dos empreendedores mais bem sucedidos do Brasil. Rio de Janeiro: elsevier, 2005.

LENZI, Fernando César. A nova geração de empreendedores: guia para elaboração de um plano de negócios. São Paulo: Atlas, 2009

DORNELAS, José Carlos Assis. Plano de negócios: seu guia definitivo. Rio de Janeiro: Elsevier, 2011 DOLABELA, Fernando. Oficina do empreendedor: a metodologia de ensino. Rio de Janeiro: Sextante, 2008.

HASHIMOTO, Marcos et al. Práticas de empreendedorismo: casos e plano de negócios. Rio de Janeiro: Campus, 2012

\subsection{Atividades complementares}

Não se aplica.
5.9 Avaliação do Processo Ensino Aprendizagem

A avaliação dar-se-á durante todos os momentos do processo ensino e aprendizagem, valorizando o crescimento do aluno qualitativa e quantitativamente. Em cada disciplina o professor responsável aplicará avaliações pertinentes aos conteúdos teóricos e práticos vistos ao longo do curso.

As avaliações serão organizadas baseadas nos seguintes princípios: a avaliação será diagnóstica, processual, formativa e diversificada. Para além dos conhecimentos e habilidades definidos em cada disciplina, serão considerados como critérios de avaliação as atitudes gerais: trabalhar em equipe; respeitar a comunidade escolar; cumprir as tarefas solicitadas, respeitando os prazos; contribuir para as aulas com interesse e empenho; zelar pelo patrimônio escolar e demonstrar iniciativa nas aulas.

As formas ou tipos de avaliação podem abranger avaliação escrita e/ou oral individual/grupo, apresentação de trabalhos (escrito e oral); avaliações práticas em laboratórios, relatórios, entre outros.

A normatização que se ampara, é ainda denominada de Organização Didático-pedagógica (ODP) do Campus, documento que está sendo reestruturado e será unificado com a denominação de Regimento Didáticopedagógica (RDP). Sendo o presente projeto pedagógico de curso, adaptado assim que definido pelo IFSC.

Ainda de acordo com a Organização Didática da Campus Florianópolis-Continente, a avaliação prima pelo caráter diagnóstico e formativo, consistindo em um conjunto de ações que permitam recolher dados, visando à análise da constituição das competências por parte do aluno, previstas no projeto de curso. Suas funções primordiais são:

a) obter evidências sobre o desenvolvimento do conjunto de conhecimentos, habilidades e atitudes necessárias à constituição de competências, visando à tomada de decisões sobre vrocessos de ensino e aprendizagem e/ou a progrescão do aluno para o semestre seguinte;

b) analisar a consonância do trabalho pedagógico com as finalidades educativas previstas no Projeto Pedagógico do Curso:

c) estabelecer previamente, por unidade curricular, critérios que permitam visualizar os avanços e as dificuldades dos alunos na constituição das competências.

Os critérios servirão de referência para o aluno avaliar sua trajetória e para que o professor tenha indicativos que sustentem tomadas de decisões sobre o encaminhamento dos processos de ensino e aprendizagem e a progressão dos alunos. Os registros das avaliações são feitos de acordo com a nomenclatura que segue:

E - Excelente: quando o aluno ultrapassa as expectativas quanto à aquisição da Competência.

P - Proficiente: quando o aluno supera os parâmetros mínimos requisitados para a construção da competência.

S - Suficiente: quando o aluno atinge os parâmetros mínimos requisitados para a construção da competência. I - Insuficiente: quando o aluno não atinge os requisitos mínimos para a aquisição da competência.

O registro, para fins de documentos acadêmicos, será efetivado ao final de cada módulo, apontando a situação do aluno no que se refere à constituição de competências e utilizando-se a seguinte nomenclatura:

A - (Apto): quando o aluno tiver obtido as competências.

NA - (Não Apto): quando o aluno não tiver obtido as competências.

A partir da avaliação efetuada pelo professor, serão realizadas avaliações coletivas em reuniões que terão o caráter de avaliação integral do processo didático-pedagógico em desenvolvimento na Unidade Curricular. As avaliações coletivas envolverão os professores e os profissionais do núcleo pedagógico. Esses encontros serão realizados, pelo menos, em dois momentos: durante o transcorrer do módulo (com a presença dos 
alunos) e ao final de cada módulo.

Haverá recuperação paralela de conteúdos pela realização de novas atividades pedagógicas no decorrer do período letivo, que possam promover a aprendizagem, tendo em vista o desenvolvimento das competências. Ao final dos estudos de recuperação, o aluno será submetido à avaliação, cujo resultado será registrado pelo professor.

\subsection{Trabalho de Curso}

O trabalho de conclusão de curso (TCC) terá 108 horas sendo desenvolvido na $6^{2}$ Fase, e poderá ser vinculado ao estágio ou não, possibilitando ao aluno optar pelo desenvolvimento de pesquisas aplicadas em áreas distintas ao campo de estágio, mas afim ao curso de Tecnologia em Gastronomia. O aluno poderá optar por realizar concomitantemente ao estágio a pesquisa para o TCC.

A opção de não vincular o TCC ao estágio evidencia a necessidade de trabalhar pesquisas em áreas correlatas tais como, ciências sociais aplicadas, ciências humanas, ciências da saúde, ciências da natureza, entre outras. Existe pouca publicação científica na área de gastronomia e se o campo de pesquisa for mais amplo que as questões problema identificadas junto a empresa concedente de estágio, teremos maiores possibilidades de publicações e um avanço em questões primordiais para a consolidação desta área como ciência.

A orientação seguirá a modalidade presencial e/ ou à distância (quando o aluno estiver impossibilitado de comparecer a orientação presencial), por meio de um cronograma de trabalho e com auxílio de correio eletrônico.

Compete ao professor orientador do trabalho de conclusão de curso orientar o aluno na escolha do referencial teórico apropriado à temática de pesquisa; orientá-lo quanto à metodologia científica do trabalho; seguir o roteiro de apresentação dos resultados; orientar o aluno quanto às normas técnicas de apresentação de roteiro de apresentacios.

Os resultados do trabalho de conclusão de curso (TCC) serão apresentados em forma de artigo científico, de acordo com as normas da ABNT, e serão submetidos a apresentação em banca para apreciação e avaliação de três professores do curso, sendo um deles o professor orientador. Os elementos constituintes de um artigo científico são: título, resumo, palavras-chave, introdução ao tema estudado, justificativa, objetivo, procedimentos metodológicos, referencial teórico, apresentação e análise dos dados, considerações finais e referências.

Os conceitos a serem adotados para aprovação e reprovação constam no item 5.9. Os detalhamentos dos critérios de avaliação do TCC serão construídos pelo NDE a partir do início do curso.

\subsection{Estágios curricular e Acompanhamento do estágio}

O processo de estágio curricular obrigatório para conclusão do Curso Superior de Tecnologia em Gastronomia constitui-se em um instrumento que orienta e normatiza as atividades desenvolvidas pelo/a estagiário/a, considerando que ele/a encontra-se em um período de transição, ou seja, ainda é estudante, mas já é quase um profissional da gastronomia, necessitando traduzir na prática os conhecimentos adquiridos durante seu período de estudos. Nesse contexto, o estágio possibilita a integralização do processo pedagógico no curso de Tecnologia em Gastronomia e tem por finalidade vivenciar a realidade administrativa e operacional por meio do contato direto com a prática profissional.

O estágio previsto dar-se-á segundo a LEI № 11.788, de 25 de setembro de 2008 que dispõe sobre o estágio de estudantes; altera a redação do art. 428 da Consolidação das Leis do Trabalho - CLT, aprovada pelo Decreto-Lei $n-0$ 5.452, de 1 으 de maio de 1943, e a Lei $n \underline{0}$ 9.394, de 20 de dezembro de 1996; revoga as Leis n으 6.494, de 7 de dezembro de 1977, e 8.859, de 23 de março de 1994, o parágrafo único do art. 82 da Le no 9.394, de 20 de dezembro de 1996, e o art. 6 으 da Medida Provisória no $2.164-41$, de 24 de agosto de 2001; e dá outras providências. A normatização que ampara o estágio no IFSC está citada na Organização Didático- pedagógica (ODP) do Campus, documento que será substituído pelo Regulamento Didático-Pedagógico (RDP) do IFSC que está em processo de elaboração e será aprovado ainda em 2014.

Segundo a Lei 11.788 de 25 de setembro de 2008, o estágio é ato educativo escolar, supervisionado, desenvolvido no ambiente de trabalho, que visa à preparação de trabalho produtivo de educandos que estejam frequentando o ensino regular em instituições de educação superior, de educação profissional, de ensino médio da educação especial, dos anos finais do ensino fundamental, na modalidade profissional da educação de jovens e adultos.

O estágio supervisionado e obrigatório para conclusão do curso de Tecnologia em Gastronomia do IFSC tem o objetivo de articular os conhecimentos apreendidos, e as habilidades desenvolvidas no decorrer do curso por meio da prática profissional em empresas conveniadas ao campus Florianópolis Continente do IFSC. estágio acontecerá após a conclusão de $80 \%$ das unidades curriculares anteriores.

Como objetivos do estágio supervisionado e obrigatório:

proporcionar a adequação prática dos conhecimentos recebidos em sala de aula para o exercício - proporcionar a adequação prática dos conhecimentos recebidos da atividade profissional, ligada a gastronomia e hospitalidade;

- favorecer a experiência prática monitorada e supervisionada, facilitando a apropriação do saber-fazer, a construção de competências e o desenvolvimento de habilidades profissionais;

- $\quad$ proporcionar ao/a estudante oportunidades reais para conduzir a uma postura profissional adequada - $\quad$ desenvolver no/a estagiário/a a capacidade criativa na sua área de conhecimento;

O estágio supervisionado e obrigatório para conclusão do curso de Tecnologia em Gastronomia terá uma carga-horária de 252 horas e terá amparo legal no que se refere a quantidade de horas diárias segundo a legislação que o ampara. Ainda conforme a legislação, cada orientador poderá orientar simultaneamente, no máximo, 5 alunos.

As áreas de realização do estágio supervisionado no curso de Tecnologia em Gastronomia são: Gestão de estabelecimentos de Alimentação e Bebidas, Gestão de Alimentos e Bebidas; Produção de alimentos Serviços de Sala e Bar, nos seguintes estabelecimentos: a) empresas de restauração (Alimentos \& Bebidas) públicas e privadas; b) área de Alimentos \& Bebidas nos meios de hospedagem e similares; c) empresas de Catering e Eventos.

As atividades do estágio supervisionado de conclusão do curso de Tecnologia em Gastronomia serão escolhidas no momento da inscrição no setor de estágio do Campus. Os alunos selecionarão o campo de estágio no mercado de trabalho, desde que este esteja inserido em uma das áreas citadas acima e que atenda as ofertas propiciadas pelo IFSC.

Condicionado às ofertas existentes o aluno terá a possibilidade de escolher o seu local de estágio de acordo com a sua área de interesse.

Constituem condições mínimas para uma empresa ser aceita como local para desenvolvimento das atividades do estágio supervisionado estar legalmente constituída e possuir estrutura física, operacional e administrativa que possibilite o desenvolvimento das habilidades práticas apreendidas no decorrer do curso; atuar na área que ofertar 0 estágio supervisionado; dispor de profissionais qualificados para supenvisão das atividades realizadas pelo aluno enquanto estagiário; possuir boa reputação idoneidade moral e legal; apresenta recursos materiais e técnicos que possam ser utilizados pelo estagírio no desenvolvimento do seu trabalho.

Durante a realização do estágio de conclusão do curso de Tecnologia em Gastronomia o aluno terá um supervisor na empresa, que será um profissional capacitado e responsável por ele no local de estágio e um professor orientador. Compete aos docentes orientadores de Estágio: acompanhar o processo de adaptação e as atividades de observação e prática dos/as estagiários/as nos locais de estágio quando possível; realizar um encontro semanal presencial ou a distância (quando o aluno estiver impossibilitado de receber orientação 
presencial) com o estagiário para orientação e supervisão das atividades; manter contato com o/a supervisor/a da empresa concedente e participar de treinamento de qualificação para orientação de estágios.

Compete ao supervisor da empresa concedente: acompanhar o aluno durante a realização do estágio; zelar pelo aluno na empresa; proporcionar um ambiente que possibilite o desenvolvimento das habilidades técnicas no decorrer estágio. Compete ao Professor Orientador acompanhar o aluno no que se refere ao conteúdo técnico e realizar orientação direta ou indiretamente para construção do relatório de estágio. Cabe ao orientador realizar visita in loco para diagnosticar juntamente ao supervisor o andamento das atividades cumpridas pelo aluno.

A avaliação do supervisor da empresa mediante as atividades de estágio do discente, dar-se-á mediante Ficha de Avaliação de Desempenho do Estagiário e deverá constar em anexo ao relatório, alguns dos critérios elencados na ficha são: responsabilidade, interesse, iniciativa, cooperação, assiduidade, conhecimento técnico, dentre outros. A avaliação do orientador dar-se-á mediante a correção do relatório elaborado pelo aluno.

São deveres do estagiário cumprir todas as etapas nos prazos previstos nos programas dos estágios: comparecer a todos os encontros com o/a Supervisor/a Acadêmico/a para orientação; manter a ética profissional no que diz respeito a assuntos sigilosos da empresa e relacionamento interpessoal.

Após a conclusão do estágio o aluno deverá apresentar o relatório das atividades desempenhadas sob a supervisão do professor orientador. O estágio não obrigatório, desenvolvido como atividade opcional no decorrer do curso, seguirá os trâmites previstos na Lei 11.788 de 25 de setembro de 2008 e ficará sob a coordenação de estágio. Ressalta-se que o estágio não obrigatório não contará na carga-horária do curso.

O campus Florianópolis-Continente possui parcerias atuais com estabelecimentos da região, dos quais é possível citar: Supermercado Hippo, Restaurantes do Costão do Santinho, Joy Joy Bistrot, La Boheme Café, Massa Viva, Majestic Hotel, Cachaçaria da ilha, Armazém Vieira, Ponta das Caranhas, Ostradamus, Kampai, Rede Bragança, Alameda Casa Rosa, Rancho Açoriano, Thai, dentre outros.

\section{supervisionadas}

5.12 Prática supervisionada nos serviços ou na indústria, e acompanhamento das práticas Não se aplica.

\subsection{Atendimento ao discente}

atendimento pedagógico e administrativo acontecerá nos turnos de funcionamento do curso. O atendimento por docentes denominado "atendimento extraclasse" está previsto na Resolução 13 do IFSC onde cada docente receberá de 1 a 2 horas semanais para executá-lo. Esse atendimento inclui atividades e programas de nivelamento para alunos. Além disso, o Campus Florianópolis-Continente do IFSC conta com atendimento ao discente por meio do Núcleo Pedagógico formado por equipe interdisciplinar formado pelos seguintes profissionais: uma psicóloga, três pedagogas e uma assistente social. $O$ atendimento ao discente funciona nos três turnos de funcionamento do Campus. No início de cada semestre letivo há divulgação pela equipe pedagógica do local e horário de atendimento aos alunos.

\subsection{Atividades de Tutoria (para cursos EAD)} Não se aplica.

\subsection{Critérios de aproveitamento de conhecimentos e experiências anteriores} Ao matricular-se na respectiva fase, o aluno poderá apresentar requerimento ao respectivo Coordenador de Curso e solicitar aproveitamento de estudos concluídos com êxito por disciplina ou área de conhecimento. Os principais procedimentos observados para análise dos processos de validação das disciplinas, são os seguintes:

Aproveitamento de estudos com base em documentos acadêmicos apresentados pelo aluno, quando for originário de cursos de educação de nível superior.

Reconhecimento de saberes adquiridas, quando o aluno adquiriu as competências e/ou habilidades m cursos de educação profissional em nível básico e técnico, sendo necessária a avaliação do professor da disciplina de reconhecimento de saberes.

\subsection{Avaliação do projeto do curso}

o projeto do curso será avaliado a cada semestre, sendo possivel adequaçōes e aprimoramentos. As propostas serão discutidas em reuniões pedagógicas com docentes do curso, coordenações envolvidas gestores da escola. As reuniões acontecerão periodicamente e constarão no calendário acadêmico. Cabe ao coordenador do curso atender discentes e docentes no que se refere a assuntos relacionados ao curso levá-los a discussão com o núcleo estruturante do curso. O núcleo estruturante realizará reuniões mensais, sempre que tiver pauta a ser discutida, com intuito de ajustar o projeto do curso.

5.17 Incentivo a pesquisa, a extensão e a produção cientifica e tecnológica Para o desenvolvimento e garantia das atividades de pesquisa e extensão ao longo do curso, o curso contará com infraestrutura de laboratórios, equipamentos, corpo docente, transporte e parcerias com empreendimentos da área de atuação ou inter-relacionadas com a atuação do profissional da gastronomia. $O$ desenvolvimento de projetos de pesquisa e extensão serão fomentados pela Instituição com bolsa de pesquisa e extensão para discentes e apoio institucional aos docentes. Os docentes terão a garantia de carga horária no seu plano de atividades para o desenvolvimento de projetos de pesquisa e extensão aprovados pela instituição.

Os professores deste curso também desenvolvem projetos de pesquisa e extensão que são financiados por órgão de fomento externo e que garante a qualidade do trabalho desenvolvido e um aporte adicional de investimentos para estas áreas.

\subsection{Integração (rede pública/licenciatura, rede regional e SUS/saúde, empresas)} Não se aplica. 


\section{CORPO DOCENTE E TUTOTIAL}

6.1 Coordenador do Curso

Costro Júnio

E-mail: deosir@ifsc.edu.br

Telefone: (48) $38778419 /$ (48) 99716684

Titulação: Doutor em Administração e Turismo (UNIVALI)

ormação acadêmica: Graduação em Administração (UFSC)

Regime de trabalho: 40 horas (DE)

Dedicação à coordenação do curso: 25 horas

Possui graduação em Administração (UFSC), Mestrado em Administração (ESAG/UDESC) e Doutorado em Administração e Turismo (UNIVALI).

Foi professor nos Cursos Superiores de Turismo, Administração e suas habilitações: Habilitação em Marketing, Habilitação em Sistemas de Informação, Habilitação em Administração Geral e Habilitação em Comércio Exterior; Comunicação Social habilitação em Publicidade e Propaganda (Faculdade Estácio de Sá) nos anos de 2002 à 2010. Ministrando disciplinas de Teoria Geral da Administração, Tópicos especiais em Administração I e II, Administração Mercadológica I e II, Gestão do Composto Mercadológico I e II, Gestão de Produtos e Serviços, Tópicos Avançados em Administração V, e Marketing Turístico. Coordenador acadêmico e coordenador dos cursos de Administração de 2002 até 2007, Coordenador Curso Superior de tecnologia em Recursos Humanos 2006 até 2007, na Faculdade Estácio de Sá/SC.

Professor e Coordenador do Curso de Administração Habilitação em Marketing, na FACVEST, de 2000 até 2002, ministrando as disciplinas: Teoria Geral da Administração, Administração de Marketing, Administração de Serviços.

Professor convidado em aproximadamente 35 cursos de Pós- graduação, convidado pela IES: Faculdade Estácio de Sá, UNIASSELVI, Faculdades Ação, FGV/ÚNICA e ICPG.

Foi gestor no Banco Real (Gerente e Trainee de gerência); Gestor na Cia e Cervejaria Brahma (Supervisor de Vendas); Coordenador de cursos na Faculdade Estácio de Sá e Coordenador doe curso de Administração habilitação em Marketing FACVEST.

\subsection{Corpo Docent}

Todos os docentes abaixo citados têm regime de trabalho de 40horas/semanais, com dedicação exclusiva.

\begin{tabular}{|c|c|c|}
\hline Nome & $\begin{array}{c}\text { Experiência em } \\
\text { anos no Ensino Su- } \\
\text { perior }\end{array}$ & Titulação \\
\hline \multirow{3}{*}{ Berenice Giehl Zanetti Von Dentez } & \multirow{3}{*}{2,5} & Bacharel em Turismo \\
\hline & & Especialização em Biossegurança \\
\hline & & Mestre em Turismo e Hotelaria \\
\hline \multirow{2}{*}{ Carlos Alberto da Silva Mello } & \multirow{2}{*}{14} & Bacharel em Turismo \\
\hline & & Mestre em Engenharia de Produção \\
\hline \multirow{3}{*}{$\begin{array}{l}\text { Deosir Flávio Lobo de Castro Jú- } \\
\text { nior }\end{array}$} & \multirow{3}{*}{13} & Bacharel em Administração \\
\hline & & Mestre em Administração \\
\hline & & Doutor em Administração e Turismo \\
\hline \multirow{2}{*}{ Donato Marcelo Dreher Heuser } & \multirow{2}{*}{9} & Graduado em Hotelaria \\
\hline & & Mestre em Engenharia de Produção \\
\hline \multirow{3}{*}{ Elinete Eliete de Lima } & \multirow{3}{*}{3,5} & Bacharel em Nutrição \\
\hline & & Especialização em Terapia Nutricional \\
\hline & & Mestre em Nutrição \\
\hline Emilaura Alves & 2,5 & Graduada em Nutrição \\
\hline
\end{tabular}

\begin{tabular}{|c|c|c|}
\hline Nome & $\begin{array}{c}\text { Experiência em } \\
\text { anos no Ensino Su- } \\
\text { perior }\end{array}$ & Titulação \\
\hline & & Mestre em Nutrição \\
\hline \multirow{3}{*}{ Fabiana Mortimer Amaral } & \multirow{3}{*}{4} & Farmácia \\
\hline & & Mestrado em Química \\
\hline & & Doutora em Química \\
\hline \multirow{3}{*}{ Fernando Goulart Rocha } & \multirow{3}{*}{3,5} & Bacharel e Licenciado em Geografia \\
\hline & & Mestre em Geografia \\
\hline & & Doutor em Geografia \\
\hline \multirow{2}{*}{ Flavia Baratieri Losso } & \multirow{2}{*}{3} & Graduada em Turismo e Hotelaria \\
\hline & & Mestre em Turismo e Hotalaria \\
\hline \multirow{2}{*}{ Gládis Teresinha Slonski } & \multirow{2}{*}{1,5} & Bacharel e Licenciada Ciências Biológicas \\
\hline & & Mestre em Biologia Vegetal \\
\hline \multirow{2}{*}{ Gustavo Adolfo Maresch } & \multirow{2}{*}{1,5} & Bacharel em Gastronomia \\
\hline & & Mestre em Turismo \\
\hline \multirow{2}{*}{ Jaqueline de Fátima Cardoso } & \multirow{2}{*}{5} & Graduada em Administração \\
\hline & & Mestre em Administração \\
\hline \multirow{3}{*}{ Jane Parisenti } & \multirow{3}{*}{1,5} & Graduada em Nutrição \\
\hline & & Mestre em Nutrição \\
\hline & & Doutora em Ciências dos Alimentos \\
\hline \multirow{3}{*}{ Krischina Singer Aplevicz } & \multirow{3}{*}{2} & Tecnólogo em Tecnologia em Alimentos \\
\hline & & Bacharel em Administração \\
\hline & & Doutora em Ciência dos Alimentos \\
\hline \multirow{2}{*}{ Liz Cristina Camargo Ribas } & \multirow{2}{*}{1} & Bacharel e Licenciada Ciências Biológicas \\
\hline & & Mestre em Biotecnologia \\
\hline \multirow{2}{*}{ Luciane Patrícia Ogliari } & \multirow{2}{*}{1,5} & Graduada em Enfermagem \\
\hline & & Especialização enfermagem do trabalho \\
\hline \multirow{3}{*}{ Luciano de Azambuja } & \multirow{3}{*}{3} & Graduado em História \\
\hline & & Mestre em Literatura \\
\hline & & Doutor em Geografia \\
\hline \multirow{2}{*}{ Luiz Otávio Cabral } & \multirow{2}{*}{8} & Graduado em Agronomia \\
\hline & & Doutor em Geografia \\
\hline \multirow{3}{*}{ Mariana Ferreira Martelli } & \multirow{3}{*}{3} & Curso Superior de Tecnologia Gastronomia \\
\hline & & Especialização em Gestão em Gastronomia \\
\hline & & Mestre em Turismo e Hotelaria \\
\hline & & Bacharel em Gastronomia \\
\hline Michelle Kormann da Silva & 1,5 & Espec Cozinheiro Chef Internacional \\
\hline & & Mestre em Turismo e Hotelaria \\
\hline Nicole Pelaez & 9 & Bacharel em Gastronomia \\
\hline 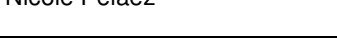 & ( & Mestre em Turismo e Hotelaria \\
\hline Pedró loć Roumundl & 11 & Graduado em Administração \\
\hline rearo sose haymunao & 11 & Mestre em Engenharia da Produção \\
\hline Rofon Matuc Cocto & 1 & Habilitação em Turismo e Hotelaria \\
\hline 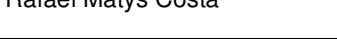 & 1 & Especialização em Gestão de Pessoas \\
\hline
\end{tabular}




\begin{tabular}{|c|c|c|}
\hline Nome & $\begin{array}{c}\text { Experiência em } \\
\text { anos no Ensino Su- } \\
\text { perior }\end{array}$ & Titulação \\
\hline \multirow{2}{*}{ Risolete Maria Hellmann } & \multirow{2}{*}{15} & Graduada em Letras Português-Inglês \\
\hline & & Mestre em Estudos da Linguagem \\
\hline \multirow{3}{*}{ Salete Valer } & \multirow{3}{*}{3} & Bacharel em Letras \\
\hline & & Mestre em Linguística \\
\hline & & Doutora em Linguistica \\
\hline \multirow{3}{*}{ Silvana Graudenz Muller } & \multirow{3}{*}{7} & Tecnólogo em Hotelaria \\
\hline & & Mestrado em Engenharia de Produção \\
\hline & & Doutora Eng e Gestão do Conhecimento \\
\hline \multirow{3}{*}{ Soraya Kobarg Oliveira } & \multirow{3}{*}{10} & Nutricionista \\
\hline & & Especialização em Terapia Nutricional \\
\hline & & Mestre em Ciências dos Alimentos \\
\hline \multirow{2}{*}{ Thiago Henrique Lopes } & \multirow{2}{*}{6} & Tecnologia em gastronomia \\
\hline & & Especialização Docencia no Ensino Superior \\
\hline \multirow{2}{*}{ Vilson de França Goes } & \multirow{2}{*}{0} & Bacharel em Administração \\
\hline & & Especialização Educação Profissional \\
\hline \multirow{3}{*}{ Vinícius de Lucca Filho } & \multirow{3}{*}{6} & Bacharel em Turismo \\
\hline & & Mestre em Tecnologia da Informação \\
\hline & & Doutor em Geografia \\
\hline \multirow{2}{*}{ Wilton Carlos Cordeiro } & \multirow{2}{*}{9} & Nutrição \\
\hline & & Mestrado em Agroecossistema \\
\hline
\end{tabular}

\begin{tabular}{|l|c|c|} 
História da Gastronomia & $36 \mathrm{~h}$ & Luciano Azambuja \\
\hline Habilidades de Cozinha 2 & $72 \mathrm{~h}$ & $\begin{array}{c}\text { Michelle Kormann da Silva } \\
\text { Gustavo Adolfo Maresch }\end{array}$ \\
\hline Panificação e Confeitaria 1 & $72 \mathrm{~h}$ & Krischina Singer Aplevicz \\
\hline Gestão de Pessoas & $36 \mathrm{~h}$ & Deosir Flávio Lobo de Castro Jr \\
\hline Total & $\mathbf{3 6 0 h}$ & \\
\hline
\end{tabular}

A política institucional adotada pelo Campus que prevê capacitação a docentes que buscam elevação de titulação baseia-se na RESOLUÇÃO n 019/2012/CDP de maio de 2012, que aprova as normas para concessão de afastamento para pós-graduação aos servidores do IFSC.

Disciplinas vinculadas aos docentes

\begin{tabular}{|c|c|c|}
\hline \multicolumn{2}{|l|}{$1^{\text {a }}$ Fase } & \multirow[b]{2}{*}{ Docente } \\
\hline Unidades Curriculares & Carga horária & \\
\hline Microbiologia de Alimentos & $36 \mathrm{~h}$ & Krischina Singer Aplevicz \\
\hline Turismo e Hospitalidade & $72 \mathrm{~h}$ & Vinícius De Luca filho \\
\hline Habilidades de Cozinha 1 & $72 \mathrm{~h}$ & Nicole Pelaez \\
\hline Segurança dos Alimentos & $36 \mathrm{~h}$ & Elinete Eliete de Lima \\
\hline Segurança do Trabalho & $36 \mathrm{~h}$ & Luciane Patrícia Ogliari \\
\hline Introdução a Administração & $72 \mathrm{~h}$ & Deosir Flávio Lobo de Castro Jr \\
\hline Fundamentos do Trabalho Acadêmico & $36 \mathrm{~h}$ & $\begin{array}{c}\text { Risolete Maria Hellmann / } \\
\text { Salete Valer }\end{array}$ \\
\hline Total & $360 \mathrm{~h}$ & \\
\hline \multicolumn{2}{|l|}{$2^{\mathrm{a}}$ Fase } & \\
\hline Unidades Curriculares & Carga horária & Docente \\
\hline Tecnologia de Alimentos & $72 \mathrm{~h}$ & Fabiana Mortimer Amaral \\
\hline Sociedade e Trabalho & $36 \mathrm{~h}$ & Fernando Goulart Rocha \\
\hline Gestão da Sustentabilidade & $36 \mathrm{~h}$ & Gládis T. Slonski \\
\hline
\end{tabular}




\begin{tabular}{|l|c|c|}
\hline \multicolumn{1}{|c|}{$3^{\mathbf{a}}$ Fase } & \\
\hline Unidades Curriculares & Carga horária & Docente \\
\hline Análise Sensorial de Alimentos & $36 \mathrm{~h}$ & Soraya Kobarg Oliveira \\
\hline Habilidades de Cozinha 3 & $36 \mathrm{~h}$ & Vilson de França Goes \\
\hline Panificação e Confeitaria 2 & $72 \mathrm{~h}$ & Berenice Ghiehi Zanetti \\
\hline Nutrição e Restrições Alimentares & $72 \mathrm{~h}$ & $\begin{array}{c}\text { Jane Parisenti } \\
\text { Emilaura Alves }\end{array}$ \\
\hline Gestão da segurança de alimentos & $36 \mathrm{~h}$ & Elinete Eliete de Lima \\
\hline Gestão Financeira & $72 \mathrm{~h}$ & Pedro José Raymundo \\
\hline Gestão de Materiais & $36 \mathrm{~h}$ & Jaqueline de Fátima Cardoso \\
\hline Total & $\mathbf{3 6 0 h}$ & \\
\hline
\end{tabular}

\begin{tabular}{|l|c|c|}
\hline \multicolumn{1}{|c|}{$4^{\text {a }}$ Fase } & Carga horária & Docente \\
\hline Gastronomia Clássica (Italiana e Francesa) & $72 \mathrm{~h}$ & Gustavo Adolfo Maresch \\
\hline Gastronomia Brasileira & $72 \mathrm{~h}$ & Silvana Gaudenz Muller \\
\hline Bebidas e Coquetelaria & $72 \mathrm{~h}$ & Wilton Carlos Cordeiro \\
\hline Gestão de Custo & $36 \mathrm{~h}$ & Pedro José Raymundo \\
\hline Gestão de Marketing & $72 \mathrm{~h}$ & Deosir Flávio Lobo de Castro Jr \\
\hline Planejamento de Cardápios & $36 \mathrm{~h}$ & Nicole Pelaez \\
\hline Total & $360 \mathrm{~h}$ & \\
\hline
\end{tabular}

\begin{tabular}{|l|c|c|}
\hline \multicolumn{1}{|c|}{$\mathbf{5}^{\mathbf{a}}$ Fase } & Docente \\
\hline Unidades Curriculares & Carga horária & Liz Cristina Camargo Ribas \\
\hline Ecogastronomia & $36 \mathrm{~h}$ & Michelle Kormann da Silva \\
\hline Gastronomia Contemporânea & $36 \mathrm{~h}$ & Gustavo Adolfo Maresch \\
\hline Gastronomia Internacional & $36 \mathrm{~h}$ & Wilton Carlos Cordeiro \\
\hline Enogastronomia & $72 \mathrm{~h}$ & Donato Marcelo Dreher Heuser \\
\hline Serviços de Restaurante & $72 \mathrm{~h}$ & Flavia Baratieri Losso \\
\hline Eventos em Alimentos e Bebidas & $36 \mathrm{~h}$ & Jaqueline de Fátima Cardoso \\
\hline Empreendedorismo & $72 \mathrm{~h}$ & \\
\hline Total & $\mathbf{3 6 0 h}$ & \\
\hline
\end{tabular}

\begin{tabular}{|l|c|c|}
\hline \multicolumn{2}{|c|}{$6^{\text {a }}$ Fase } & Docente \\
\hline Unidades Curriculares & Carga horária & Todos do curso \\
\hline Trabalho de Conclusão de Curso & $108 \mathrm{~h}$ & Docentes da área técnica \\
\hline Estágio Obrigatório & $252 \mathrm{~h}$ & Uéslei Paterno \\
\hline Libras (optativa) & $72 \mathrm{~h}$ & \\
\hline Total & $360 \mathrm{~h}$ & \\
& $432 \mathrm{~h}$ & \\
\hline
\end{tabular}

\subsection{Corpo Administrativo}

Todos os técnico-administrativos abaixo citados têm regime de trabalho de 40horas/semanais.

\begin{tabular}{|c|c|c|}
\hline Nome & Cargo & Titulação \\
\hline \multirow{2}{*}{ André Dalla Possa } & \multirow{2}{*}{ Assistente Administrativo } & Graduação Comunicação Social \\
\hline & & Mestrado em Sociologia \\
\hline \multirow{2}{*}{ Bruna de Araújo Dechen } & \multirow{2}{*}{ Assistente Administrativo } & Bacharel em Administração \\
\hline & & Bacharel Relações Internacionais \\
\hline \multirow{2}{*}{ Camila Paim Veran } & \multirow{2}{*}{ Assistente Administrativo } & Bacharel em Hotelaria \\
\hline & & Espec. Educação Profissional \\
\hline \multirow[b]{2}{*}{ Carme Rita Borella } & \multirow[b]{2}{*}{ Assistente Administrativo } & Tecnólogo em Eletrônica \\
\hline & & $\begin{array}{l}\text { Especialização Métodos de Melhoria da } \\
\text { Produtividade }\end{array}$ \\
\hline $\begin{array}{l}\text { Caroline Daufemback } \\
\text { Henrique }\end{array}$ & Técnica em Audiovisuais & Designer \\
\hline \multirow{2}{*}{ Cristiane Correa Paulick } & \multirow{2}{*}{ Assistente Administrativo } & Técnica em Eletrotécnica \\
\hline & & Bacharel e Licenciada em História \\
\hline Danielli Prado Dzioba Loss & Técnica em Laboratório & Técnico em Nutrição e Dietética \\
\hline \multirow[b]{2}{*}{ Elizabethe Costa França } & \multirow[b]{2}{*}{ Pedagoga } & Licenciado em Pedagogia \\
\hline & & $\begin{array}{l}\text { Especialização em Gestão e Metodologia } \\
\text { do Ensino }\end{array}$ \\
\hline \multirow{2}{*}{ Fernando Maciel de Miranda } & \multirow{2}{*}{$\begin{array}{l}\text { Técnico de Tecnologia de } \\
\text { Informação }\end{array}$} & Graduação em Administração \\
\hline & & Especialização em Rede de computadores \\
\hline \multirow{2}{*}{ Giuliana F. De Santis } & \multirow{2}{*}{ Técnica em Laboratório } & Técnico em Nutrição \\
\hline & & Curso de Aperfeiçoamento em Nutrição \\
\hline \multirow{2}{*}{$\begin{array}{l}\text { Gleicy Corrêa Nunes } \\
\text { Marques }\end{array}$} & \multirow[b]{2}{*}{ Assistente Administrativo } & Técnica em Eletrotécnica \\
\hline & & $\begin{array}{l}\text { Superior de Tecnologia em Administração } \\
\text { Pública }\end{array}$ \\
\hline Igor Fernandes Kattar & Analista de TI & Ciências da Computação \\
\hline \multirow{3}{*}{ Ivanir Ribeiro } & \multirow{3}{*}{ Psicóloga } & Graduação em Psicologia \\
\hline & & $\begin{array}{l}\text { Especialização na Área da Violência } \\
\text { Doméstica }\end{array}$ \\
\hline & & Mestrado em Educação \\
\hline Jardel Alzemiro Vieira & Técnico de Laboratório & Técnico em Mecânica \\
\hline \multirow{2}{*}{ João Paulo Nunes da Silva } & \multirow{2}{*}{ Assistente Administrativo } & Biologia \\
\hline & & Especialização em Administração \\
\hline
\end{tabular}




\begin{tabular}{|c|c|c|}
\hline Nome & Cargo & Titulação \\
\hline $\begin{array}{l}\text { Jorge Augusto Sandoval } \\
\text { Ferreira }\end{array}$ & Assistente Administrativo & Graduação em Administração \\
\hline \multirow{2}{*}{ José Eduardo Izzo Júnior } & \multirow{2}{*}{ Assistente Administrativo } & Graduação em Direito \\
\hline & & Especialista em Direito Constitucional \\
\hline \multirow{2}{*}{ Josiane Agustini } & \multirow{2}{*}{ Assistente Social } & Bacharel em Serviço Social \\
\hline & & Mestre em Serviço Social \\
\hline \multirow{2}{*}{ Juliana Farias de Lima } & \multirow{2}{*}{ Assistente Administrativo } & Técnica em Meio Ambiente \\
\hline & & Graduação em Geografia \\
\hline \multirow{2}{*}{ Kênia Raupp Coutinho Koch } & \multirow{2}{*}{ Bibliotecária } & Bacharel em Biblioteconomia \\
\hline & & Especialização em Gestão de Informação \\
\hline \multirow{3}{*}{ Letícia Aparecida Martins } & \multirow{3}{*}{ Pedagoga } & Licenciada em Pedagogia \\
\hline & & Especialista em Gestão Pública \\
\hline & & Mestre em Educação \\
\hline \multirow{2}{*}{ Luis Eduardo Lyra } & \multirow{2}{*}{ Assistente Administrativo } & Graduação em Engenharia Mecânica \\
\hline & & Especialização Gestão de Pessoas \\
\hline \multirow[b]{2}{*}{ Luiz Cláudio Soufen Tumolo } & \multirow[b]{2}{*}{ Assistente Administrativo } & Bacharel em Análise de Sistemas \\
\hline & & $\begin{array}{l}\text { Especialização em Administração } \\
\text { Empresas para Executivos }\end{array}$ \\
\hline Luiz Felipe Lindenberg & Assistente Administrativo & Técnico em Segurança do Trabalho \\
\hline \multirow{3}{*}{ Márcia Coghetto Piva } & \multirow{3}{*}{ Assistente Administrativo } & Licenciatura Pedagoga \\
\hline & & Bacharel em Direito \\
\hline & & Especialização em Psicoterapia \\
\hline \multirow{3}{*}{ Meimilany Gelsleichter } & \multirow{3}{*}{ Pedagoga } & Licenciada em Pedagogia \\
\hline & & Bacharel Relações Internacionais \\
\hline & & Especialista Gestão Escolar EJA \\
\hline Milton Makono Toyokawa & Assistente Administrativo & Não possui \\
\hline \multirow{2}{*}{ Morgana Dias Johan } & \multirow{2}{*}{$\begin{array}{l}\text { Técnico em Assuntos } \\
\text { Educacionais }\end{array}$} & Licenciatura em Pedagogia \\
\hline & & Especialização em Educação \\
\hline \multirow{3}{*}{ Nelda Plentz de Oliveira } & \multirow{3}{*}{ Pedagoga } & Licenciada em Pedagogia \\
\hline & & $\begin{array}{l}\text { Especialista em Metodologia do Ensino } \\
\text { Tecnológico }\end{array}$ \\
\hline & & \begin{tabular}{|l|} 
Mestre em Educação \\
\end{tabular} \\
\hline \multirow[b]{2}{*}{ Patrícia da Silva } & \multirow[b]{2}{*}{ Bibliotecária } & Bacharel em Biblioteconomia \\
\hline & & $\begin{array}{l}\text { Especialista em Educação, Currículo e } \\
\text { Cultura }\end{array}$ \\
\hline \multirow{2}{*}{ Paula Bitencourt Neto } & \multirow{2}{*}{ Técnico de Laboratório } & Bacharel em Administração \\
\hline & & Técnica em Cozinha \\
\hline Raquel Franscisco Mafra & Assistente Administrativo & $\begin{array}{l}\text { Licenciatura em Geografia (em } \\
\text { andamento) }\end{array}$ \\
\hline Ricardo Genésio Silvano & Auxiliar Administrtivo & não possui \\
\hline \multirow{3}{*}{ Rosana Kimmel Rodrigues } & & Técnico em Contabilidade \\
\hline & Técnico em Contabilidade & Graduação em Gestão Pública. \\
\hline & & Especialização em Gestão de Pessoas \\
\hline 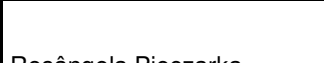 & A cocinto to Adminetrotiva & $\begin{array}{l}\text { Graduada em educação Física e } \\
\text { Fisioterapia. }\end{array}$ \\
\hline Rosangela Pleczarka & Assistente Aaministrativo & $\begin{array}{l}\text { Especialização em Prevenção e } \\
\text { Reabilitação Física }\end{array}$ \\
\hline Ruben Moret Pardo Lima & Engenheiro & Graduação em Engenharia Civil \\
\hline
\end{tabular}

\begin{tabular}{|c|c|c|}
\hline Nome & Cargo & Titulação \\
\hline & & $\begin{array}{l}\text { Especialização em Engenharia e } \\
\text { Segurança no Trab }\end{array}$ \\
\hline \multirow{2}{*}{ Taciany Passos Medeiros } & \multirow{2}{*}{ Técnico de Laboratório } & Técnico em Nutrição e Dietética \\
\hline & & Bacharel em Administração \\
\hline Valéria Aparecida Godoy & Técnico de Laboratório & Bacharel em Ciências dos Alimentos \\
\hline \multirow{2}{*}{ Valéria Matilde dos Santos } & \multirow{2}{*}{ Contadora } & Bacharel em Ciências Contábeis \\
\hline & & Especialização em Gestão Pública \\
\hline \multirow{2}{*}{ Sandra Fátima Lorenzi } & \multirow{2}{*}{ Auxiliar Administrtivo } & Graduada Farmácia \\
\hline & & Especialização Gestão de Pessoas \\
\hline \multirow{2}{*}{ Vanessa Junckes } & \multirow{2}{*}{ Técnica em Laboratório } & Técnica em Nutrição e Dietética \\
\hline & & Graduação em Processos Gerenciais \\
\hline \multirow{2}{*}{$\begin{array}{l}\text { Vanessa Livramento } \\
\text { Garcia }\end{array}$} & \multirow{2}{*}{ Administrador } & Bacharel em Administração. \\
\hline & & Mestre em Administração \\
\hline
\end{tabular}

6.4 Núcleo Docente Estruturante

O núcleo docente estruturante é o responsável pela concepção, acompanhamento, consolidação e avaliação do PPC.

\begin{tabular}{|l|c|c|c|}
\hline \multicolumn{1}{|c|}{ Nome } & $\begin{array}{c}\text { Regime de } \\
\text { trabalho }\end{array}$ & $\begin{array}{c}\text { Carga horária } \\
\text { Atividade NDE }\end{array}$ & Titulação \\
\hline $\begin{array}{l}\text { Deosir Flávio Lobo de Castro } \\
\text { Junior }\end{array}$ & $40 \mathrm{~h}(\mathrm{DE})$ & $\begin{array}{c}25 \mathrm{~h} / \text { semanal } \\
\text { Coordenação }\end{array}$ & Doutor em Administração e Turismo \\
\hline Silvana Graudenz Muller & $40 \mathrm{~h}(\mathrm{DE})$ & $2 \mathrm{~h} /$ semanal & Doutora em Gestão do conhecimento \\
\hline Vinícius De Luca Filho & $40 \mathrm{~h}(\mathrm{DE})$ & $2 \mathrm{~h} /$ semanal & Doutor em Geografia \\
\hline Nicole Pelaez & $40 \mathrm{~h}(\mathrm{DE})$ & $2 \mathrm{~h} /$ semanal & Mestre em Turismo e Hotelaria \\
\hline Soraya Kobarg Oliveira & $40 \mathrm{~h} \mathrm{(DE)}$ & $2 \mathrm{~h} /$ semanal & Mestre em Ciência de Alimentos \\
\hline
\end{tabular}

O colegiado do Curso Superior de Tecnologia em Gastronomia é um órgão consultivo que possu a finalidade acompanhar a implementação do projeto pedagógico, avaliar alterações dos currículos, discutir temas ligados ao curso, planejar e avaliar as atividades acadêmicas do curso.

Sua composição, competência, atribuições e funcionamento é norteada pela deliberação CEPE/IFSC n004, de 05 de abril de 2010 . 


\section{INFRAESTRUTURA FISICA}

\subsection{Instalações gerais e equipamentos}

\begin{tabular}{|c|c|}
\hline AMBIENTE & METRAGEM \\
\hline $\begin{array}{c}\text { Secretaria / Departamento de Desenvolvimento de } \\
\text { Ensino }\end{array}$ & $51,75 \mathrm{~m}^{2}$ \\
\hline Sala da Direção / & $51,75 \mathrm{~m}^{2}$ \\
\hline
\end{tabular}

A secretaria é composta por 3 computadores para uso do registro acadêmico, 3 computadores para uso de alunos, 5telefones sem fio, 1 ar condicionado e equipamento fotocopiadora. $O$ espaço possui janelas para adequada ventilação e iluminação natural. Ailuminação artificial é composta por luzes frias. A chefia de ensino e coordenações possuem gabinetes próprios equipados com computadores.

\subsection{Sala de professores e salas de reuniões}

\begin{tabular}{|c|c|}
\hline AMBIENTE & METRAGEM \\
\hline Sala dos Docentes & $51,75 \mathrm{~m}^{2}$ \\
\hline
\end{tabular}

O espaço para os docentes possui 18 bancadas próprias de trabalho com 6 computadores, ar condicionado armários individuais, equipamento fotocopiadora e mesa redonda para conversar em grupo. O espaço possu janelas para adequada ventilação e iluminação natural. A iluminação artificial é composta por luzes frias.

\begin{tabular}{|l|l|l|}
\multicolumn{2}{c|}{7.3 Salas de aula } \\
\hline Ambiente & Metragem & Equipamentos \\
\hline Sala de Aula & $51,75 \mathrm{~m}^{2}$ & $\begin{array}{l}\text { Projetor multimídia, microcomputador com acesso à } \\
\text { internet, caixas de som, quadro branco, mobiliário } \\
\text { escolar. }\end{array}$ \\
\hline
\end{tabular}

O Campus Florianópolis-Continente possui 7 salas de aula compostas com os equipamentos listados no quadro acima. Não se aplica

7.4 Polos de apoio presencial, se for o caso, ou estrutura multicampi (para cursos EAD)

\subsection{Sala de tutoria (para cursos EAD)}

Não se aplica.

7.6 Suportes midiáticos (para cursos EAD)

Não se aplica.

\subsection{Biblioteca}

7.7.1 Instalações/espaço físico

A biblioteca está atualmente estruturada em $79 \mathrm{~m}^{2}$ e possui acervo bibliográfico específico. $O$ ambiente é ben ventilado, possui 3 computadores para consulta do acervo, assim como mesas coletivas para estudo. Em alteração física da estrutura da biblioteca compreendendo $298 \mathrm{~m}^{2}$, contendo sala de estudos individuais, sala para trabalhos em grupo, guarda volumes e sala de multimeios.

\subsubsection{Equipamentos}

04 - computadores para o setor administrativo da biblioteca:

03 - computadores disponíveis aos usuários para pesquisa e consulta ao acervo;

01 - impressora com scanner;
02 - leitores de código de barras.

\subsubsection{Mobília}

02 - mesas com 4 cadeiras disponíveis aos usuários;

04 - estações de trabalho para a equipe;

02 - armários para uso da biblioteca;

12 - estantes para guarda de livros.

7.7.4 Acervo bibliográfico

Todas obras listadas na bibliografia básica e complementar de cada unidade curricular fazem parte do acervo bibliográfico do Campus. A escola também disponibiliza acesso ao site "Direct Science" possibilitando ao aluno e aos professores consulta a artigos científicos, bem como revistas especializadas na área.

\subsection{Instalações e laboratórios de uso geral e especializados}

O laboratório é reservado para as aulas, para uso de softwares específicos e nos horários disponíveis há acesso para alunos.

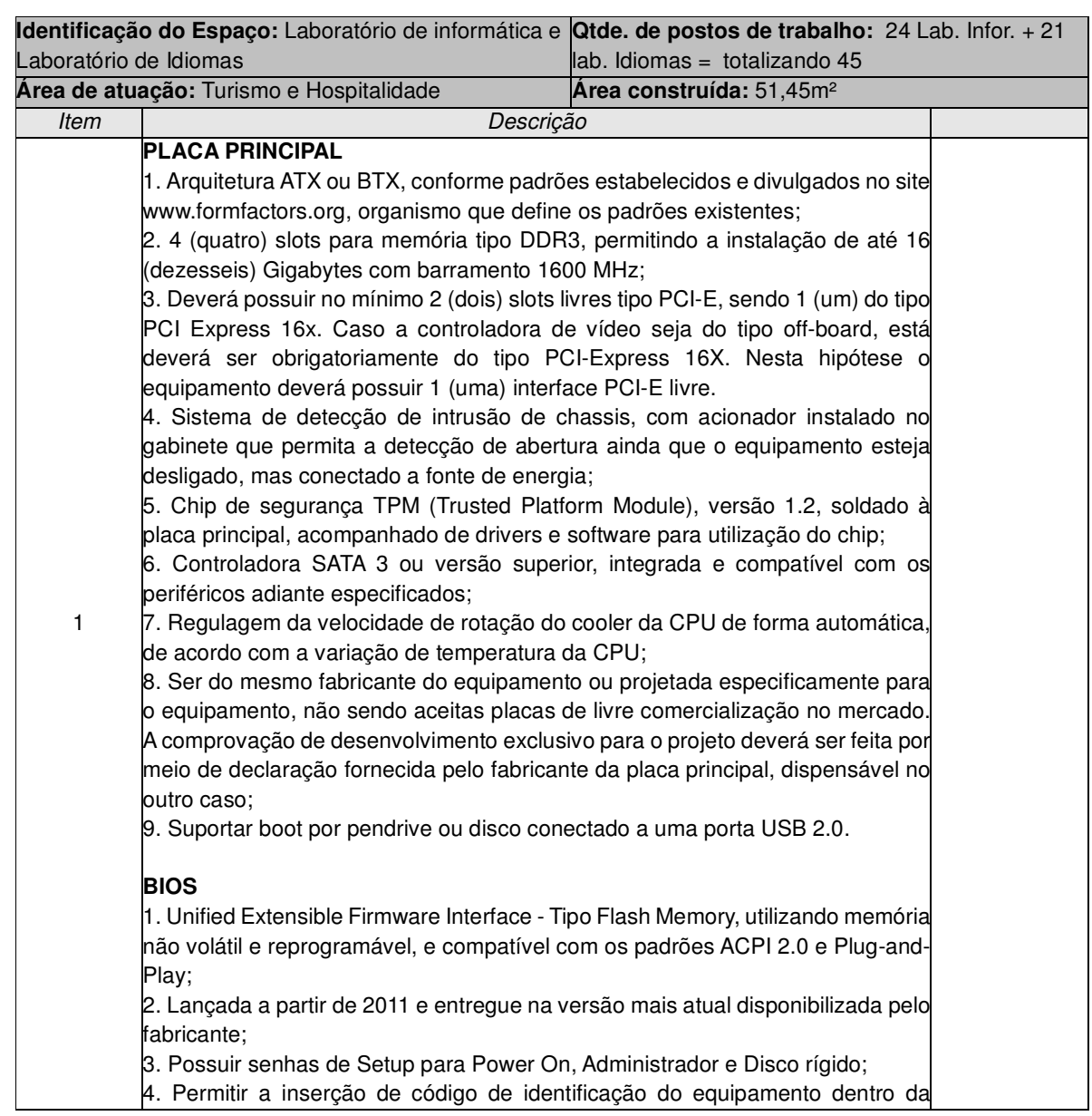




\begin{tabular}{|c|c|}
\hline $\begin{array}{l}\text { entificação do Espaço: Laboratório de informática e } \\
\text { ooratório de Idiomas }\end{array}$ & ab. Infor. +21 \\
\hline 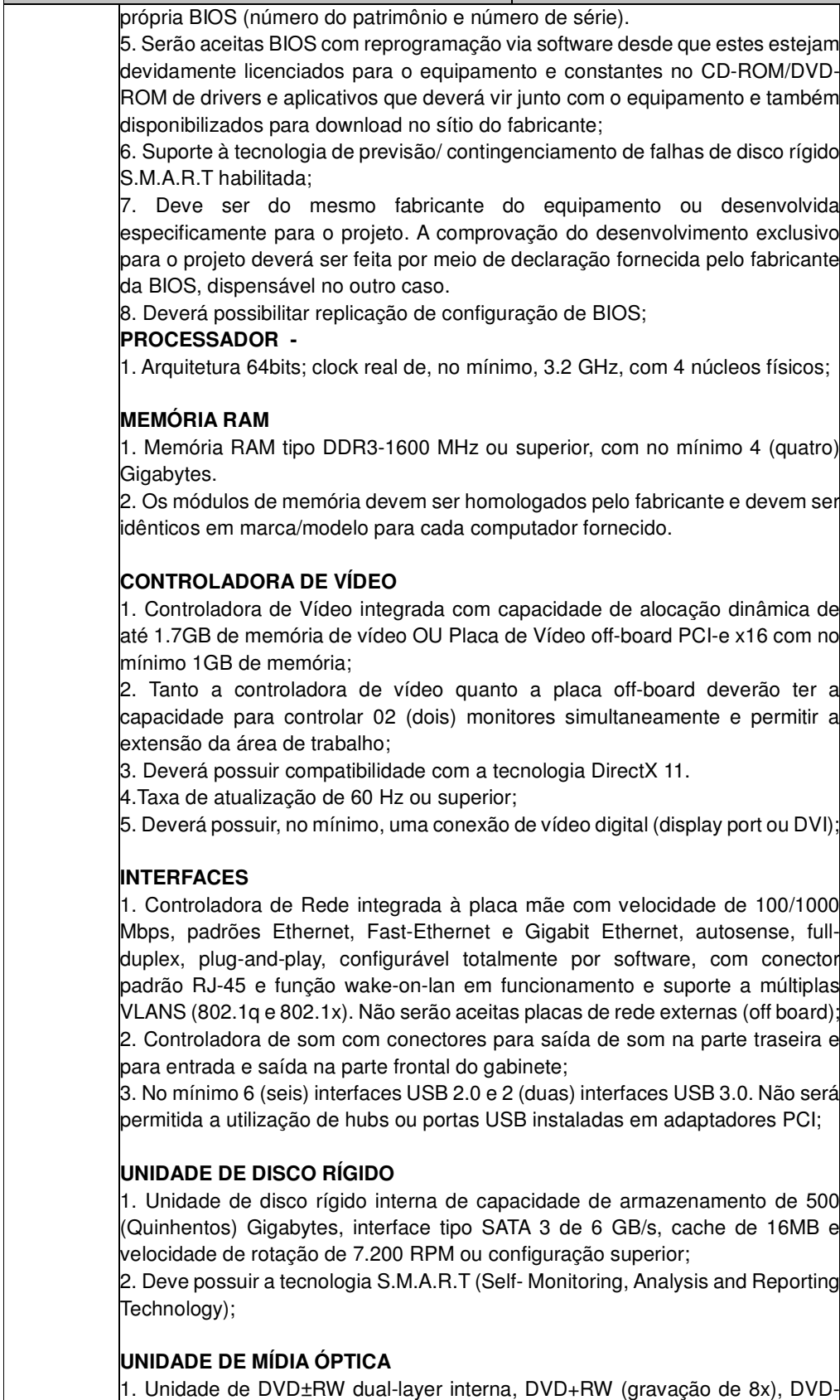 & \\
\hline
\end{tabular}

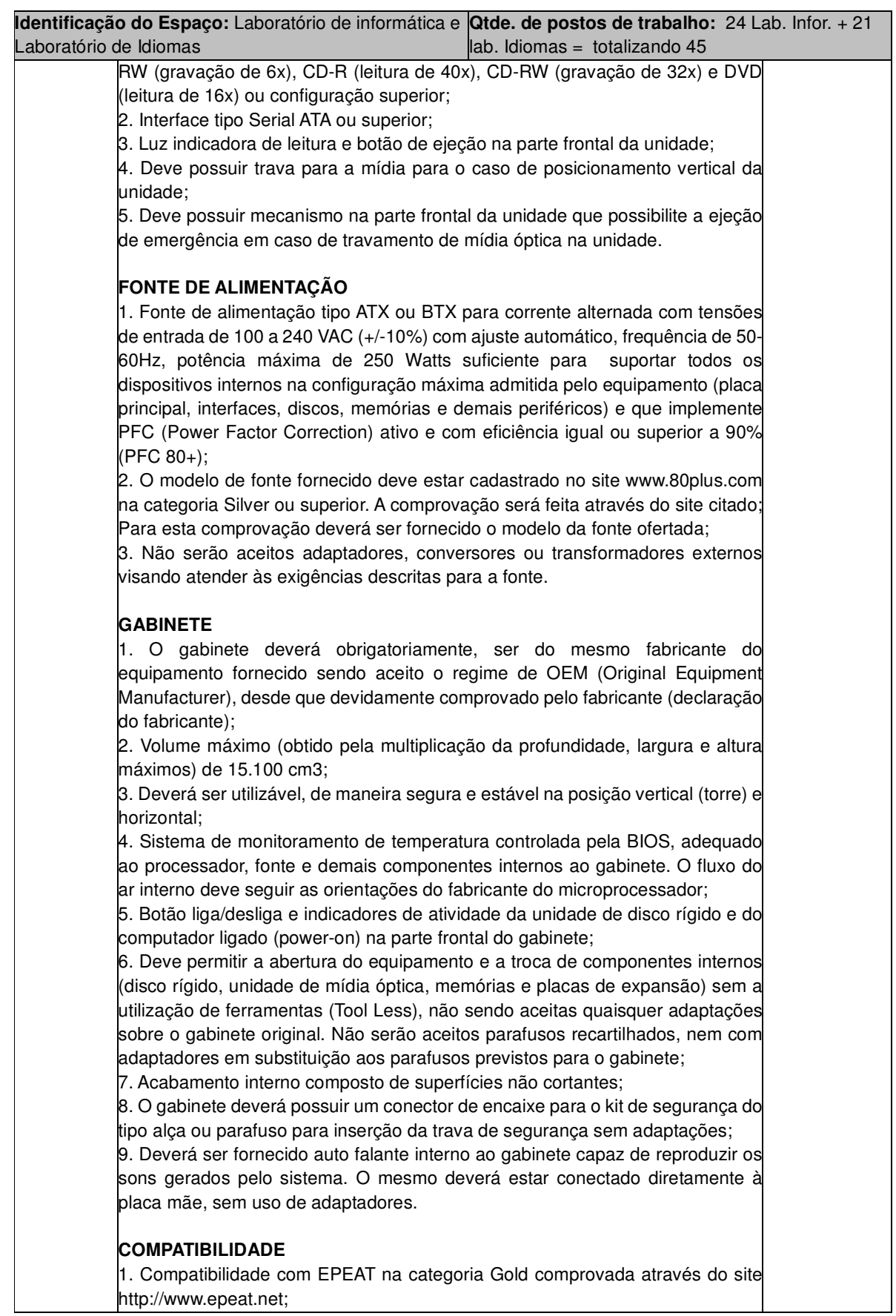




\begin{tabular}{|c|c|}
\hline $\begin{array}{l}\text { entificação do Espaço: Laboratório de informática e } \\
\begin{array}{ll}\text { boratório de Idiomas } & \text { Qtde. de postos de trabalho: } 24 \mathrm{~L} \\
\text { lab. Idiomas = totalizando } 45\end{array}\end{array}$ & Lab. Infor. +21 \\
\hline 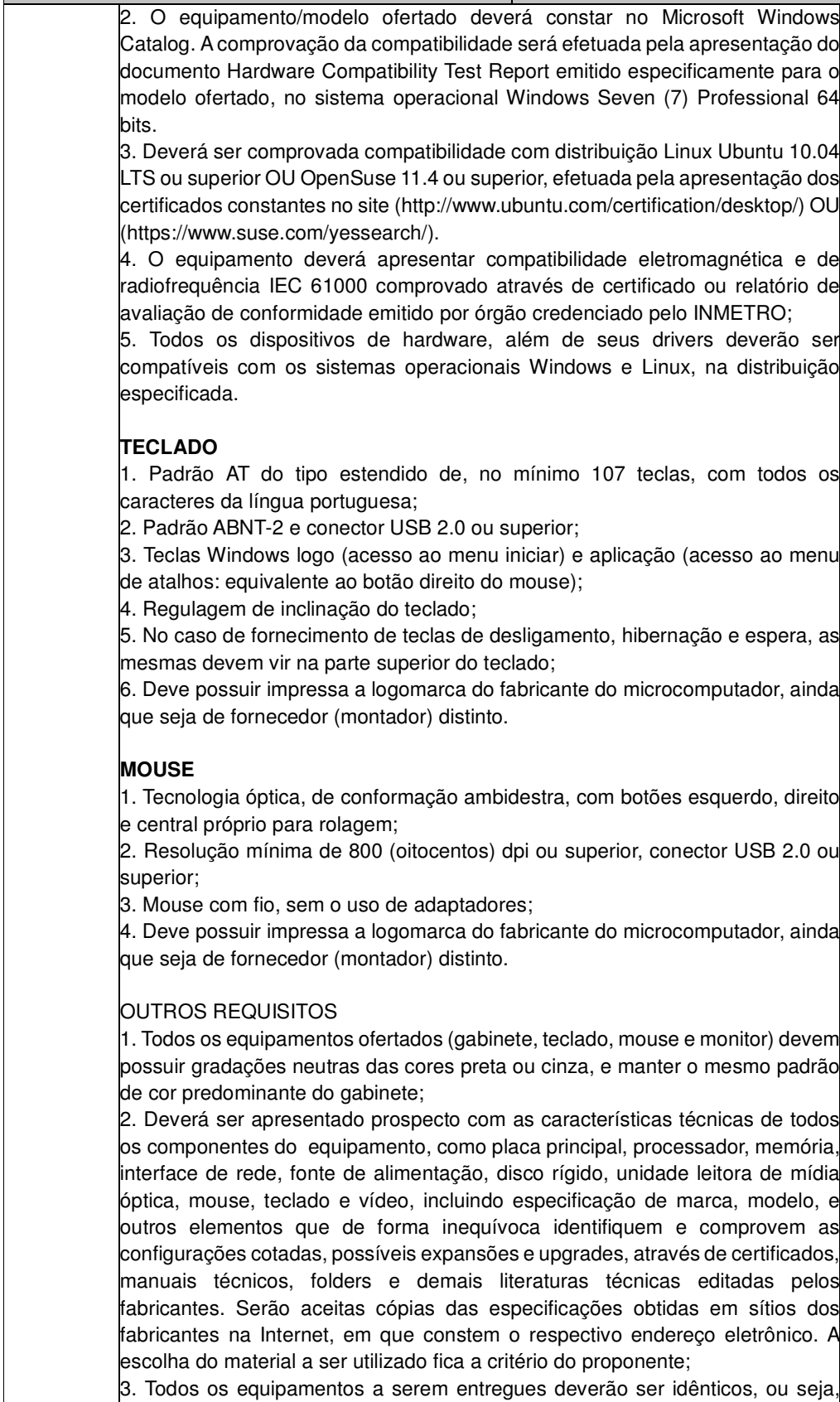 & \\
\hline
\end{tabular}

\begin{tabular}{|c|c|c|}
\hline \multicolumn{3}{|c|}{\begin{tabular}{l|l} 
Identificação do Espaço: Laboratório de informática e e & $\begin{array}{l}\text { Qtde. de postos de trabalho: } 24 \text { Lab. Infor. + } 21 \\
\text { lab. Idiomas = totalizando } 45\end{array}$ \\
$\begin{array}{l}\text { Laboratório de Idiomas }\end{array}$
\end{tabular}} \\
\hline & 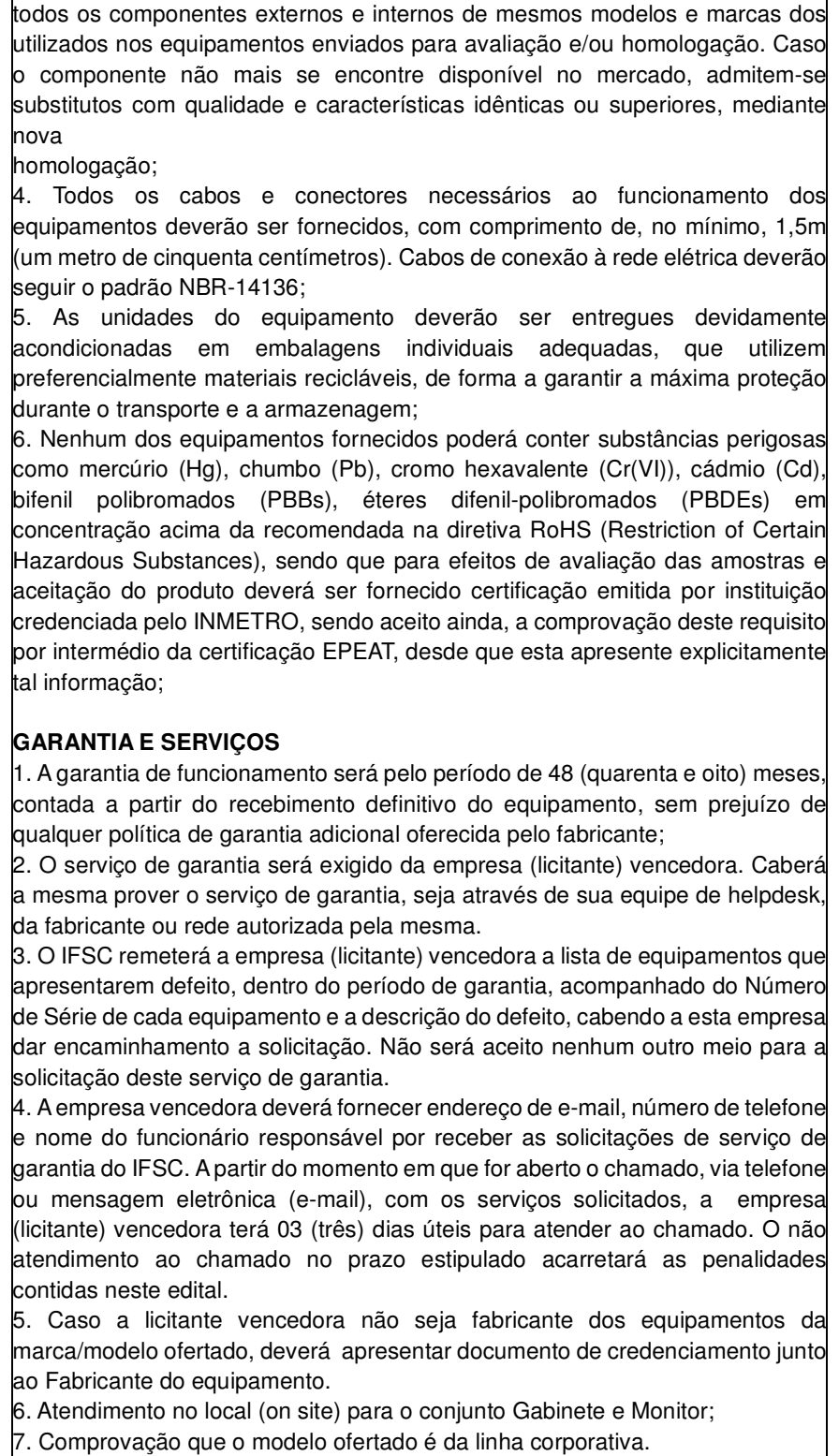 & \\
\hline 2 & $\begin{array}{l}\text { MONITOR DE VÍDEO (Laboratório de Idiomas) } \\
\text { 1. Tela } 100 \% \text { plana de LED, tamanho mínimo de } 18,5^{\prime \prime}, 16.7 \text { Milhões de cores; } \\
\text { 2. Resolução mínima de } 1280 \text { x } 1024 \text { ou } 1920 \text { x } 1080 \text { pixels para cada monitor }\end{array}$ & \\
\hline
\end{tabular}




\begin{tabular}{|c|c|c|}
\hline entif & $\begin{array}{l}\text { do Espaço: Laboratório de informática e } \begin{array}{l}\text { Qtde. de postos de trabalho: } 24 \\
\text { lab. Idiomas = totalizando } 45\end{array}\end{array}$ & Infor. +21 \\
\hline & $\begin{array}{l}\text { que a placa suporte; } \\
\text { 3. Conectores de Entrada: } 01 \text { (uma) entrada VGA e } 01 \text { (uma) entrada DVI ou } \\
\text { DisplayPort; Não serão aceitos adaptadores. } \\
\text { 4. Deverá ser entregue um cabo VGA, } 01 \text { cabo de conexão DVI ou Displayport } \\
\text { e um cabo de alimentação; } \\
\text { 5. Certificação EPEAT no mínimo na categoria Gold comprovada através do site } \\
\text { http://www.epeat.net; } \\
\text { 6. Controle digital de brilho e contraste; } \\
\text { 7. O equipamento deverá apresentar compatibilidade eletromagnética e de } \\
\text { radiofrequência IEC } 61000 \text { comprovado através de certificado ou relatório de } \\
\text { avaliação de conformidade emitido por órgão credenciado pelo INMETRO; } \\
\text { 8. Tela antirreflexiva. Não sendo aceita a solução glare (brilhante ou polida) ou } \\
\text { adesivos } \\
\text { antirreflexivos; } \\
\text { 9. Fonte de Alimentação interna para corrente alternada com tensões de entrada } \\
\text { de } 100 \text { a } 240 \text { VAC (+/-10\%) com ajuste automático, frequência } 50-60 \mathrm{~Hz} ; \\
\text { 10. Os monitores poderão ser de outros fabricantes, fornecidos em regime de } \\
\text { OEM, com a presença da logomarca da empresa fabricante do equipamento } \\
\text { (gabinete), desde que devidamente comprovado pelo fabricante (declaração do } \\
\text { fabricante); } \\
\text { 11. Os fornecedores (licitantes) deverão prestar as garantias dos monitores de } \\
\text { vídeo nos mesmos prazos estipulados para a estação de trabalho propriamente } \\
\text { dita, devendo ser ratificada na proposta comercial, como condição de aprovação } \\
\text { das amostras e da adjudicação. } \\
\text { 12. O equipamento deverá apresentar compatibilidade eletromagnética e de } \\
\text { radiofrequência IEC } 61000 ;\end{array}$ & \\
\hline 3 & $\begin{array}{l}\text { MONITOR DE VIDEO (Laboratório de Informática) } \\
\text { Benq LCD Monitors - T52WA } \\
\text { Screen Size: } 15.4 " \text { Wide } \\
\text { Color: Black } \\
\text { Resolution: } 1280 \times 720(\mathrm{WXGA}) \\
\text { Pixel Pitch: } 0.258 \mathrm{~mm} \\
\text { Brightness: } 200 \mathrm{~cd} / \mathrm{m}^{2} \\
\text { Contrast Ratio: } 400: 1 \\
\text { Response Time: } 8 \mathrm{~ms} \\
\text { Display Area: } 332.16 \times 186.84(\mathrm{~mm}) \\
\text { Color: } 16.7 \text { million } \\
\text { Viewing Angle: } 45 / 45 ; 15 / 35(\mathrm{~L} / \mathrm{R} ; \mathrm{U} / \mathrm{D})(\mathrm{CR}>=10) \\
\text { Input Connector: D-Sub } \\
\text { Horizontal Frequency: } 31-64(\mathrm{KHZ}) \\
\text { Vertical Frequency (Hz): } 56-75(\mathrm{HZ}) \\
\text { Video Bandwidth: } 25-135 \mathrm{MHZ} \\
\text { Color Temperature: } 9300 \mathrm{~K} / 7500 \mathrm{~K} / 6500 \mathrm{~K} / \mathrm{User} \text { Preset } \\
\text { Power Consumption: } 21 \mathrm{~W}(\mathrm{max}) \\
\text { Power Supply: Built-in } \\
\text { Features } \\
\text { 8ms response time } \\
\text { VESA Wall Mounting } 100 \times 100 \mathrm{~mm} \\
\text { TCO'99 } \\
\text { Adjustments: Tilt (Down/Up) }-5 / 20 \\
\text { Accessories (Standard): VGA cable }\end{array}$ & \\
\hline
\end{tabular}

\begin{tabular}{|c|c|c|}
\hline \multicolumn{3}{|c|}{\begin{tabular}{l|l} 
Identificação do Espaço: Laboratório de informática e & $\begin{array}{l}\text { Qtde. de postos de trabalho: } 24 \text { Lab. Infor. + } 21 \\
\text { lab. Idiomas = totalizando } 45\end{array}$ \\
$\begin{array}{l}\text { Laboratório de Idiomas }\end{array}$
\end{tabular}} \\
\hline 4 & 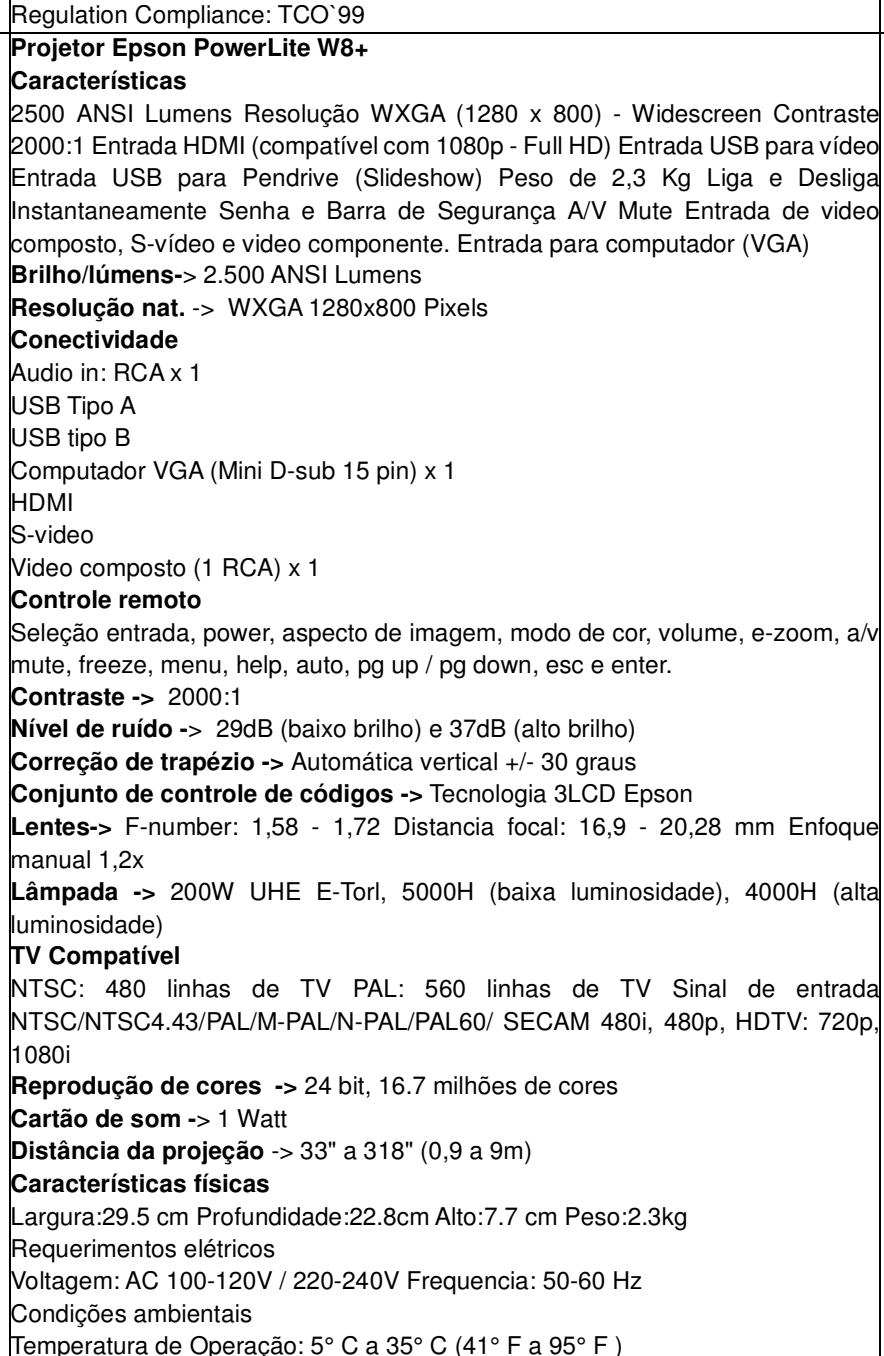 & \\
\hline 5 & $\begin{array}{l}\text { Notebook com processador Intel Celeron M (Tecnologia Centrino), com 1,58 } \\
\text { giga de memória Ram de 512MB DDR2 533MHz, unidade de disco rígido de } \\
60 \mathrm{~GB} \text {, gravador de DVD/CD (8x), placa de FAX MODEN } 56 \text { KBPS, Tela } \\
\text { coloridaSlim com suporte wide screen, anti reflexo e com tamanho 15.4", placa } \\
\text { de vídeo com } 128 \mathrm{MB} \text {, as'da de vídeo externo padrão VGA, } 03 \text { (três portasUSB, } \\
\text { placa de rede 10/100 Mbps, teclado compatível com a língua portuguesa, padrão } \\
\text { ABNTII, comunicação sem fio Wi Fi } 802.11 G \text {, portas PCMCIA, carregador de } \\
\text { bateria, Windows XP-Porfessional - OEM, maleta para transporte. Alimentação } \\
\text { elétrica automática. bateria recarregável de íons de lítio, } 2 \text { horas de duração. } \\
\text { Peso do equipamento completo até } 2,9 \mathrm{~kg} \text {. }\end{array}$ & \\
\hline
\end{tabular}




\subsection{Instalações e laboratórios de uso geral e especializados}

Atualmente o campus dispõem de um laboratório de habilidades de cozinha contendo 18 praças individuais; um laboratório de produção de alimentos com capacidade para 36 alunos; um laboratório de restaurante com capacidade para 40 convidados; dois laboratórios de panificação e confeitaria atendendo 36 alunos; e um laboratório de bebidas contendo 36 lugares.

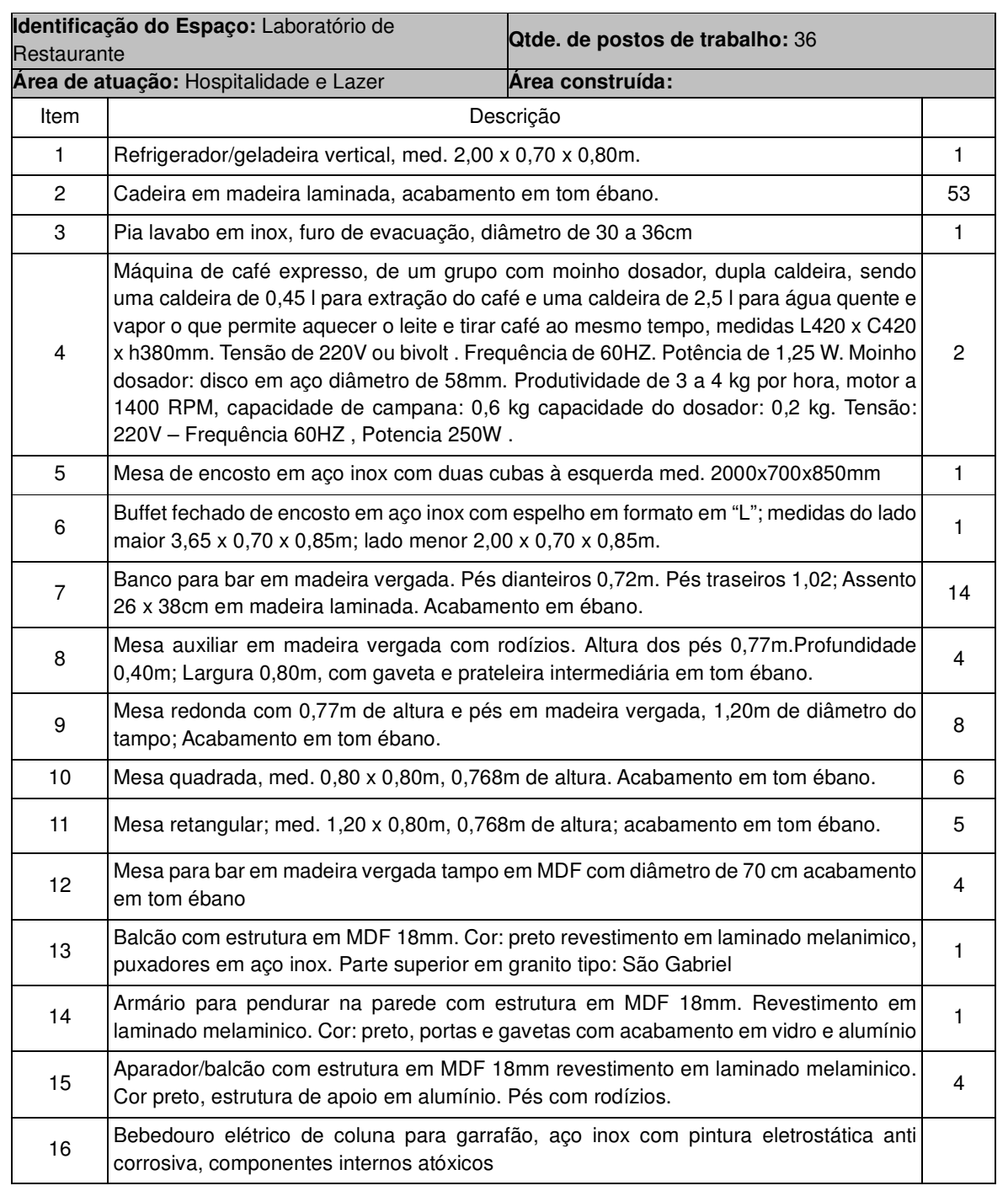

Identificação do Espaço: Laboratório Cambuza Qtde. de postos de trabalho: 18 


\begin{tabular}{|c|c|c|}
\hline \multicolumn{3}{|c|}{ Identificação do Espaço: Laboratório Cambuza } \\
\hline Item & Descrição & Quantidade \\
\hline 1 & Coifa em aço inox, med. 0,68 x 0,68m. & 1 \\
\hline 2 & Prateleira superior lisa, aço inox, mãos francesas; med 1,20 x 0,30cm. & 2 \\
\hline 3 & Cortador/Fatiador de frios automático, desmontável & 1 \\
\hline 4 & $\begin{array}{l}\text { Buffet fechado de centro em aço inox; } 1 / 2 \text { prateleira intermediária, 1/2 armário } \\
\text { com chaves med. } 3,50 \text { × 0,70 × 0,85m. }\end{array}$ & 1 \\
\hline 5 & $\begin{array}{l}\text { Refrigerador doméstico, duplex, duas portas, capacidade minima de refrigeração } \\
3101 \text {, sistema frost free }\end{array}$ & 1 \\
\hline 6 & $\begin{array}{l}\text { Máquina de lavar copos, cap. 1000/1200peças/hora em chapas inox;2,8kw, } \\
220 \mathrm{~V}, 60 \mathrm{~Hz} ; \text { med 0,45 × 0,51 x 0,64m. }\end{array}$ & 1 \\
\hline 7 & $\begin{array}{l}\text { Máquina de gelo em cubo, dimensões } 54 \times 57 \times 110 \mathrm{~cm} \text {, massa } 50 \mathrm{~kg} \text { potencia elé- } \\
\text { trica de } 1 / 3 \mathrm{HP} \text {, fluido refrigerado R-134 e carga de } 190 \mathrm{~g} \text {, nominal } 4,7 \mathrm{~A} \text { e } 220 \mathrm{~V} \text {, } \\
\text { consumo } 630 \mathrm{~W} / \mathrm{h}\end{array}$ & 1 \\
\hline 8 & Buffet fechado em aço inox, med 0,80 x 0,70 ×0,85m. & 1 \\
\hline 9 & $\begin{array}{l}\text { Mesa lisa de centro sem espelho traseiro e com prateleira inferior, med. } \\
0,40 \times 0,40 \times 0,85 \mathrm{~m}\end{array}$ & 1 \\
\hline 10 & $\begin{array}{l}\text { Mesa lisa de encosto em aço inox com espelho traseiro } \\
1 \text { cuba. Med: } 1200 \times 700 \times 850 \mathrm{~mm}\end{array}$ & 1 \\
\hline 11 & Centrífuga industrial de sucos totalmente em inox; potência de $0,5 \mathrm{CV}-220 \mathrm{~V}$. & 1 \\
\hline 12 & $\begin{array}{l}\text { Forno micro-ondas, capacidade entre } 35 \text { e } 40 \mathrm{I} \text {, porta com vidro temperado, timer, } \\
\text { trava de segurança, painel digital } 220 \mathrm{~V}, 60 \mathrm{~Hz} \text {, monofásico }\end{array}$ & 1 \\
\hline 13 & $\begin{array}{l}\text { Balança eletrônica de mesa com capacidade de até } 15 \mathrm{~kg} \text { e divisão de } 5 \mathrm{~g} \text { com } \\
\text { tensão de } 220 \mathrm{~V} \text {. }\end{array}$ & 1 \\
\hline 14 & Espremedor de frutas elétrico, em aço inox $220 \mathrm{~V}$ & 1 \\
\hline 15 & Tostadeira elétrica de pães em aço inox $220 \mathrm{~V}$ & 1 \\
\hline 16 & Fogão a gás de mesa, 2 bocas, med $20 \times 40 \times 6 \mathrm{~cm}$ coleta de residuos & 1 \\
\hline 17 & $\begin{array}{l}\text { Mesa lisa de centro sem espelho traseiro e com prateleira em aço inox med. } \\
100 \times 70 \times 85 \mathrm{~cm}\end{array}$ & 1 \\
\hline 18 & Coifa de aço inox me: $680 \times 680 \mathrm{~mm}$ & 1 \\
\hline 19 & 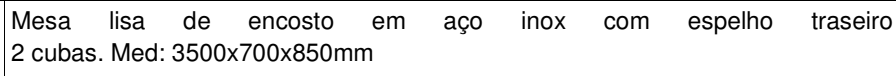 & \\
\hline 20 & $\begin{array}{l}\text { Forno elétrico com fundo de lastro/pedra refratária, camara com regulagem de } \\
\text { temperatura porta em vidro refratario. Med. Aproximadas: } 700 \times 600 \times 250 \mathrm{~mm}\end{array}$ & 1 \\
\hline
\end{tabular}

Identificação do Espaço: Laboratório de Habilidades Básicas de Cozinha

Qtde. de postos de trabalho: 18

Área de atuação: Hospitalidade e Lazer

Área construída: $156,95 \mathrm{~m}^{2}$ Descrição

Liquidificador para cozinha com capacidade de 2 I com estrutura e copo em aço

nox controle com função de velocidades e função pulsar e com tensão de 220B.

Forno micro-ondas, capacidade entre 35 e $40 \mathrm{I}$, porta com vidrc

trava de segurança, painel digital $220 \mathrm{~V}, 60 \mathrm{~Hz}$, monofásico

Resfriador rápido dotado de orifício no fundo para saída de líquidos, isolação térmica com poliuretano injetado de alta densidade $745 \times 790 \times 1.750 \mathrm{~mm}$
Identificação do Espaço: Laboratório de Habilidades

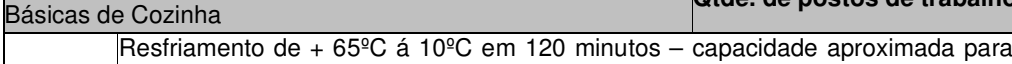

Qtde. de postos de trabalho: 18 20Kg. Congelamento de $+65^{\circ} \mathrm{C}$ à $18^{\circ} \mathrm{em} 240$ minutos - capacidade aprox. para $20 \mathrm{Kg}$.
$10 \mathrm{~kg}$.
Robot

$10 \mathrm{~kg}$. em material atóxico estampado em policarbonato com painel de comando

4 eletrônico. Totalmente fabricado em chapas de aço inoxidável AISI 304 liga 18.10

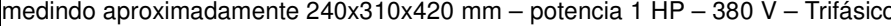
$-60 \mathrm{~Hz}$.

Misturador combinado mixer e batedeira para uso a mão com função batedeira

5 e triturador, monofásico $220 \mathrm{~V}-60 \mathrm{hz}$ com frustra e bastão misturador

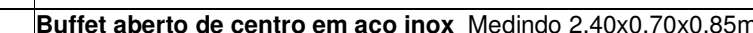

Buffet aberto em aço inox Medindo $1,00 \times 0,70 \times 0,85 \mathrm{~m}$

Buffet aberto em aço inox Medindo 1,00x0,70x0,85m

Buffet aberto em aço inox pés e sapatas de nivelamento em nylon, com espelh

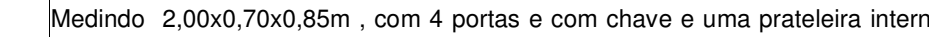
intermediária.

Buffet fechado em aço inox AISI 304 com bitola 22 (e=0,8mm), tampo inox 18

9 liga 18.8 AISI 304 pés e sapatas de nivelamento em nylon, com espelho. Medindo $1,20 \times 0,70 \times 0,85 \mathrm{~m}, \mathrm{com} 2$ portas $\mathrm{com}$ chave e uma prateleira interna intermediári

Balança Analógica de mesa com capacidade de até $5 \mathrm{Kg}$ e divisão $10 \mathrm{~g}$

Fogão a gás de mesa, de sobrepor, com duas bocas, medindo aproximadamente

Fogão a gás de mesa, de sobrepor, com duas bocas, medindo aproximadamente $20 \times 40 \times 6 \mathrm{~cm}$, com os botoes na dimensao da largura, e apoio para coleta $d$ resíduos

12 Pia Lavabo em inox AISI 304 (18/8), espessura 1mm, para montagem mural, com furo de evacuação, com diâmetro de 30 a $36 \mathrm{~cm}$, com furo da torneira em $33 \mathrm{~mm}$.

13 Moedor elétrico de carne

14 Balança de precisão eletrônica de mesa, cap. $15 \mathrm{~kg}$, divisão $5 \mathrm{~g}, 220 \mathrm{~V}$

5 Forno éétrico combinado cinco funcões: vapor, ar seco, banho maria, combinado e regeneração, med. $740 \times 1000 \times 575 \mathrm{~mm}$

16 Serra industrial de de fita para ossos com mesa em aço 220V

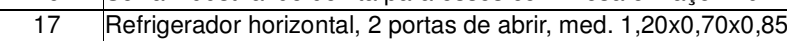

18 Mesa de encosto em aço inox com duas cubas med: $600 \times 500 \times 350 \mathrm{~mm}$

19 Prateleira superior lisa em aço inox med. $1000 \times 300 \mathrm{~mm}$

20 Batedeira planetária de mesa, tacho removível em aço inox 300W de potência com tres tipos de batedores: gancho, globo e palma, $110 \mathrm{~V}, 60 \mathrm{~Hz}$, tomada tripolar, $10 \mathrm{~kg}$ Bebedouro elétrico de pressão, branco 220V

22 Forno elétrico com fundo de lastro/pedra refratária, duas camaras

23 Módulo de cocção acadêmico em aço inox AISI 304. Composição: 3 módulos fogão, 3 módulos pias e 3 módulos de mesas de apoio

Fogão a gás tipo industrial 4 bocas com forno, medidas aproximadas: $80 \times 80 \mathrm{~cm}$

24 Queimadores front simples e traseiros duplos. Corpo em aço inox AISI 304, sapata de nivelamento em nylon.

Chair broiler / Chapa lisa quente em aço inox AISI 304 pedras refratárias de alto

25 poder calorífico no Chair Broiler, bandeja coletora de resíduos e gorduras. Sapatas niveladoras.

Fritadeira em inox 304 medidas aproximadas: $40 \times 80 \mathrm{~cm}$. Tipo água e óleo com capacidade para 18L. Dois cestos fritadores em aço.

Máquina de gelo em cubo, dimensões $54 \times 57 \times 110 \mathrm{~cm}$, massa $50 \mathrm{~kg}$ potencia elétrica

7 de $1 / 3 \mathrm{HP}$, fluido refrigerado $\mathrm{R}-134^{\mathrm{a}}$ e carga de $190 \mathrm{~g}$, nominal $4,7 \mathrm{~A}$ e $220 \mathrm{~V}$, con sumo $630 \mathrm{~W} / \mathrm{h}$

28 Carro para transporte de Gns munidos de kits Gns contendo 3 Gns para ovos, $3 \quad 1$


Identificação do Espaço: Laboratório de Habilidades

Qtde. de postos de trabalho: 18

Cora frituras, 8 Gns esmaltadas 2 Gns tipo grelha frissada teflonada par grelhados.

\begin{tabular}{|c|c|c|}
\hline \multirow{2}{*}{$\begin{array}{l}\text { Identificação do Espaço: Laboratório de } \\
\text { Estoque/Almoxarifado } \\
\text { Área de atuação: Hospitalidade e Lazer }\end{array}$} & \multicolumn{2}{|c|}{ Qtde. de postos de trabalho: 18} \\
\hline & tuação: Hospitalidade e Lazer & \\
\hline Item & Descrição & Quantidade \\
\hline 1 & $\begin{array}{l}\text { Refrigerador doméstico, duplex, duas portas, capacidade mínima de refrigeração } \\
310 \mathrm{l} \text {, sistema frost free }\end{array}$ & \\
\hline 2 & $\begin{array}{l}\text { Balança Plataforma eletrônica com capacidade de } 150 \mathrm{~kg} \text { e divisão } 50 \mathrm{~g} \text { com } \\
\text { tensão de } 220 \mathrm{~V} \text {. }\end{array}$ & 1 \\
\hline 3 & $\begin{array}{l}\text { Balança eletrônica de mesa com capacidade de até } 15 \mathrm{~kg} \text { e divisão de } 5 \mathrm{~g} \text { com } \\
\text { tensão de } 220 \mathrm{~V} \text {. }\end{array}$ & 1 \\
\hline 4 & Balança Analógica de mesa com capacidade de até 5 kg e divisão $10 \mathrm{~g}$. & 1 \\
\hline 5 & $\begin{array}{l}\text { Câmara frigorífica modular com temperatura de trabalho }-25^{\circ} \mathrm{C} \text { a }-15^{\circ} \mathrm{C} \text { com } \\
\text { sensor de controle e visualização de temperatura localizado externamente e com } \\
\text { porta com abertura interna de emergência e sistema de fechamento com chaves } \\
\text { medindo aprox. } 2800 \times 1600 \times 2060 \mathrm{~mm} \text { com tensão elétrica para instalação em } \\
220 \mathrm{~V} \text {. }\end{array}$ & 1 \\
\hline 6 & $\begin{array}{l}\text { Câmara frigorífica modular com temperatura de trabalho }-2^{\circ} \mathrm{C} \text { a }+8^{\circ} \mathrm{C} \text { com sensor } \\
\text { de controle e visualização de temperatura localizado externamente e com porta } \\
\text { com abertura interna de emergência e sistema de fechamento com chaves } \\
\text { medindo aproximadamente } 2800 \times 1600 \times 2060 \mathrm{~mm} \text { com tensão elétrica para } \\
\text { instalação em 220V. Nota Fiscal no } 057 \text { - Empório da Cozinha Industrial Ltda. }\end{array}$ & 1 \\
\hline 7 & Balança Analógica de mesa com capacidade de até $5 \mathrm{Kg}$ e divisão $10 \mathrm{~g}$. & 1 \\
\hline 8 & $\begin{array}{l}\text { Mesa de encosto medindo ( } 120 \times 70 \times 85 \mathrm{~m}) \text { com espelho trazeiro. Tampo inox bitola } \\
18 \text { - liga } 18.8 \text { - aisi } 304 \text {, estrutura em cantoneira de aço inox bitola } 18 \text {, pés em aço } \\
\text { inox diametro } 11 / 2 " \text {, sapatas de nivelamento em nylon, com uma prateleira inferior. }\end{array}$ & 1 \\
\hline 9 & $\begin{array}{l}\text { Carrinho em aço inox AISI } 304 \text {, base em inox bitola } 16 \text { (e=1,5mm), puxador em } \\
\text { tubo aço inox Ø } 11 / 4 ", 4 \text { rodízios de } \varnothing 5 " \text { ", sendo dois giratórios com freios e dois } \\
\text { fixos. }\end{array}$ & 1 \\
\hline 10 & $\begin{array}{l}\text { Carro porta detritos com três rodízios giratórios de } \varnothing 3^{\prime \prime} \text { e freio - em aço } \\
\text { Inoxidável AISI } 304, \text { para } 80 \mathrm{~L} \text {, tampa basculante de pedal, medindo de } 0,43 \text { a } \\
0,57 \mathrm{~m} \text { o diametro e medindo de } 0,63 \text { a } 0,77 \mathrm{~m} \text { a altura. }\end{array}$ & 1 \\
\hline 11 & $\begin{array}{l}\text { Mesa de encosto medindo }(2,00 \times 0,70 \times 0,85 \mathrm{~m}) \text { com espelho trazeiro. Tampo inox } \\
\text { bitola } 18 \text { - liga } 18.8 \text { - aisi } 304 \text {, estrutura em cantoneira de aço inox bitola } 18 \text {, pés } \\
\text { em aço inox diametro } 11 / 2 " \text {, sapatas de nivelamento em nylon, com uma prateleira } \\
\text { inferior. }\end{array}$ & 1 \\
\hline 12 & $\begin{array}{l}\text { Prateleira superior lisa, em aço inox AISI } 304 \text {, bitola } 18 \text { liga } 18.8 \text {, mãos francesas } \\
\text { em aço inox bitola } 14 \text {. Dimensões : } 1,20 \times 0,30 \mathrm{~m}\end{array}$ & 2 \\
\hline 13 & $\begin{array}{l}\text { Buffet aberto em aço inox AISI } 304 \text { com bitola } 22(e=0,8 \mathrm{~mm}) \text {, tampo inox } 18 \text { liga } \\
18.8 \text { AISI } 304 \text { pés e sapatas de nivelamento em nylon, com espelho. Medindo } \\
1,00 \times 0,70 \times 0,85 \mathrm{~m} \text {, com uma gaveta com chave e dispostas no lado esquerdo do } \\
\text { móvel, e uma porta com chave abaixo da gaveta. E uma prateleira intermediária } \\
\text { inferior no restante do móvel. }\end{array}$ & 2 \\
\hline 14 & $\begin{array}{l}\text { Estante lisa perfurada com cinco planos em aço inox bitola 20. Desmostável e } \\
\text { com planos reguláveis. Montantes em aço inóx bitola } 18 \text {. Medindo } \\
0,95 \times 0,35 \times 1,80 \mathrm{~m} 6 \text { prateleiras }\end{array}$ & 3 \\
\hline 15 & $\begin{array}{l}\text { Estante lisa perfurada com três planos em aço inox bitola 20. Desmontável e com } \\
\text { planos reguláveis. Montantes em aço inóx bitola } 18 \text {. Medindo } 1,45 \times 0,54 \times 1,80 \mathrm{~m}\end{array}$ & 1 \\
\hline
\end{tabular}

dentificação do Espaço: Laboratório de

Estoque/Almoxarifado

Qtde. de postos de trabalho: 18

Prateira superior lisa, em aço inox AISI 304, bitola 18 liga 18.8, mãos francesa

16 em aço inox bitola 14. Dimensões : $1,20 \times 0,30 \mathrm{~m}$

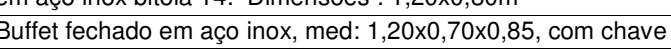

2

Identificação do Espaço: Laboratório de Bebidas e
Enologia

Arologia

\begin{tabular}{|c|c|c|}
\hline \multicolumn{3}{|c|}{ rea de atuação: Turismo e Hospitalidade } \\
\hline Item & Descrição & Quantidade \\
\hline 1 & Buffet fechado em aço inox med. $1,20 \times 0,70 \times 0,85 \mathrm{~m}, 2$ portas com chave & 2 \\
\hline 2 & $\begin{array}{l}\text { Pia lavabo em aço inox, montagem em mural, furo de evacuação, diâmetro de } 30 \\
\text { a } 36 \mathrm{~cm}\end{array}$ & 1 \\
\hline 3 & $\begin{array}{l}\text { Liquidificador capacidade 21, estrutura e copo em inox, controle de velocidade e } \\
\text { pulsar, } 220 \mathrm{~V}\end{array}$ & 1 \\
\hline 4 & Buffet fechado em aço inox; MED. 0,80 X 0,70 X 0,85m & 2 \\
\hline 5 & refrigerador/geladeira duplex & 1 \\
\hline 6 & $\begin{array}{l}\text { Máquina de lavar copos, capacidade } 100 / 1200 \text { peças/hora em chapas inox } \\
28 \mathrm{Kw}, 220 \mathrm{~V}, 60 \mathrm{~Hz} \text {; med. } 0,45 \times 5,109 \times 0,64 \mathrm{~m}\end{array}$ & 1 \\
\hline 7 & $\begin{array}{l}\text { Mesa trapezoidais, med } 1,15 \times 0,65 \mathrm{~m} \text {, tampo aglomerado } \\
\text { revestido em laminado argila, bordas arredondadas }\end{array}$ & 12 \\
\hline 8 & Mesa de encosto em aço inox com 1 cuba med. 1,20 x 0,70 x 0,85m & 1 \\
\hline 9 & Cadeira de madeira laminada, acabamento tom ébano & 23 \\
\hline 10 & $\begin{array}{l}\text { Máquina de gelo em cubo, dimensões } 54 \times 57 \times 110 \mathrm{~cm} \text {, massa } 50 \mathrm{~kg} \text { potencia elé- } \\
\text { trica de } 1 / 3 \mathrm{HP} \text {, fluido refrigerado R-134ª e carga de } 190 \mathrm{~g} \text {, nominal } 4,7 \mathrm{~A} \text { e } 220 \mathrm{~V} \text {, } \\
\text { consumo } 630 \mathrm{~W} / \mathrm{h}\end{array}$ & 1 \\
\hline 11 & $\begin{array}{l}\text { Conjunto de móveis para bar/balcãoe armário MDF } 18 \mathrm{~mm} \text { com revestimento em } \\
\text { fórmica, armário com portas em vidro e lâmpadas dicróicas }\end{array}$ & 1 \\
\hline 12 & $\begin{array}{l}\text { Forno micro-ondas, capacidade entre } 35 \text { e } 40 \mathrm{I} \text {, porta com vidro temperado, timer, } \\
\text { trava de segurança, painel digital } 220 \mathrm{~V}, 60 \mathrm{~Hz} \text {, monofásico }\end{array}$ & 1 \\
\hline 13 & $\begin{array}{l}\text { Banco para bar em madeira vergada, pés dianteiros } 72 \mathrm{~cm} \text { pés traseiros } 102 \mathrm{~cm} \\
\text { assento } 26 \times 38 \mathrm{~cm} \text { em madeira laminada acabamento em tom ébano. }\end{array}$ & 3 \\
\hline 14 & Buffet aberto em aço inox med. $1,00 \times 0,70 \times 0,85 \mathrm{~m}$ & 1 \\
\hline 15 & Armário de aço fechado $2,00 \times 0,4 \times 1,30 \mathrm{~m}$ com 2 portas corrediças & 1 \\
\hline 16 & Mesinha lisa de centro em aço inox med. $55 \times 55 \times 35 \mathrm{~cm}$ & 1 \\
\hline dentific & a̧ão do Espaço: Laboratório de Panificação & \\
\hline irea de $\mathrm{a}$ & tuação: Hospitalidade e Lazer & \\
\hline Item & Descrição & Quantidade \\
\hline 1 & Fogão a gás tipo industrial & 1 \\
\hline 2 & Refrigerador / Geladeira Eletrolux DC - 40 Duplex & 1 \\
\hline 3 & Buffet fechado, em aço inox, med. 0,80x70×0,85m & 1 \\
\hline 4 & $\begin{array}{l}\text { Buffet aberto em aço inox, med. } 1,00 \times 70 \times 0,85 \mathrm{~cm} \text { com } 2 \text { gavetas sobrepostas } \\
\text { dispostas lado esquerdo }\end{array}$ & 2 \\
\hline 5 & $\begin{array}{l}\text { Robot Cutter, profissional, } 70 \mathrm{Db} \text {, dotado de tampa e plano de apoio em material } \\
\text { atóxico, painel de comando eletrônico, med. 240X310x420mm, } 1 \mathrm{HP}, 380 \mathrm{~V} \text {, } \\
\text { trifásico, } 60 \mathrm{HZ}\end{array}$ & 1 \\
\hline 6 & Balança de precisão eletrônica de mesa, cap. 15 kg, divisão $5 \mathrm{~g}, 220 \mathrm{~V}$ & 1 \\
\hline 7 & $\begin{array}{l}\text { Masseira basculante, cap. } 25 \mathrm{~kg} \text { p/ amassar, misturar e sovar massas e embutidos, } \\
\text { med. } 760 \times 630 \times 650 \mathrm{~mm}, 1,5 \mathrm{hp}, 220 \mathrm{~V} \text {, monofásico }\end{array}$ & 1 \\
\hline 8 & Cilindro laminador elétrico, $500 \mathrm{mmdiâmtero,} \mathrm{abertura} \mathrm{rápida} \mathrm{de} \mathrm{espesst}$ & 1 \\
\hline
\end{tabular}




\begin{tabular}{|c|c|c|}
\hline $\begin{array}{l}\text { Identific } \\
\text { Enologic }\end{array}$ & 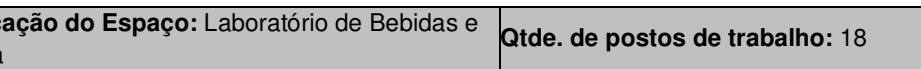 & \\
\hline & $\begin{array}{l}\text { escala graduada que varia } 0,5 \mathrm{~mm} \text { a } 25 \mathrm{~mm} \text { com cilindro de segurança, med. } \\
1340 \times 790 \times 870 \mathrm{~mm}\end{array}$ & \\
\hline 9 & $\begin{array}{l}\text { Modeladora de massas, cap, } 20 \mathrm{~kg} \text {, ditada de esteira e grade dispositivo de } \\
\text { segurança }\end{array}$ & 1 \\
\hline 10 & $\begin{array}{l}\text { Forno estufa para levitação de pães, pintura epoxi, portas e janelas para verificar } \\
\text { crescimento, med. } 2050 \times 455 \times 860 \mathrm{~mm}\end{array}$ & 1 \\
\hline 11 & Buffet fechado em aço inox, med. $2,00 \times 0,70 \times 0,85 \mathrm{~m}, 2$ portas, com chave & 1 \\
\hline 12 & $\begin{array}{l}\text { Buffet fechado em aço inox, med. 2,00×0,70×0,85m, } 2 \text { portas lado esquerdo, lado } \\
\text { direito livre espaço berto livre }\end{array}$ & 1 \\
\hline 13 & $\begin{array}{l}\text { Carrinho aberto com assadeiras, esqueleto de pão doce em aço carbono, contendo } \\
20 \text { assadeiras, med. } 40 \times 60 \mathrm{~cm}\end{array}$ & 1 \\
\hline 14 & $\begin{array}{l}\text { Carrinho fechado com assadeiras, tipo estufa de crescimento de pão, com porta } \\
\text { inteira, com rodizios, com } 20 \text { assadeiras med. } 40 \times 60 \mathrm{~cm} \text { cada }\end{array}$ & 1 \\
\hline 15 & Prateleira superior lisa, aço inox, mãos francesas, med. $120 \times 30 \mathrm{~cm}$ & 1 \\
\hline 16 & $\begin{array}{l}\text { Pia- CGJB, pia lavabo em inox, montagem em mural, furo de evacuação, diâmetro } \\
30 \text { a } 36 \mathrm{~cm}\end{array}$ & 1 \\
\hline 17 & Mesa de encosto em aço inox com duas cubas med: $600 \times 500 \times 350 \mathrm{~mm}$ & 1 \\
\hline 18 & $\begin{array}{l}\text { Coifa de parede em aço inox AISI } 304 \text { com acabamento escovado med. } \\
4000 X 1500 \times 600 \mathrm{~mm} \text {. Duas saídas para dutos de } 400 \mathrm{~mm} \text {. Motores de exaustão } \\
\text { ind. 220V. Chapéu em aço galvanizado. }\end{array}$ & 1 \\
\hline 19 & $\begin{array}{l}\text { Amassadeira semi-rápida. Alimentação: trif́́sica } 380 \mathrm{~V} \text { tacho circular em aço inox. } \\
\text { Garfo de batimento espiral duplo. Capacidade de } 2,5 \mathrm{~kg} \text { a } 45 \mathrm{~kg} \text { de massa. }\end{array}$ & 1 \\
\hline 20 & $\begin{array}{l}\text { Balança de precisão semi análitica resolução/incremento de } 0,001 \mathrm{~g} \text {. Capacidade } \\
\text { máxima de } 500 \mathrm{~g} \text {. Com campânula de vidro móvel com prato em inox }\end{array}$ & 1 \\
\hline 21 & $\begin{array}{l}\text { Batedeira planetária industrial com capacidade para } 20 \mathrm{~L} \text {, corpo em ferro fundido } \\
\text { com pintura epóxi branca tacho e estrutura em batimento em aço inox }\end{array}$ & 1 \\
\hline 22 & $\begin{array}{l}\text { Forno turbo a gás em aço inox porta com vidro duplo temperado, alimentação } \\
\text { trifásico } 380 \mathrm{~V}\end{array}$ & 1 \\
\hline 23 & $\begin{array}{l}\text { Batedeira planetária de mesa, tacho removível em aço inox } 300 \mathrm{~W} \text { de potência com } \\
\text { tres tipos de batedores: gancho, globo e palma, } 110 \mathrm{~V}, 60 \mathrm{~Hz} \text {, tomada tripolar, } 10 \mathrm{~kg}\end{array}$ & 3 \\
\hline 24 & Mesa para manipulação totalmente em aço inox 304 lisa e com prateleira inferior & 2 \\
\hline 25 & $\begin{array}{l}\text { Ultracongelador para resfriamento e congelamento rápido }-30^{\circ} \text { a }-40^{\circ} \mathrm{C} \text {, } \\
\text { produtividade } 15 \mathrm{a} 20 \mathrm{~kg} \text { de congelados e } 20 \text { a } 25 \mathrm{~kg} \text { resfriados por ciclo }\end{array}$ & 1 \\
\hline 26 & $\begin{array}{l}\text { Refrigerador e dosador de água que permite o fornecimento de água gelada } \\
\text { através de termostato. Com dosificador digital e mangueira e torneiras acopladas }\end{array}$ & 1 \\
\hline 27 & $\begin{array}{l}\text { Fatiadeira para pães, serras em aço inox, sendo um lado reto e outro ondulado } \\
\text { cortante. Acabamento de alumínio } 220 \mathrm{~V} \text {, monofásico }\end{array}$ & 1 \\
\hline 28 & $\begin{array}{l}\text { Forno de lastro modular com duas câmaras sobrepostas e independentes. Forno } \\
\text { com pedra refratária. Porta bipartida com vidro temperado } 220 \mathrm{~V} \text { monofásico }\end{array}$ & 1 \\
\hline 29 & $\begin{array}{l}\text { Equipamento para modelagem de pães. Corpo em aluminio fundido ou aço inox, } \\
220 \mathrm{~V} \text {, monofásica }\end{array}$ & 1 \\
\hline 30 & $\begin{array}{l}\text { Misturadeira rápida para massas, tacho e batedor em aço inox, monobloco } \\
\text { temporizador eletrônico peso } 123 \mathrm{~kg}, 220 \mathrm{~V}, 15 \mathrm{~kg} \text { de farinha e } 24 \mathrm{~kg} \text { de massa de } \\
\text { capacidade }\end{array}$ & 1 \\
\hline 31 & $\begin{array}{l}\text { Camara climatizadora para panificação com uma porta, funciona como estufa e } \\
\text { geladeira, painel eletronico para controle de temperatura e umidade } 220 \mathrm{~V} \\
\text { capacidade para } 20 \text { assadeiras }\end{array}$ & 1 \\
\hline 32 & $\begin{array}{l}\text { Forno micro-ondas, capacidade entre } 35 \text { e } 40 \mathrm{I} \text {, porta com vidro temperado, timer, } \\
\text { trava de segurança, painel digital } 220 \mathrm{~V}, 60 \mathrm{~Hz} \text {, monofásico }\end{array}$ & 1 \\
\hline 33 & Freezer vertical tipo doméstico, 1 porta reversivel $260 \mathrm{I}, 220 \mathrm{~V}$ & 1 \\
\hline
\end{tabular}

\begin{tabular}{|c|c|c|}
\hline Identific & ação do Espaço: Laboratório de Confeitaria & \\
\hline Área de & atuação: Hospitalidade e Lazer & \\
\hline Item & Descrição & Quantidade \\
\hline 2 & Fogão a gás tipo industrial & 1 \\
\hline 2 & Refrigerador / Geladeira Eletrolux DC - 40 Duplex & 1 \\
\hline 3 & Buffet fechado, em aço inox, med. 0,80x70x0,85m & 2 \\
\hline 4 & $\begin{array}{l}\text { Buffet aberto em aço inox, med. } 1,00 \times 70 \times 0,85 \mathrm{~cm} \text { com } 2 \text { gavetas sobrepostas } \\
\text { dispostas lado esquerdo }\end{array}$ & 1 \\
\hline 5 & $\begin{array}{l}\text { Robot Cutter, profissional, 70Db, dotado de tampa e plano de apoio em material } \\
\text { atóxico, painel de comando eletrônico, med. 240X310x420mm, } 1 \mathrm{HP}, 380 \mathrm{~V} \text {, trifásico, } \\
60 \mathrm{HZ}\end{array}$ & 1 \\
\hline 6 & Balança de precisão eletrônica de mesa, cap. 15 kg, divisão 5g, 220V & 7 \\
\hline 7 & $\begin{array}{l}\text { Masseira basculante, cap. } 25 \mathrm{~kg} \mathrm{p} / \text { amassar, misturar e sovar massas e embutidos, } \\
\text { med. 760X630x650mm, 1,5hp, 220V, monofásico }\end{array}$ & 1 \\
\hline 8 & $\begin{array}{l}\text { Cilindro laminador de mesa com mesa em aço inox med. Aprox. } 52 \times 50 \times 56 \mathrm{~cm} \text {. Peso } \\
\text { bruto } 57 \mathrm{~kg}, 220 \mathrm{~V}\end{array}$ & 1 \\
\hline 9 & $\begin{array}{l}\text { Modeladora de massas, cap, } 20 \mathrm{~kg} \text {, ditada de esteira e grade dispositivo de } \\
\text { segurança }\end{array}$ & 1 \\
\hline 10 & $\begin{array}{l}\text { Forno estufa para levitação de pães, pintura epoxi, portas e janelas para verificar } \\
\text { crescimento, med. } 2050 \times 455 \times 860 \mathrm{~mm}\end{array}$ & 1 \\
\hline 11 & Buffet fechado em aço inox, med. 2,00×0,70×0,85m, 2 portas, com chave & 1 \\
\hline 12 & $\begin{array}{l}\text { Buffet fechado em aço inox, med. 2,00×0,70×0,85m, } 2 \text { portas lado esquerdo, lado } \\
\text { direito livre espaço aberto livre }\end{array}$ & 1 \\
\hline 13 & $\begin{array}{l}\text { Carrinho aberto com assadeiras, esqueleto de pão doce em aço carbono, contendo } \\
20 \text { assadeiras, med. } 40 \times 60 \mathrm{~cm}\end{array}$ & 1 \\
\hline 14 & $\begin{array}{l}\text { Carrinho fechado com assadeiras, tipo estufa de crescimento de pão, com porta } \\
\text { inteira, com rodizios, com } 20 \text { assadeiras med. } 40 \times 60 \mathrm{~cm} \text { cada }\end{array}$ & 1 \\
\hline 15 & Prateleira superior lisa, aço inox, mãos francesas, med. 120X30 cm & 1 \\
\hline 16 & $\begin{array}{l}\text { Pia- CGJB, pia lavabo em inox, montagem em mural, furo de evacuação, diâmetro } \\
30 \text { a } 36 \mathrm{~cm}\end{array}$ & 1 \\
\hline 17 & Mesa de encosto em aço inox com duas cubas med: $600 \times 500 \times 350 \mathrm{~mm}$ & 1 \\
\hline 18 & $\begin{array}{l}\text { Coifa de parede em aço inox AISI } 304 \text { com acabamento escovado med. } \\
4000 X 1500 x 600 \mathrm{~mm} \text {. Duas saídas para dutos de } 400 \mathrm{~mm} \text {. Motores de exaustão ind. } \\
\text { 220V. Chapéu em aço galvanizado. }\end{array}$ & 1 \\
\hline 19 & $\begin{array}{l}\text { Amassadeira semi-rápida. Alimentação: trifásica } 380 \mathrm{~V} \text { tacho circular em aço inox. } \\
\text { Garfo de batimento espiral duplo. Capacidade de } 2,5 \mathrm{~kg} \text { a } 45 \mathrm{~kg} \text { de massa. }\end{array}$ & 1 \\
\hline 20 & $\begin{array}{l}\text { Balança de precisão semi análitica resolução/incremento de } 0,001 \mathrm{~g} \text {. Capacidade } \\
\text { máxima de } 500 \mathrm{~g} \text {. Com campânula de vidro móvel com prato em inox }\end{array}$ & 1 \\
\hline 21 & $\begin{array}{l}\text { Batedeira planetária industrial com capacidade para } 20 \mathrm{~L} \text {, corpo em ferro fundido com } \\
\text { pintura epóxi branca tacho e estrutura em batimento em aço inox }\end{array}$ & 1 \\
\hline 22 & $\begin{array}{l}\text { Forno turbo a gás em aço inox porta com vidro duplo temperado, alimentação } \\
\text { trifásico } 380 \mathrm{~V}\end{array}$ & 1 \\
\hline 23 & $\begin{array}{l}\text { Batedeira planetária de mesa, tacho removível em aço inox } 300 \mathrm{~W} \text { de potência com } \\
\text { tres tipos de batedores: gancho, globo e palma, } 110 \mathrm{~V}, 60 \mathrm{~Hz} \text {, tomada tripolar, } 10 \mathrm{~kg}\end{array}$ & 4 \\
\hline 24 & Mesa para manipulação totalmente em aço inox 304 lisa e com prateleira inferior & 2 \\
\hline 25 & $\begin{array}{l}\text { Ultracongelador para resfriamento e congelamento rápido }-30^{\circ} \text { a } \quad-40^{\circ} \mathrm{C} \text {, } \\
\text { produtividade } 15 \mathrm{a} 20 \mathrm{~kg} \text { de congelados e } 20 \text { a } 25 \mathrm{~kg} \text { resfriados por ciclo }\end{array}$ & 1 \\
\hline 26 & $\begin{array}{l}\text { Refrigerador e dosador de água que permite o fornecimento de água gelada através } \\
\text { de termostato. Com dosificador digital e mangueira e torneiras acopladas }\end{array}$ & 1 \\
\hline 27 & $\begin{array}{l}\text { Fatiadeira para pães, serras em aço inox, sendo um lado reto e outro ondulado } \\
\text { cortante. Acabamento de alumínio } 220 \mathrm{~V} \text {, monofásico }\end{array}$ & 1 \\
\hline 28 & Forno de lastro modular com duas câmaras sobrepostas e independentes. Forno & \\
\hline
\end{tabular}


Identificação do Espaço: Laboratório de Confeitaria

Qtde. de postos de trabalho: 18 com pedra refratária. Porta bipartida com vidro temperado $220 \mathrm{~V}$ monofásico

29 Equipamento para modelagem de pães. Corpo em aluminio fundido ou aço inox $220 \mathrm{~V}$, monofásica

Misturadeira rápida para massas, tacho e batedor em aço inox, monobloco

temporizador eletrônico peso $123 \mathrm{~kg}, 220 \mathrm{~V}, 15 \mathrm{~kg}$ de farinha e $24 \mathrm{~kg}$ de massa capacidade

Camara climatizadora para panificação com uma porta, funciona como estufa

geladeira, painel eletronico para controle de temperatura e umidade $220 \mathrm{~V}$ capacidade para 20 assadeiras

Forno micro-ondas, capacidade entre 35 e $40 \mathrm{I}$, porta com vidro temperado, timer trava de segurança, painel digital $220 \mathrm{~V}, 60 \mathrm{~Hz}$, monofásico

33 Freezer vertical tipo doméstico, 1 porta reversivel $260 \mathrm{I}, 220 \mathrm{~V}$

34 Fogão cooktop de sobrepor com 3 bocas e 1 placa elétrica com tensão $220 \mathrm{~V}$

Resfriador rápido dotado de orificio no fundo para saida de liquidos, isolação termica

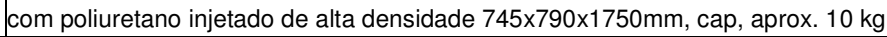
Carrinho fechado com assadeiras, tipo estufa de crescimento de pão, com port inteira com rodizios, com 20 assadeiras med $58 \times 70 \mathrm{~cm}$ cada assadeira

37 Mesa de encosto em aço inox com duas cubas med: 2,00×0,70×0,85m

8 Mesa lisa de centro sem espelho traseiro e com prateleira inferior med $040 \times 0,40 \times 0,85 \mathrm{~m}$

39 Mesinha lisa de centro em aço inox med. $55 \times 55 \times 35 \mathrm{~cm}$

40 Buffet aberto em aço inox com prateleira intermediária encaixe para fogão cookto Balança elétrica comercial capacidade 2,5kg divisão $0,5 \mathrm{~g}$ em plastico ABS injetado Com display 5 digitos em LEDs vermelhos de alta visibilidade 110/220V

Derretedeira de chocolate em aço inox, 2 cubas capacidade total 5I, termostato regulável, $750 \mathrm{~W}$

Laminadora /coratadora de massas com esteira de $800 \mathrm{~mm}$ de comp. Cilindro de laminação em aço inox de $75 \mathrm{~mm}, 1,1 \mathrm{Kw}, 220 \mathrm{~V}, 310 \mathrm{~kg}$, med. 1,1 x2,2x1,25m

Resfriador e dosador de água que permite o fornecimento de agua gelada atraves de termostato. Com dosidificador digital e mangueira e torneiras acopladas.

Cilindro para massas com 2 rolos maciços de $50 \mathrm{~cm}$, superficies atras e na frent Cilindro para massas com 2 rolos maciços
dos cilindros, $220 \mathrm{~V}$, potencia 2,2 a $4 \mathrm{CV}$

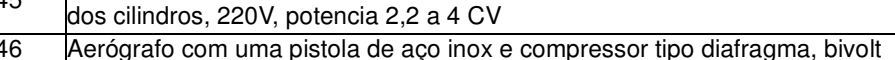

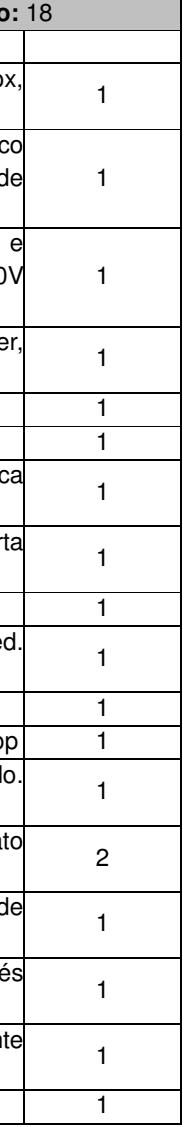

\begin{tabular}{|c|c|c|c|}
\hline \multicolumn{2}{|c|}{$\begin{array}{l}\text { Identificação do Espaço: Laboratório de Produção de } \\
\text { Alimentos }\end{array}$} & \multicolumn{2}{|l|}{ Qtde. de postos de trabalho: 18} \\
\hline \multicolumn{2}{|c|}{ Área de atuação: Hospitalidade e Lazer } & \multicolumn{2}{|l|}{ Área construída: $156,95 \mathrm{~m}^{2}$} \\
\hline Item & Descrição & & Quantidade \\
\hline 1 & $\begin{array}{l}\text { Liquidificador para cozinha com capacidade d } \\
\text { inox controle com função de velocidades e funçã }\end{array}$ & $\begin{array}{l}2 \text { I com estrutura e copo em aço } \\
\text { pulsar e com tensão de } 220 \mathrm{~B} \text {. }\end{array}$ & 2 \\
\hline 2 & Forno microondas com capacidade de aproxim & damente 38 I com tensão de $220 \mathrm{~V}$. & 2 \\
\hline 3 & $\begin{array}{l}\text { Resfriador rápido dotado de orifício no fundo } \\
\text { térmica com poliuretano injetado de alta densida } \\
\text { para apoio de bandejas, porta isolada com } \\
\text { interrupção de funcionamento dos ventiladores, } \\
\text { de comando digital eletrônico e sapatas nive } \\
\text { chapas de aço inox AISI } 304 \text { liga } 18.10 \text { medindo } \\
\text { mm. Resfriamento de }+65^{\circ} \mathrm{C} \text { á } 10^{\circ} \mathrm{C} \text { em } 120 \text { min } \\
\text { 20Kg. Congelamento de }+65^{\circ} \mathrm{C} \text { à } 18^{\circ} \text { em } 240 \mathrm{~m} \\
\mathrm{~kg} \text {. }\end{array}$ & $\begin{array}{l}\text { para saída de líquidos, isolação } \\
\text { e sem uso de CFC, guias e furos } \\
\text { lispositivos de fechamento com } \\
\text { pla velocidade refrigeração, paine } \\
\text { doras. Totalmente fabricado em } \\
\text { aproximadamente } 745 \times 790 \times 1.750 \\
\text { os - capacidade aproximada para } \\
\text { utos - capacidade aprox. para } 10\end{array}$ & 1 \\
\hline 4 & & & \\
\hline
\end{tabular}

Identificação do Espaço: Laboratório de Produção de

Alimentos

em material atóxico estampado em policarbonato com painel de comando eletrônico. Totalmente fabricado em chapas de aço inoxidável AISI 304 liga 18.10 medindo aproximadamente $240 \times 310 \times 420 \mathrm{~mm}$ - potencia $1 \mathrm{HP}-380 \mathrm{~V}$ - Trifásico $-60 \mathrm{~Hz}$.

Misturador combinado mixer e batedeira para uso a mão com função batedeira triturador, monofásico $220 \mathrm{~V}-60 \mathrm{hz}$ com frustra e bastão misturador

Balança Analógica de mesa com capacidade de até $5 \mathrm{Kg}$ e divisão $10 \mathrm{~g}$.

Buffet aberto de centro em aço inox AISI 304 com bitola 22 (e=0,8mm), tampo inox 18 liga 18.8 AISI 304 pés e sapatas de nivelamento em nylon, sem espelho. Medindo $2,40 \times 0,70 \times 0,85 \mathrm{~m}$, com dois postos de trabalho, sendo cada posto de rabalho composto por umacuba, superfíc plana para um fogão duas bocas e uma raballo compo uma supericie de trabaho

6 buffet contem: uma cuba dupla $(0,80 \times 0,50 \times 0,14 \mathrm{~m})$, sendo que essa dupla pode ser duas individuais $(0,40 \times 0,34 \times 0,14 \mathrm{~m})$ dispostas lado lado. Vide desenho. A cuba dupla estará localizada a $0,80 \mathrm{~m}$ da lateral esquerda do tampo e a cuba simples estará localizada a $0,80 \mathrm{~m}$ da lateral direita do tampo. Na parte inferior ao fogão há uma porta com chave, e na parte inferior à superfície de trabalho há uma gaveta com chave e uma prateleira inferior. Em cada cuba, deve estar instalado misturador de parede, com $1 / 4$ de volta, arejador, articulador e mecanismo com vedação cerâmico. Buffet aberto em aço inox AISI 304 com bitola 22 ( $e=0,8 \mathrm{~mm}$ ), tampo inox 18 liga

$7 \quad 18.8$ AISI 304 pés e sapatas de nivelamento em nylon, com espelho. Medindo $1,00 \times 0,70 \times 0,85 \mathrm{~m}$, com uma prateleira inferior intermediária

Buffet aberto em aço inox AISI 304 com bitola $22(e=0,8 \mathrm{~mm})$, tampo inox 18 liga

18.8 AISI 304 pés e sapatas de nivelamento em nylon, com espelho. Medindo $2,00 \times 0,70 \times 0,85 \mathrm{~m}$, com 4 portas e com chave e uma prateleira interna intermediária. Buffet fechado em aço inox AISI 304 com bitola $22(\mathrm{e}=0,8 \mathrm{~mm})$, tampo inox 18 liga

18.8 AISI 304 pés e sapatas de nivelamento em nylon, com espelho. Medindo $0,8 \times 0,70 \times 0,85 \mathrm{~m}$, com 2 portas e com chave e uma prateleira interna intermediária Carro porta detritos com três rodízios giratórios de Ø $3^{\prime \prime}$ e freio - em aço Inoxidáve

10 AISI 304 , para $80 \mathrm{~L}$, tampa basculante de pedal, medindo de 0,43 a $0,57 \mathrm{~m}$ o diametro e medindo de 0,63 a $0,77 \mathrm{~m}$ a altura.

11 Fogão a gás de mesa, de sobrepor, com seis bocas.

12 Pia Lavabo em inox AISI 304 (18/8), espessura 1mm, para montagem mural, co furo de evacuação, com diâmetro de $30 \mathrm{a} 36 \mathrm{~cm}$, com furo da torneira em $33 \mathrm{~mm}$. Fritadeira Elétrica de mesa, Tedesco 40×47×46

Buffet fechado em aço inox AISI 304 com bitola 22 (e=0,8mm), tampo inox 18 liga

418.8 AISI 304 pés e sapatas de nivelamento em nylon, com espelho. Medindo $2,40 \times 1,20 \times 0,85 \mathrm{~m}$, com 2 portas e com chave e uma prateleira interna intermediária

15 Refrigerador horizontal 570 litros, porta com chave

16 Balança de precisão de mesa, cap. $15 \mathrm{Kg}$, divisão $5 \mathrm{~g}$

17 Ḿ́quina de lavar

17 Máquina de lavar copos, cap

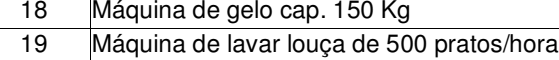

20 Máquina de lavar louça de 810 pratos/hora

21 Forno Elétrico Combinado

22 Armário fechado de aço com 2 portas corrediças

23 Buffet fechado em aço inox $1,50 \times 0,70 \times 0,85 \mathrm{~m}$, com 3 portas e com chave.

24 Buffet

Buffet fechado em aço inox Medindo 2,00x0,70x0,85m, com 2 portas e com

chave.

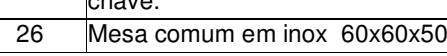

\begin{tabular}{l}
1 \\
\hline 1 \\
1 \\
1 \\
\hline 1 \\
\hline 1 \\
\hline 1 \\
1 \\
1 \\
\hline 1 \\
\hline
\end{tabular}




\begin{tabular}{|c|c|c|}
\hline $\begin{array}{l}\text { Identif } \\
\text { Aliment }\end{array}$ & ação do Espaço: Laboratório de Produção de & \\
\hline 27 & Refrigedaror com duas portas e uma prateleira $1,50 \times 0,70 \times 0,8 \mathrm{~m}$ & 1 \\
\hline 28 & Refrigedaror com duas portas e uma prateleira $1,20 \times 0,70 \times 0,8 \mathrm{~m}$ & 1 \\
\hline 29 & Refrigedaror com três portas e uma prateleira $2,00 \times 0,70 \times 0,8 \mathrm{~m}$ & \\
\hline 30 & Mesa de centro em aço inox $120 \times 115 \times 85 \mathrm{~cm}$ & 1 \\
\hline 31 & Mesa de encosto em aço inox $60 \times 70 \times 85 \mathrm{~cm}$ & 1 \\
\hline 32 & Mesa lisa com espelho traseiro e prateleira inferior $190 \times 70 \times 85 \mathrm{~cm}$ & \\
\hline 33 & Pia lavabo em inox com furo de evacuação $d=30$ à $36 \mathrm{~cm}$ & 2 \\
\hline 34 & Mesa de encosto com uma cuba em aço inox $1,20 \times 0,70 \times 0,85 \mathrm{~m}$ & 5 \\
\hline 35 & $\begin{array}{l}\text { Buffet de distribuição em aço inox com aquecimento interno com termostato } \\
\text { eletrônico } 2800 \times 850 \times 700 \mathrm{~mm}\end{array}$ & 1 \\
\hline 36 & Mesa de encosto em aço inox com duas cubas $600 \times 500 \times 350 \mathrm{~mm}$ & 1 \\
\hline 37 & Bebedouro elétrico de pressão branco & 1 \\
\hline 38 & Coifa em aço inox & 1 \\
\hline 39 & Fogão 4 bocas com forno $80 \times 80 \mathrm{~cm}$ & 2 \\
\hline 40 & Char broiler em inox com pedras refratárias, grelhas e chapa bipartida. & 1 \\
\hline 41 & Fritadeira em inox 40x80 cm. Capacidade 18 litros com dois cestos. & 1 \\
\hline 42 & $\begin{array}{l}\text { Cozedor de massa } 40 \times 80 \mathrm{~cm} \text {. Capaidade } 18 \text { litros com seis cestos pequenos e um } \\
\text { cesto grande }\end{array}$ & 1 \\
\hline 43 & Chapa quente $40 \times 80 \mathrm{~cm}$. & 2 \\
\hline 44 & Centrífuga industrial de sucos & 1 \\
\hline 45 & Pass through aquecido com duas portas e seis pares para engavetamento de GN & 1 \\
\hline 46 & Pass through refrigerado com duas portas e seis pares para engavetamento de GN & 1 \\
\hline
\end{tabular}

\section{REFERÊNCIAS}

ABRASEL - Associação Brasileira de Bares e Restaurantes. Disponível em: http://www.abrasel.com.br/. Acesso em 03/08/2012.

ALBAN, M. Turismo no Brasil: a estratégia de expansão espacial e seus problemas. Turismo Visão e Ação (2): 301-308, 2006.

BRASIL Missão institucional. Ministério do Turismo, Brasília. Disponível em: http://www.turismo.gov.br Acesso em 2011.

DONATO, Dalton R. Restaurante por quilo: uma área a ser abordada. São Paulo: Matha, 2009.

IBGE. Pesquisa Nacional por Amostra de Domicílios (PNAD). IBGE, Rio de Janeiro, 1999.

INSTITUTO BRASILEIRO DE GEOGRAFIA E ESTATÍSTICA. Economia do turismo: uma perspectiva macroeconômica 2000-2005. Rio de Janeiro: IBGE, 2008

IFSC. Relatório final da pesquisa de mercado com profissionais do setor de restaurantes, bares, lanchonetes, confeitarias e panificadoras, na região da Grande Florianópolis. Centro Federal de Educação Tecnológica de Santa Catarina, Florianópolis, 2009.

OLIVEIRA, J. ; PINHEIRO, M. \& GAIO, C. Análise da organização do turismo em Florianópolis. Turismo Visão e Ação (9): 51-60, 2002.

ROCHA, J. \& ALMEIDA, N de P. Políticas públicas federais de turismo: uma análise do Plano Nacional de Turismo 2003-2007 (Brasil). Turismo e Sociedade (2): 105-116, 2008

SANCHO, A. Introdução ao turismo. Traduzido por Dolores Martin Corner. São Paulo: Roca, 2001. 